Wildlife Program

Prepared in cooperation with the U.S. Navy

\title{
Kelp Forest Monitoring at Naval Base Ventura County, San Nicolas Island, California: Fall 2019, Sixth Annual Report
}

Open-File Report 2021-1081 
Cover: Macrocystis pyrifera at East Dutch Harbor, San Nicolas Island, California.

Photograph by Michael Kenner, U.S. Geological Survey, November 7, 2012. 


\section{Kelp Forest Monitoring at Naval Base Ventura County, San Nicolas Island, California: Fall 2019, Sixth Annual Report}

By Michael C. Kenner and Joseph Tomoleoni

Wildlife Program

Prepared in cooperation with the U.S. Navy

Open-File Report 2021-1081 


\section{U.S. Geological Survey, Reston, Virginia: 2021}

For more information on the USGS - the Federal source for science about the Earth, its natural and living resources, natural hazards, and the environment—visit https://www.usgs.gov or call 1-888-ASK-USGS.

For an overview of USGS information products, including maps, imagery, and publications, visit https://store.usgs.gov/.

Any use of trade, firm, or product names is for descriptive purposes only and does not imply endorsement by the U.S. Government.

Although this information product, for the most part, is in the public domain, it also may contain copyrighted materials as noted in the text. Permission to reproduce copyrighted items must be secured from the copyright owner.

Suggested citation:

Kenner, M.C., and Tomoleoni, J., 2021, Kelp forest monitoring at Naval Base Ventura County, San Nicolas Island, California-Fall 2019, sixth annual report: U.S. Geological Survey Open-File Report 2021-1081, 97 p., https://doi.org/10.3133/ofr20211081.

ISSN 2331-1258 (online) 


\section{Acknowledgments}

We would like to thank the U.S. Navy for funding and facilitating this research project. We thank the following U.S. Geological Survey employees: Julie Yee for her support and efforts to keep the project going, Kevin Lafferty for reviewing an earlier draft of this report, and divers George Esslinger and Keith Miles for contributing their time and skills. Long-time volunteer divers Ken Collins and Shannon Myers again contributed hard work and good spirits. We also would like to thank Shawn Larson, of the Seattle Aquarium, for her constructive comments on the draft report, as well as the captain and crew of the Magician for keeping us safe and comfortable. For access to data, please contact Joseph Tomoleoni at jtomoleoni@usgs.gov. 



\section{Contents}

Acknowledgments ……...................................................................................................................

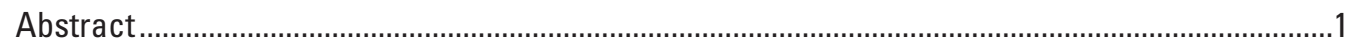

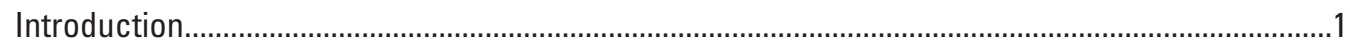

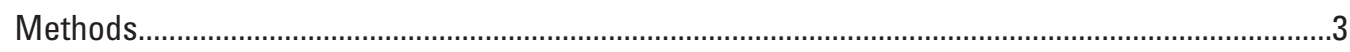

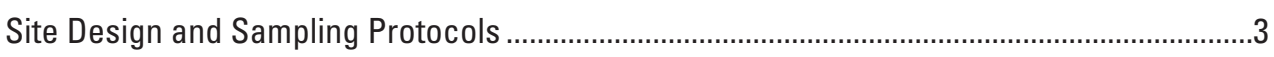

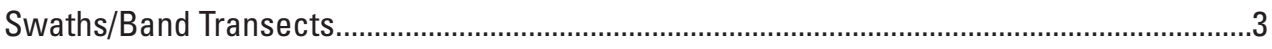

Random Point Contact Sampling .........................................................................................

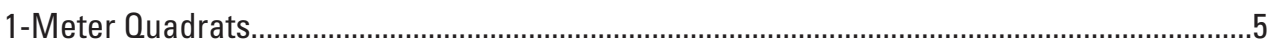

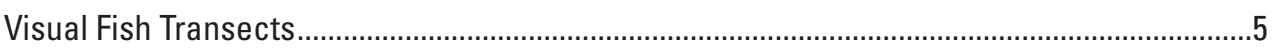

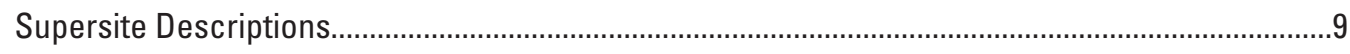

Nav Fac 100

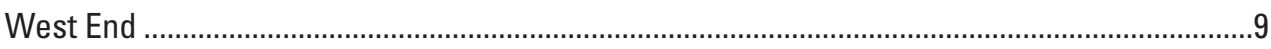

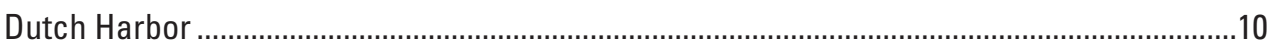

Daytona 100

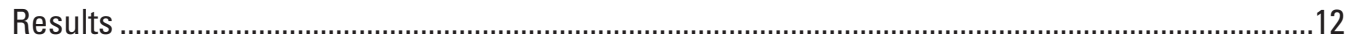

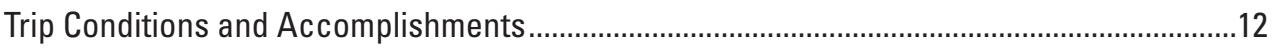

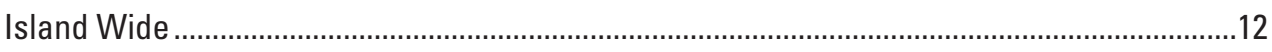

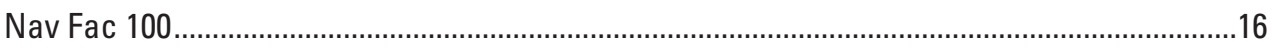

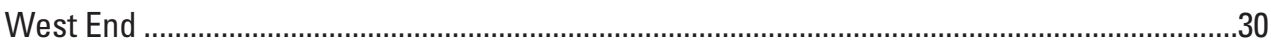

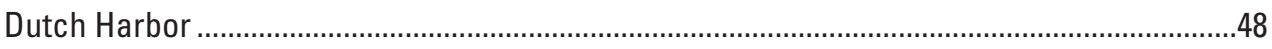

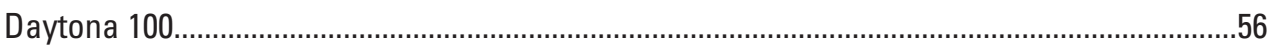

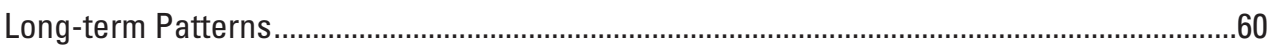

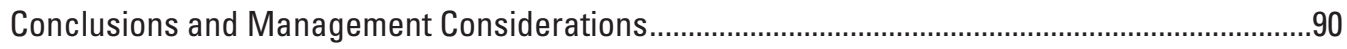

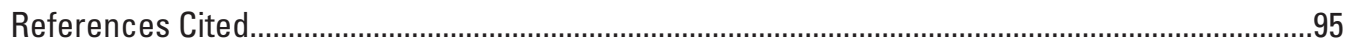

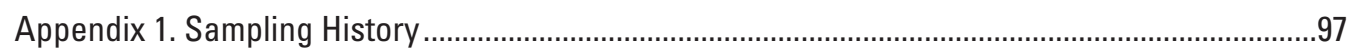

\section{Figures}

1. Map showing San Nicolas Island, California, study site locations and

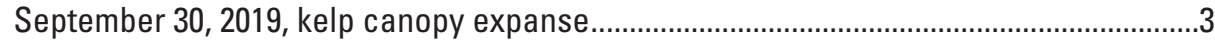

2. Diagram showing typical supersite layout .......................................................................

3. Photograph showing Laminaria spp. that appears to be L. farlowii .................................7

4. Photograph showing Laminaria spp. showing characteristics intermediate between $L$. farlowii and $L$. sechellii ........................................................................7

5. Photograph showing Nav Fac 100 site showing mix of understory kelps (Eisenia arborea, Pterygophora californica, and Laminaria spp.) and the brown alga, Dictyota binghamiae, October 2019..............................................................................

6. Photograph showing West End supersite showing boulder substrate with

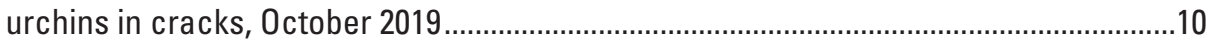

7. Photograph showing high reef topography at Dutch Harbor, October 2019....................11

8. Photographs showing Daytona 100 supersite, October 2019, showing urchin dominated and kelp dominated areas..

9. Graph showing an 18-year temperature record from subtidal readings at San Nicolas Island subtidal sites. 
10. Box plots of annual bottom temperature at Nav Fac and Dutch Harbor.

11. Graphs showing hourly bottom temperature data for Nav Fac 100 from November 22, 2015 to October 5, 2019, and the other three supersites from November 22, 2014 to October 5, 2019.

12. Bar graphs showing size distribution, by sex, of Semicossyphus pulcher fall 2014-fall 2019.

13. Bar graphs showing size distribution of Paralabrax clathratus, fall 2014-fall 2019........18

14. Graph showing mean densities of some swath-counted species that have demonstrated changing abundance at Nav Fac 100 from fall 2014 to fall 2019

15. Bar graphs showing Nav Fac 100 Macrocystis pyrifera stipe counts by season: Fall 2014-fall 2019

16. Bar graphs showing Nav Fac 100 Macrocystis pyrifera holdfast diameters by season: Fall 2014-fall 2019

17. Bar graphs showing size structure of Kelletia kelletii at Nav Fac 100 fall 2015fall 2019

18. Bar graphs showing Nav Fac 100 size structure of Megastraea undosa in fall 2014-fall 2019.

19. Bar graphs showing Nav Fac 100 size structure of Strongylocentrotus purpuratus in fall 2014-fall 2019

20. Bar graph showing Nav Fac 100 size structure of Strongylocentrotus franciscanus in fall 2014-fall 2019

21. Bar graphs showing mean percent cover categories by supersite, fall 2014 through fall 2019

22. Graph showing mean densities of some swath-counted species that have demonstrated changing abundance at West End from fall 2014 to fall 2019

23. Bar graphs showing West End Macrocystis pyrifera stipe counts by season: fall 2014-fall 2019.

24. Bar graphs showing West End Macrocystis pyrifera holdfast diameters by season: fall 2014-fall 2019

25. Bar graphs showing West End size structure of Megastraea undosa in fall 2017-fall 2019.

26. Bar graphs showing West End size structure of Strongylocentrotus purpuratus in fall 2014-fall 2019

27. Bar graphs showing West End size structure of Strongylocentrotus franciscanus in fall 2014-fall 2019

28. Graph showing mean densities of some swath-counted species that have demonstrated changing abundance at Dutch Harbor from fall 2014 to fall 2019

29. Bar graphs showing Dutch Harbor Macrocystis pyrifera counts by season: Fall 2014-spring 2019.

30. Bar graphs showing Dutch Harbor Macrocystis pyrifera holdfast diameters by season: fall 2014-fall 2019

31. Bar graphs showing Dutch Harbor size distribution of Megastraea undosa in spring 2017-fall 2019

32. Bar graph showing Dutch Harbor size structure of Strongylocentrotus purpuratus fall 2014-fall 2019

33. Bar graphs showing Dutch Harbor size structure of Strongylocentrotus franciscanus in fall 2014-fall 2019

34. Graph showing mean densities of some swath-counted species that have demonstrated changing abundance at Daytona 100 from fall 2014 to fall 2019 
35. Bar graph showing Daytona 100 Macrocystis pyrifera stipe counts by season: Fall 2014-fall 2019.

36. Bar graphs showing Daytona 100 Macrocystis pyrifera holdfast diameters by season: Fall 2014-fall 2019

37. Bar graphs showing size structure of Kelletia kelletii at Daytona 100 fall 2015fall 2019

38. Bar graphs showing Daytona 100 size structure of Megastraea undosa in fall 2014-fall 2019.

39. Bar graphs showing Daytona 100 size structure of Strongylocentrotus purpuratus in fall 2014-fall 2019

40. Bar graphs showing Daytona 100 size structure of Strongylocentrotus franciscanus (red urchins) in fall 2014-fall 2019

41. Graphs showing long-term trends in red and purple sea urchin abundance .................85

42. Graph showing Macrocystis pyrifera, understory kelp, and Cystoseira counts and fleshy red algae cover trends over time at Nav Fac

43. Graph showing Macrocystis pyrifera, understory kelp, and Cystoseira counts and fleshy red algae cover trends over time at Daytona.

44. Graph showing Macrocystis pyrifera, understory kelp, and Cystoseira counts and fleshy red algae cover trends over time at Dutch Harbor

45. Graph showing kelp and fleshy red algae cover trends over time at West End .............89

46. Graph showing Pisaster giganteus trends over time at West End, Dutch Harbor, and the original five swaths of Nav Fac and Daytona from fall 1980 to fall 2019

47. Graph showing Pycnopodia helianthoides trends over time at West End, Dutch Harbor, and the original five swaths of Nav Fac and Daytona from fall 1980 to fall 2019

48. Graph showing Patiria miniata trends over time at West End, Dutch Harbor, and the original five swaths of Nav Fac and Daytona from fall 1980 to fall 2019

49. Graph showing Megastaea undosa trends over time at West End, Dutch Harbor, and the original five swaths of Nav Fac and Daytona from fall 1980 to fall 2019

\section{Tables}

1. San Nicolas Island subtidal site waypoints and main transect bearings .........................4

2. Benthic swath locations relative to main transect line at each supersite .........................5

3. Species and measurements sampled on 10 -m by 2 -m swaths...........................................

4. Point contact and 1-square meter quadrat locations relative to main transect line at each supersite

5. Fish transect locations relative to main transect line at each supersite - start point and bearing

6. Summary of fall 2019 fish size estimates for all sites combined

7. Nav Fac 100 mean swath counts for fall 2014 through fall 2019 expressed as individuals per 20-square meter transect.

8. Sizes of invertebrates measured on swaths at Nav Fac 100, fall 2014 through fall 2019

9. Percent Strongylocentrotus purpuratus in three size bins at each supersite fall 2014-fall 2019

10. Percent Strongylocentrotus franciscanus in three size bins at each supersite fall 2014-fall 2019 
11. Nav Fac 100 mean of the species counted in twenty $1-m^{2}$ quadrats for fall 2014 through fall 2019

12. Nav Fac 100 point contact "species" ranked by the sum of points for fall 2014 through fall 2019.

13. Number of fish species counted, total count, and density on benthic and midwater transects and number of fish sized at each supersite in fall 2014 through fall 2019

14. Nav Fac 100 fish counts_Adult-in fall 2014 through spring 2019 by species...............38

15. West End mean swath counts for fall 2014 through fall 2019 expressed as individuals per 20 -square meter transect...

16. Sizes of invertebrates measured on swaths at West End, fall 2014 through fall 2019 ....44

17. West End mean of the species counted in twenty 1-m² quadrats for fall 2014 through fall 2019.

18. West End point contact "species" ranked by the sum of points for fall 2014 through fall 2019.

19. West End fish counts-Adult-in fall 2014 through fall 2019 by species

20. Dutch Harbor mean swath counts for fall 2014 through fall 2019 expressed as individuals per 20-square meter transect.

21. Sizes of invertebrates measured on swaths at Dutch Harbor, fall 2014 through fall 2019

22. Dutch Harbor mean of the species counted in twenty $1-\mathrm{m}^{2}$ quadrats for fall 2014 through fall 2019

23. Dutch Harbor point contact "species" ranked by the sum of points for fall 2014 through fall 2019.

24. Dutch Harbor fish counts-Adult —in fall 2014 through fall 2019 by species ..

25. Daytona 100 mean swath counts for fall 2014 through fall 2019 expressed as individuals per 20-square meter transect.

26. Sizes of invertebrates measured on swaths at Daytona 100, fall 2014 through fall 2019

27. Daytona 100 mean of the species counted in twenty $1-m^{2}$ quadrats for fall 2014 through fall 2019

28. Daytona 100 point contact "species" ranked by the sum of points for fall 2014 through fall 2019 .

29. Daytona 100 fish counts-Adult-in fall 2014 through fall 2019 by species .84 


\section{Conversion Factors}

International System of Units to U.S. customary units

\begin{tabular}{|c|c|c|}
\hline Multiply & By & To obtain \\
\hline \multicolumn{3}{|c|}{ Length } \\
\hline centimeter $(\mathrm{cm})$ & 0.3937 & inch (in.) \\
\hline millimeter (mm) & 0.03937 & inch (in.) \\
\hline meter (m) & 3.281 & foot $(\mathrm{ft})$ \\
\hline meter (m) & 1.094 & yard (yd) \\
\hline \multicolumn{3}{|c|}{ Area } \\
\hline square meter $\left(\mathrm{m}^{2}\right)$ & 0.0002471 & acre \\
\hline
\end{tabular}

Temperature in degrees Celsius $\left({ }^{\circ} \mathrm{C}\right)$ may be converted to degrees Fahrenheit $\left({ }^{\circ} \mathrm{F}\right)$ as follows: ${ }^{\circ} \mathrm{F}$ $=\left(1.8 \times{ }^{\circ} \mathrm{C}\right)+32$.

\section{Datum}

Horizontal coordinate information is referenced to the World Geodetic System of 1984 (WGS 84).

\section{Abbreviations}

$\begin{array}{ll}\text { RPC } & \text { random point contact } \\ \text { SNI } & \text { San Nicolas Island } \\ \text { SSWS } & \text { sea star wasting syndrome } \\ \text { USFWS } & \text { U.S. Fish and Wildlife Service } \\ \text { USGS } & \text { U.S. Geological Survey } \\ \text { WS } & \text { withering syndrome }\end{array}$





\title{
Kelp Forest Monitoring at Naval Base Ventura County, San Nicolas Island, California: Fall 2019, Sixth Annual Report
}

\author{
By Michael C. Kenner and Joseph Tomoleoni
}

\section{Abstract}

The U.S. Geological Survey conducts ecological monitoring of rocky subtidal communities at four permanent sites around San Nicolas Island. The sites-Nav Fac 100, West End, Dutch Harbor, and Daytona 100 — were based on ones that had been monitored since 1980 by the U.S. Geological Survey and, in cooperation with the U.S. Navy, were combined or expanded in 2014 for better comparability with monitoring programs conducted at the other California Channel Islands. At the sites, we counted a suite of kelps and invertebrates on benthic band transects, measured bottom cover of algae and sessile invertebrate species in quadrats, and counted and sized fish on swimming transects. Holdfast diameter and number of stipes of giant kelp (Macrocystis pyrifera) were recorded on these transects and size data were collected for urchins, sea stars, and shelled mollusks. Bottom temperatures were recorded at hourly intervals by archival data loggers that were deployed at the sites. Typically, this monitoring work is conducted semi-annually, in fall and spring. Because the spring 2020 trip was cancelled due to the Coronavirus Disease 2019 pandemic, this report focuses primarily on data collected in fall 2019 and makes comparisons with data collected in previous years, beginning in fall 2014.

The sites are distributed around the island and differ in their physical and ecological characteristics. Nav Fac 100, situated on the north side of San Nicolas Island, has a relatively low benthic profile. The invasive brown alga Sargassum horneri was first observed at this site in 2015. West End, to the southwest of the island, also lacks much bottom relief but has more crevice habitat associated with boulders. For almost three decades, West End has been a focal point for the small, but growing, population of southern sea otters (Enhydra lutris nereis) at the island. Dutch Harbor, on the south side, has many high relief rocky reefs and had the greatest fish and non-motile invertebrate densities. Daytona 100 , on the southeast side, has moderate relief and has remained a patchwork of kelp and sea urchin dominated areas.

There were no major changes at the sites since spring 2019, but some trends observed during the last few years continued whereas others changed. Red urchins continued a declining trend (observed during the last 4 years) at Daytona
100. The wavy turban snail (Megastraea undosa) began to increase rapidly at Nav Fav 100 in 2015 and has subsequently been increasing at the other sites as well, after more than a decade of very low numbers at all sites. Sea star wasting syndrome, which has devastated multiple species of sea stars along the Pacific coast of North America, affected most species at San Nicolas Island in the year prior to the fall 2014 sampling. Since then, there has been a reduction in the number of bat stars (Patiria miniata), and very few sea stars of other species have been observed. There has been a slight recovery of $P$. miniata since 2016 but little sign of change in other species. All the sites had a slight decline in the densities of purple urchins following an increase during the previous 2 years. Long-term data are presented to illustrate trends and changes during almost four decades of monitoring this dynamic system.

\section{Introduction}

San Nicolas Island (SNI), outermost of the California Channel Islands, is home to a diverse group of terrestrial and marine organisms and includes kelp forests and rocky reef habitats. Because the kelp forests surrounding SNI fall within the management boundary of the SNI Integrated Natural Resources Management Plan (U.S. Navy, 2015), and as part of the sea otter military readiness plan, surveys of this ecologically important ecosystem are necessary to provide Navy natural resource managers with knowledge of trends in the population abundance of particular species. In addition, long-term surveys allow for an understanding of potential changes in species diversity and community composition as a result of trophic or other interactions.

The kelp forest ecosystem is defined by the presence of brown algae of the order Laminariales. These species typically grow on relatively shallow (less than 30 meters $[\mathrm{m}])$, rocky reefs in temperate seas. Kelp forests are among the most productive marine ecosystems (Duggins and others, 1989) and provide the primary habitat for several species of fishes, invertebrates, and algal assemblages (Steneck and others, 2002). In addition, kelp forests have been shown to be important carbon dioxide sinks (Wilmers and others, 2012). These highly dynamic ecosystems are extremely variable, and 
both top-down and bottom-up ecological controls drive this rich trophic environment. In addition to "normal" variability, kelp forests can undergo extreme regime shifts from kelp canopy forested areas to barrens characterized by high densities of urchins and encrusting coralline algae associated with the absence of canopy and understory kelps (Harrold and Reed, 1985; Harrold and Pearse, 1987).

Macrocystis pyrifera, commonly known as giant kelp, can increase faunal diversity on rocky reefs largely as a direct result of its dominant three-dimensional structure (Miller and others, 2018). Giant kelp also can grow at rates of $15-50$ centimeters $(\mathrm{cm})$ per day and, over a lifespan of a few years, shed vast amounts of carbon in the form of drift. This profusion of detritus can support herbivores and detritivores in the community or be exported to beaches and the ocean depths (Schiel and Foster, 2015). Macrocystis pyrifera forests and the species that inhabit these ecosystems are influenced by several environmental conditions, such as wave exposure, water temperature, water clarity, bottom depth and composition, species composition, and the density of kelp and other algal assemblages (Dayton, 1985; Schiel and Foster, 2015).

The kelps of SNI include the surface canopy forming species, $M$. pyrifera, the stipitate understory canopy forming kelps, Pterygophora californica and Eisenia arborea, and prostrate Laminaria spp. The SNI kelp forests not only provide food and shelter for fishes and invertebrates within the habitat, but they also support higher trophic level consumers, such as marine birds and several marine mammal species including the southern sea otter (Enhydra lutris nereis), a keystone species and a major predator on sea urchins and other marine invertebrates.

Concern regarding the vulnerability of the southern sea otter population led the U.S. Fish and Wildlife Service (USFWS) to translocate 140 southern sea otters from the central California coast to SNI between 1987 and 1990. Due to unexpected mortalities, a high rate of emigration, and unknown factors, only approximately 14 translocated otters are thought to have remained at SNI by 1991 (U.S. Fish and Wildlife Service, 2012). After a few years, however, the sea otter population at the island began to increase and, in 2019, more than 150 individuals were counted there (Yee and others, 2020). Sea otters evolved as an ecologically important predator in the North Pacific kelp forest ecosystem, but their repopulation of regions from which they were extirpated in the 19th century has important economic (Carswell and others, 2015) and community ecology implications (Estes and Duggins, 1995). Since their reintroduction, sea otters at SNI have been concentrated mostly around the west end of the island, with expanding seasonal use of the south and north side in recent years (Yee and others, 2020). An ecosystem shift from urchin dominated to kelp dominated, that occurred at a site at the west end of the island in the early 2000 s, though initiated by sea urchin disease, was likely facilitated (to some degree) by sea otter foraging (Kenner and Tinker, 2018).
San Nicolas Island's kelp forest ecosystems are the target of many fisheries, including urchin and lobster. Both fisheries could result in a loss of population control over an important grazer in the system. Urchin fisheries, which target the larger red sea urchin, Strongylocentrotus franciscanus [Mesocentrotus franciscanus], may release the smaller but more mobile purple sea urchin, S. purpuratus, from competitive control (Dayton and others, 1998), whereas lobster fisheries may release purple sea urchins from predatory control (Lafferty, 2004). Owing to the distance from the mainland, however, SNI kelp forests and reefs have been somewhat protected from the degree of harvest and other anthropogenic impacts experienced by the southern California mainland and islands closer to the coast. Regardless, SNI has experienced several purple urchin over-grazing events in the previous few decades.

Invasive species are another issue. Although the brown alga Sargassum muticum has been established at the island for decades, $S$. horneri has only recently been seen at SNI. Sargassum horneri has a demonstrated capability to outcompete native kelps at some of the other Channel Islands but it is unclear what indirect effects it may have on community structure (Marks and others, 2015; Sullaway and Edwards, 2020).

The U.S. Geological Survey (USGS) implemented a kelp forest monitoring program for the U.S. Navy at SNI in 2014, building on sites and methods established and monitored by the USFWS and USGS scientists since 1980 (appendix 1). This report focuses on data collected during a sampling expedition to these sites in fall 2019 (October 1-5). Normally, this report would include results from a spring 2020 survey, but that trip as well as the fall 2020 trip were cancelled due to the Coronavirus Disease 2019 (COVID-19) pandemic. The data are compared with data collected during 10 trips from fall 2014 through spring 2019. Differences in counts between this and previous expeditions can result from seasonal factors, stochastic variation, or sampling error, but temporal comparison can reveal population trends. Where appropriate, long-term data collected during the 33 years before the implementation of these slightly revised protocols will be presented in order to lend some context to the observations reported here.

Genus and species names used in this report are those currently recognized as valid in the Integrated Taxonomic Information System (ITIS.gov). Upon first use, the name recognized as valid by the World Register of Marine Species (WoRMS; marinespecies.org) is shown in brackets if different. The exception is Sargassum horneri which does not show up in any discernable form in ITIS.gov. 


\section{Methods}

\section{Site Design and Sampling Protocols}

Four permanent "supersites" were sampled at the island and each is composed of two subunit sites (figs. 1,2). Most of these sites were set up as part of the USGS SNI Subtidal Baseline project described in appendix 1. Associated with each of these eight subunit sites is a 50-meter $(\mathrm{m})$ main transect perpendicular to five $10-\mathrm{m}$ by $2-\mathrm{m}$ benthic band transects (swaths) and ten 1-square meter $\left(\mathrm{m}^{2}\right)$ random point contact (RPC) quadrats (see details in the following subsections). The 50-m main transects of the two subunit sites are connected in a linear fashion with the 50-m end of one connecting to the $0-\mathrm{m}$ end of the other, resulting in a continuous $100-\mathrm{m}$ main transect. The exception to this is Dutch Harbor, where the subunit sites are on adjacent reefs. As explained in appendix 1, the supersites at West End and Dutch Harbor each have ten 50-m-long fish transects, whereas Nav Fac 100 and Daytona 100 each have five 50-m fish transects (fig. 2).
At each supersite, a TidbiT ${ }^{\circledR}$ v2 model UTBI-001 (Onset Computer Corporation, Bourne, Massachusetts) archival temperature logger was deployed. These were set to record at 1-hour intervals and were installed on the sea floor (10-12 m deep) at the midpoint of the $100-\mathrm{m}$ main transects at Nav Fac 100, West End, and Daytona 100 and at $0 \mathrm{~m}$ at East Dutch Harbor. See figure 2 for a schematic of the sampling layout at Nav Fac 100 supersite as an example and table 1 for site locations.

\section{Swaths/Band Transects}

The swath/band transect method was used to determine densities of kelps and benthic macroinvertebrates as well as to gather size data on some of these populations. Ten permanent $10-\mathrm{m}$ by $2-\mathrm{m}$ swaths, which run perpendicular to the main $100-\mathrm{m}$ transect, were sampled by divers at each supersite. See table 2 for swath locations and orientations. Although nominally $20 \mathrm{~m}^{2}$, the actual substrate sampled per swath is more because of reefs, undercuts, boulders, and other benthic features. First, researchers attached a meter tape at a fixed point on the main transect and swam it out to

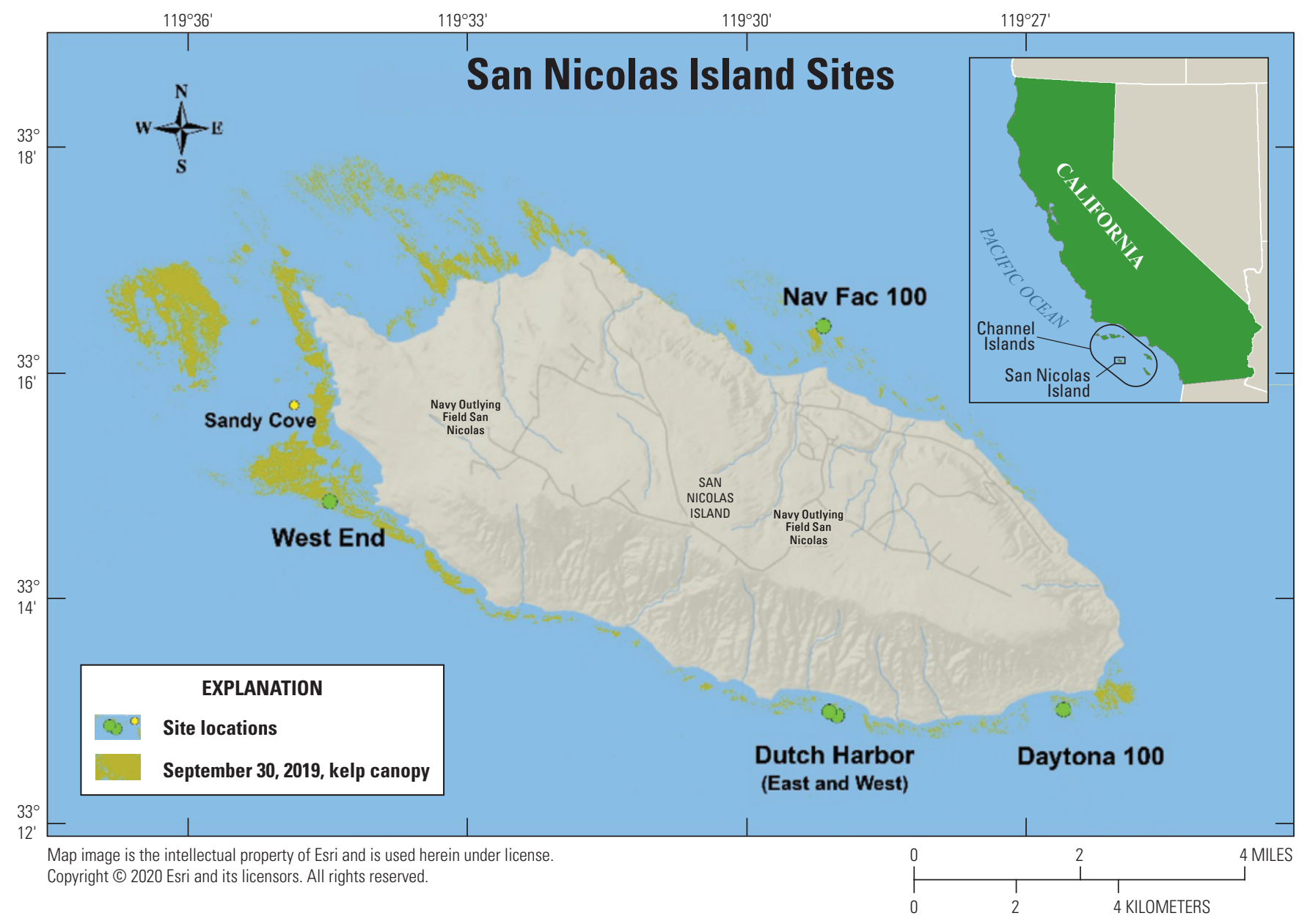

Figure 1. San Nicolas Island, California, study site locations and September 30, 2019, kelp canopy expanse. 


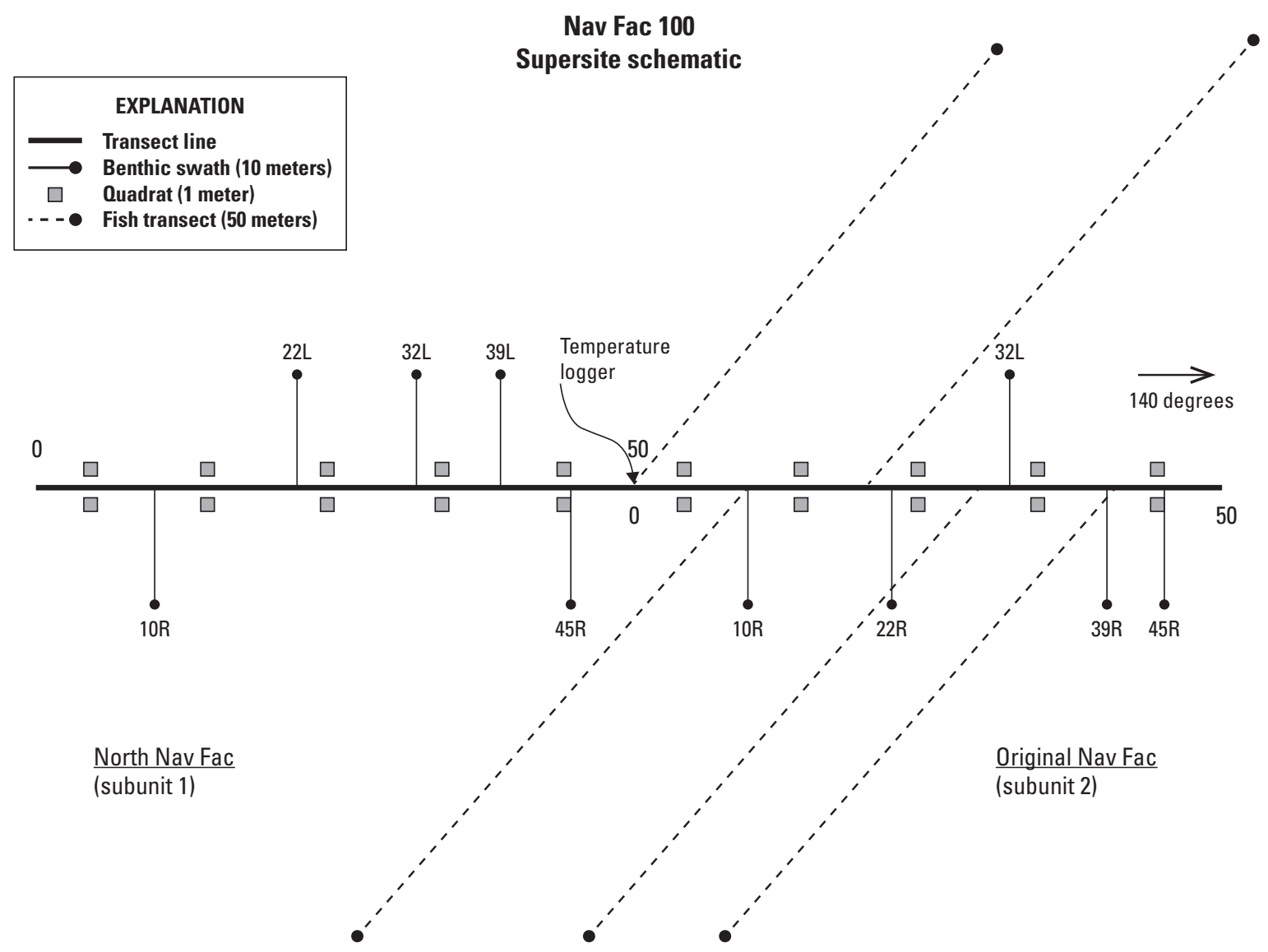

Figure 2. Typical supersite layout (Nav Fac 100). Note that fish transects are on cardinal compass bearings and may not run perpendicular to the main transect line.

Table 1. San Nicolas Island subtidal site waypoints (World Geodetic System of 1984, WGS 84) and main transect bearings.

[TidbiT ${ }^{\circledR}$ logger location denoted by *. Abbreviations: m, meter; N, north; - , no data available; ${ }^{\circ}$, degrees; W, west; S, south]

\begin{tabular}{|c|c|c|c|}
\hline Marker name & Latitude & Longitude & Transect bearing \\
\hline \multicolumn{4}{|c|}{ Nav Fac 100} \\
\hline North Nav Fac $0 \mathrm{~m}$ & $\mathrm{~N} 33.27385^{\circ}$ & W119.48681 & $140^{\circ}$ \\
\hline Nav Fac $0 \mathrm{~m} / \mathrm{N}$ Nav Fac $50 \mathrm{~m} *$ & $\mathrm{~N} 33.27354^{\circ}$ & W119.48647 & $140^{\circ}$ \\
\hline Nav Fac $50 \mathrm{~m}$ & $\mathrm{~N} 33.27310^{\circ}$ & W119.48626 & - \\
\hline \multicolumn{4}{|c|}{ West End } \\
\hline West End Urchin $0 \mathrm{~m}$ & $\mathrm{~N} 33.24772^{\circ}$ & W119.57419 & $100^{\circ}$ \\
\hline W End Kelp $0 \mathrm{~m} / \mathrm{W}$ End Urchin $50 \mathrm{~m} *$ & $\mathrm{~N} 33.24762^{\circ}$ & W119.57367º & $110^{\circ}$ \\
\hline West End Kelp $50 \mathrm{~m}$ & $\mathrm{~N} 33.24742^{\circ}$ & W119.57318 & - \\
\hline \multicolumn{4}{|c|}{ Dutch Harbor } \\
\hline West Dutch Harbor $0 \mathrm{~m}$ & $\mathrm{~N} 33.21652^{\circ}$ & W119.48547 & $55^{\circ}$ \\
\hline West Dutch Harbor $50 \mathrm{~m}$ & $\mathrm{~N} 33.21672^{\circ}$ & W119.48503은 & - \\
\hline East Dutch Harbor 0 m* & $\mathrm{N} 33.21598^{\circ}$ & W119.48407 & $25^{\circ}$ \\
\hline East Dutch Harbor $50 \mathrm{~m}$ & $\mathrm{~N} 33.21630^{\circ}$ & W119.48381 ${ }^{\circ}$ & - \\
\hline \multicolumn{4}{|c|}{ Daytona 100} \\
\hline South Daytona $0 \mathrm{~m}$ & $\mathrm{~N} 33.21643^{\circ}$ & W119.44420 & $0^{\circ}$ \\
\hline Daytona $0 \mathrm{~m} / \mathrm{S}$ Daytona $50 \mathrm{~m} *$ & $\mathrm{~N} 33.21687^{\circ}$ & W119.44412º & $0^{\circ}$ \\
\hline Daytona $50 \mathrm{~m}$ & $\mathrm{~N} 33.21731^{\circ}$ & $\mathrm{W} 119.44400^{\circ}$ & - \\
\hline
\end{tabular}


Table 2. Benthic swath locations relative to main transect line at each supersite.

[R or L indicates the swath is to the right or left of main transect when facing from 0 meter $(\mathrm{m})$ to 50 meters. Note that the $45 \mathrm{R}$ swath at Daytona was lost owing to sand burial in 1983, so the 22L swath was set up 2 years later as a replacement]

\begin{tabular}{|c|c|c|c|c|c|}
\hline Supersite and sites & \multicolumn{5}{|c|}{ Swaths } \\
\hline \multicolumn{6}{|c|}{ Nav Fac 100} \\
\hline Nav Fac & $10 \mathrm{R}$ & $22 \mathrm{R}$ & $32 \mathrm{~L}$ & $39 \mathrm{R}$ & $45 \mathrm{R}$ \\
\hline North Nav Fac & $10 \mathrm{R}$ & $22 \mathrm{~L}$ & $32 \mathrm{~L}$ & 39L & $45 \mathrm{R}$ \\
\hline \multicolumn{6}{|c|}{ West End } \\
\hline West End Urchin & $10 \mathrm{~L}$ & $22 \mathrm{~L}$ & $32 \mathrm{R}$ & $39 \mathrm{~L}$ & $45 \mathrm{~L}$ \\
\hline West End Kelp & $10 \mathrm{R}$ & $22 \mathrm{R}$ & $32 \mathrm{~L}$ & $39 \mathrm{R}$ & $45 \mathrm{~L}$ \\
\hline \multicolumn{6}{|c|}{ Dutch Harbor } \\
\hline West Dutch & $10 \mathrm{R}$ & $22 \mathrm{~L}$ & $32 \mathrm{~L}$ & $39 \mathrm{~L}$ & $45 \mathrm{~L}$ \\
\hline East Dutch & $10 \mathrm{R}$ & $22 \mathrm{R}$ & $32 \mathrm{~L}$ & $39 \mathrm{R}$ & $45 \mathrm{R}$ \\
\hline \multicolumn{6}{|c|}{ Daytona 100} \\
\hline Daytona & $10 \mathrm{R}$ & $22 \mathrm{R}$ & $22 \mathrm{~L}$ & $32 \mathrm{~L}$ & $39 \mathrm{~L}$ \\
\hline South Daytona & $10 \mathrm{R}$ & $22 \mathrm{~L}$ & $32 \mathrm{R}$ & $39 R$ & $45 \mathrm{R}$ \\
\hline
\end{tabular}

an eyebolt embedded in the sea floor approximately $10 \mathrm{~m}$ away. On each swath, the divers, using meter sticks as guides, then counted the target organisms (table 3 ) that occurred within $1 \mathrm{~m}$ on either side of the tape. Divers measured in situ sea star and mollusk size (millimeters [mm]) - maximum arm length from center for sea stars (following the curve of the arm) and maximum shell length for mollusks. For giant kelp (M. pyrifera) greater than $1 \mathrm{~m}$ tall (herein referred to as adults), the divers measured the holdfast diameter at the base $(\mathrm{cm})$ and counted stipes at $1 \mathrm{~m}$ above the substrate. Holdfast diameters give an indication of the $M$. pyrifera age structure because the holdfast continues to grow throughout the life of the alga. Stipe counts are more variable with age but give an indication of algal biomass. Kelps of the genus Laminaria occur at SNI in a few different forms. Most of these kelps appear to be L. farlowii (fig. 3) or have a range of forms blending traits of $L$. farlowii (very short stipes and a single entire bullate blade) and $L$. setchellii (a single smooth but divided blade with a tall stiff stipe; fig. 4) but very few of them have the typical form of $L$. setchellii (Abbott and Hollenberg, 1976). Because of the taxonomic ambiguity described here, these kelps are tallied and presented as "Laminaria spp." Note that in the referenced text, $L$. setchellii is erroneously referred to as $L$. dentigera.

We measured the test diameter $(\mathrm{mm})$ of a subsample of sea urchins (Strongylocentrotus spp.) - about 200 per species per supersite. Divers did not measure urchins on swaths but instead measured them in situ near the main transect. The urchins were measured as they were encountered to avoid size selective bias.

\section{Random Point Contact Sampling}

Random point contact (RPC) sampling was used to estimate cover of exposed substrate as well as cover of algae and (primarily) non-motile invertebrates. Benthic percent cover data were collected in $1-\mathrm{m}^{2}$ permanent quadrats placed $1 \mathrm{~m}$ to the left or right of the main transect at 20 fixed locations at each supersite. Within each quadrat, 20 points were distributed in a fixed pattern, each representing an estimate of 5-percent cover. Divers identified all organisms that intersected with an imaginary line running vertically through each point up to 1 meter above the substratum. Each species was scored only once per point, even if multiple individuals of the same species intersected that point. Because of this method of scoring multiple layers, total cover of all species often exceeded 100 percent, but the cover of any individual species could not be greater than 100 percent (20 points). The list of taxa recorded was open and ranged from individual species to species groups, for example, "orange encrusting sponge." Substrate type (bare rock or sand) was scored if exposed. Motile invertebrate species were moved, if possible, to access affixed species or substrate beneath them but were scored if they were ophiuroids (brittle stars), small holothurians (sea cucumbers), or if not moved. See table 4 for quadrat locations and orientations.

\section{1-Meter Quadrats}

The 1- $\mathrm{m}^{2}$ quadrats, which define the location of the RPC sampling, also were used to sample densities of certain smaller species that are rare or difficult to count on swaths. Unlike the RPC sampling, which yields a measure of cover, these were actual counts of individuals. Within each quadrat, divers counted Norrisia norrisii (Norris's top snail), any Tegula species observed, Lithopoma gibberosa [Pomaulax gibberosus] (red turban snail), Cypraea spadicea [Neobernaya spadicea] (chestnut cowrie), Styela montereyensis (stalked tunicate), Kelletia kelletii (Kellet's whelk), Tealia lofotensis [Urticina equis] (white-spotted rose anemone), Tethya aurantia [Tethya californiana] (orange puffball sponge), and Sargassum horneri (an invasive brown alga). These last four species also were counted on swaths.

\section{Visual Fish Transects}

The purpose of the fish transects was to estimate fish density, size, sex (if obviously sexually dimorphic), and vertical distribution in the water column. The fish transects were $50 \mathrm{~m}$ long with a fixed beginning point along the main site transect and a permanently chosen compass heading. Except for those that follow the main transect line, these headings are north, south, east, or west and may be as much as 40 degrees $\left(^{\circ}\right)$ off perpendicular to the main transect line (fig. 2). The midwater and bottom portions of each transect were sampled separately. Midwater transects were $5 \mathrm{~m}$ 
Table 3. Species and measurements sampled on 10-m by 2-m swaths.

[mm, millimeter; <, less than; m, meter; >, greater than; $\mathrm{cm}$, centimeter]

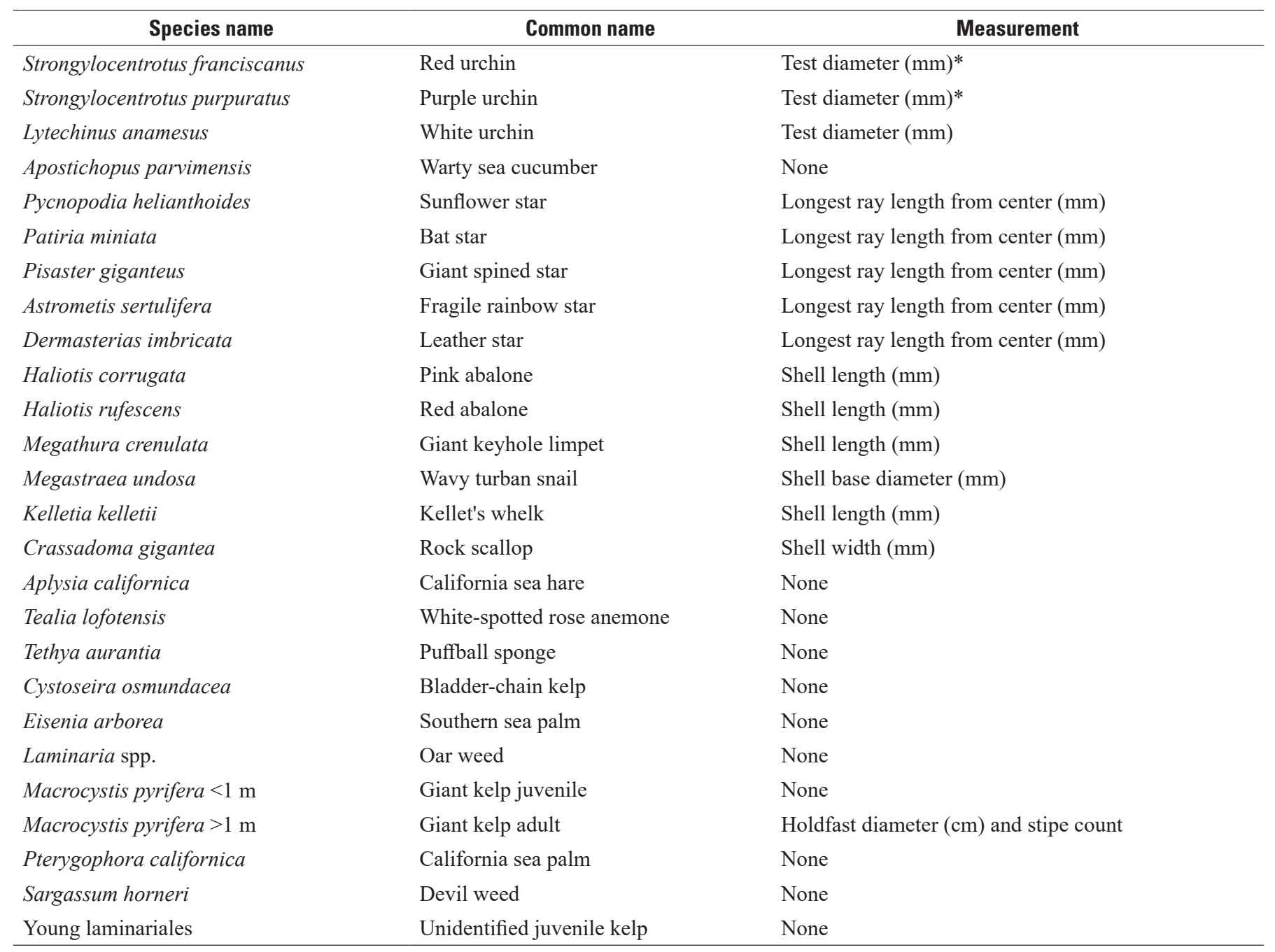

*Measured outside of swaths.

wide and encompassed the entire water column, except the bottom $2 \mathrm{~m}$. Bottom transects were $2 \mathrm{~m}$ wide and included only the bottom $2 \mathrm{~m}$ of the water column. Divers attached a meter tape at the specified location on the main transect line and swam the prescribed compass heading, identifying, counting, and estimating size of all conspicuous fishes on each transect. If sex was visually distinguishable, like in the case of Semicossyphus pulcher (California sheephead) or Hexagrammos decagrammus (kelp greenling), it was recorded as well. Juveniles also were recorded separately when morphologically distinct. Divers estimated total length (TL) of small fish (less than 20-cm TL) to the nearest $1 \mathrm{~cm}$ and larger fish (greater than $20 \mathrm{~cm}$ ) to the nearest $5-\mathrm{cm}$ interval. For schools of a species, size ranges were recorded. As described previously, Nav Fac 100 and Daytona 100 each have 5 fish transects, but West End and Dutch Harbor each have 10. At Dutch Harbor, owing to high counts typically recorded there, fish were only sized on two midwater and two bottom transects at the West Dutch Harbor site and two of each at the East Dutch Harbor site. Counts without size estimations were done on the remaining transects there. See table 5 for fish transect locations and headings. 


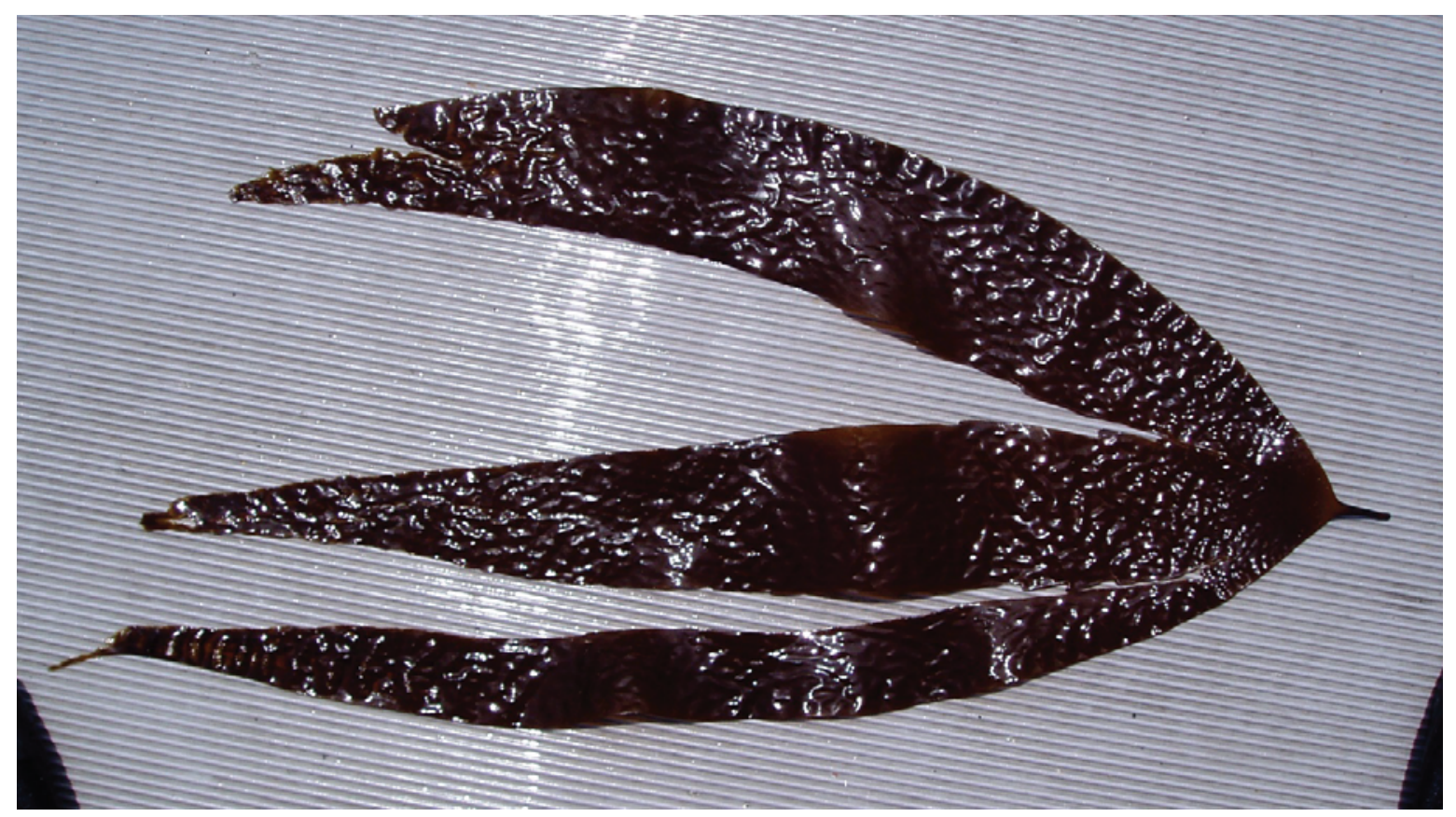

Figure 3. Laminaria spp. that appears to be L. farlowii. This form typically is found at the Nav Fac 100 and West End supersites, often without blade divisions. Plant is approximately 50 centimeters long. Photograph by Michael Kenner, April 2006.

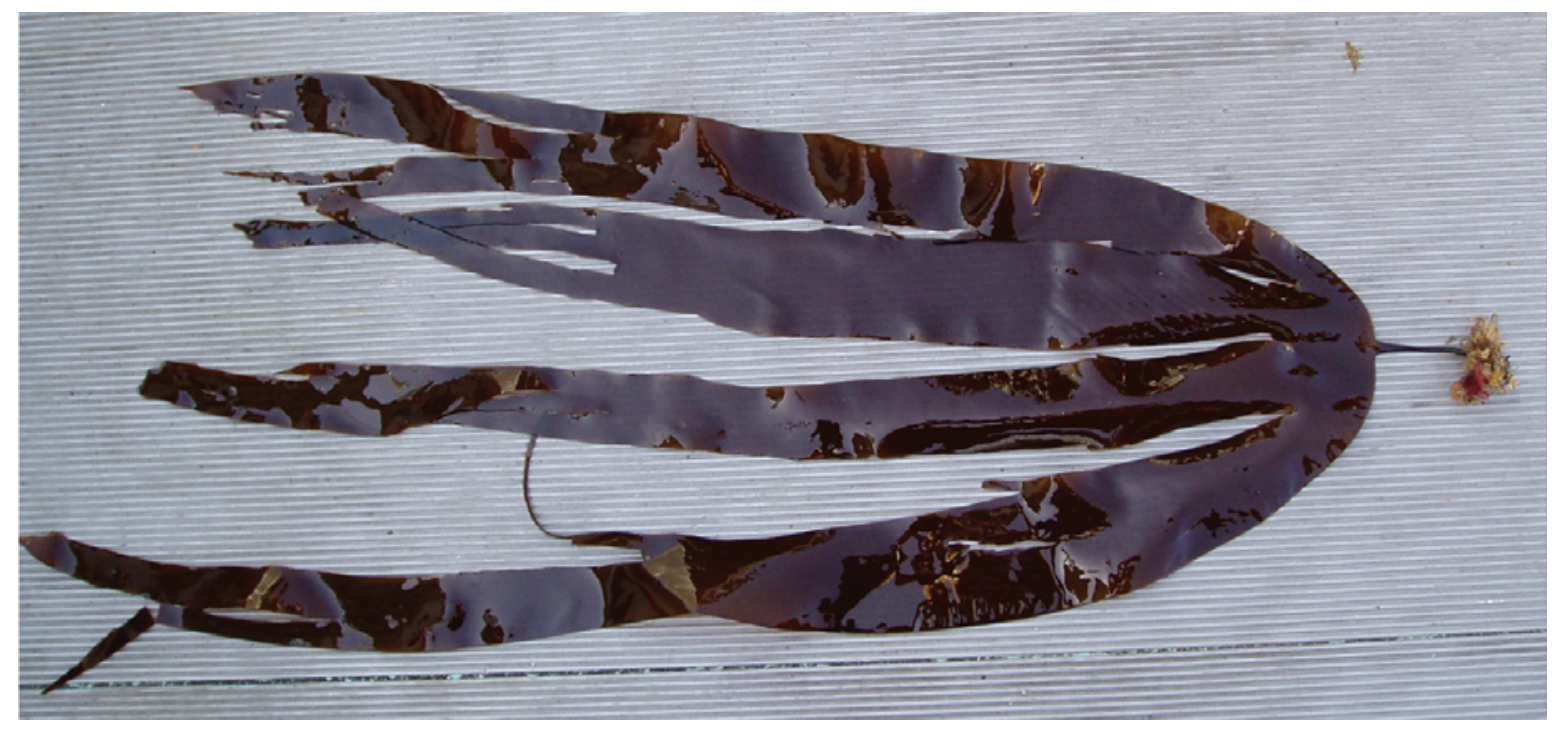

Figure 4. Laminaria spp. showing characteristics intermediate between L. farlowii and L. sechellii (short stipe, prostrate attitude, smooth blade). This form typically is found at the Dutch Harbor and Daytona 100 supersites, often without blade divisions. Plant is approximately 80 centimeters long. Photograph by Michael Kenner, April 2006. 
Table 4. Point contact and 1-square meter $\left(\mathrm{m}^{2}\right)$ quadrat locations relative to main transect line at each supersite.

[R or $\mathrm{L}$ indicates the swath is to the right or left of main transect when facing from 0 meter $(\mathrm{m})$ to $50 \mathrm{~m}$ ]

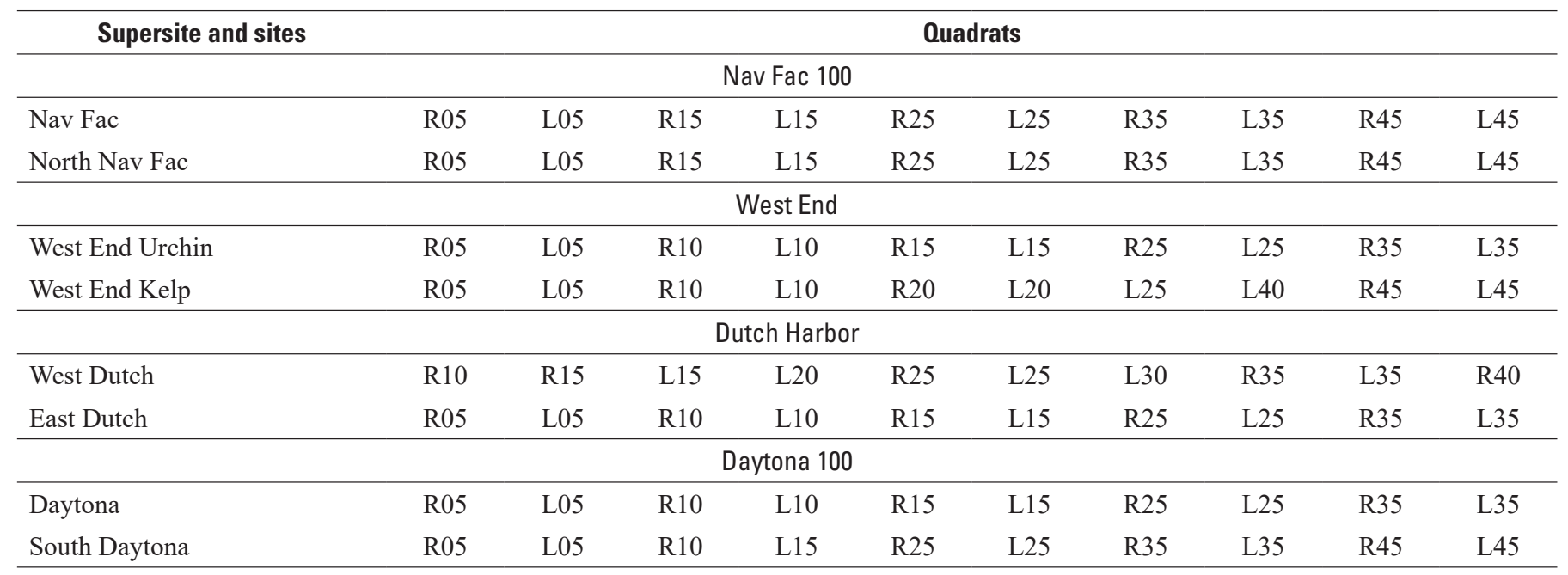

Table 5. Fish transect locations relative to main transect line at each supersite—start point and bearing.

[* Fish not sized on these transects; ON means transect is on the main line. Abbreviations: m, meter; E, east; W, west; N, north; S, south]

\begin{tabular}{|c|c|c|c|c|c|}
\hline \multirow{2}{*}{ Supersite and sites } & \multicolumn{5}{|c|}{ Transects } \\
\hline & 1 & 2 & 3 & 4 & 5 \\
\hline \multicolumn{6}{|c|}{ Nav Fac 100} \\
\hline \multicolumn{6}{|c|}{ West End } \\
\hline West End Urchin & $0-\mathrm{m} \mathrm{N}$ & $10-\mathrm{m} \mathrm{N}$ & $20-\mathrm{m} \mathrm{N}$ & $30-\mathrm{m} \mathrm{N}$ & $\mathrm{ON}$ \\
\hline \multicolumn{6}{|c|}{ Dutch Harbor } \\
\hline West Dutch & $0-\mathrm{m} \mathrm{W}$ & 10-m W & $30-\mathrm{m} \mathrm{W}^{*}$ & $45-\mathrm{m} \mathrm{W}^{*}$ & $\mathrm{ON}^{*}$ \\
\hline East Dutch & $0-\mathrm{m} \mathrm{E}$ & 10-m W & $20-\mathrm{m} \mathrm{E}^{*}$ & $30-\mathrm{m} \mathrm{W}^{*}$ & 40-m E* \\
\hline \multicolumn{6}{|c|}{ Daytona 100} \\
\hline Daytona & $0-\mathrm{m} \mathrm{E}$ & $0-\mathrm{m} \mathrm{W}$ & 10-m E & $20-\mathrm{m} \mathrm{W}$ & 30-m E \\
\hline
\end{tabular}




\section{Supersite Descriptions}

See table 1 for subunit site coordinates and transect orientations and figure 1 for supersite locations.

\section{Nav Fac 100}

The Nav Fac 100 supersite is situated on the north side of the island. It is exposed to the prevailing northwest swell and wind and has a generally flat bottom with a few 1-2-m high ledges and undercuts. The TidbiT ${ }^{\circledR}$ logger was deployed at approximately $12 \mathrm{~m}$ in depth. From the time that the original Nav Fac site (the southern $50 \mathrm{~m}$ of the supersite) was established in fall 1980 until 1989, it was kelp dominated with the bottom largely covered by encrusting and erect coralline algae, the fucoid alga, Cystoseira osmundacea [Stephanocystis osmundacea], and the tube building snail, Serpulorbis squamiger [Thylocodes sqamigerus]. Kelps were common, including understory kelps Laminaria spp. and $P$. californica and canopy-forming giant kelp, M. pyrifera. By the spring of 1990, a strong recruitment of the purple sea urchin, S. purpuratus, had transformed most of the site to an urchin barren. Though urchin densities fluctuated over time, the west side of the site did not recover to a kelp dominated state. That part of the site is very flat, and the bottom is composed of soft sandstone, which may impede kelp recovery because there is no barrier to urchin movement and storms easily remove kelp holdfasts. The east side of the site has slightly higher relief and C. osmundacea, P. californica, and Laminaria spp. are common there. Fish densities and species diversity generally have been low throughout the site. Three fish transects run west from the main line, over a flat uniform benthos that was mostly devoid of refuge and kelp, whereas the remaining two fish transects run east of the main line, over an area with more habitat heterogeneity, including rocky ridges, boulders, and ledges. Greater fish abundance and diversity have routinely been observed on the more rugose eastern portion of the site compared to the three transects that traverse flat bottom to the west. The North Nav Fac subunit, which was established in fall 2014, included some kelp dominated and urchin dominated areas and had swaths and quadrats in both states. Urchin densities fell after the spring 2015 sampling trip and have remained low since then. Kelp recovery, however, has been slow but patches of understory kelps have become established and C. osmundacea and various annual brown algae cover large areas (fig. 5). The invasive brown alga S. horneri, which had not been observed at SNI before, first appeared at the site in fall 2015.

\section{West End}

The West End supersite is located off the southwest shore of the island. The bottom generally is flat with scattered boulders to 1 meter in size, low step-like ridges, and sand patches. The TidbiT ${ }^{\circledR}$ logger was deployed at a depth of about $11 \mathrm{~m}$. The supersite is very exposed to prevailing northwest swell and wind. Originally designed with one 50-m transect installed in an urchin dominated area and one in a

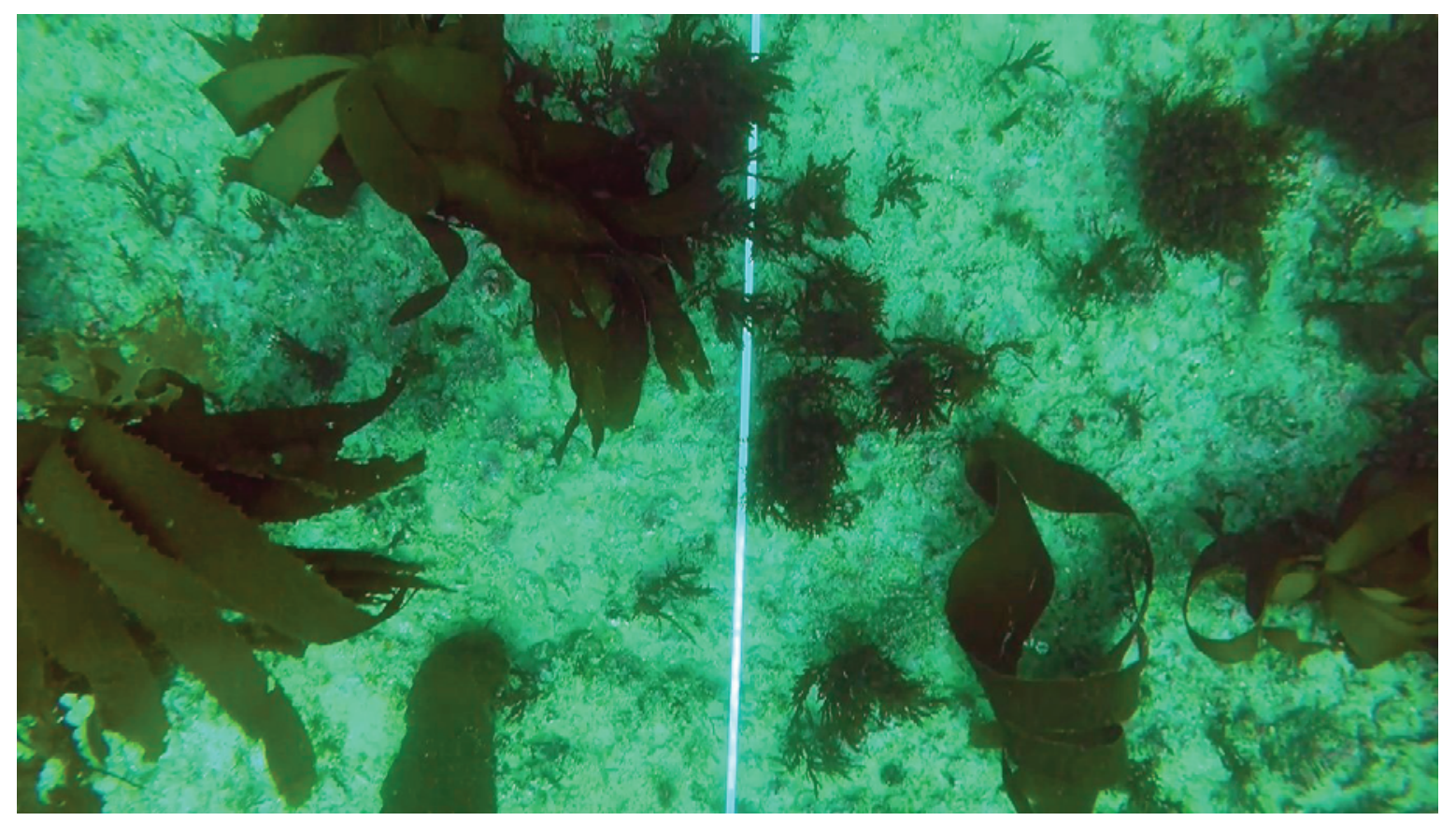

Figure 5. Nav Fac 100 site showing mix of understory kelps (Eisenia arborea, Pterygophora californica, and Laminaria spp.) and the brown alga, Dictyota binghamiae, October 2019 (captured from video by Shannon Myers, University of California, Santa Cruz). 
kelp dominated area, this dynamic region underwent several shifts between kelp and urchin states since sampling began in 1980. In 2001, there was a dramatic shift at the supersite from an entirely urchin dominated state to one in which they were almost entirely absent. The cause of this shift was likely an undocumented sea urchin disease. Foraging by sea otters that frequent the area may have helped maintain the macroalgae dominated system that subsequently developed there.

Initially, there was a dense recruitment of M. pyrifera, but the abundance of giant kelp subsequently diminished, resulting in a mix with high densities of understory kelps and abundant bottom cover of fleshy red algae. Red algal cover has declined, and urchin densities have increased slightly in the past few years, particularly in areas with boulders (fig. 6). Fish densities remain moderate.

\section{Dutch Harbor}

The two 50-m transects at the Dutch Harbor supersite are on adjacent, roughly parallel reefs separated by about $140 \mathrm{~m}$ of sand. This supersite is on the south side of the island. Depth along the transects ranges from about 11 to $13 \mathrm{~m}$, and the TidbiT ${ }^{\circledR}$ logger is at approximately $11 \mathrm{~m}$ at the East Dutch Harbor subsite. The swaths traverse high-relief reefs up to $4 \mathrm{~m}$ in height with abundant cracks and ledges. The area is exposed to occasional south swell and prevailing west wind. This supersite, remarkable for its high-relief reefs (fig. 7), high densities of fish, and filter feeding invertebrates has remained the most stable of the sites over the long term (Kenner and Tinker, 2018). It has never exhibited urchin "outbreaks" and kelp densities have remained moderate and mixed with many encrusting invertebrates and small holothurians. Many of the fish transects at Dutch Harbor traverse a high-relief reef with a multitude of cracks, crevices, and ledges that serve as refuge for a variety of fishes. On most of the west-heading transects, a sharp drop-off and near vertical wall from $6 \mathrm{~m}$ at the reef crest down to $15 \mathrm{~m}$ at the bottom is encountered. The water column above the drop-off is often teeming with high numbers of fish of more than a dozen species; however, the final $10-30 \mathrm{~m}$ at the distal end of these western transects traverse a sand channel that is mostly devoid of fish. Nearly all the fish recorded are seen on only about one half the lengths of these western transects and underscores the incredible productivity of Dutch Harbor's rocky reefs.

\section{Daytona 100}

Located at the southeast side of the island, Daytona 100 is generally flat with some $1-2 \mathrm{~m}$ ledges and boulders. Depths along the transects are about $10-12 \mathrm{~m}$ with the TidbiT ${ }^{\circledR}$ logger at about $10 \mathrm{~m}$. The South Daytona subunit, established in fall 2014, has somewhat higher relief and greater depth than the original Daytona site (northern $50 \mathrm{~m}$ ). The area is exposed to occasional south swell. The prevailing wind blows offshore, so wind waves are usually small. The original Daytona site first became a purple urchin barren in the mid-1990s. After a few years, it returned to an algal-dominated state but again changed to an urchin barren soon after. Since that time, it has retained patches of urchin-dominated areas intermixed with patches of kelp-dominated areas (fig. 8). Moderate to high fish densities are typical here. The three east-heading fish transects at this site begin in an urchin barren but continue through

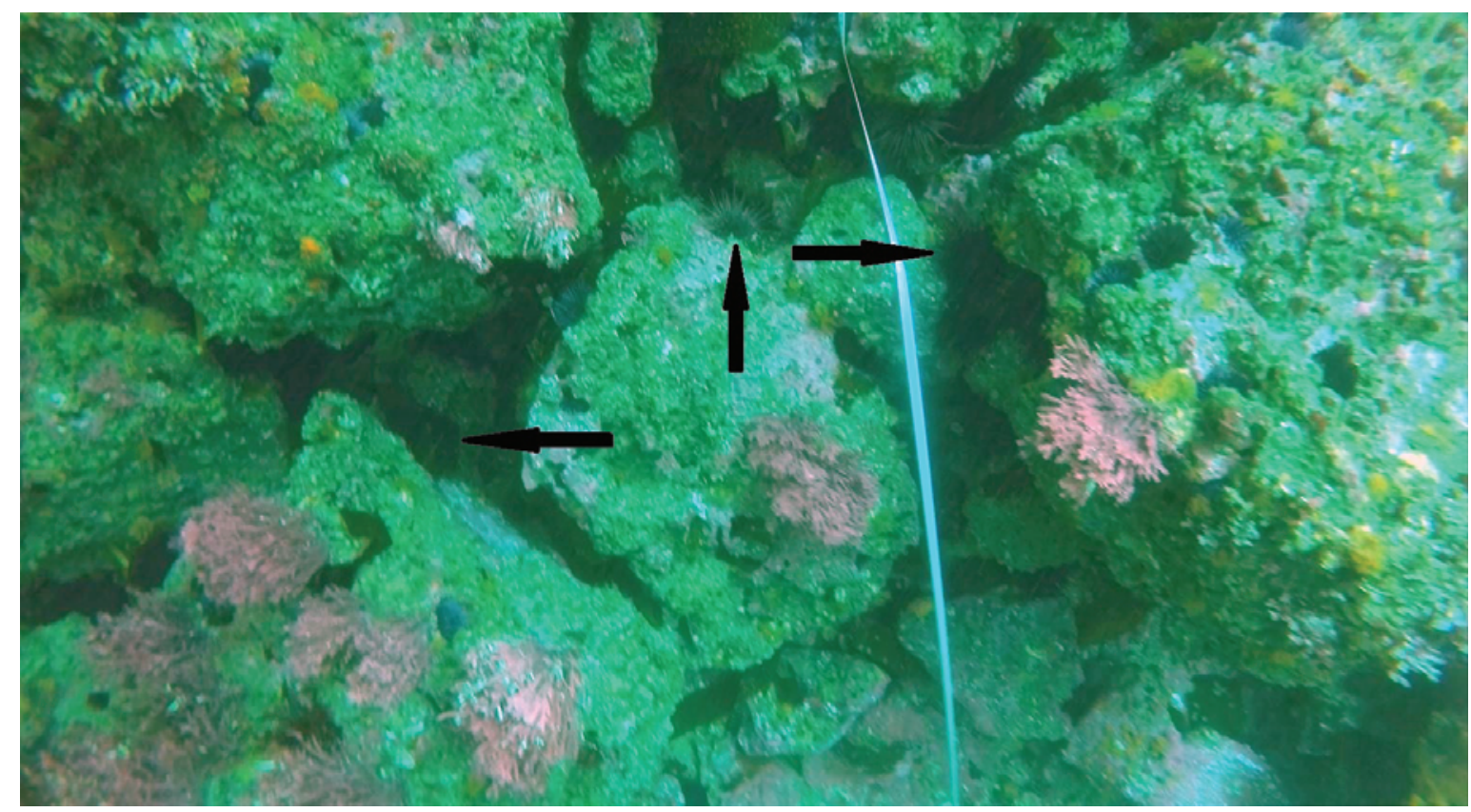

Figure 6. West End supersite showing boulder substrate with urchins in cracks, 0ctober 2019 (captured from video by Shannon Myers). Arrows indicate a few of the many urchins in the photograph. 


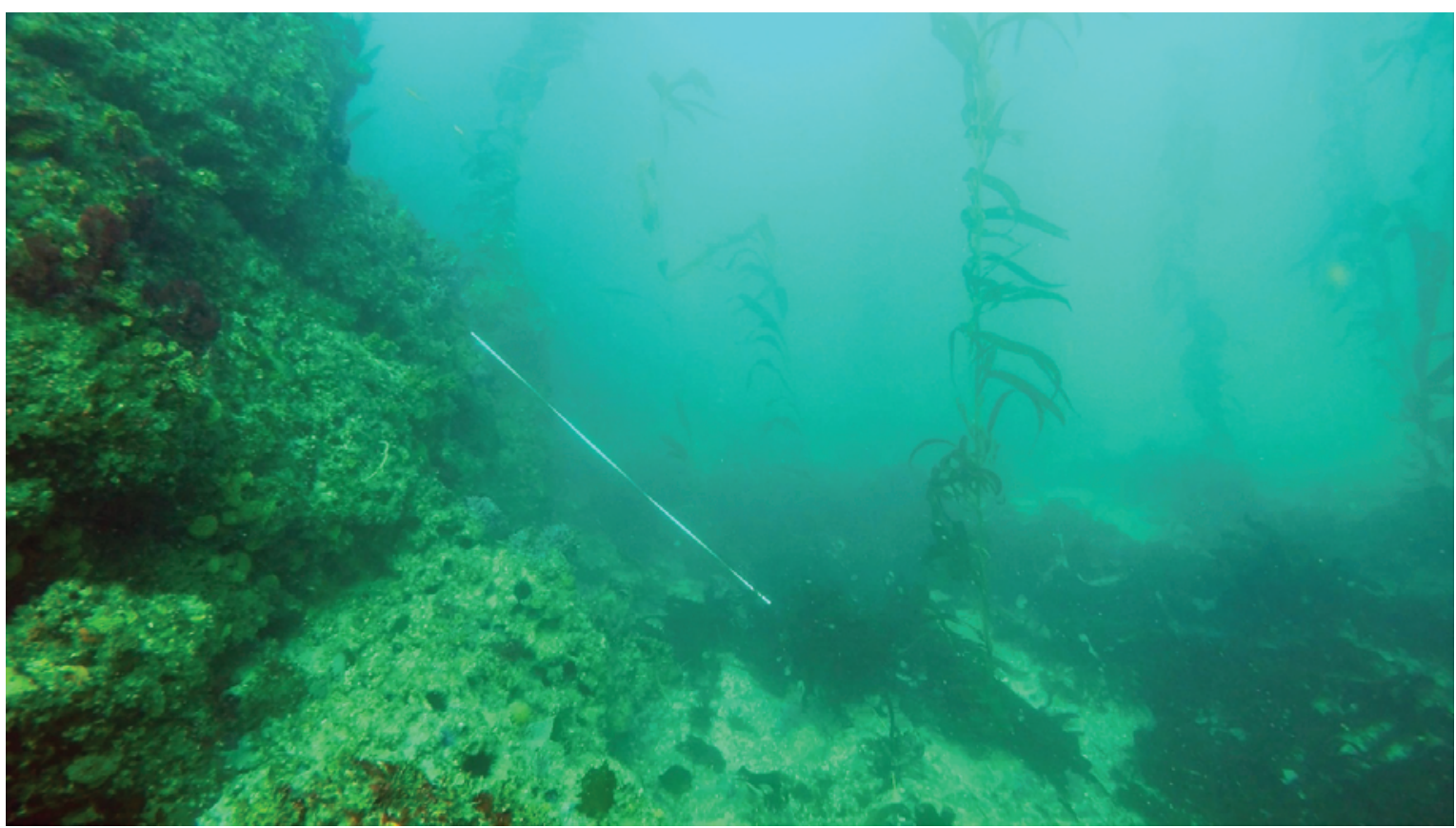

Figure 7. High reef topography at Dutch Harbor, October 2019 (captured from video by Shannon Myers).

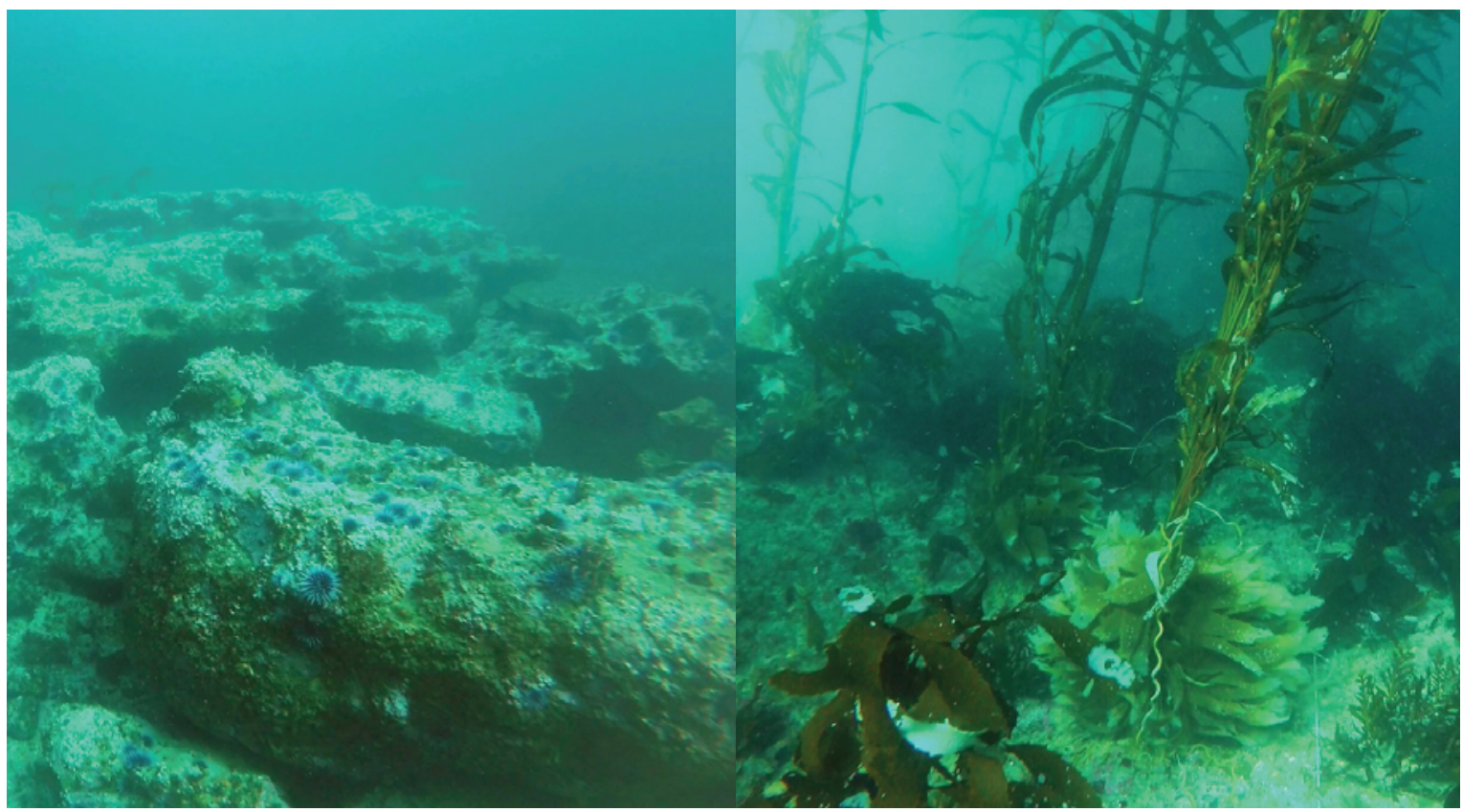

Figure 8. Daytona 100 supersite, 0 ctober 2019, showing urchin dominated (left) and kelp dominated (right) areas (captured from video by Shannon Myers).

an area of flat bottom but kelp-rich habitat, which typically features few fish. The final $10 \mathrm{~m}$ of these transects incorporate a high-relief reef, where most fish are observed. In the early 1980 s, there was considerable sand movement at this site, probably resulting from the old barge landing operation which, prior to construction of the pier, required heavy equipment to move beach sand to enable vehicles to drive off the barge. Sand movement is less apparent since completion of the pier in 2005 . 


\section{Results}

\section{Trip Conditions and Accomplishments}

The fall 2019 trip took place October 1-5. Though initially windy, surface conditions calmed after the first day and the swell remained moderate, resulting in generally good diving conditions. Despite some tidally driven currents, surge was mostly moderate and visibility good, ranging from 7 to $12 \mathrm{~m}$. Water temperatures for the trip were about 14-18 degrees Celsius $\left({ }^{\circ} \mathrm{C}\right)$. We completed all sampling at the four supersites and downloaded and redeployed the TidbiT ${ }^{\circledR}$ archival temperature logger at each. Macrocystis surface kelp canopies were absent at Nav Fac 100, low at Daytona 100, moderate at Dutch Harbor, and dense at West End.

\section{Island Wide}

The temperatures recorded in 2019 at the sites with the best long-term record, Nav Fac and Dutch Harbor, took on a different profile than the previous decade, with considerably less range apparent than most years (fig. 9). Boxplots of bottom temperatures recorded at the supersites are shown in figure 10. Each box plot is based on a year's worth of temperature data from October 1 to September 30. Only Nav Fac data is available for 2006 through 2010, Dutch Harbor data is shown since 2013 and West End and Daytona data since 2016. Each box represents a complete year, so no plot is shown where there were missing weeks of data. The means at Nav Fac are the highest, approximately 0.3-0.4 degrees higher than those at Dutch Harbor, which is the coldest of the sites. Although temperatures at these two sites have declined since the 2014-15 El Niño, they remained higher than pre-El Niño conditions. In fact, the average annual mean temperature was approximately $0.9^{\circ} \mathrm{C}$ higher in $2017-19\left(15.31{ }^{\circ} \mathrm{C}\right.$ at Nav Fac and $14.95^{\circ} \mathrm{C}$ at Dutch Harbor) than for the years preceding the El Niño (14.45 ${ }^{\circ} \mathrm{C}$ during $2006-13$ at Nav Fac and 14.08 ${ }^{\circ} \mathrm{C}$ during 2013 at Dutch Harbor). Perhaps most striking is the reduced range of temperatures at all sites in the 2019 datathe range between the 25th and 75 th percentile was only about 2 degrees, which is smaller than any previous year for which there is data, except 2010. The range of outliers was reduced as well. Temperature data recorded at three of the supersites from fall 2014 to fall 2019 and at Nav Fac 100 from fall 2015 to fall 2019 are shown in figure 11 (the temperature logger

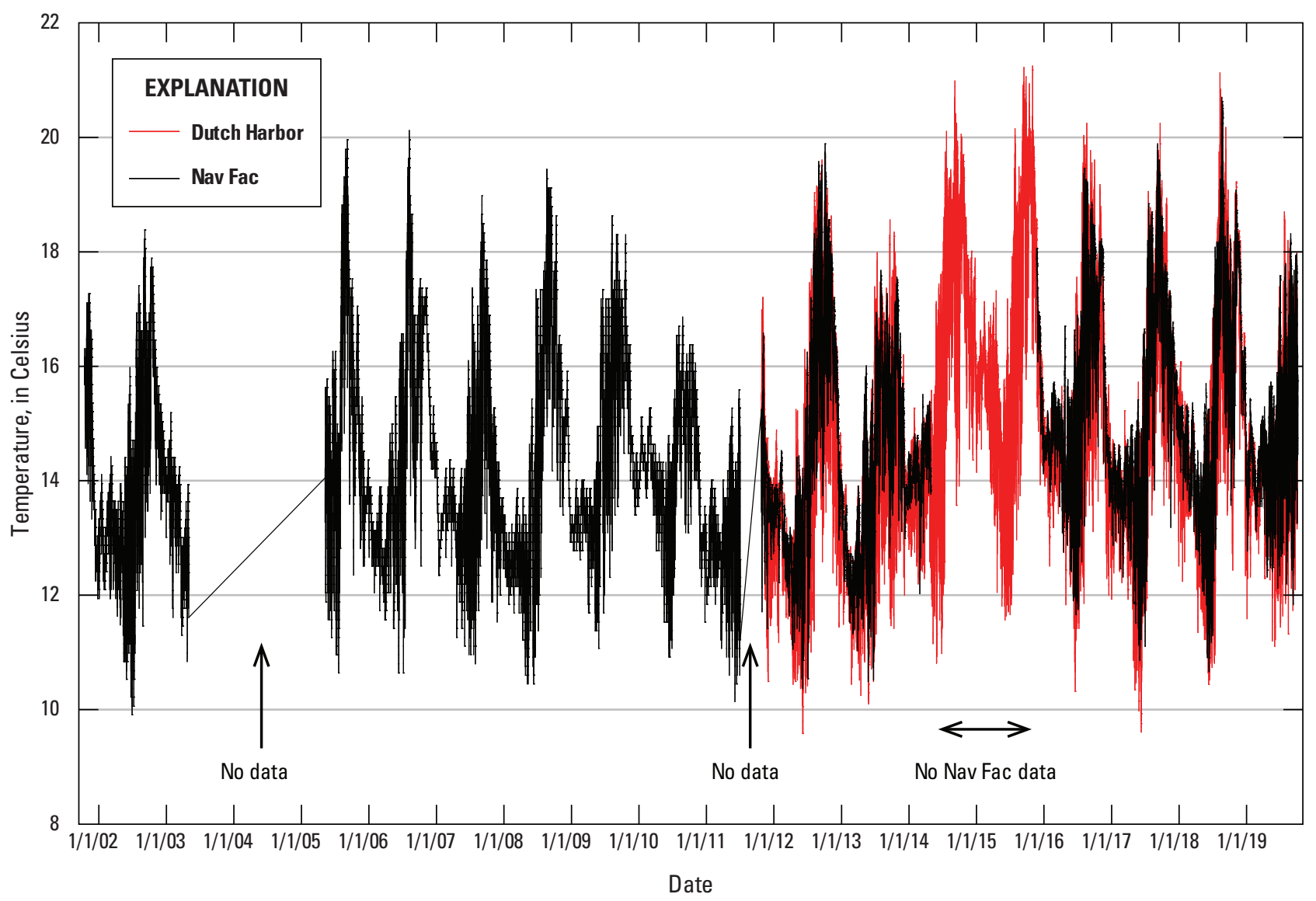

Figure 9. An 18-year temperature record from subtidal readings at San Nicolas Island subtidal sites. Hourly temperature data from Nav Fac at 12-meter depth from October 2001 to October 2019 (in black)—but note periods of missing data—and Dutch Harbor (in red) at 11-m depth from October 2011 to October 2019. 
at Nav Fac 100 was lost after placement in fall 2014 and not replaced until fall 2015). Like in past years, late spring and early summer temperatures fluctuated on the order of $5{ }^{\circ} \mathrm{C}$ during an hour or two, possibly as a result of cold-water upwelling, even though the overall range is clearly diminished.

Counts of the large gastropod Megastraea undosa have increased by an order of magnitude at all the supersites during the last 6 years. They have become particularly numerous at Nav Fac 100 where mean counts now exceed 70 per $20-\mathrm{m}^{2}$ swath. During the last 2-3 years, the density of the fucoid alga C. osmundacea has increased substantially at Nav Fac 100 and at Daytona 100 but this trend was curtailed in the most recent data. Declines in the densities of red and purple sea urchins were seen at all four supersites in fall 2019. Kelp surface canopies were variable among sites, but Nav Fac 100 had no Macrocystis on any swath for the first time in 6 years.

The invasive brown alga, $S$. horneri, was first observed in California at Long Beach Harbor in 2003 and at Catalina Island 3 years later (Miller and others, 2007). By the spring of 2015, S. horneri had been observed at five of the Channel Islands and at several areas along the California coast from Santa Barbara south to Isla Natividad in Baja California (Marks and others, 2015). It was first seen at SNI in low numbers at Nav Fac 100 in fall 2015 (Kenner, 2016) and has been recorded on every subsequent visit there. Typically, relatively low numbers are recorded in fall when plants are small; by spring, counts increase several-fold, and because this annual alga produces copious reproductive fronds, cover

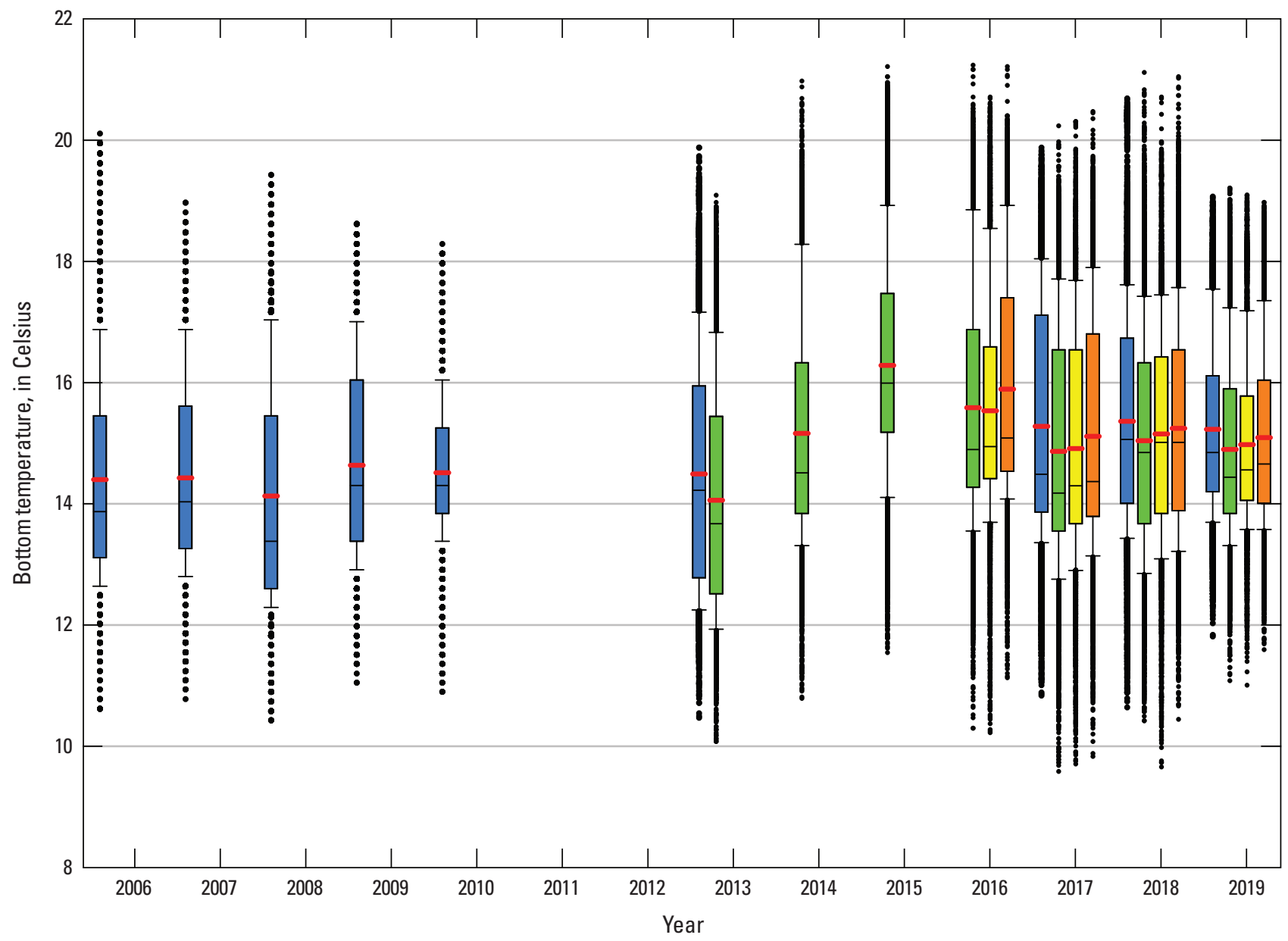

EXPLANATION

$\square$ Nav Fac $\quad \square$ Dutch Harbor $\quad \square$ West End $\quad \square$ Daytona

Figure 10. Box plots of annual bottom temperature at Nav Fac 100 and Dutch Harbor. Because fall 2019 temperatures were collected in early October, temperatures are presented for the period October-September 30 for each year for comparison. Data is only plotted if available for the whole year. The red line is the mean, the black line is the median, the box boundaries designate the 25th and 75th percentiles, and the caps on the whiskers are the 10th and 90th percentile. Outlying points are plotted beyond whisker caps. 

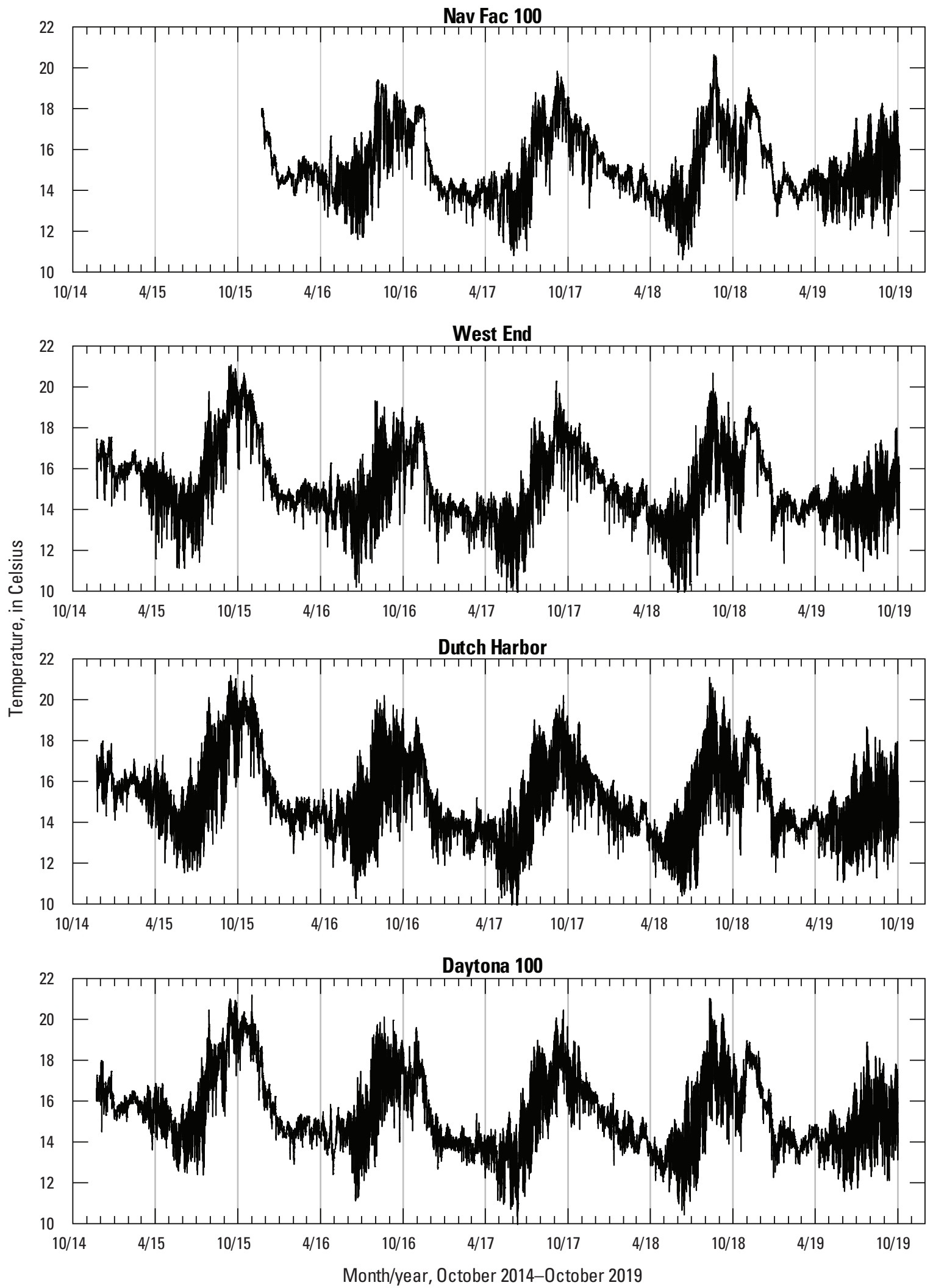

Figure 11. Hourly bottom temperature data for Nav Fac 100 from November 22, 2015 to October 5, 2019, and the other three supersites from November 22, 2014 to October 5, 2019. 
increases dramatically. In spring 2019, however, densities of reproductive plants were considerably lower than the previous two spring seasons, and in fall 2019, densities were lower still — on the order of when first discovered. It is not clear why this decline in density occurred. Sargassum horneri has not been observed at any of the other SNI subtidal monitoring sites but has been seen attached at intertidal sites near Cosign Cove, on the west end of SNI (S. Graham, unpublished data, 2020).

In fall 2019, no abalone (Haliotis spp.) were counted at any of the sites. Only five abalone have been counted since 2002 (four $H$. rufescens and one $H$. corrugata). Before the mid-1990s, island-wide total abalone counts of both species at the original six USGS sites were usually in the teens to low twenties. The timing of their decline corresponded with the decimation of the intertidal black abalone population on SNI by withering syndrome (WS; VanBlaricom and others, 1993), and the disease is known to have affected other abalone species. Because WS was not observed in subtidal habitats at SNI, however, it is possible fishing pressure or other factors may have contributed to the decline. Although sea otters could have played a part in reducing $H$. rufescens and $H$. corrugata density, sea otter numbers and distribution at the time make that unlikely and similar declines were documented throughout Southern California in the absence of sea otters (Rogers-Bennett and others, 2002).

Sea star numbers remained very low, presumably as a result of sea star wasting syndrome (SSWS). Patiria miniata (bat star) densities remained almost unchanged, with the mean of the counts at the four supersites (1.4 per $20-\mathrm{m}^{2}$ swath) still less than half the long-term mean since 1980. Pisaster giganteus (giant sea star) was, again, the only other asteroid counted. A total of 12 were counted at all the supersites and this was the highest count since 2013. No sign of SSWS or sea star recruitment was observed.

During fall 2019, divers estimated the sizes of 2,051 fish and counted 3,122. This was the lowest total for fish counts, including all sites since fall 2011. Table 6 shows minimum, maximum, and average size and the number of fishes sized for each species, pooled from all the sites, in fall 2019. As usual, the schooling species, Chromis punctipinnis (blacksmith) and Oxyjulius californica (señorita), comprised most of these counts.

Table 6. Summary of fall 2019 fish size estimates (centimeters, total length) for all sites combined.

[Min, minimum; Max, maximum; f, female; m, male; - , not applicable]

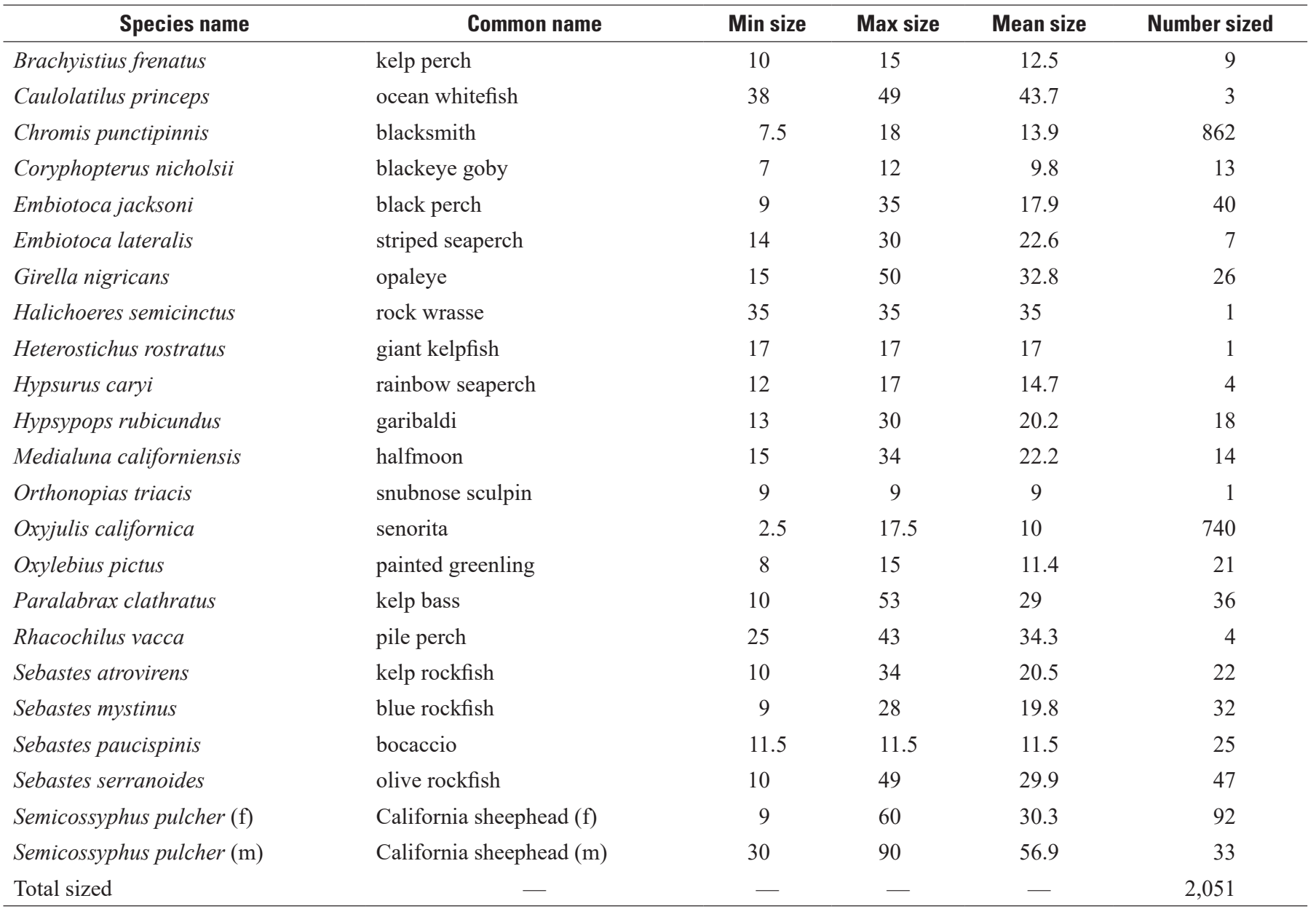


Five $S$. pulcher recruits were observed at the sites in fall 2019. This was the first time since fall 2016 that more than one was counted. In fall 2015, at the height of the last El Niño, 55 juvenile $S$. pulcher were recorded. This important sea urchin predator typically only recruits to SNI during warm water years (Cowen, 1985) when a change in currents in the Southern California Bight supplies larvae to the island. As is common in wrasses, S. pulcher are protogynous hermaphrodites. They change from female to male with age and size, likely as a function of the size and abundance of males in the population (Cowen, 1990). The estimated sizes of $S$. pulcher recorded from all sites around the island between fall 2014 and fall 2019 are plotted by sex in figure 12 . This figure shows recruitment during the first few surveys when warm water (averaging $16.5^{\circ} \mathrm{C}$ and ranging above $21.0^{\circ} \mathrm{C}$ ) was prevalent. In fall 2019 , there were, again, a few individuals less than $10 \mathrm{~cm}$ recorded.

The size structure of the island-wide population of Paralabrax clathratus (kelp bass) remained relatively stable during the last few years (fig. 13). This species also showed recruitment in fall 2014-fall 2015. The last few samples show more individuals in the larger size classes.

\section{Nav Fac 100}

For a second year, Nav Fac 100 supported declining densities of the giant kelp, M. pyrifera, whereas counts of the fucoid alga, C. osmundacea, remained high and numbers of the wavy turban snail, $M$. undosa, continued to increase. Macrocystis densities initially increased somewhat after S. purpuratus densities fell in 2015 (after decades of overgrazing), but by fall 2019, there were no Macrocystis on the transects. Figure 14 shows counts of some of the most dynamic species recorded on the swaths since 2014. The most abundant species continued to be $C$. osmundacea, which declined somewhat from October 2018 but by fall 2019 had increased slightly from the previous spring. Strongylocentrotus purpuratus numbers declined substantially in 2015 but increased somewhat in 2018. Counts were lower during the last three sampling trips but were still two to three times higher than in 2016 and 2017, and they remained the second most common swath-counted organism. Counts of M. undosa continued to increase at the site and it was, again, the third most common of the swath-counted organisms. Pterygophora californica counts, which increased substantially between 2017 and 2018, remained fairly static in recent samples. Fall counts of the invasive algae, S. horneri, generally were lower than spring counts owing to its annual life history but fall 2019 had the lowest fall swath count total since the species was first seen in 2015. Table 7 shows the mean and standard deviation of swath counted organisms for this supersite in fall 2014 through fall 2019.

Figures 15 and 16 show the number of stipes and the holdfast diameters of each M. pyrifera counted on Nav Fac 100 s permanent swaths for the last 11 sampling periods. Both metrics indicated there was poor survival and very little recruitment apparent after fall 2017 , and by fall 2019 , there were no M. pyrifera greater than $1 \mathrm{~m}$ tall on the 10 supersite swaths.

A summary of the invertebrate sizes measured on Nav Fac 100 swaths during the last 11 sampling trips is presented in table 8. Only two of the species, Kelletia kelletii (Kellet's whelk) and $M$. undosa, were sufficiently numerous for analysis, however. There were only three $K$. kelletii counted on the site in fall 2014, but the number increased to 41 in fall 2015 before falling back to low levels again the next spring. Counts remained low until spring 2018, when numbers, again, rose. In fall 2019 , only $10 \mathrm{~K}$. kelletii were counted and they represented a wide range of sizes (fig. 17). It is likely that at least two recruitment events occurred during the 6 years we have collected data on them. It is not clear if the reductions represent mortality or dispersal.

Densities of $M$. undosa have continued to increase at Nav Fac 100 since urchins declined there in 2015. By fall 2019, these snails were 45 times more numerous than they were in fall 2014. The size structure of M. undosa over time (fig. 18) does not give any indication of recruitment pulses driving this increase, with few individuals less than $20 \mathrm{~mm}$ and most of the population ( 96 percent) between 25 and $80 \mathrm{~mm}$ in shell diameter. The fall 2019 size structure shows an increase in the proportion of the sample around $70 \mathrm{~mm}$ and a distinct sawtooth profile relative to the previous sample. The latter could be an artifact resulting from the smaller sample size. Although 724 M. undosa were counted in fall 2019, only the first 279 encountered were measured due to time constraints.

In order to more easily identify changes in the size structure of sea urchins over time or differences among sites, we have summarized the size data for purple and red sea urchins by calculating the percent of each sample in three size bins: one representing recruits up to 1 year of age, one representing the largest individuals, and one size bin in between. Sea urchin growth is variable depending on food quality and availability and physical factors such as spine damage (Ebert, 1968; Kenner, 1992), but a reasonable approximation of first year's growth potential for $S$. purpuratus, in southern California, is $25 \mathrm{~mm}$ (Ebert, 1977; Russell, 1987) and $35 \mathrm{~mm}$ for S. franciscanus (Tegner and Dayton, 1991; Ebert and Russell, 1992). The largest size bin was chosen to represent the oldest urchins and consists, arbitrarily, of the largest 15 percent of each species from the pooled data from all sites and the first 5 years of collections. The middle size bin could represent several cohorts, depending on growth. For purple urchins, these size bins are less than or equal to $25 \mathrm{~mm}, 26-40 \mathrm{~mm}$, and greater than 40 $\mathrm{mm}$ (table 9) and for red urchins, they are less than or equal to $35 \mathrm{~mm}, 36-75 \mathrm{~mm}$, and greater than $75 \mathrm{~mm}$ (table 10).

Strongylocentrotus purpuratus size distribution at Nav Fac 100 showed little change in the last $21 / 2$ years. The size distribution has not shown any sign of a large recruitment event since 2014 (fig. 19). There continued to be a few individuals less than or equal to $10 \mathrm{~mm}$ in diameter, indicating some recruitment in all sampling periods, however. Although small individuals were included in size samples at the rate they 
Sheephead size distribution by sex-all sites

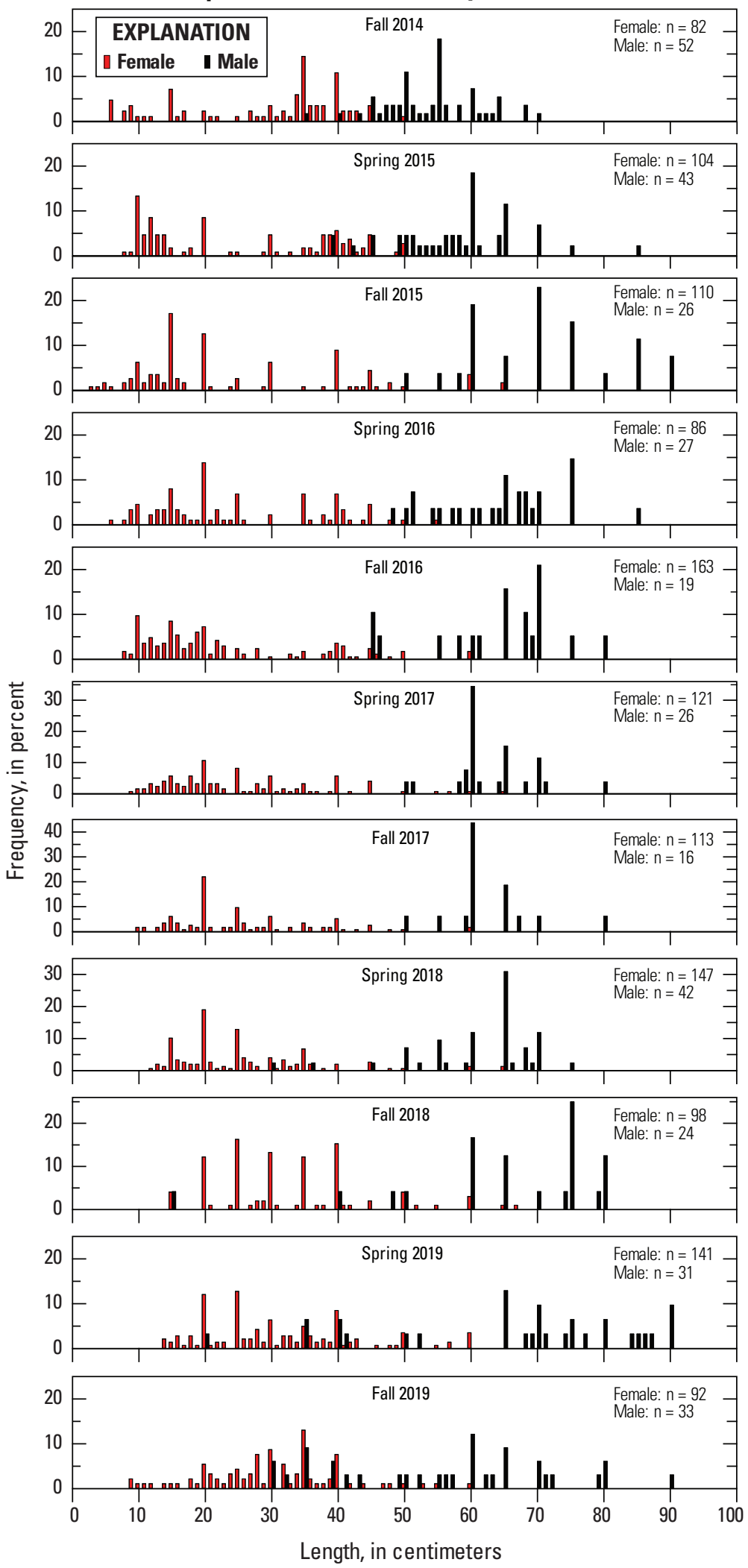

Figure 12. Size distribution, by sex, of Semicossyphus pulcher (sheephead) during fall 2014-fall 2019 (Note different frequency scales. $n=$ number of individuals). 


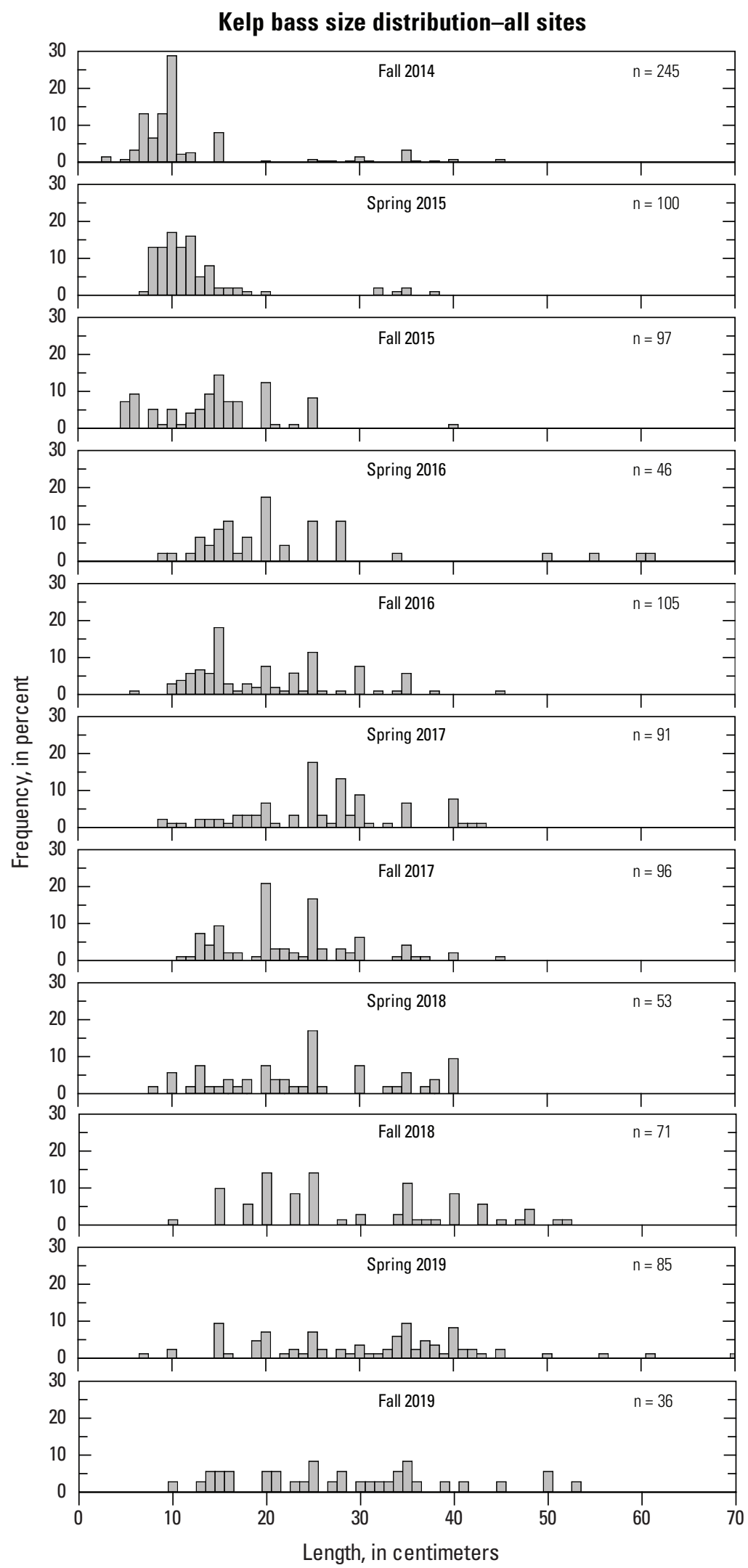

Figure 13. Size distribution of Paralabrax clathratus (kelp bass), fall 2014-fall 2019 ( $\mathrm{n}=$ number of individuals). 
Dynamic swath counted species mean count, in 20 square meters $\left(\mathrm{m}^{2}\right)-\mathrm{Nav}$ Fac 100

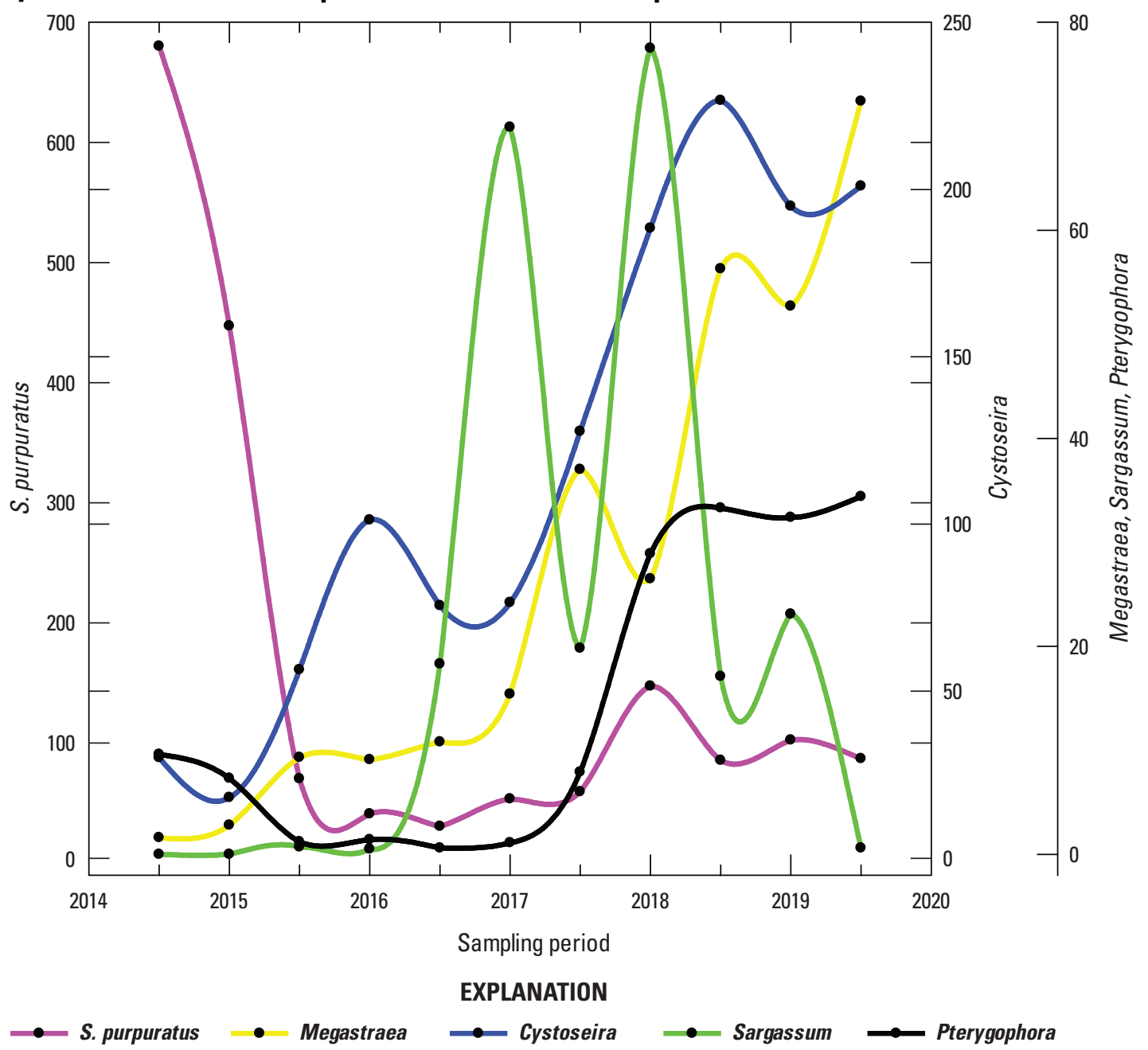

Figure 14. Mean densities of some swath-counted species that have demonstrated changing abundance at Nav Fac 100 from fall 2014 to fall 2019 (note three vertical axes for densities of different species groups). 


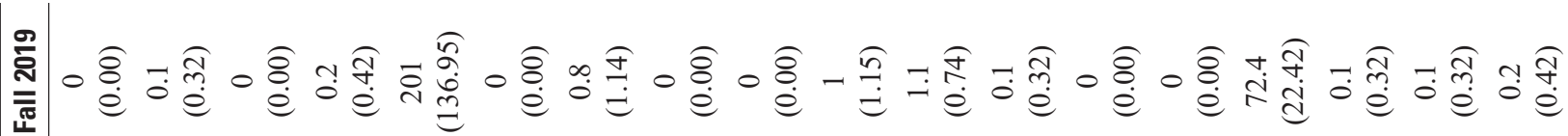

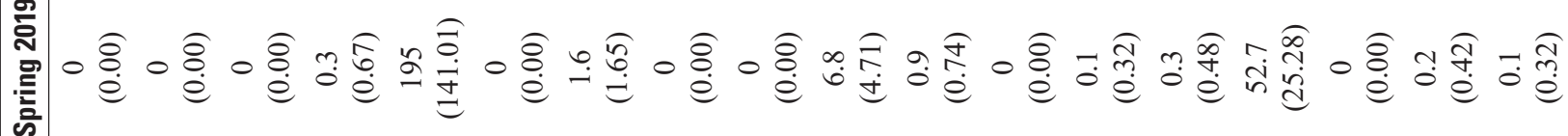

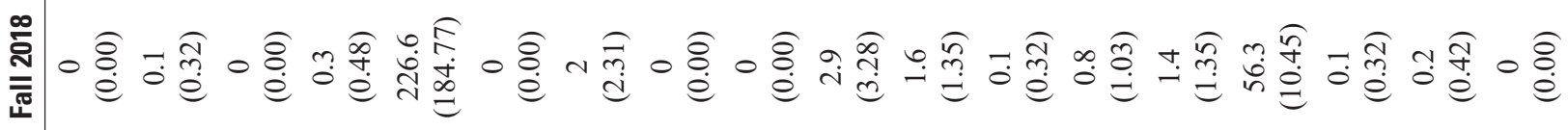

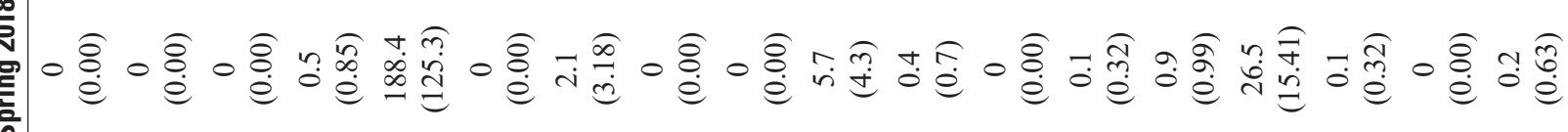

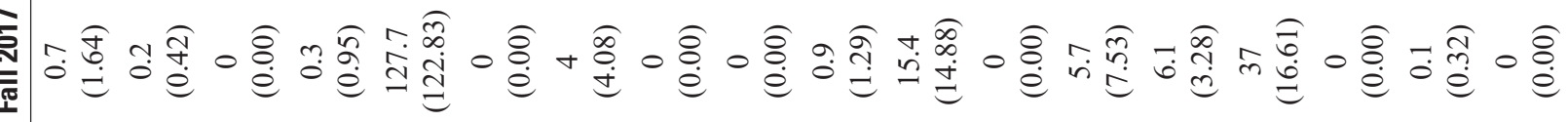

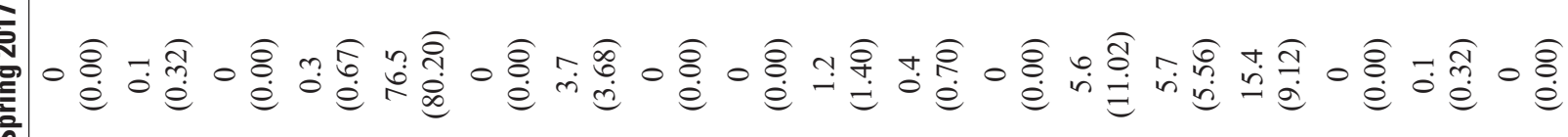

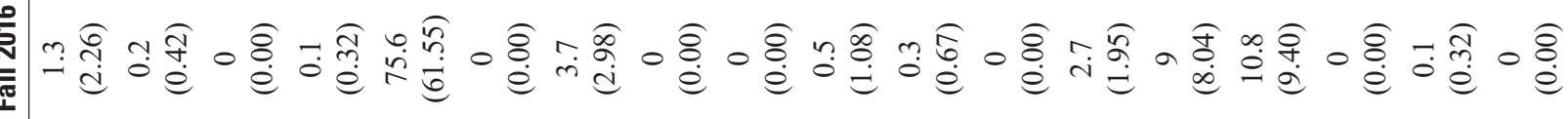

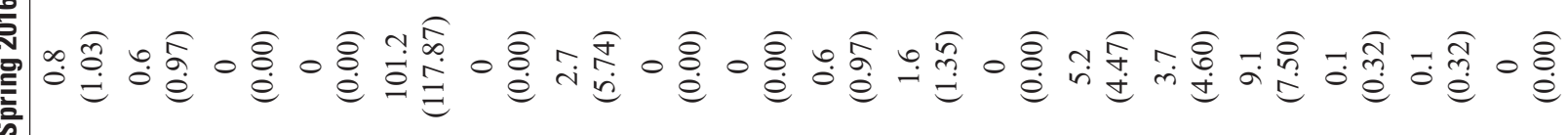

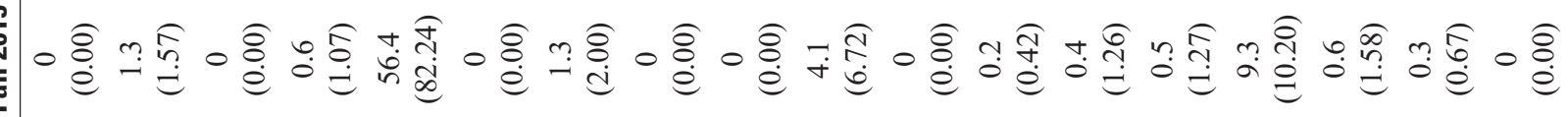

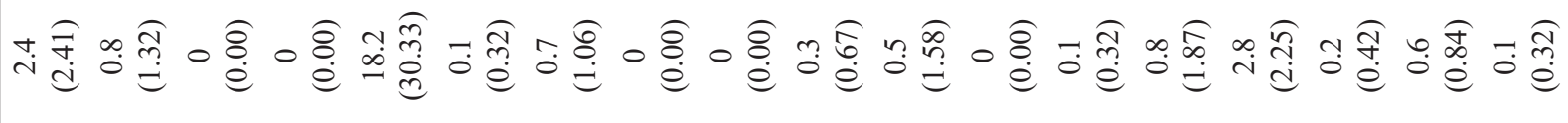

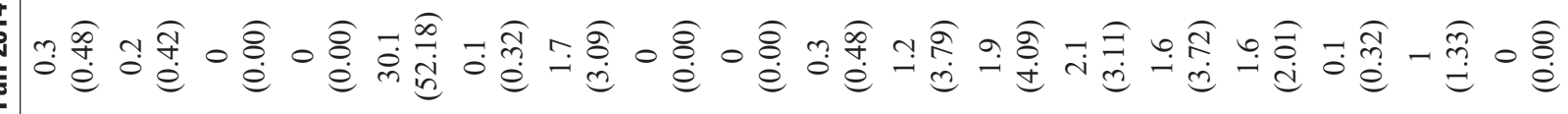




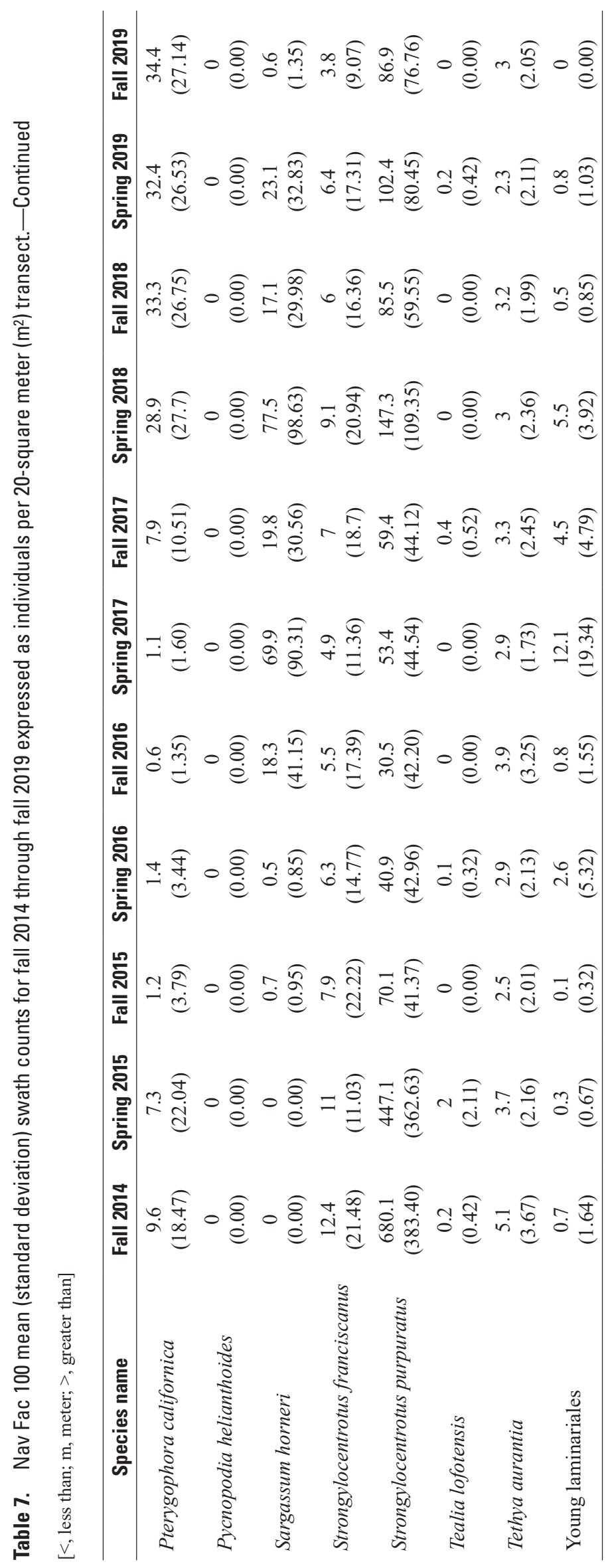




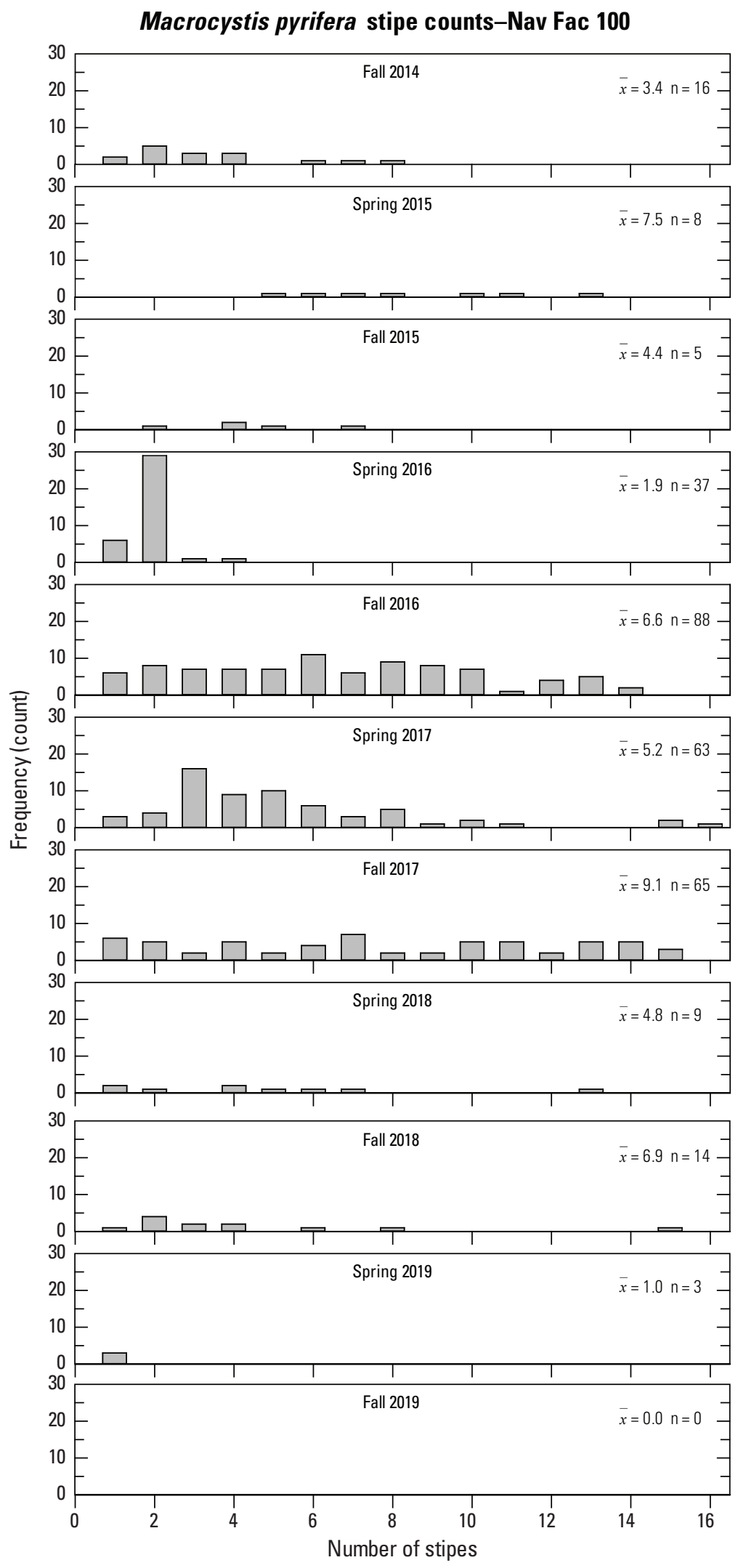

Figure 15. Nav Fac 100 Macrocystis pyrifera (greater than $1 \mathrm{~m}$ tall) stipe counts by season: Fall 2014-fall 2019. 
Macrocystis pyrifera holdfast diameters-Nav Fac 100

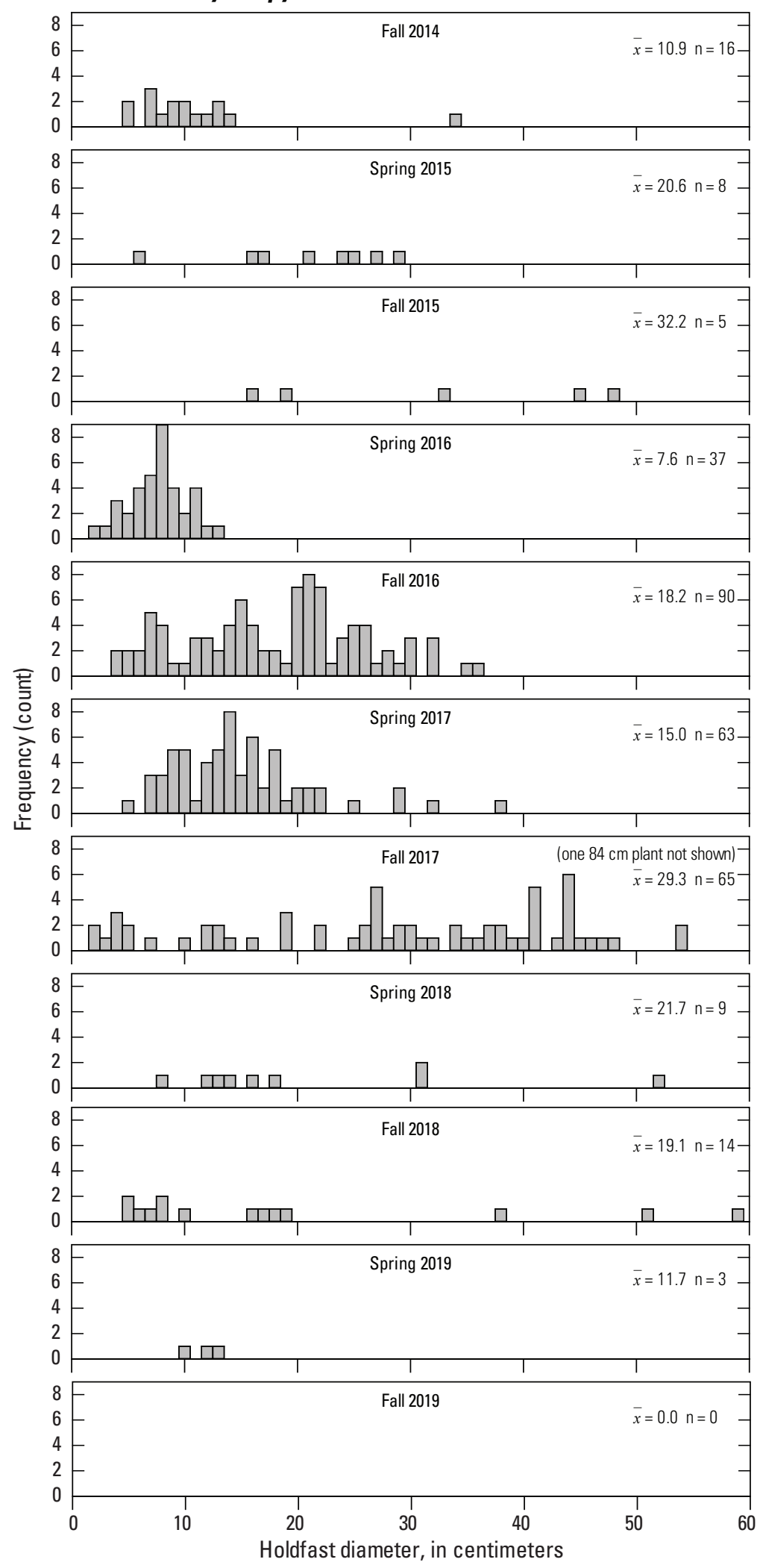

Figure 16. Nav Fac 100 Macrocystis pyrifera (greater than $1 \mathrm{~m}$ tall) holdfast diameters by season: Fall 2014-fall 2019. 
Table 8. Sizes of invertebrates measured on swaths at Nav Fac 100, fall 2014 through fall 2019.

[Strongylocentrotus spp. excluded. See figures 19 and 20 for purple and red urchin size data. Abbreviations: N, sample size; Min, minimum; -, no data; Max, maximum]

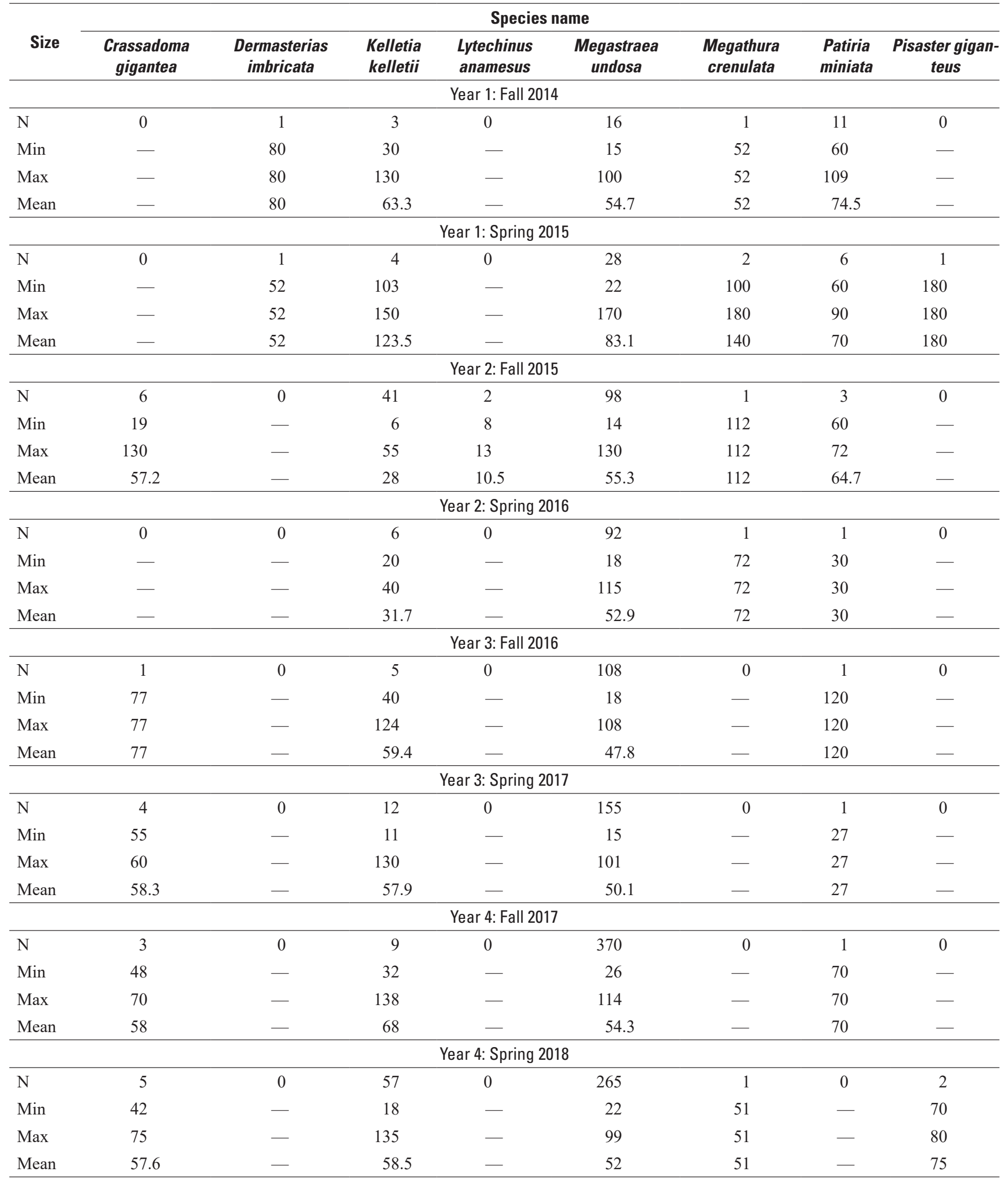


Table 8. Sizes of invertebrates measured on swaths at Nav Fac 100, fall 2014 through fall 2019._-Continued

[Strongylocentrotus spp. excluded. See figures 19 and 20 for purple and red urchin size data. Abbreviations: N, sample size; Min, minimum; -, no data; Max, maximum]

\begin{tabular}{|c|c|c|c|c|c|c|c|c|}
\hline \multirow[b]{2}{*}{ Size } & \multicolumn{8}{|c|}{ Species name } \\
\hline & $\begin{array}{c}\text { Crassadoma } \\
\text { gigantea }\end{array}$ & $\begin{array}{c}\text { Dermasterias } \\
\text { imbricata }\end{array}$ & $\begin{array}{r}\text { Kelletia } \\
\text { kelletii }\end{array}$ & $\begin{array}{l}\text { Lytechinus } \\
\text { anamesus }\end{array}$ & $\begin{array}{c}\text { Megastraea } \\
\text { undosa }\end{array}$ & $\begin{array}{c}\text { Megathura } \\
\text { crenulata }\end{array}$ & $\begin{array}{l}\text { Patiria } \\
\text { miniata }\end{array}$ & $\begin{array}{c}\text { Pisaster gigan- } \\
\text { teus }\end{array}$ \\
\hline \multicolumn{9}{|c|}{ Year 5: Fall 2018} \\
\hline $\mathrm{N}$ & 3 & 0 & 29 & 0 & 563 & 1 & 2 & 0 \\
\hline Min & 43 & - & 32 & - & 19 & 110 & 64 & - \\
\hline \multicolumn{9}{|c|}{ Year 5: Spring 2019} \\
\hline $\mathrm{N}$ & 3 & 0 & 64 & 0 & 528 & 0 & 2 & 1 \\
\hline Min & 48 & - & 24 & - & 19 & - & 61 & 104 \\
\hline Max & 71 & - & 153 & - & 121 & - & 81 & 104 \\
\hline Min & 60 & - & 32 & 10 & 26 & 100 & 55 & 71 \\
\hline $\operatorname{Max}$ & 81 & - & 102 & 10 & 92 & 100 & 55 & 120 \\
\hline Mean & 70.5 & - & 72.4 & 10 & 53.5 & 100 & 55 & 95.5 \\
\hline
\end{tabular}



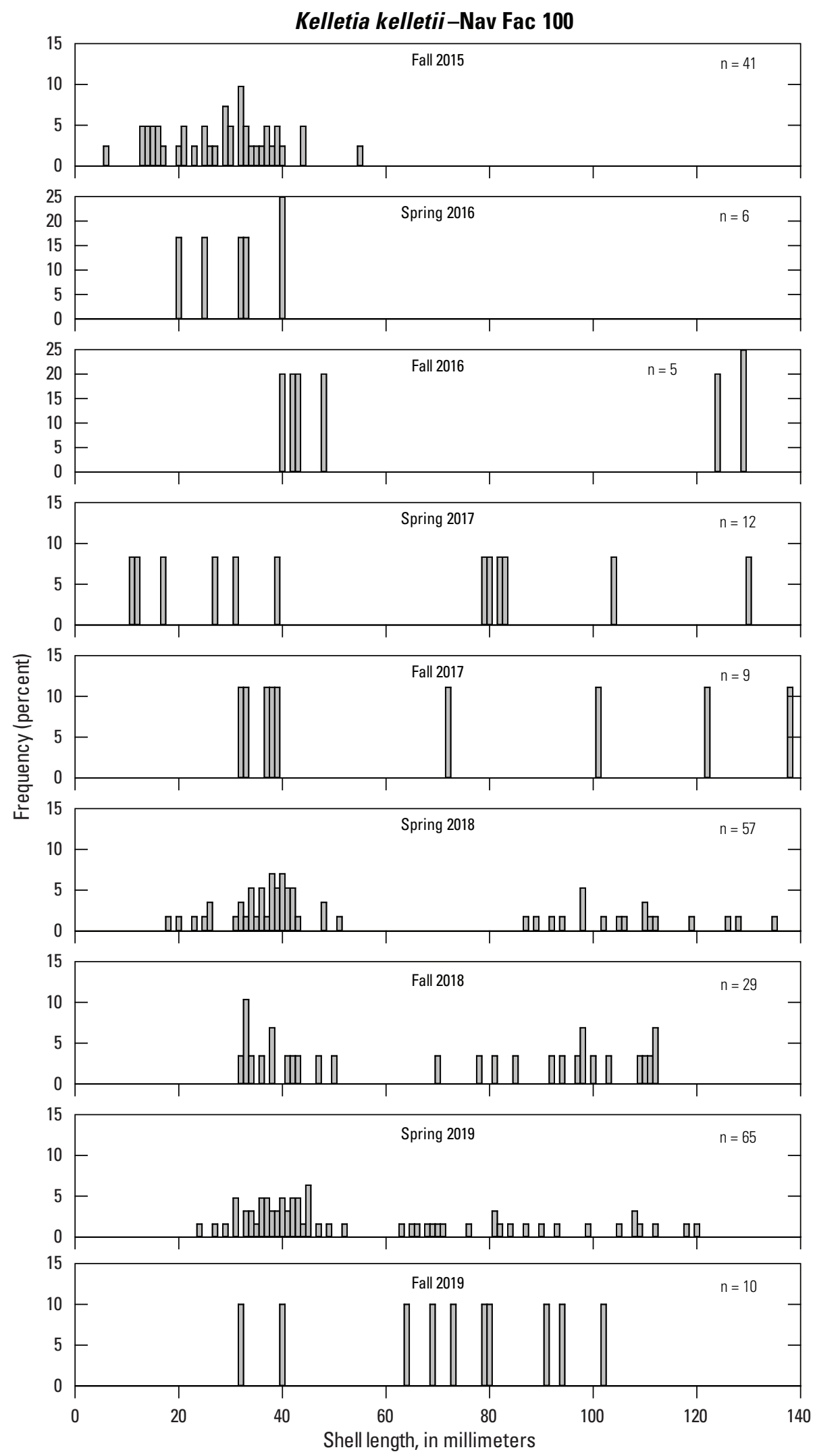

Figure 17. Size structure of Kelletia kelletii (Kellet's whelk) at Nav Fac 100 fall 2015-fall 2019 ( $n=$ number of individuals). 
Megastraea undosa-Nav Fac 100

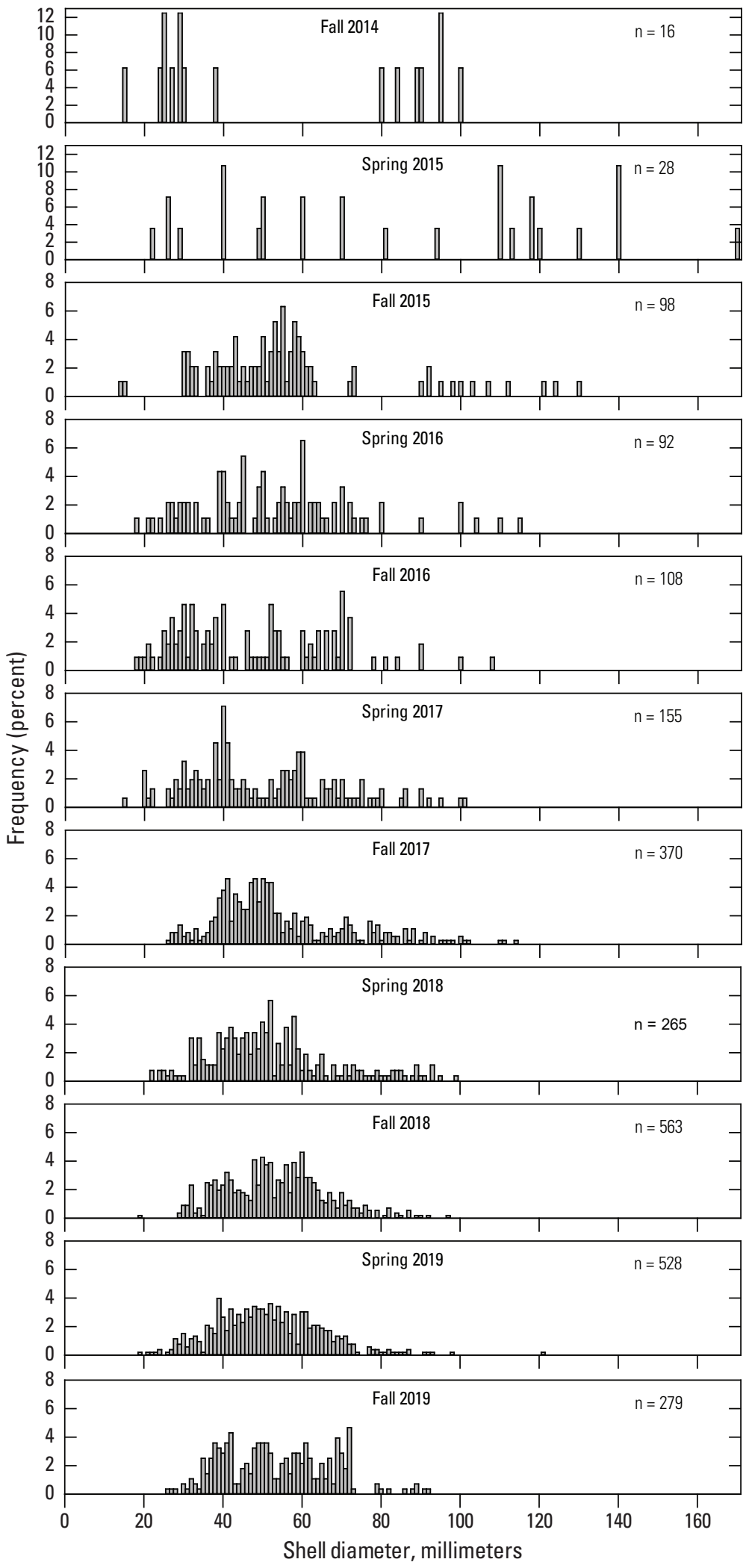

Figure 18. Nav Fac 100 size structure of Megastraea undosa (wavy turban snails) in fall 2014-fall 2019 (Note different frequency scales. $n=$ number of individuals). 
Table 9. Percent Strongylocentrotus purpuratus in three size bins (test diameter-millimeter) at each supersite fall $2014-\mathrm{fall} 2019$.

$[\leq$, less than or equal to; $>$, greater than $]$

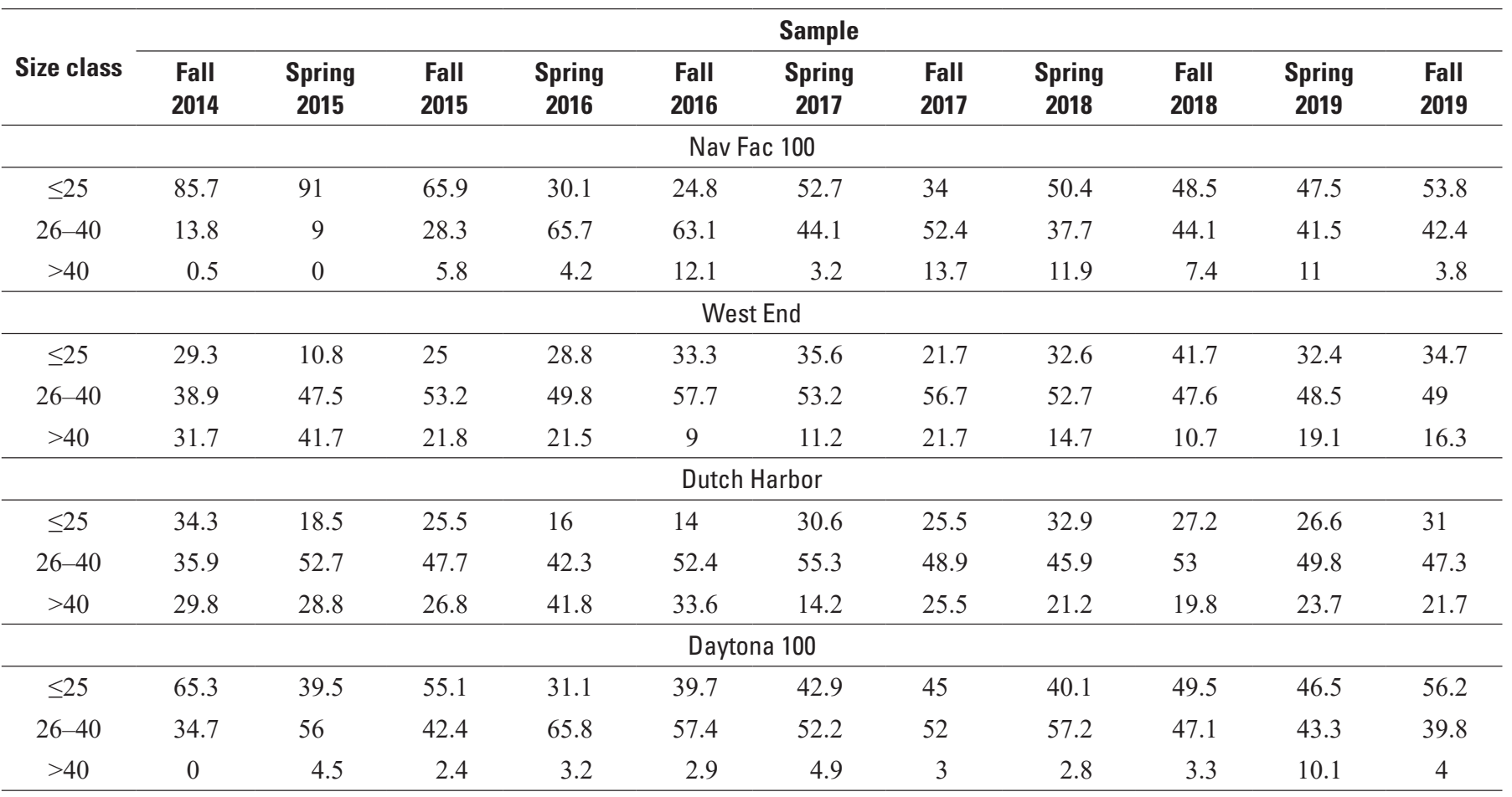

Table 10. Percent Strongylocentrotus franciscanus in three size bins (test diameter-millimeter) at each supersite fall 2014-fall 2019. $[\leq$, less than or equal to; $>$, greater than]

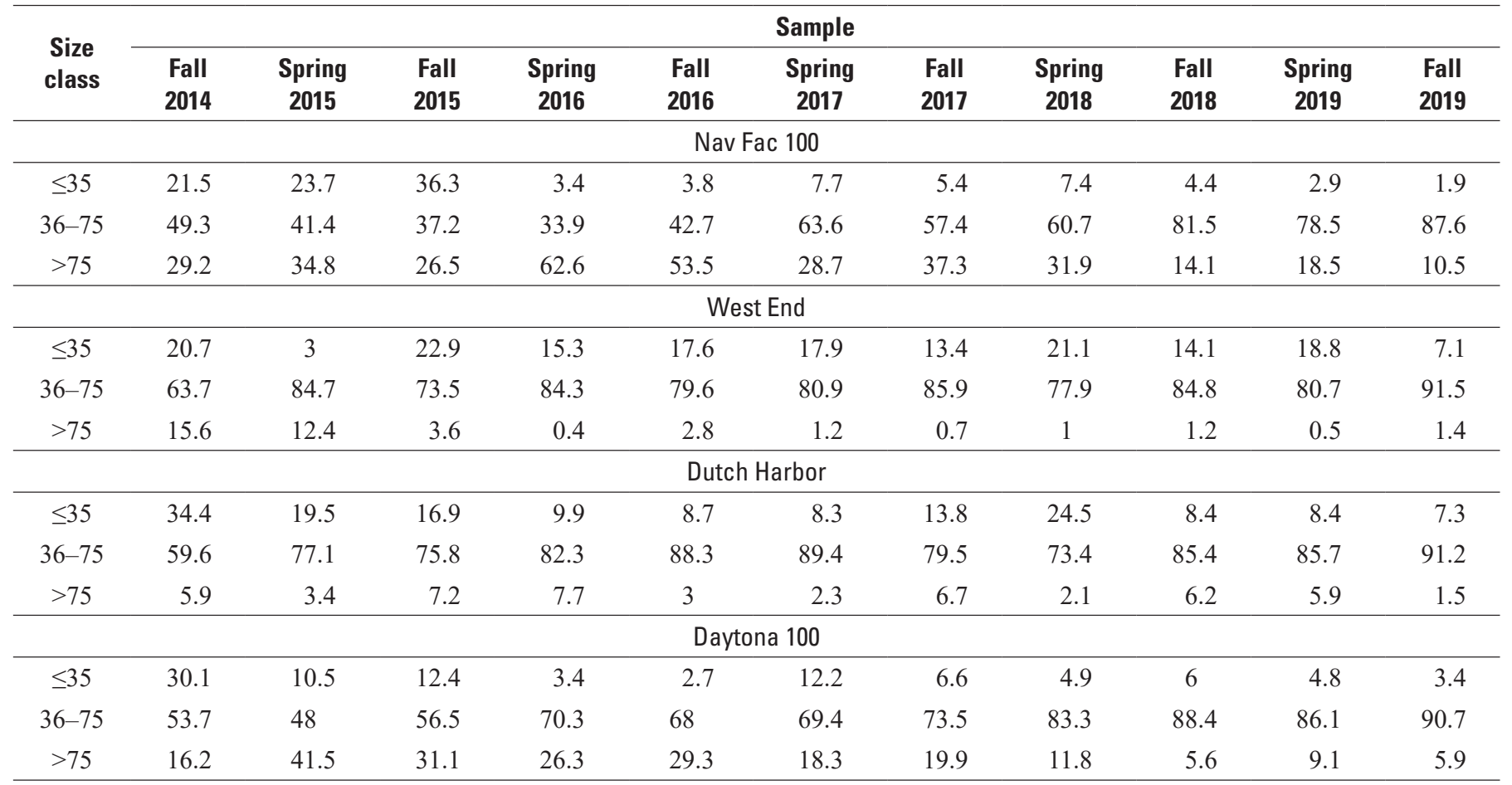


Strongylocentrotus purpuratus-Nav Fac 100

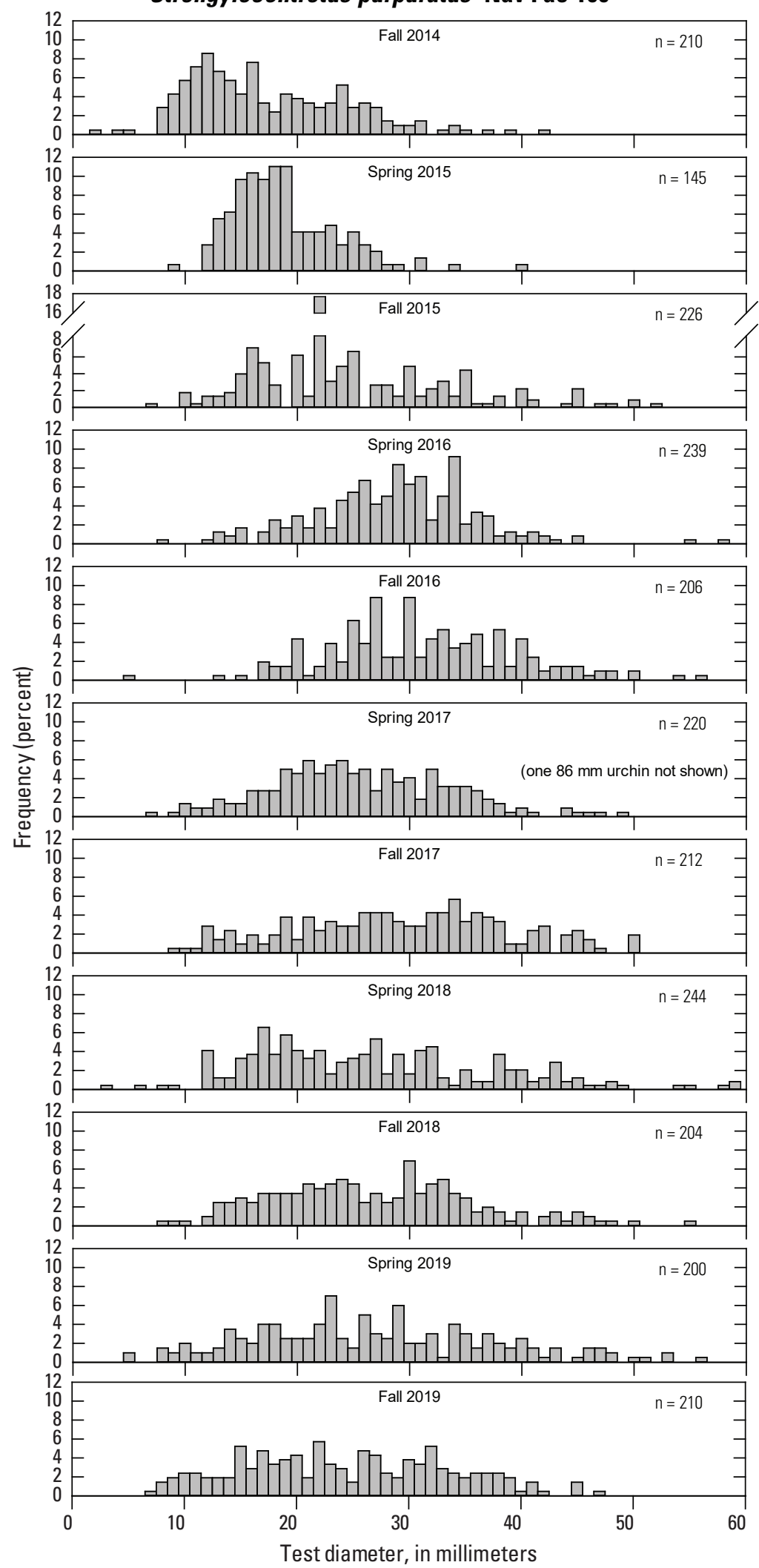

Figure 19. Nav Fac 100 size structure of Strongylocentrotus purpuratus (purple urchins) in fall 2014-fall 2019 (n=number of individuals). 
were encountered, this size class was likely undersampled. Small urchins often take refuge in holdfasts and under rocks, algae, or other invertebrates, which makes any non-destructive sampling methodology biased against them. Table 9 shows that the smallest size bin continued to have the largest proportion of individuals in the most recent four samples. There were very few purple urchins in the largest size bin at this site, making the size distribution most like Daytona 100.

Strongylocentrotus franciscanus mean densities continued to decline at Nav Fac 100, reaching a new low level for the supersite of 3.8 per $20-\mathrm{m}^{2}$ swath. Their size distribution from fall 2019 appeared similar to the preceding two samples (fig. 20), but table 10 indicates the proportions of red urchins in both the largest and smallest size bins have continued to decline. Compared to the other supersites, however, Nav Fac 100 still had the least $S$. franciscanus in the small category and the most in the large category.

The mean numbers of organisms counted in $1-\mathrm{m}^{2}$ quadrats are shown in table 11. Tethya aurantia, the only species consistently counted in the quadrats since fall 2014, continued to be present at low densities. Sargassum horneri declined further, as it did in the swath counts. Total count of this invasive alga in quadrats declined to eight in fall 2019, the lowest since spring 2016.

Cover data collected from RPC quadrats are summarized in figure 21 as categories of cover at the different supersites over time. The fall 2019 distribution is very similar to the previous fall. Although Nav Fac 100 tends to have more exposed bare rock than the other supersites, the proportion of this category gradually diminished after the 2015 decline in purple urchin density. Over the same time span, brown algae (here, a mix of Dictyota binghamiae, Dictyopteris undulata, C. osmundacea, Taonia lennabackerae, and S. horneri) became one of the two dominant cover categories. There was a marked seasonal component to the brown algae cover, with spring cover nearly twice as high as fall. The cover due to S. horneri declined though, and for the second fall in a row, no cover points were scored for this alga.

Encrusting coralline algae, D. binghamiae, and C. osmundacea were the top ranked cover species (table 12). Serpulorbis squamiger (the scaled tube snail) was the most common invertebrate cover species, followed by Astrangia lajollaensis [Astrangia haimei] (brown cup coral).

Nav Fac 100 continued to have the fewest fish species of any of the supersites in fall 2019. This supersite also had the lowest density of fish on midwater and bottom transects, and overall (table 13). The schooling species $O$. californica made up 74 percent of the count, with S. pulcher and P. clathratus making up much of the remainder. Chromis punctipinnis, another schooling species commonly observed at the site, were scarce (table 14).

\section{West End}

The understory kelps, Laminaria spp. and P. californica, remained abundant with little change during the last 5 years at the algal-dominated West End supersite (table 15). Densities of the brown alga, C. osmundacea, declined somewhat, however. Figure 22 shows counts of some of the most dynamic species that were counted on the swaths at this supersite. Strongylocentrotus purpuratus and S. franciscanus have consistently ranked as the first and second most common invertebrate counted on swaths here. Although the densities of $S$. franciscanus remained less than 20 percent of $S$. purpuratus, both followed a very similar trend of increasing densities during the last couple of years, followed by a decline of nearly half between spring and fall of 2019. Megastraea undosa densities climbed in a linear fashion from near zero 3 years ago to the third most common invertebrate in the swath counts at this supersite. The 2019 recruitment of $M$. pyrifera juveniles resulted in a moderate pulse in the "adult" M. pyrifera (those greater than $1 \mathrm{~m}$ tall) with sustained abundance near $0.5 / \mathrm{m}^{2}$ density. This was the highest average density of giant kelp at any of the supersites and was reflected in the surface canopy density.

West End stipe counts and holdfast diameters of $M$. pyrifera plants that are greater than $1 \mathrm{~m}$ tall are plotted in figures 23 and 24. The distributions revealed distinct modes of younger plants apparent in spring 2019, with a slightly older distribution in fall 2019.

Table 16 provides a summary of the sizes of invertebrates measured on swaths at West End for all seasons. Again, $K$. kelletii was the only species observed in all sampling periods at West End. Several other species, including Crassadoma gigantea (rock scallop), P. miniata, and M. undosa, were present in most samples. Figure 25 shows the size distribution of $M$. undosa during the last five sampling trips. The most recent distribution differs from that of Nav Fac 100 (fig. 18), primarily because of the relative lack of individuals less than $40 \mathrm{~mm}$ in diameter.

Like what was reported in the past, there were a few, very small $S$. purpuratus measured at the West End supersite in fall 2019. Although there was not a distinct recruitment mode evident in the size distribution (fig. 26), there were slightly more individuals in the 1-year size class (less than or equal to $25 \mathrm{~mm}$ ) than had been recorded in the previous spring (table 9). The proportions in the S. purpuratus size bins at West End continued to most closely resemble those from Dutch Harbor. Strongylocentrotus franciscanus showed a slight peak in the abundance of less than $20 \mathrm{~mm}$ individuals (fig. 27), but the proportion in the less than or equal to $35-\mathrm{mm}$ size class declined from previous distributions. As a result of this decline, the proportion of the sample in the middle-size classes exceeded 90 percent, and the distribution of size bins closely resembled that at Dutch Harbor (table 10). Although West End continued to have the lowest proportion of large S. franciscanus, Dutch Harbor was very similar and all the supersites showed a decline in this size class from previous 
Strongylocentrotus franciscanus-Nav Fac 100

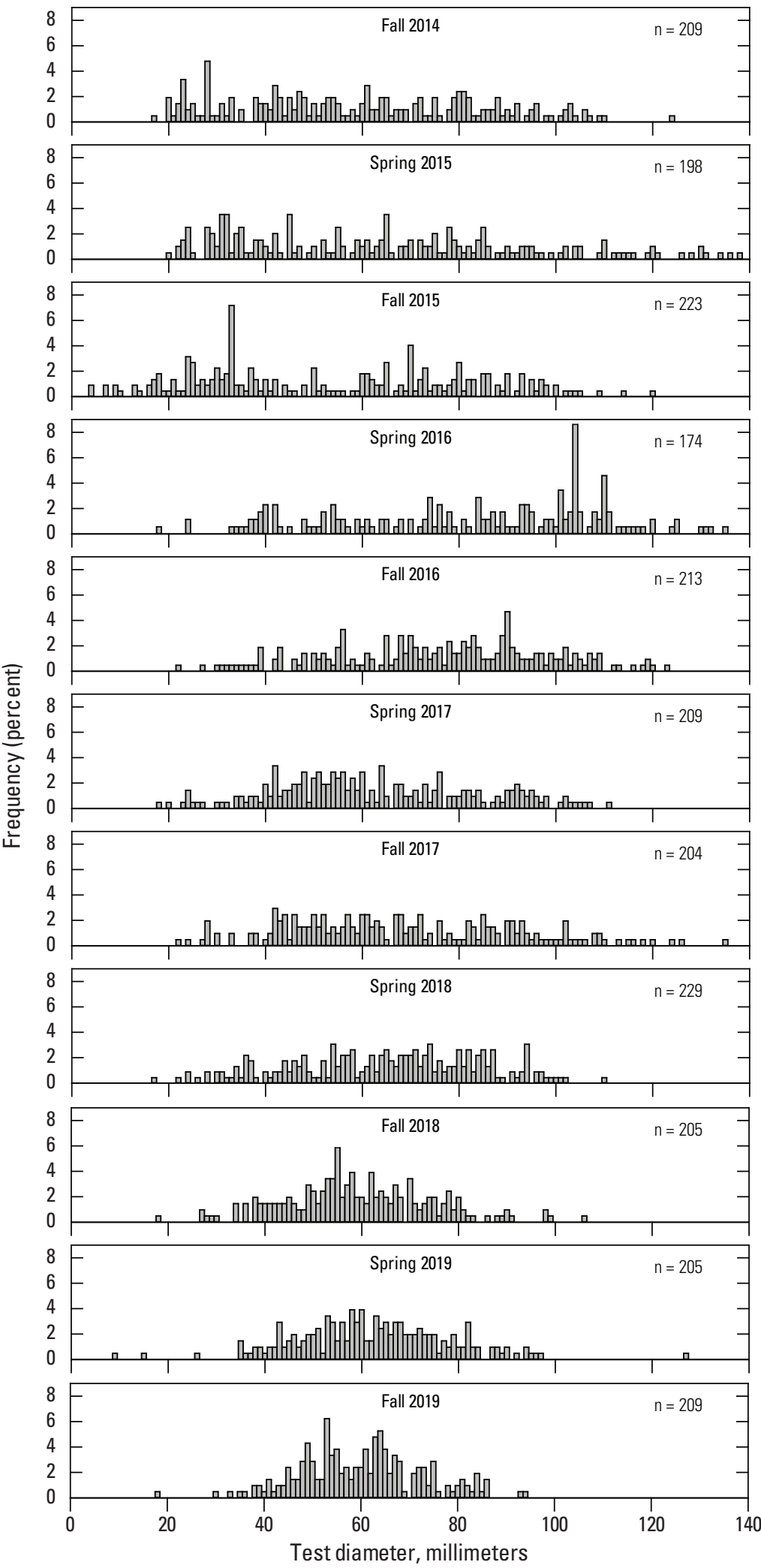

Figure 20. Nav Fac 100 size structure of Strongylocentrotus franciscanus (red urchins) in fall 2014-fall 2019 ( $\mathrm{n}=$ number of individuals). 
Table 11. Nav Fac 100 mean (and standard deviation) of the species counted in twenty 1-m² quadrats for fall 2014 through fall 2019.

\begin{tabular}{|c|c|c|c|c|c|c|c|c|c|c|c|}
\hline Species name & $\begin{array}{l}\text { Fall } \\
2014\end{array}$ & $\begin{array}{c}\text { Spring } \\
2015\end{array}$ & $\begin{array}{l}\text { Fall } \\
2015\end{array}$ & $\begin{array}{c}\text { Spring } \\
2016\end{array}$ & $\begin{array}{l}\text { Fall } \\
2016\end{array}$ & $\begin{array}{c}\text { Spring } \\
2017\end{array}$ & $\begin{array}{l}\text { Fall } \\
2017\end{array}$ & $\begin{array}{c}\text { Spring } \\
2018\end{array}$ & $\begin{array}{l}\text { Fall } \\
2018\end{array}$ & $\begin{array}{c}\text { Spring } \\
2019\end{array}$ & $\begin{array}{l}\text { Fall } \\
2019\end{array}$ \\
\hline $\begin{array}{l}\text { Lithopoma } \\
\text { gibberosa }\end{array}$ & $\begin{array}{c}0 \\
(0.00)\end{array}$ & $\begin{array}{c}0 \\
(0.00)\end{array}$ & $\begin{array}{c}0 \\
(0.00)\end{array}$ & $\begin{array}{c}0 \\
(0.00)\end{array}$ & $\begin{array}{c}0 \\
(0.00)\end{array}$ & $\begin{array}{c}0 \\
(0.00)\end{array}$ & $\begin{array}{c}0 \\
(0.00)\end{array}$ & $\begin{array}{c}0 \\
(0.00)\end{array}$ & $\begin{array}{c}0 \\
(0.00)\end{array}$ & $\begin{array}{c}0 \\
(0.00)\end{array}$ & $\begin{array}{c}0 \\
(0.00)\end{array}$ \\
\hline $\begin{array}{l}\text { Cypraea } \\
\text { spadicea }\end{array}$ & $\begin{array}{c}0 \\
(0.00)\end{array}$ & $\begin{array}{c}0 \\
(0.00)\end{array}$ & $\begin{array}{c}0 \\
(0.00)\end{array}$ & $\begin{array}{c}0 \\
(0.00)\end{array}$ & $\begin{array}{c}0 \\
(0.00)\end{array}$ & $\begin{array}{c}0.1 \\
(0.22)\end{array}$ & $\begin{array}{c}0.1 \\
(0.22)\end{array}$ & $\begin{array}{c}0.1 \\
(0.22)\end{array}$ & $\begin{array}{c}0 \\
(0.00)\end{array}$ & $\begin{array}{c}0.1 \\
(0.22)\end{array}$ & $\begin{array}{c}0 \\
(0.00)\end{array}$ \\
\hline Kelletia kelletii & $\begin{array}{c}0 \\
(0.00)\end{array}$ & $\begin{array}{c}0 \\
(0.00)\end{array}$ & $\begin{array}{c}0.3 \\
(0.80)\end{array}$ & $\begin{array}{c}0 \\
(0.00)\end{array}$ & $\begin{array}{c}0.1 \\
(0.31)\end{array}$ & $\begin{array}{c}0.1 \\
(0.45)\end{array}$ & $\begin{array}{c}0 \\
(0.00)\end{array}$ & $\begin{array}{c}0.1 \\
(0.22)\end{array}$ & $\begin{array}{c}0.2 \\
(0.49)\end{array}$ & $\begin{array}{c}0.1 \\
(0.22)\end{array}$ & $\begin{array}{c}0 \\
(0.00)\end{array}$ \\
\hline Norrisia norrisi & $\begin{array}{c}0 \\
(0.00)\end{array}$ & $\begin{array}{c}0 \\
(0.00)\end{array}$ & $\begin{array}{c}0 \\
(0.00)\end{array}$ & $\begin{array}{c}0.2 \\
(0.49)\end{array}$ & $\begin{array}{c}0.1 \\
(0.22)\end{array}$ & $\begin{array}{c}0.1 \\
(0.31)\end{array}$ & $\begin{array}{c}0 \\
(0.00)\end{array}$ & $\begin{array}{c}0.2 \\
(0.37)\end{array}$ & $\begin{array}{c}0.1 \\
(0.31)\end{array}$ & $\begin{array}{c}0.3 \\
(0.57)\end{array}$ & $\begin{array}{c}0.1 \\
(0.22)\end{array}$ \\
\hline $\begin{array}{l}\text { Sargassum } \\
\text { horneri }\end{array}$ & $\begin{array}{c}0 \\
(0.00)\end{array}$ & $\begin{array}{c}0 \\
(0.00)\end{array}$ & $\begin{array}{c}0.05 \\
(0.22)\end{array}$ & $\begin{array}{c}0 \\
(0.00)\end{array}$ & $\begin{array}{c}4.7 \\
(11.78)\end{array}$ & $\begin{array}{c}6.5 \\
(10.02)\end{array}$ & $\begin{array}{c}3.3 \\
(6.73)\end{array}$ & $\begin{array}{c}4.2 \\
(5.35)\end{array}$ & $\begin{array}{c}2.1 \\
(4.68)\end{array}$ & $\begin{array}{c}1.6 \\
(2.39)\end{array}$ & $\begin{array}{c}0.4 \\
(1.79)\end{array}$ \\
\hline $\begin{array}{l}\text { Styela } \\
\quad \text { montereyensis }\end{array}$ & $\begin{array}{c}0 \\
(0.00)\end{array}$ & $\begin{array}{c}0 \\
(0.00)\end{array}$ & $\begin{array}{c}0 \\
(0.00)\end{array}$ & $\begin{array}{c}0 \\
(0.00)\end{array}$ & $\begin{array}{c}0.2 \\
(0.49)\end{array}$ & $\begin{array}{c}0.1 \\
(0.22)\end{array}$ & $\begin{array}{c}0 \\
(0.00)\end{array}$ & $\begin{array}{c}0 \\
(0.00)\end{array}$ & $\begin{array}{c}0 \\
(0.00)\end{array}$ & $\begin{array}{c}0 \\
(0.00)\end{array}$ & $\begin{array}{c}0 \\
(0.00)\end{array}$ \\
\hline Tethya aurantia & $\begin{array}{c}0.5 \\
(0.69)\end{array}$ & $\begin{array}{c}0.3 \\
(0.55)\end{array}$ & $\begin{array}{c}0.4 \\
(0.59)\end{array}$ & $\begin{array}{c}0.2 \\
(0.52)\end{array}$ & $\begin{array}{c}0.4 \\
(0.67)\end{array}$ & $\begin{array}{c}0.3 \\
(0.44)\end{array}$ & $\begin{array}{c}0.3 \\
(0.44)\end{array}$ & $\begin{array}{c}0.2 \\
(0.37)\end{array}$ & $\begin{array}{c}0.1 \\
(0.31)\end{array}$ & $\begin{array}{c}0.1 \\
(0.22)\end{array}$ & $\begin{array}{c}0.1 \\
(0.31)\end{array}$ \\
\hline Tealia lofotensis & $\begin{array}{c}0 \\
(0.00)\end{array}$ & $\begin{array}{c}0 \\
(0.00)\end{array}$ & $\begin{array}{c}0 \\
(0.00)\end{array}$ & $\begin{array}{c}0 \\
(0.00)\end{array}$ & $\begin{array}{c}0.2 \\
(0.89)\end{array}$ & $\begin{array}{c}0 \\
(0.00)\end{array}$ & $\begin{array}{c}0 \\
(0.00)\end{array}$ & $\begin{array}{c}0 \\
(0.00)\end{array}$ & $\begin{array}{c}0 \\
(0.00)\end{array}$ & $\begin{array}{c}0 \\
(0.00)\end{array}$ & $\begin{array}{c}0 \\
(0.00)\end{array}$ \\
\hline
\end{tabular}



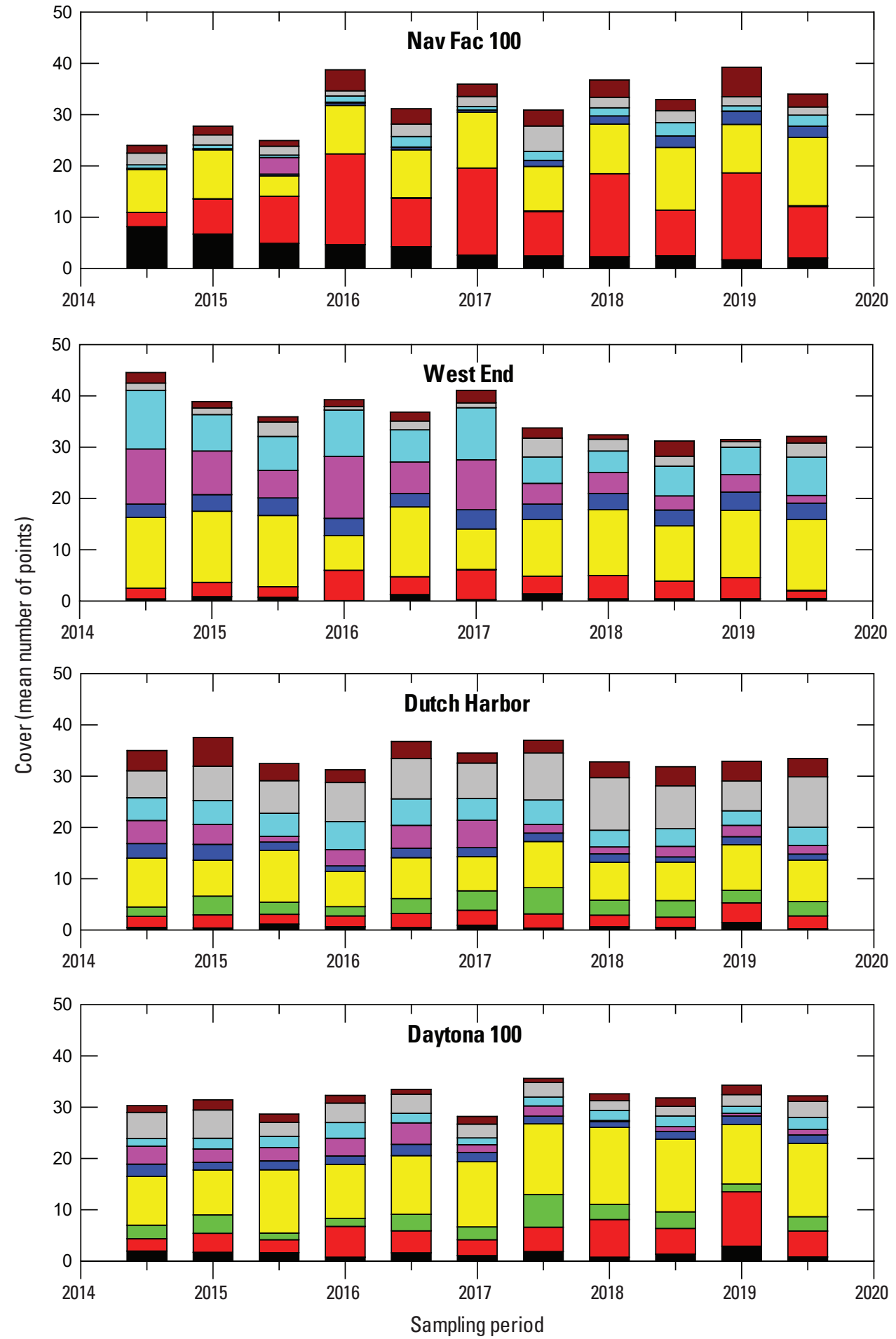

EXPLANATION
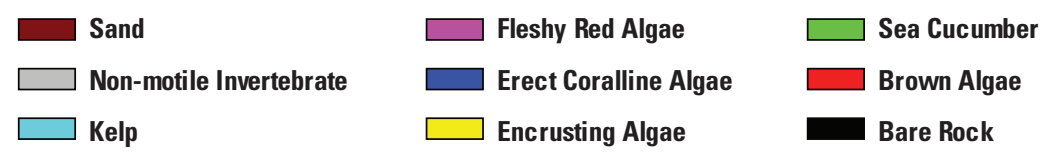

Figure 21. Mean percent cover categories by supersite, fall 2014 through fall 2019. Categories are sand (brown), non-motile invertebrates (gray), kelp (turquoise), fleshy red algae (pink), erect coralline algae (blue), encrusting algae (yellow), sea cucumbers (green), brown algae (non-kelp; red), and bare rock (black). 
Table 12. Nav Fac 100 point contact "species" ranked by the sum of points for fall 2014 through fall 2019.

[>, greater than; $\mathrm{m}$, meter; $<$, less than]

\begin{tabular}{|c|c|c|c|c|c|c|c|c|c|c|c|}
\hline Species name & $\begin{array}{l}\text { Fall } \\
2014\end{array}$ & $\begin{array}{c}\text { Spring } \\
2015\end{array}$ & $\begin{array}{l}\text { Fall } \\
2015\end{array}$ & $\begin{array}{c}\text { Spring } \\
2016\end{array}$ & $\begin{array}{l}\text { Fall } \\
2016\end{array}$ & $\begin{array}{c}\text { Spring } \\
2017\end{array}$ & $\begin{array}{l}\text { Fall } \\
2017\end{array}$ & $\begin{array}{c}\text { Spring } \\
2018\end{array}$ & $\begin{array}{l}\text { Fall } \\
2018\end{array}$ & $\begin{array}{c}\text { Spring } \\
2019\end{array}$ & $\begin{array}{l}\text { Fall } \\
2019\end{array}$ \\
\hline Encrusting coralline algae & 164 & 191 & 79 & 186 & 182 & 218 & 172 & 193 & 237 & 188 & 263 \\
\hline Bare substratum & 163 & 134 & 98 & 93 & 85 & 52 & 49 & 46 & 50 & 34 & 41 \\
\hline Cystoseira osmundacea & 11 & 18 & 39 & 77 & 57 & 68 & 67 & 88 & 107 & 131 & 125 \\
\hline Sargassum horneri & 0 & 0 & 1 & 0 & 8 & 93 & 3 & 95 & 0 & 20 & 0 \\
\hline Corallina officinalis & 4 & 2 & 7 & 6 & 7 & 7 & 16 & 23 & 34 & 32 & 26 \\
\hline Pterygophora californica & 7 & 9 & 5 & 17 & 9 & 5 & 9 & 12 & 28 & 15 & 35 \\
\hline Phragmatopoma californica & 0 & 0 & 0 & 0 & 11 & 21 & 57 & 20 & 19 & 7 & 2 \\
\hline Taonia lennebackerae & 0 & 2 & 0 & 33 & 0 & 23 & 1 & 1 & 0 & 0 & 0 \\
\hline Calliarthron spp. & 1 & 0 & 0 & 3 & 2 & 1 & 2 & 7 & 6 & 13 & 11 \\
\hline Eisenia arborea & 5 & 4 & 0 & 2 & 4 & 4 & 1 & 6 & 8 & 2 & 5 \\
\hline Barnacle & 23 & 15 & 2 & 0 & 0 & 0 & 0 & 0 & 0 & 0 & 0 \\
\hline Kelp holdfast & 0 & 0 & 1 & 0 & 10 & 2 & 14 & 6 & 3 & 1 & 3 \\
\hline Pink encrusting bryozoan & 0 & 0 & 0 & 0 & 2 & 2 & 18 & 3 & 2 & 3 & 4 \\
\hline Mucus tube polychaete & 0 & 2 & 20 & 0 & 9 & 0 & 0 & 0 & 0 & 0 & 0 \\
\hline Macrocystis pyrifera $>1 \mathrm{~m}$ & 0 & 0 & 0 & 0 & 14 & 1 & 7 & 2 & 6 & 0 & 0 \\
\hline Astrangia lajollaensis & 4 & 3 & 0 & 0 & 1 & 3 & 4 & 2 & 1 & 5 & 6 \\
\hline Diopatra ornata & 1 & 1 & 0 & 0 & 3 & 0 & 3 & 3 & 2 & 1 & 3 \\
\hline Orange encrusting sponge & 2 & 2 & 1 & 3 & 1 & 0 & 1 & 0 & 4 & 0 & 0 \\
\hline Filamentous brown algae & 0 & 0 & 0 & 11 & 0 & 0 & 0 & 0 & 0 & 0 & 0 \\
\hline Balanus spp. & 0 & 0 & 0 & 7 & 1 & 0 & 0 & 0 & 2 & 0 & 0 \\
\hline Tethya aurantia & 2 & 1 & 2 & 3 & 0 & 0 & 0 & 1 & 0 & 0 & 0 \\
\hline Diatom film & 8 & 0 & 0 & 0 & 0 & 0 & 0 & 0 & 0 & 0 & 1 \\
\hline Macrocystis pyrifera $<1 \mathrm{~m}$ & 0 & 1 & 2 & 2 & 1 & 1 & 0 & 1 & 0 & 0 & 0 \\
\hline Codium fragile & 0 & 0 & 0 & 0 & 0 & 0 & 2 & 4 & 1 & 0 & 0 \\
\hline Metandrocarpa dura & 0 & 2 & 0 & 0 & 0 & 5 & 0 & 0 & 0 & 0 & 0 \\
\hline Balanophyllia elegans & 2 & 1 & 1 & 0 & 1 & 0 & 0 & 0 & 1 & 0 & 0 \\
\hline Pholad clam & 0 & 3 & 0 & 0 & 2 & 1 & 0 & 0 & 0 & 0 & 0 \\
\hline Spirobranchus spinosus & 0 & 1 & 0 & 0 & 0 & 2 & 0 & 0 & 0 & 3 & 0 \\
\hline Cryptopleura spp. & 0 & 0 & 1 & 3 & 1 & 0 & 0 & 0 & 0 & 0 & 0 \\
\hline Young laminariales & 0 & 0 & 0 & 0 & 1 & 0 & 0 & 3 & 0 & 0 & 0 \\
\hline Lissothuria nutriens & 0 & 0 & 0 & 0 & 0 & 0 & 2 & 0 & 0 & 0 & 1 \\
\hline
\end{tabular}


Table 12. Nav Fac 100 point contact "species" ranked by the sum of points for fall 2014 through fall 2019.—Continued

[ $>$, greater than; $\mathrm{m}$, meter; $<$, less than]

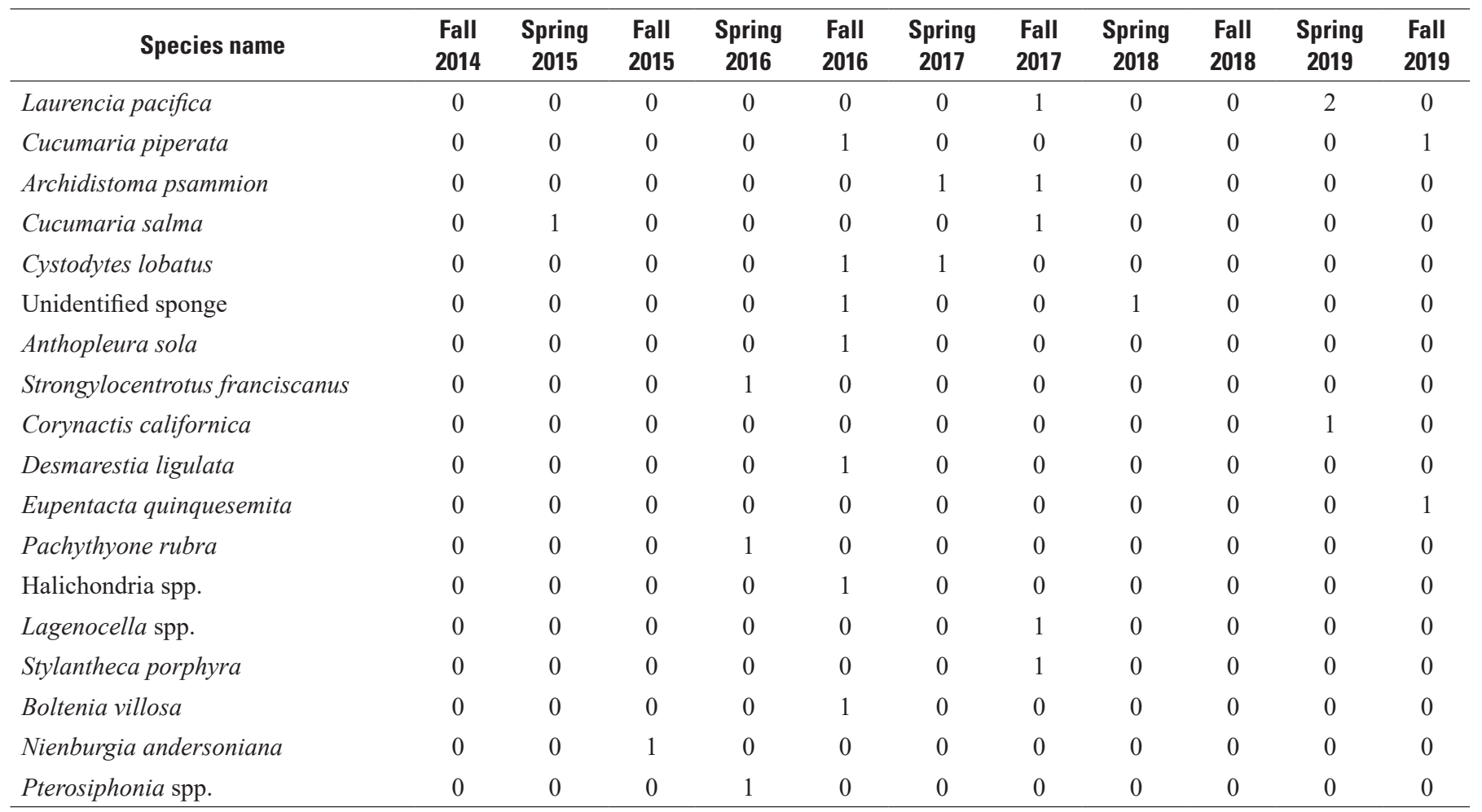


Table 13. Number of fish species counted, total count, and density on benthic and midwater transects, and number of fish sized at each supersite in fall 2014 through fall 2019.

[Densities are given in terms of area rather than volume because the volume of midwater transects is variable. Abbreviation: $\mathrm{m}^{2}$, square meter]

\begin{tabular}{|c|c|c|c|c|c|c|}
\hline \multirow{2}{*}{ Supersite } & \multirow{2}{*}{ Number of species } & \multirow{2}{*}{ Total count } & \multicolumn{3}{|c|}{ Density } & \multirow{2}{*}{ Number sized } \\
\hline & & & Overall $/ \mathrm{m}^{2}$ & Benthic $/ \mathrm{m}^{2}$ & Midwater $/ \mathrm{m}^{2}$ & \\
\hline \multicolumn{7}{|c|}{ Year 1: Fall 2014} \\
\hline West End & 22 & 4022 & 1.15 & 1.15 & 1.15 & 4022 \\
\hline Dutch Harbor & 25 & 8841 & 2.53 & 1.67 & 2.87 & 3148 \\
\hline \multicolumn{7}{|c|}{ Year 1: Spring 2015} \\
\hline Nav Fac 100 & 11 & 136 & 0.08 & 0.27 & 0 & 136 \\
\hline West End & 13 & 958 & 0.27 & 0.05 & 0.36 & 958 \\
\hline Dutch Harbor & 23 & 4503 & 1.3 & 1.43 & 1.23 & 2072 \\
\hline Daytona 100 & 19 & 990 & 0.57 & 0.89 & 0.44 & 990 \\
\hline Dutch Harbor & 27 & 4256 & 1.22 & 1.64 & 1.05 & 1673 \\
\hline Daytona 100 & 16 & 738 & 0.42 & 0.81 & 0.27 & 738 \\
\hline \multicolumn{7}{|c|}{ Year 2: Spring 2016} \\
\hline Nav Fac 100 & 14 & 1067 & 0.61 & 1.22 & 0.37 & 1067 \\
\hline West End & 17 & 1447 & 0.41 & 0.26 & 0.47 & 1447 \\
\hline Dutch Harbor & 29 & 2153 & 0.62 & 0.57 & 0.63 & 947 \\
\hline Daytona 100 & 14 & 336 & 0.19 & 0.31 & 0.15 & 336 \\
\hline \multicolumn{7}{|c|}{ Year 3: Fall 2016} \\
\hline West End & 17 & 1196 & 0.34 & 0.43 & 0.31 & 1196 \\
\hline Dutch Harbor & 20 & 2351 & 0.67 & 0.87 & 0.59 & 1031 \\
\hline Daytona 100 & 15 & 1556 & 0.89 & 0.68 & 0.97 & 1556 \\
\hline \multicolumn{7}{|c|}{ Year 4: Fall 2017} \\
\hline Nav Fac 100 & 11 & 325 & 0.19 & 0.34 & 0.12 & 325 \\
\hline West End & 18 & 303 & 0.09 & 0.22 & 0.03 & 303 \\
\hline Dutch Harbor & 25 & 2441 & 0.7 & 0.7 & 0.7 & 1031 \\
\hline Daytona 100 & 22 & 619 & 0.35 & 0.48 & 0.3 & 619 \\
\hline \multicolumn{7}{|c|}{ Year 4: Spring 2018} \\
\hline Nav Fac 100 & 10 & 702 & 0.4 & 0.58 & 0.33 & 702 \\
\hline West End & 17 & 653 & 0.19 & 0.3 & 0.14 & 653 \\
\hline Dutch Harbor & 22 & 2614 & 0.75 & 0.55 & 0.83 & 1178 \\
\hline Daytona 100 & 14 & 936 & 0.53 & 1.33 & 0.22 & 936 \\
\hline
\end{tabular}


Table 13. Number of fish species counted, total count, and density on benthic and midwater transects, and number of fish sized at each supersite in fall 2014 through fall 2019._-Continued

[Densities are given in terms of area rather than volume because the volume of midwater transects is variable. Abbreviation: $\mathrm{m}^{2}$, square meter]

\begin{tabular}{|c|c|c|c|c|c|c|}
\hline \multirow{2}{*}{ Supersite } & \multirow{2}{*}{ Number of species } & \multirow{2}{*}{ Total count } & \multicolumn{3}{|c|}{ Density } & \multirow{2}{*}{ Number sized } \\
\hline & & & Overall / $\mathrm{m}^{2}$ & Benthic $/ \mathrm{m}^{2}$ & Midwater /m² & \\
\hline \multicolumn{7}{|c|}{ Year 5: Fall 2018} \\
\hline West End & 15 & 523 & 0.15 & 0.18 & 0.14 & 523 \\
\hline Dutch Harbor & 24 & 2201 & 0.63 & 0.63 & 0.63 & 648 \\
\hline \multicolumn{7}{|c|}{ Year 5: Spring 2019} \\
\hline Nav Fac 100 & 10 & 420 & 0.24 & 0.43 & 0.16 & 420 \\
\hline West End & 15 & 339 & 0.1 & 0.2 & 0.05 & 339 \\
\hline Dutch Harbor & 24 & 3494 & 1 & 0.77 & 1.09 & 1924 \\
\hline Daytona 100 & 15 & 1298 & 0.74 & 0.59 & 0.8 & 1298 \\
\hline Dutch Harbor & 24 & 1912 & 0.55 & 0.54 & 0.55 & 841 \\
\hline Daytona 100 & 16 & 356 & 0.2 & 0.39 & 0.13 & 356 \\
\hline
\end{tabular}


Table 14. Nav Fac 100 fish counts_Adult (juvenile)_in fall 2014 through spring 2019 by species.

[f, female; $\mathrm{m}$, male ]

\begin{tabular}{|c|c|c|c|c|c|c|c|c|c|c|c|}
\hline Species name & $\begin{array}{l}\text { Fall } \\
2014 \\
\end{array}$ & $\begin{array}{c}\text { Spring } \\
2015\end{array}$ & $\begin{array}{l}\text { Fall } \\
2015 \\
\end{array}$ & $\begin{array}{c}\text { Spring } \\
2016\end{array}$ & $\begin{array}{l}\text { Fall } \\
2016 \\
\end{array}$ & $\begin{array}{c}\text { Spring } \\
2017 \\
\end{array}$ & $\begin{array}{l}\text { Fall } \\
2017 \\
\end{array}$ & $\begin{array}{c}\text { Spring } \\
2018 \\
\end{array}$ & $\begin{array}{l}\text { Fall } \\
2018 \\
\end{array}$ & $\begin{array}{c}\text { Spring } \\
2019 \\
\end{array}$ & $\begin{array}{l}\text { Fall } \\
2019 \\
\end{array}$ \\
\hline Artedius spp. & 0 & 1 & 0 & 0 & 0 & 0 & 0 & 0 & 0 & 0 & 0 \\
\hline $\begin{array}{c}\text { Caulolatilus } \\
\text { princeps }\end{array}$ & 3 & 0 & 2 & 0 & 0 & 0 & 0 & 0 & 0 & 0 & 1 \\
\hline $\begin{array}{l}\text { Coryphopterus } \\
\text { nicholsii }\end{array}$ & 57 & 1 & 5 & 0 & 4 & 1 & 3 & 9 & 1 & 5 & 4 \\
\hline Embiotoca jacksoni & 12 & 7 & 4 & 7 & 3 & 11 & 9 & 0 & 15 & 7 & 6 \\
\hline Embiotoca lateralis & 2 & 0 & 0 & 0 & 0 & 0 & 0 & 0 & 0 & 0 & 0 \\
\hline $\begin{array}{l}\text { Heterodontus } \\
\text { francisci }\end{array}$ & 0 & 0 & 0 & 0 & 0 & 1 & 0 & 0 & 0 & 0 & 0 \\
\hline Hypsurus caryi & 5 & 0 & 0 & 0 & 6 & 0 & 0 & 0 & 0 & 2 & 1 \\
\hline $\begin{array}{l}\text { Hypsypops } \\
\text { rubicundus }\end{array}$ & 1 & 1 & 2 & 1 & 8 & 6 & 4 & 1 & 4 & 5 & 1 \\
\hline $\begin{array}{l}\text { Medialuna } \\
\quad \text { californiensis }\end{array}$ & 0 & 0 & 35 & 16 & 3 & 1 & 37 & 1 & 0 & 1 & 0 \\
\hline Neoclinus spp. & 0 & 0 & 0 & 0 & 1 & 0 & 0 & 0 & 0 & 0 & 0 \\
\hline $\begin{array}{l}\text { Sebastes } \\
\quad \text { chrysomelas }\end{array}$ & 3 & 0 & 0 & 1 & 0 & 0 & 0 & 0 & 0 & 0 & 0 \\
\hline Sebastes mystinus & 4 & 0 & 0 & 1 & 2 & 2 & 0 & 0 & 1 & 0 & 0 \\
\hline Sebastes rastrelliger & 0 & 0 & 0 & 1 & 0 & 0 & 0 & 0 & 0 & 0 & 0 \\
\hline $\begin{array}{l}\text { Sebastes } \\
\quad \text { serranoides }\end{array}$ & 0 & 3 & 0 & 0 & 1 & 0 & 0 & 0 & 0 & 0 & 1 \\
\hline Sebastes serriceps & 1 & 0 & 0 & 0 & 0 & 1 & 0 & 0 & 0 & 0 & 0 \\
\hline $\begin{array}{l}\text { Semicossyphus } \\
\text { pulcher (f) }\end{array}$ & 17 & $\begin{array}{c}2 \\
(1)\end{array}$ & $\begin{array}{l}23 \\
(3)\end{array}$ & $\begin{array}{l}15 \\
(2)\end{array}$ & $\begin{array}{l}32 \\
(6)\end{array}$ & 21 & 20 & 35 & 19 & 27 & 9 \\
\hline $\begin{array}{l}\text { Semicossyphus } \\
\text { pulcher }(\mathrm{m})\end{array}$ & 3 & 1 & 4 & 4 & 1 & 1 & 0 & 6 & 1 & 7 & 6 \\
\hline Stereolepis gigas & 0 & 0 & 0 & 0 & 0 & 2 & 0 & 1 & 0 & 0 & 0 \\
\hline Torpedo californica & 1 & 0 & 0 & 0 & 0 & 0 & 0 & 0 & 0 & 0 & 0 \\
\hline
\end{tabular}




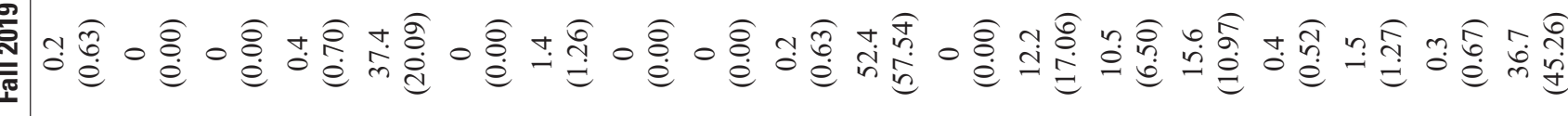

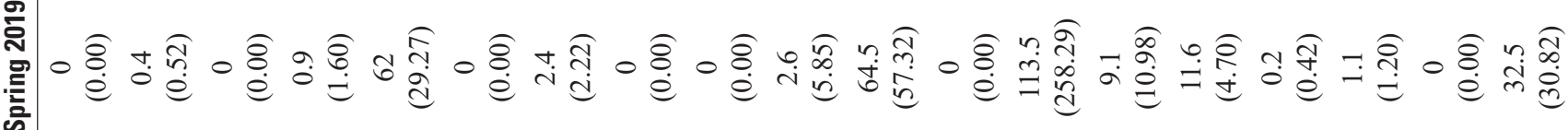

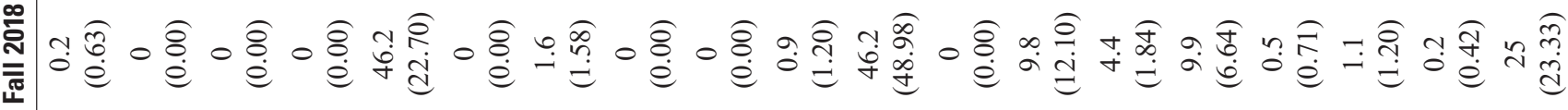

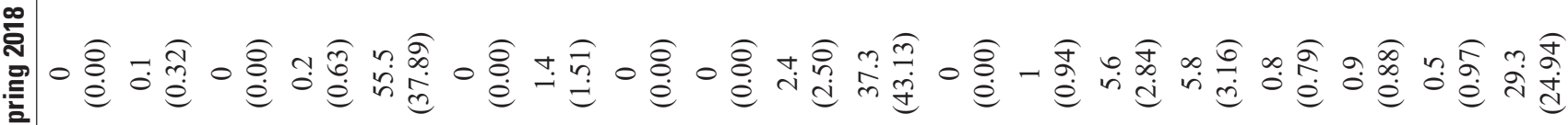

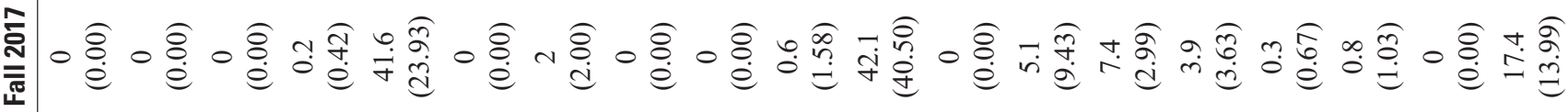

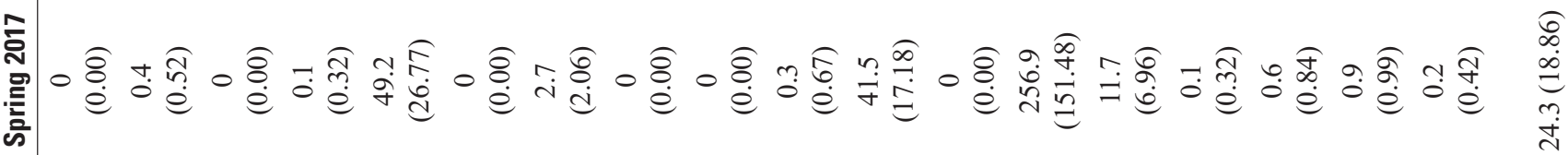

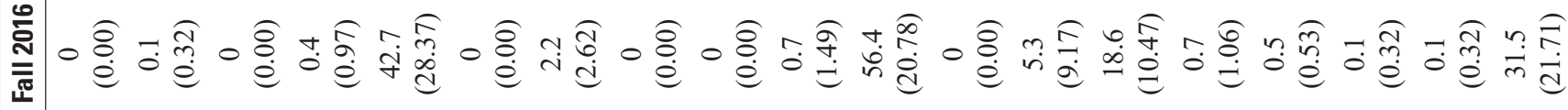

กั

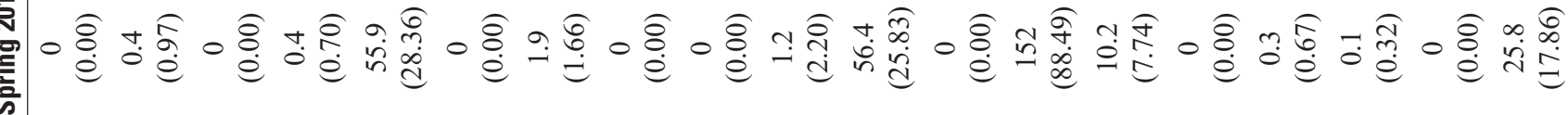

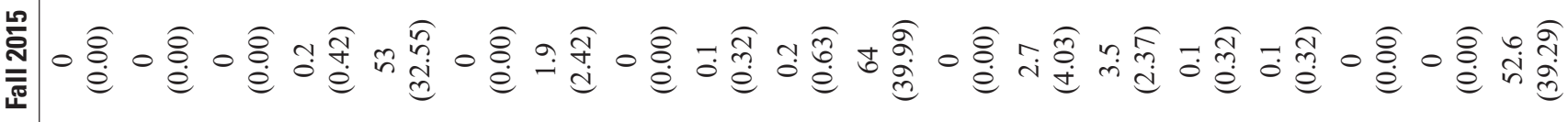

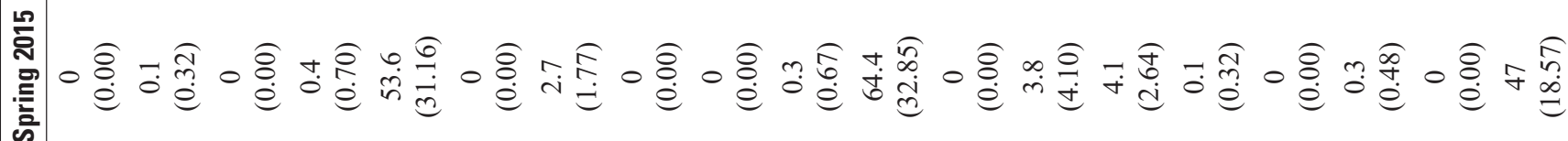

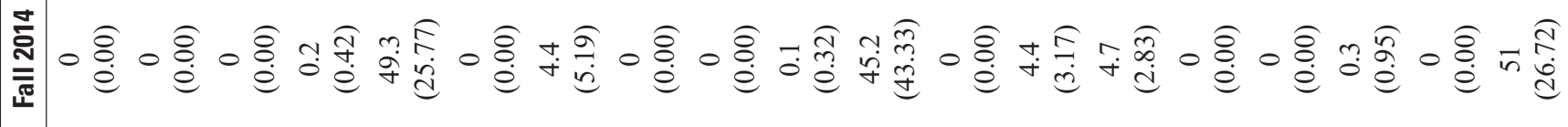




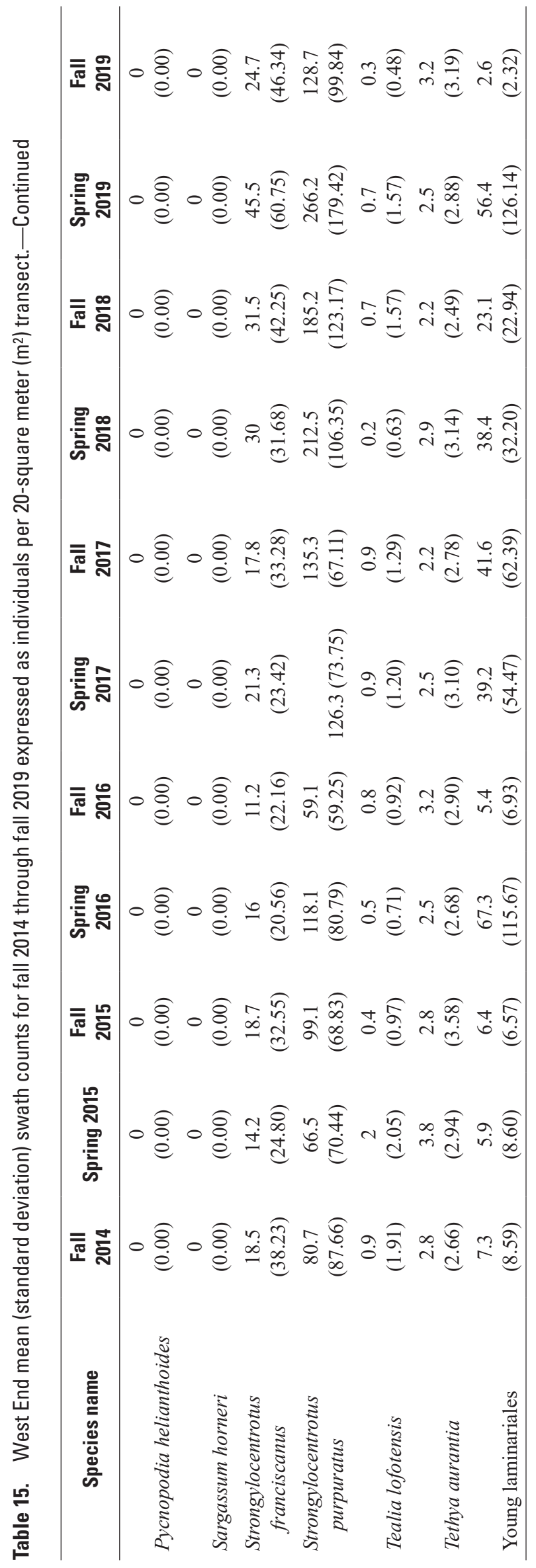


Dynamic swath counted species mean count, in 20 square meters $\left(\mathrm{m}^{2}\right)-\mathrm{W}$ est End

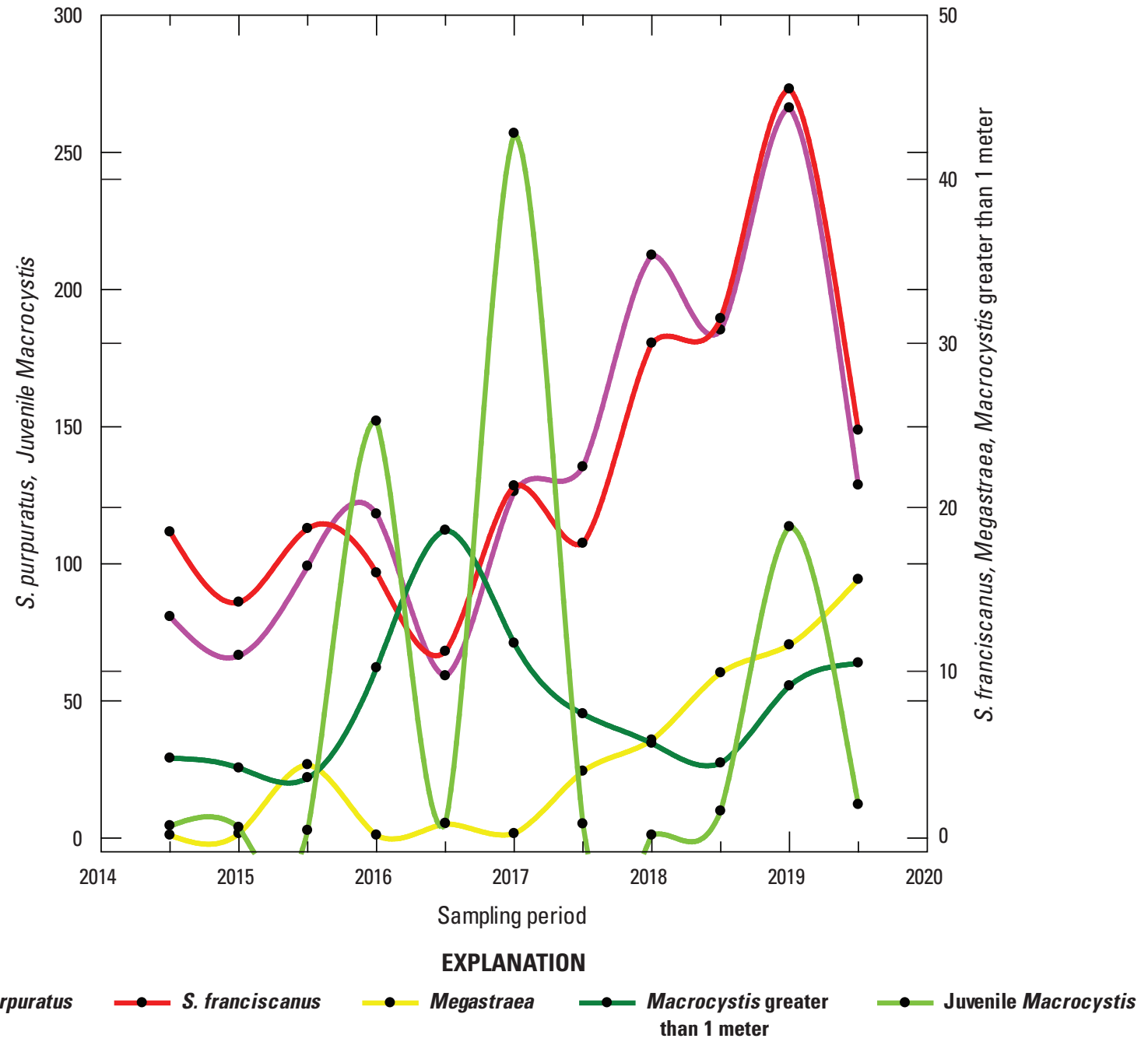

Figure 22. Mean densities of some swath-counted species that have demonstrated changing abundance at West End from fall 2014 to fall 2019 (note two vertical axes for densities of different species groups). 


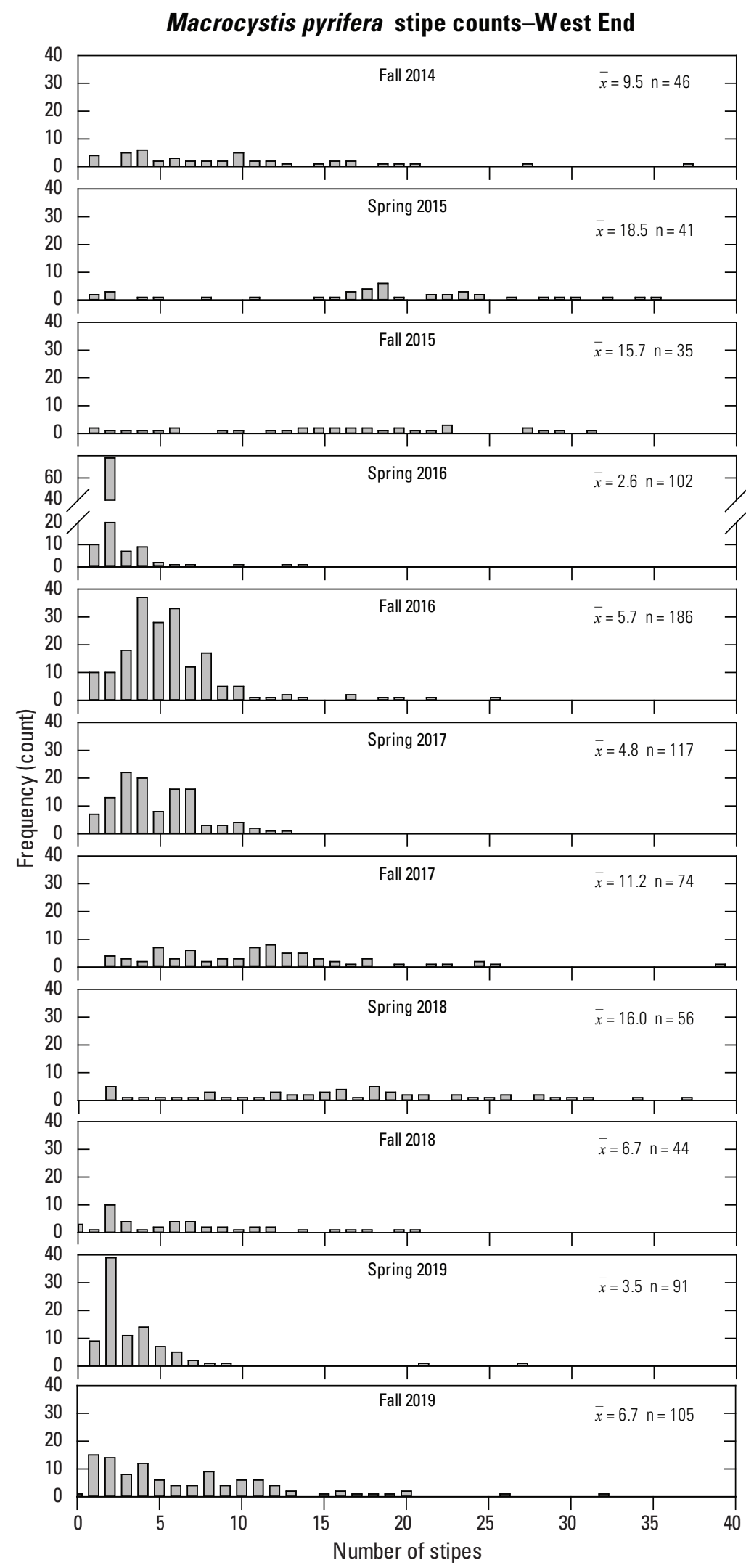

Figure 23. West End Macrocystis pyrifera (greater than $1 \mathrm{~m}$ tall) stipe counts by season: Fall 2014-fall 2019 ( $\bar{x}$ is mean count, $\mathrm{n}$ is number of individuals). 


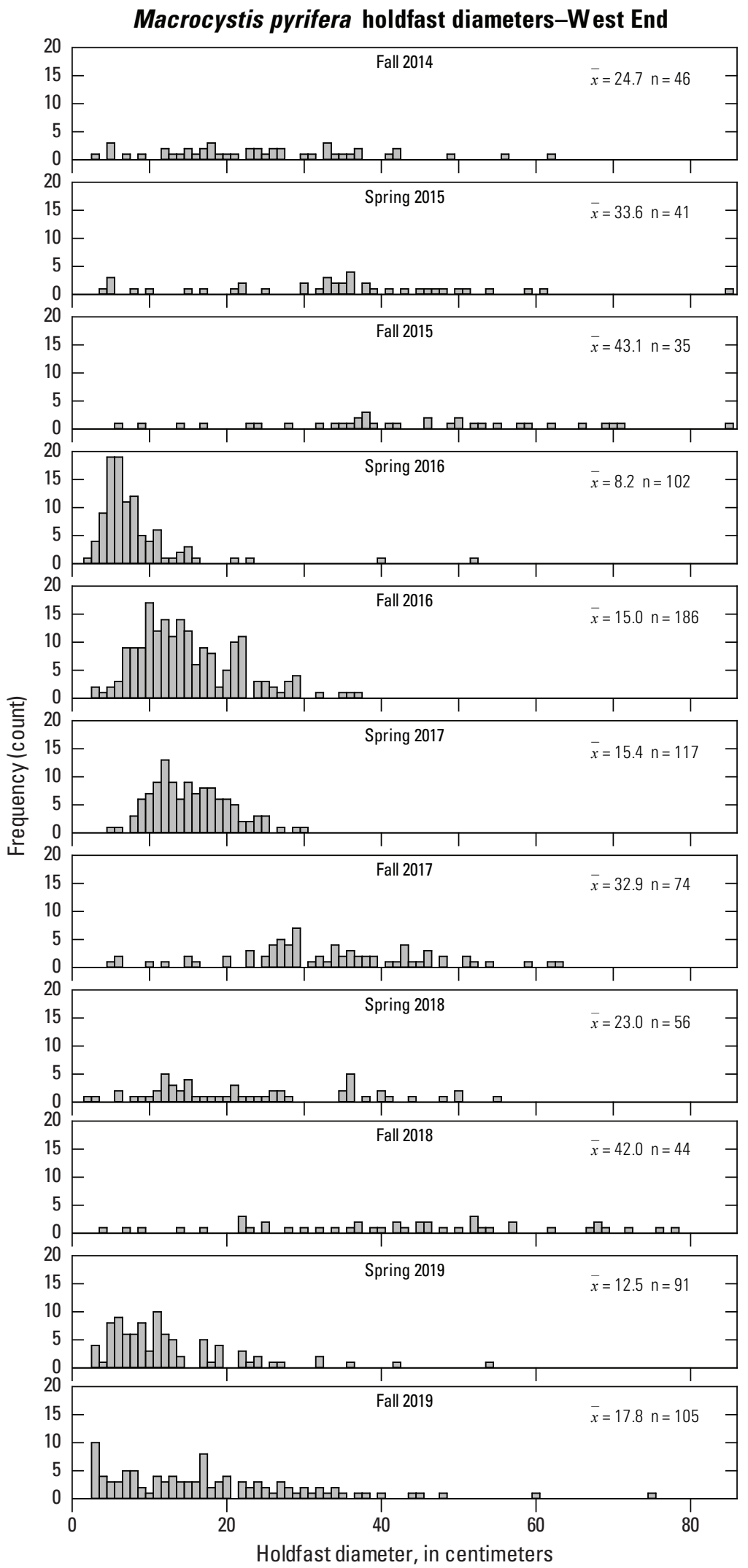

Figure 24. West End Macrocystis pyrifera (greater than $1 \mathrm{~m}$ tall) holdfast diameters by season: Fall 2014-fall 2019 ( $\bar{x}$ is mean diameter, $\mathrm{n}$ is number of individuals). 
Table 16. Sizes of invertebrates measured on swaths at West End, fall 2014 through fall 2019.

[Strongylocentrotus spp. excluded. See figures 26 and 27 for purple and red urchin size data. Abbreviations: N, sample size; Min, minimum; -, no data; Max, maximum]

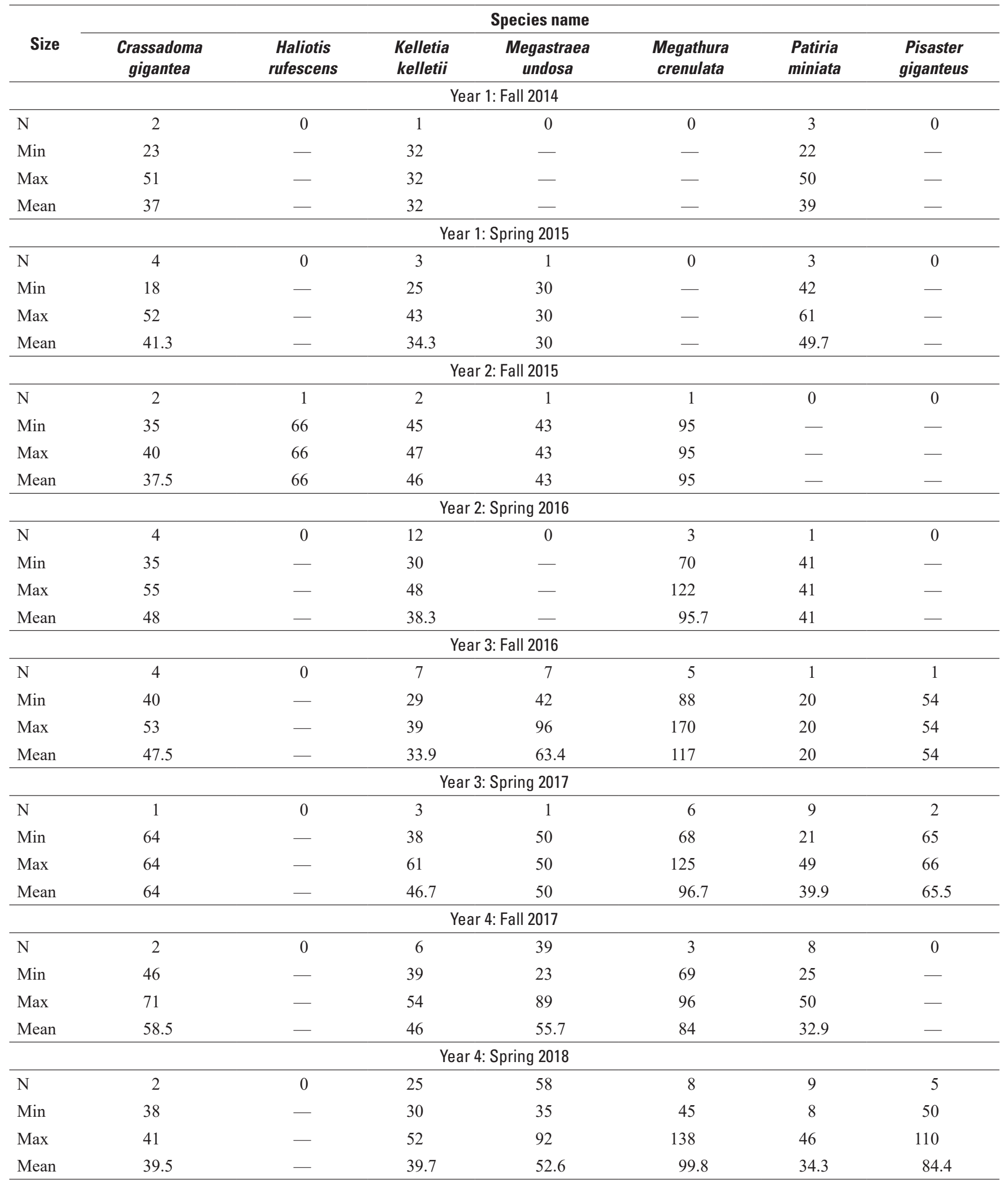


Table 16. Sizes of invertebrates measured on swaths at West End, fall 2014 through fall 2019._-Continued

[Strongylocentrotus spp. excluded. See figures 26 and 27 for purple and red urchin size data. Abbreviations: N, sample size; Min, minimum; - , no data; Max, maximum]

\begin{tabular}{|c|c|c|c|c|c|c|c|}
\hline \multirow[b]{2}{*}{ Size } & \multicolumn{7}{|c|}{ Species name } \\
\hline & $\begin{array}{c}\text { Crassadoma } \\
\text { gigantea }\end{array}$ & $\begin{array}{c}\text { Haliotis } \\
\text { rufescens }\end{array}$ & $\begin{array}{l}\text { Kelletia } \\
\text { kelletii }\end{array}$ & $\begin{array}{c}\text { Megastraea } \\
\text { undosa }\end{array}$ & $\begin{array}{l}\text { Megathura } \\
\text { crenulata }\end{array}$ & $\begin{array}{l}\text { Patiria } \\
\text { miniata }\end{array}$ & $\begin{array}{c}\text { Pisaster } \\
\text { giganteus }\end{array}$ \\
\hline \multicolumn{8}{|c|}{ Year 5: Fall 2018} \\
\hline $\mathrm{N}$ & 0 & 0 & 9 & 99 & 5 & 11 & 2 \\
\hline Min & - & - & 42 & 30 & 100 & 30 & 111 \\
\hline Max & - & - & 60 & 90 & 140 & 65 & 130 \\
\hline Mean & - & - & 51.1 & 57 & 118.4 & 49.8 & 120.5 \\
\hline \multicolumn{8}{|c|}{ Year 5: Spring 2019} \\
\hline $\mathrm{N}$ & 9 & 0 & 26 & 116 & 2 & 8 & 0 \\
\hline Min & 40 & - & 27 & 21 & 72 & 40 & - \\
\hline Max & 71 & - & 53 & 93 & 106 & 55 & - \\
\hline Mean & 50.6 & - & 39.5 & 55.2 & 89 & 49.4 & - \\
\hline \multicolumn{8}{|c|}{ Year 6: Fall 2019} \\
\hline $\mathrm{N}$ & 4 & 0 & 2 & 156 & 4 & 15 & 3 \\
\hline Min & 54 & - & 43 & 30 & 102 & 29 & 110 \\
\hline Max & 55 & - & 51 & 82 & 125 & 61 & 150 \\
\hline Mean & 54.5 & - & 47 & 61 & 110.5 & 45.7 & 123.7 \\
\hline
\end{tabular}

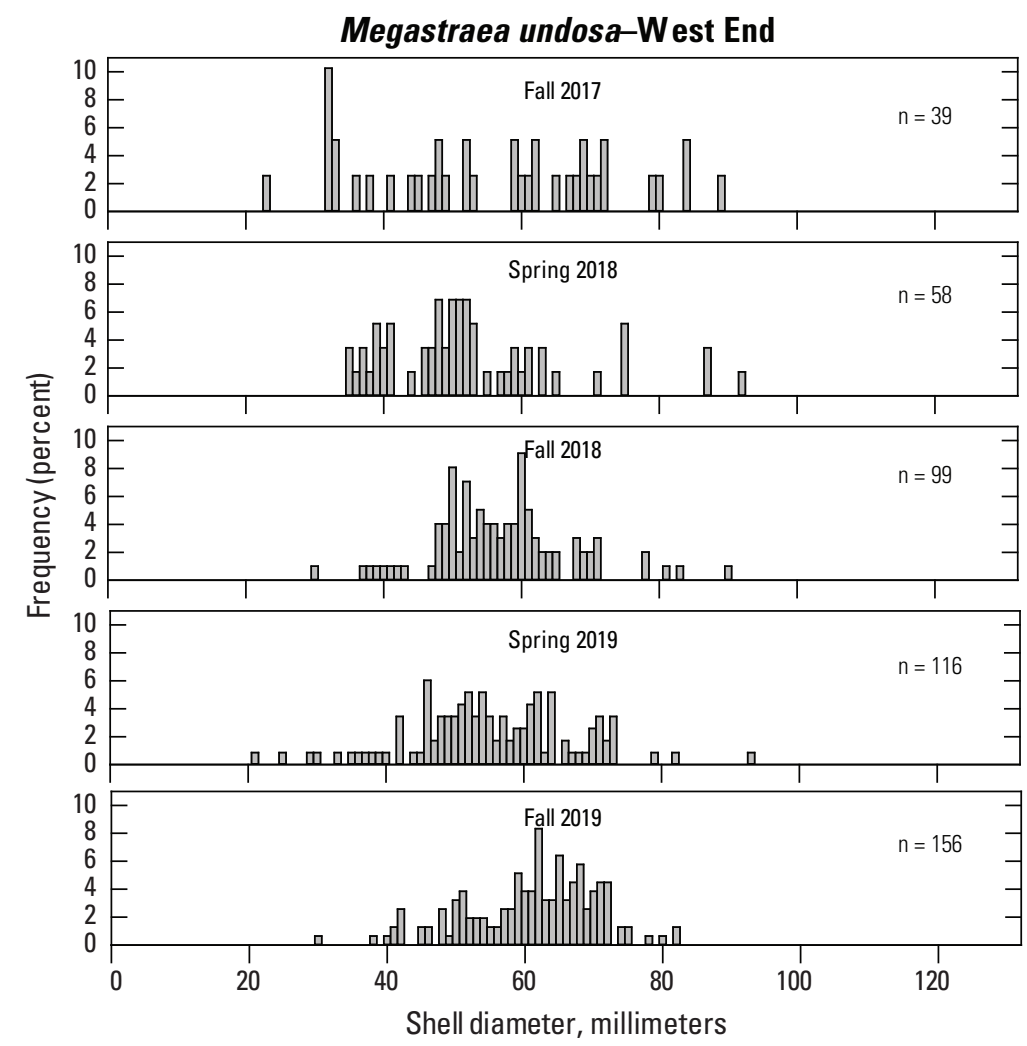

Figure 25. West End size structure of Megastraea undosa (wavy turban snails) in fall 2017-fall 2019 ( $n=$ number of individuals). 


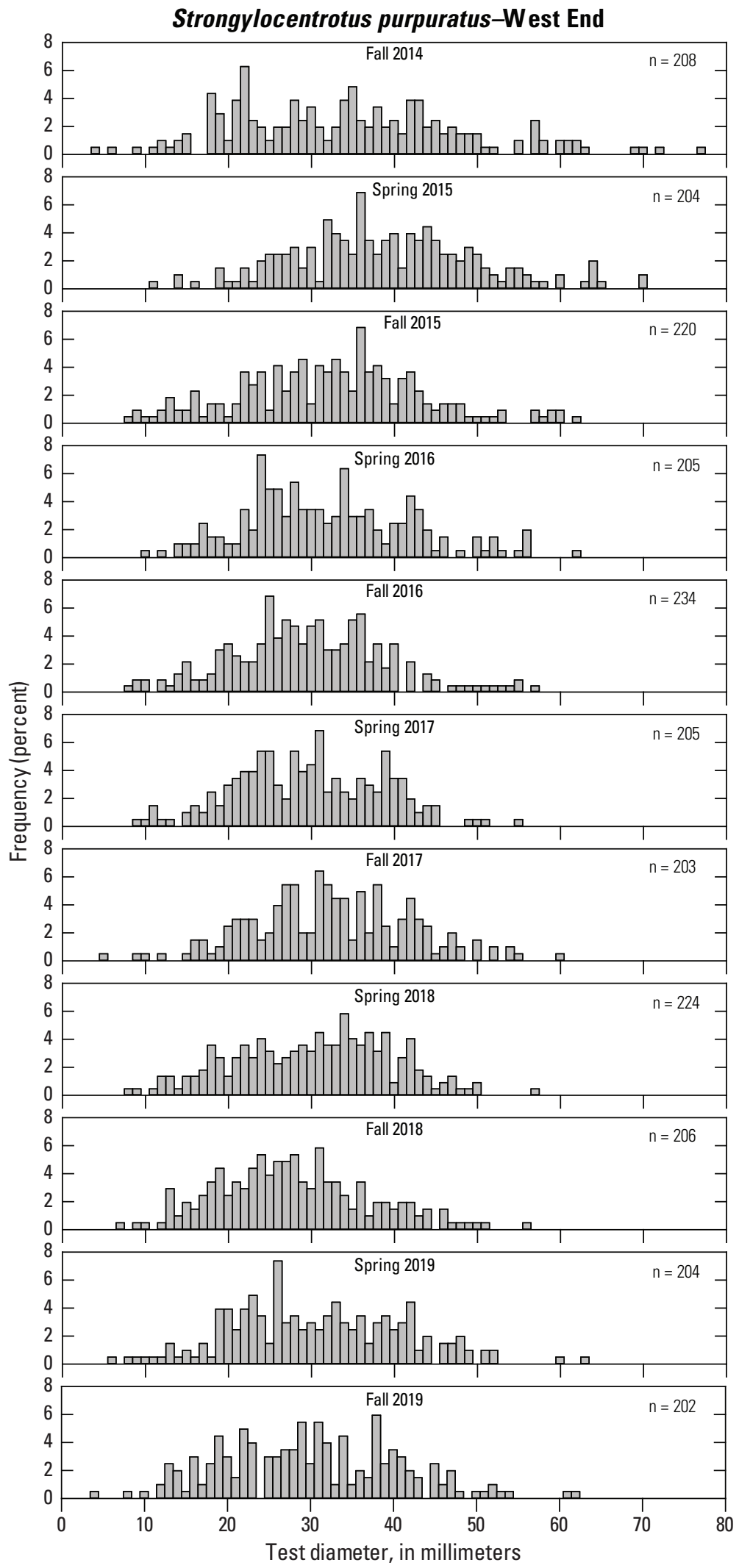

Figure 26. West End size structure of Strongylocentrotus purpuratus (purple urchins) in fall 2014-fall 2019 ( $n=$ number of individuals.). 


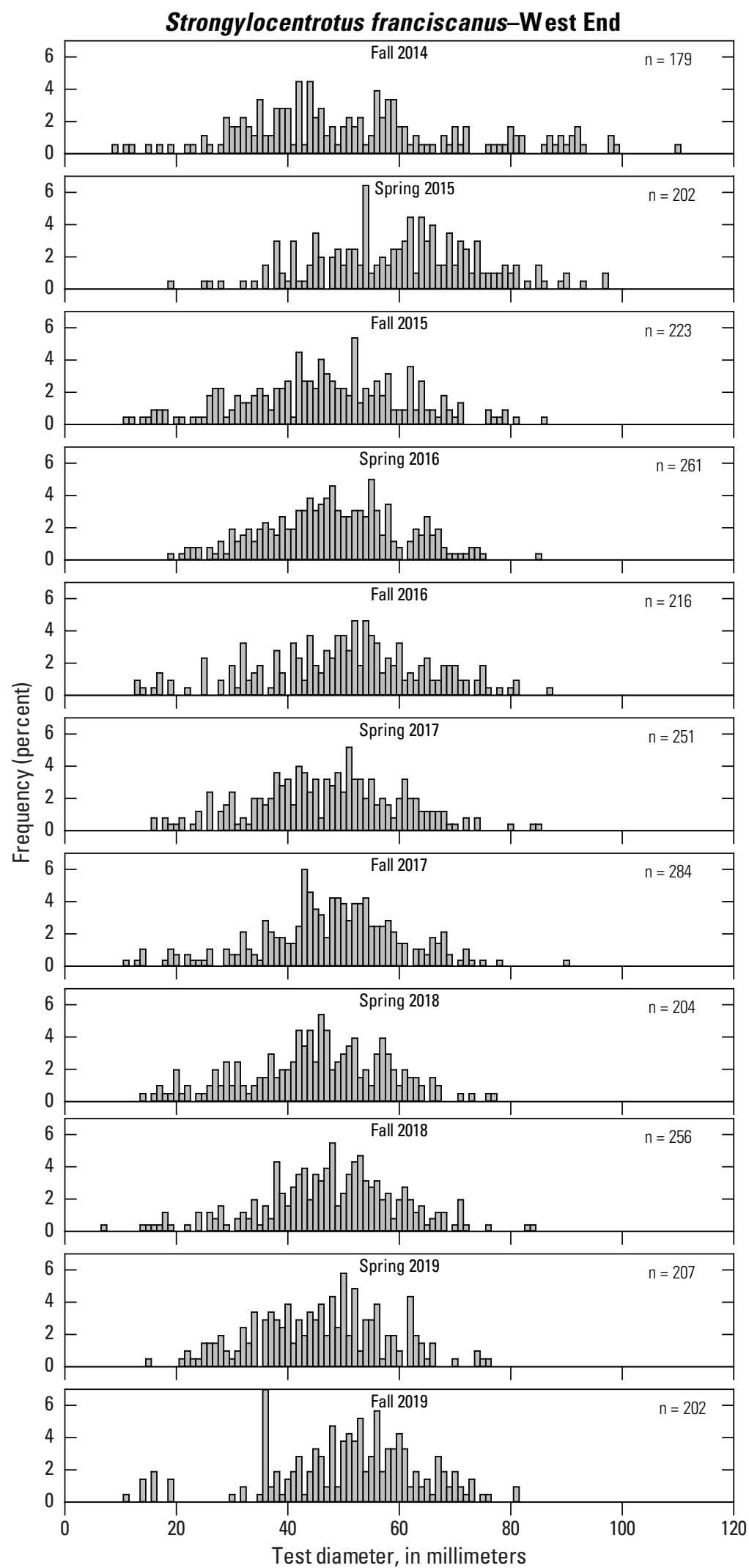

Figure 27. West End size structure of Strongylocentrotus franciscanus (red urchins) in fall 2014-fall 2019 (n=number of individuals). 
years. Sea otters, which are size selective predators and have shown a preference for $S$. franciscanus, previously concentrated their activities at the West End but have recently increased their use of other parts of the island (Yee and others, 2020).

Of the invertebrate species counted in $1-\mathrm{m}^{2}$ quadrats at West End, only $S$. montereyensis and T. aurantia were observed on all sampling trips (table 17). The gastropods, L. gibberosa, C. spadicea, K. kelletii, and N. norrisii, occurred at the site, but were not present in quadrats in more than a few sampling periods.

West End has had the most cover from fleshy red algae of any of the supersites, but that category of cover has declined there in the last 2 years and reached a low point in fall 2019, comparable to fleshy red algal cover at Dutch Harbor (fig. 21). Encrusting algae, kelp, and erect coralline algae were the categories that provided the most bottom cover at West End. Cystoseira omundacea and D. binghamiae declined recently, which reduced the brown algal cover. The species accounting for most of the remaining cover after encrusting corallines were the erect coralline Calliarthron spp. and several kelps, including Laminaria spp., P. californica, kelp holdfasts, and Macrocystis (table 18).

The number of fish species observed at West End declined slightly to 14 in fall 2019 (table 13). The total number of fish counted was higher than previous spring and fall totals but still down considerably from fall 2014 to spring
2017. The most common fish were the schooling species O. californica and C. punctipinnis, which together drive much of the temporal variability. Embiotoca jacksoni (black perch), S. pulcher, and Girella nigricans (opaleye) were among the other common species there (table 19).

\section{Dutch Harbor}

Trends in the abundance of some of the most dynamic species that were counted on the swaths at the Dutch Harbor supersite are shown in figure 28. Both S. purpuratus and S. franciscanus, which had doubled in density between 2017 and 2018, declined by approximately one third between spring and fall 2019. The C. gigantea followed a similar trend in recent years, increasing substantially in 2017 but declining by half in the same period as the urchin decline. Megastraea undosa, which, like at West End, increased from near zero in the last 2 years, changed the trajectory of its population growth in the last period to a slight decline. Following recruitment events that were detected in both 2019 surveys, "adult" M. pyrifera reached the highest density since 2016.

Strongylocentrotus purpuratus, followed by $S$. franciscanus and T. lofotensis, remained the most common three swath-counted organisms at Dutch Harbor (table 20).

Table 17. West End mean (and standard deviation) of the species counted in twenty 1-m² quadrats for fall 2014 through fall 2019.

\begin{tabular}{|c|c|c|c|c|c|c|c|c|c|c|c|}
\hline Species name & $\begin{array}{l}\text { Fall } \\
2014\end{array}$ & $\begin{array}{l}\text { Spring } \\
2015\end{array}$ & $\begin{array}{l}\text { Fall } \\
2015\end{array}$ & $\begin{array}{l}\text { Spring } \\
2016\end{array}$ & $\begin{array}{l}\text { Fall } \\
2016\end{array}$ & $\begin{array}{l}\text { Spring } \\
2017\end{array}$ & $\begin{array}{l}\text { Fall } \\
2017\end{array}$ & $\begin{array}{l}\text { Spring } \\
2018\end{array}$ & $\begin{array}{l}\text { Fall } \\
2018\end{array}$ & $\begin{array}{l}\text { Spring } \\
2019\end{array}$ & $\begin{array}{l}\text { Fall } \\
2019\end{array}$ \\
\hline $\begin{array}{l}\text { Lithopoma } \\
\quad \text { gibberosa }\end{array}$ & $\begin{array}{c}0.0 \\
(0.00)\end{array}$ & $\begin{array}{c}0.0 \\
(0.00)\end{array}$ & $\begin{array}{c}0.1 \\
(0.31)\end{array}$ & $\begin{array}{c}0.0 \\
(0.00)\end{array}$ & $\begin{array}{c}0.1 \\
(0.22)\end{array}$ & $\begin{array}{c}0.0 \\
(0.00)\end{array}$ & $\begin{array}{c}0.0 \\
(0.00)\end{array}$ & $\begin{array}{c}0.0 \\
(0.00)\end{array}$ & $\begin{array}{c}0.1 \\
(0.22)\end{array}$ & $\begin{array}{c}0.0 \\
(0.00)\end{array}$ & $\begin{array}{c}0.0 \\
(0.00)\end{array}$ \\
\hline $\begin{array}{l}\text { Cypraea } \\
\text { spadicea }\end{array}$ & $\begin{array}{c}0.1 \\
(0.22)\end{array}$ & $\begin{array}{c}0.0 \\
(0.00)\end{array}$ & $\begin{array}{c}0.0 \\
(0.00)\end{array}$ & $\begin{array}{c}0.1 \\
(0.22)\end{array}$ & $\begin{array}{c}0.0 \\
(0.00)\end{array}$ & $\begin{array}{c}0.0 \\
(0.00)\end{array}$ & $\begin{array}{c}0.0 \\
(0.00)\end{array}$ & $\begin{array}{c}0.0 \\
(0.00)\end{array}$ & $\begin{array}{c}0.0 \\
(0.00)\end{array}$ & $\begin{array}{c}0.0 \\
(0.00)\end{array}$ & $\begin{array}{c}0.0 \\
(0.00)\end{array}$ \\
\hline Kelletia kelletii & $\begin{array}{c}0.0 \\
(0.00)\end{array}$ & $\begin{array}{c}0.1 \\
(0.22)\end{array}$ & $\begin{array}{c}0.1 \\
(0.22)\end{array}$ & $\begin{array}{c}0.0 \\
(0.00)\end{array}$ & $\begin{array}{c}0.1 \\
(0.22)\end{array}$ & $\begin{array}{c}0.0 \\
(0.00)\end{array}$ & $\begin{array}{c}0.0 \\
(0.00)\end{array}$ & $\begin{array}{c}0.0 \\
(0.00)\end{array}$ & $\begin{array}{c}0.0 \\
(0.00)\end{array}$ & $\begin{array}{c}0.0 \\
(0.00)\end{array}$ & $\begin{array}{c}0.0 \\
(0.00)\end{array}$ \\
\hline Norrisia norrisi & $\begin{array}{c}0.0 \\
(0.00)\end{array}$ & $\begin{array}{c}0.1 \\
(0.22)\end{array}$ & $\begin{array}{c}0.0 \\
(0.00)\end{array}$ & $\begin{array}{c}0.0 \\
(0.00)\end{array}$ & $\begin{array}{c}0.2 \\
(0.37)\end{array}$ & $\begin{array}{c}0.1 \\
(0.31)\end{array}$ & $\begin{array}{c}0.1 \\
(0.22)\end{array}$ & $\begin{array}{c}0.1 \\
(0.22)\end{array}$ & $\begin{array}{c}0.2 \\
(0.49)\end{array}$ & $\begin{array}{c}0.1 \\
(0.31)\end{array}$ & $\begin{array}{c}0.1 \\
(0.31)\end{array}$ \\
\hline $\begin{array}{c}\text { Sargassum } \\
\text { horneri }\end{array}$ & $\begin{array}{c}0.0 \\
(0.00)\end{array}$ & $\begin{array}{c}0.0 \\
(0.00)\end{array}$ & $\begin{array}{c}0.0 \\
(0.00)\end{array}$ & $\begin{array}{c}0.0 \\
(0.00)\end{array}$ & $\begin{array}{c}0.0 \\
(0.00)\end{array}$ & $\begin{array}{c}0.0 \\
(0.00)\end{array}$ & $\begin{array}{c}0.0 \\
(0.00)\end{array}$ & $\begin{array}{c}0.0 \\
(0.00)\end{array}$ & $\begin{array}{c}0.0 \\
(0.00)\end{array}$ & $\begin{array}{c}0.0 \\
(0.00)\end{array}$ & $\begin{array}{c}0.0 \\
(0.00)\end{array}$ \\
\hline $\begin{array}{l}\text { Styela } \\
\quad \text { montereyensis }\end{array}$ & $\begin{array}{c}0.2 \\
(0.41)\end{array}$ & $\begin{array}{c}0.3 \\
(0.55)\end{array}$ & $\begin{array}{c}0.1 \\
(0.31)\end{array}$ & $\begin{array}{c}0.1 \\
(0.22)\end{array}$ & $\begin{array}{c}0.2 \\
(0.52)\end{array}$ & $\begin{array}{c}0.1 \\
(0.31)\end{array}$ & $\begin{array}{c}0.3 \\
(0.73)\end{array}$ & $\begin{array}{c}0.2 \\
(0.37)\end{array}$ & $\begin{array}{c}0.1 \\
(0.22)\end{array}$ & $\begin{array}{c}0.2 \\
(0.49)\end{array}$ & $\begin{array}{c}0.1 \\
(0.31)\end{array}$ \\
\hline Tegula regina & $\begin{array}{c}0.0 \\
(0.00)\end{array}$ & $\begin{array}{c}0.0 \\
(0.00)\end{array}$ & $\begin{array}{c}0.0 \\
(0.00)\end{array}$ & $\begin{array}{c}0.0 \\
(0.00)\end{array}$ & $\begin{array}{c}0.0 \\
(0.00)\end{array}$ & $\begin{array}{c}0.0 \\
(0.00)\end{array}$ & $\begin{array}{c}0.0 \\
(0.00)\end{array}$ & $\begin{array}{c}0.0 \\
(0.00)\end{array}$ & $\begin{array}{c}0.0 \\
(0.00)\end{array}$ & $\begin{array}{c}0.0 \\
(0.00)\end{array}$ & $\begin{array}{c}0.0 \\
(0.00)\end{array}$ \\
\hline Tethya aurantia & $\begin{array}{c}0.2 \\
(0.37)\end{array}$ & $\begin{array}{c}0.1 \\
(0.22)\end{array}$ & $\begin{array}{c}0.1 \\
(0.31)\end{array}$ & $\begin{array}{c}0.1 \\
(0.22)\end{array}$ & $\begin{array}{c}0.1 \\
(0.31)\end{array}$ & $\begin{array}{c}0.1 \\
(0.31)\end{array}$ & $\begin{array}{c}0.1 \\
(0.31)\end{array}$ & $\begin{array}{c}0.1 \\
(0.31)\end{array}$ & $\begin{array}{c}0.1 \\
(0.31)\end{array}$ & $\begin{array}{c}0.1 \\
(0.31)\end{array}$ & $\begin{array}{c}0.1 \\
(0.31)\end{array}$ \\
\hline Tealia lofotensis & $\begin{array}{c}0.0 \\
(0.00)\end{array}$ & $\begin{array}{c}0.0 \\
(0.00)\end{array}$ & $\begin{array}{c}0.0 \\
(0.00)\end{array}$ & $\begin{array}{c}0.0 \\
(0.00)\end{array}$ & $\begin{array}{c}0.0 \\
(0.00)\end{array}$ & $\begin{array}{c}0.0 \\
(0.00)\end{array}$ & $\begin{array}{c}0.0 \\
(0.00)\end{array}$ & $\begin{array}{c}0.0 \\
(0.00)\end{array}$ & $\begin{array}{c}0.0 \\
(0.00)\end{array}$ & $\begin{array}{c}0.0 \\
(0.00)\end{array}$ & $\begin{array}{c}0.0 \\
(0.00)\end{array}$ \\
\hline
\end{tabular}


Table 18. West End point contact "species" ranked by the sum of points for fall 2014 through fall 2019.

$[<$, less than; m, meter; $>$, greater than]

\begin{tabular}{|c|c|c|c|c|c|c|c|c|c|c|c|}
\hline Species name & $\begin{array}{l}\text { Fall } \\
2014\end{array}$ & $\begin{array}{c}\text { Spring } \\
2015\end{array}$ & $\begin{array}{l}\text { Fall } \\
2015\end{array}$ & $\begin{array}{c}\text { Spring } \\
2016\end{array}$ & $\begin{array}{l}\text { Fall } \\
2016\end{array}$ & $\begin{array}{c}\text { Spring } \\
2017\end{array}$ & $\begin{array}{l}\text { Fall } \\
2017\end{array}$ & $\begin{array}{c}\text { Spring } \\
2018\end{array}$ & $\begin{array}{l}\text { Fall } \\
2018\end{array}$ & $\begin{array}{c}\text { Spring } \\
2019\end{array}$ & $\begin{array}{l}\text { Fall } \\
2019\end{array}$ \\
\hline Encrusting coralline algae & 267 & 257 & 249 & 125 & 257 & 140 & 196 & 203 & 168 & 221 & 254 \\
\hline Laminaria spp. & 102 & 67 & 60 & 57 & 56 & 88 & 28 & 20 & 25 & 48 & 49 \\
\hline Rhodymenia californica & 83 & 47 & 41 & 67 & 73 & 68 & 30 & 31 & 15 & 5 & 4 \\
\hline Sand & 41 & 25 & 21 & 26 & 35 & 49 & 40 & 17 & 59 & 9 & 26 \\
\hline Dictyota binghamiae & 4 & 4 & 2 & 67 & 21 & 58 & 36 & 49 & 45 & 44 & 1 \\
\hline Encrusting red algae & 9 & 20 & 29 & 10 & 15 & 18 & 25 & 53 & 47 & 41 & 22 \\
\hline Cryptopleura spp. & 43 & 10 & 21 & 69 & 4 & 40 & 9 & 25 & 4 & 19 & 6 \\
\hline Bare substratum & 8 & 17 & 15 & 1 & 25 & 5 & 28 & 8 & 8 & 9 & 10 \\
\hline Gigartina exasperata & 32 & 24 & 13 & 17 & 17 & 14 & 8 & 3 & 1 & 1 & 3 \\
\hline Macrocystis pyrifera $>1 \mathrm{~m}$ & 12 & 3 & 6 & 8 & 16 & 15 & 20 & 11 & 10 & 4 & 24 \\
\hline Prionitis lanceolata & 7 & 16 & 9 & 13 & 11 & 6 & 16 & 4 & 13 & 8 & 12 \\
\hline Nienburgia andersoniana & 3 & 27 & 5 & 43 & 0 & 23 & 0 & 1 & 1 & 0 & 0 \\
\hline Gelidium robustum & 15 & 20 & 10 & 7 & 5 & 6 & 7 & 7 & 7 & 9 & 4 \\
\hline Phragmatopoma californica & 0 & 0 & 2 & 1 & 3 & 1 & 31 & 11 & 11 & 12 & 5 \\
\hline Bossiella spp. & 3 & 4 & 1 & 0 & 0 & 6 & 1 & 5 & 4 & 8 & 14 \\
\hline Serpulorbis squamiger & 2 & 0 & 3 & 1 & 1 & 1 & 5 & 8 & 8 & 6 & 8 \\
\hline Pterosiphonia spp. & 0 & 2 & 3 & 0 & 0 & 7 & 0 & 4 & 0 & 14 & 0 \\
\hline Corallina officinalis & 1 & 2 & 0 & 3 & 3 & 0 & 1 & 1 & 3 & 5 & 5 \\
\hline Neoptilota densa & 6 & 2 & 1 & 7 & 1 & 1 & 2 & 0 & 0 & 0 & 0 \\
\hline Plocamium pacificum & 2 & 2 & 1 & 2 & 1 & 2 & 0 & 1 & 2 & 5 & 0 \\
\hline Orange encrusting sponge & 4 & 2 & 1 & 0 & 2 & 0 & 3 & 0 & 1 & 0 & 3 \\
\hline Callophyllis flabellulata & 0 & 0 & 0 & 0 & 7 & 8 & 0 & 0 & 0 & 0 & 0 \\
\hline Kallymenia pacifica & 3 & 0 & 2 & 1 & 1 & 1 & 0 & 2 & 3 & 1 & 0 \\
\hline Unidentified sponge & 1 & 5 & 2 & 0 & 0 & 0 & 1 & 1 & 0 & 0 & 2 \\
\hline Aglaophenia spp. & 0 & 0 & 0 & 2 & 0 & 5 & 0 & 0 & 0 & 0 & 4 \\
\hline Didemnum carnulentum & 1 & 2 & 1 & 0 & 2 & 0 & 4 & 1 & 0 & 0 & 0 \\
\hline Hymenamphiastra cyanocrypta & 1 & 0 & 7 & 0 & 0 & 0 & 0 & 1 & 0 & 0 & 1 \\
\hline Anthopleura sola & 1 & 2 & 0 & 1 & 0 & 2 & 1 & 1 & 0 & 0 & 0 \\
\hline Synoicum spp. & 0 & 0 & 0 & 0 & 0 & 0 & 0 & 8 & 0 & 0 & 0 \\
\hline Barnacle & 0 & 0 & 7 & 0 & 0 & 0 & 0 & 0 & 0 & 0 & 0 \\
\hline Filamentous red algae & 3 & 2 & 0 & 0 & 0 & 0 & 1 & 0 & 1 & 0 & 0 \\
\hline
\end{tabular}


Table 18. West End point contact "species" ranked by the sum of points for fall 2014 through fall 2019._-Continued

$[<$, less than; m, meter; $>$, greater than]

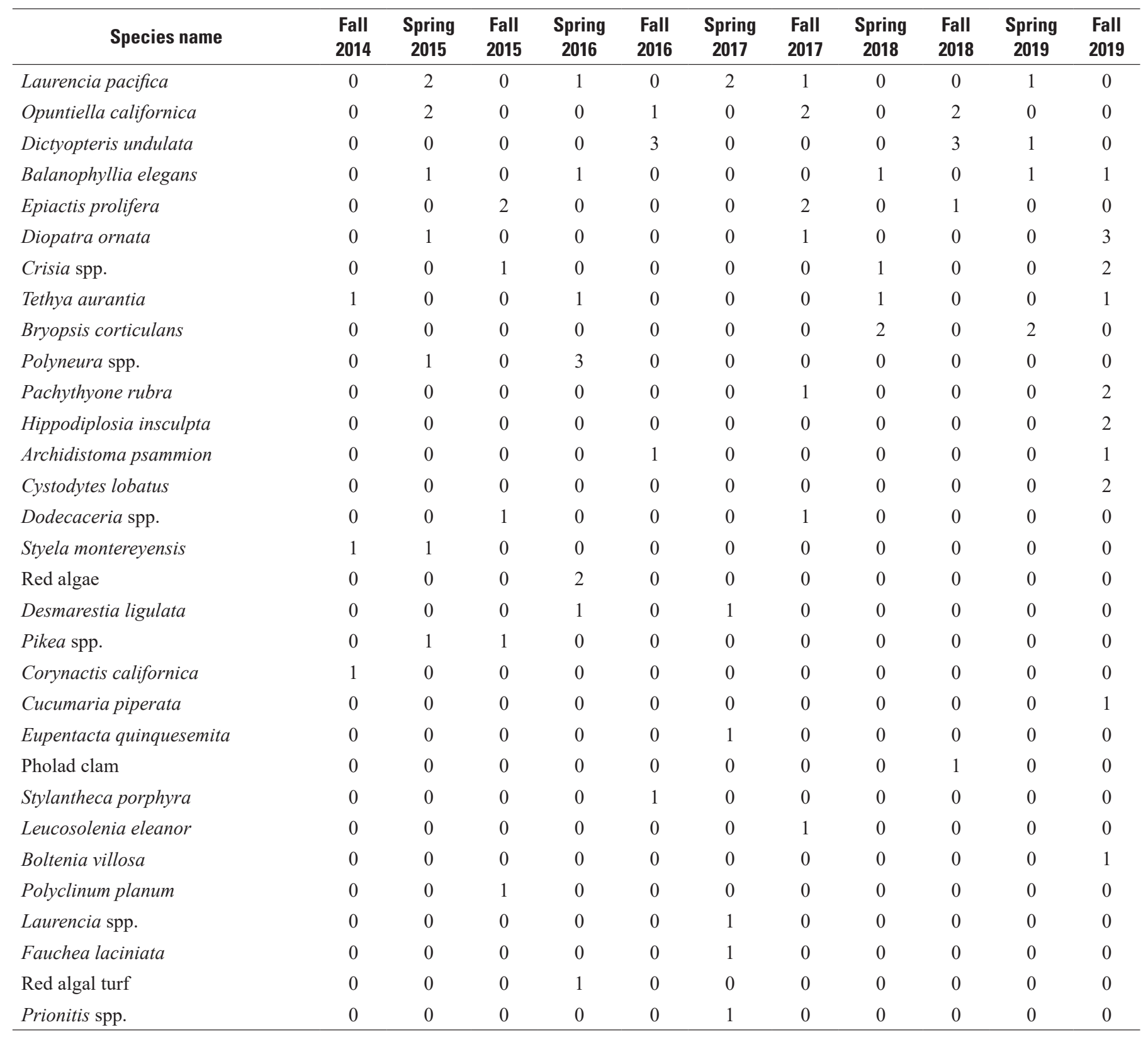




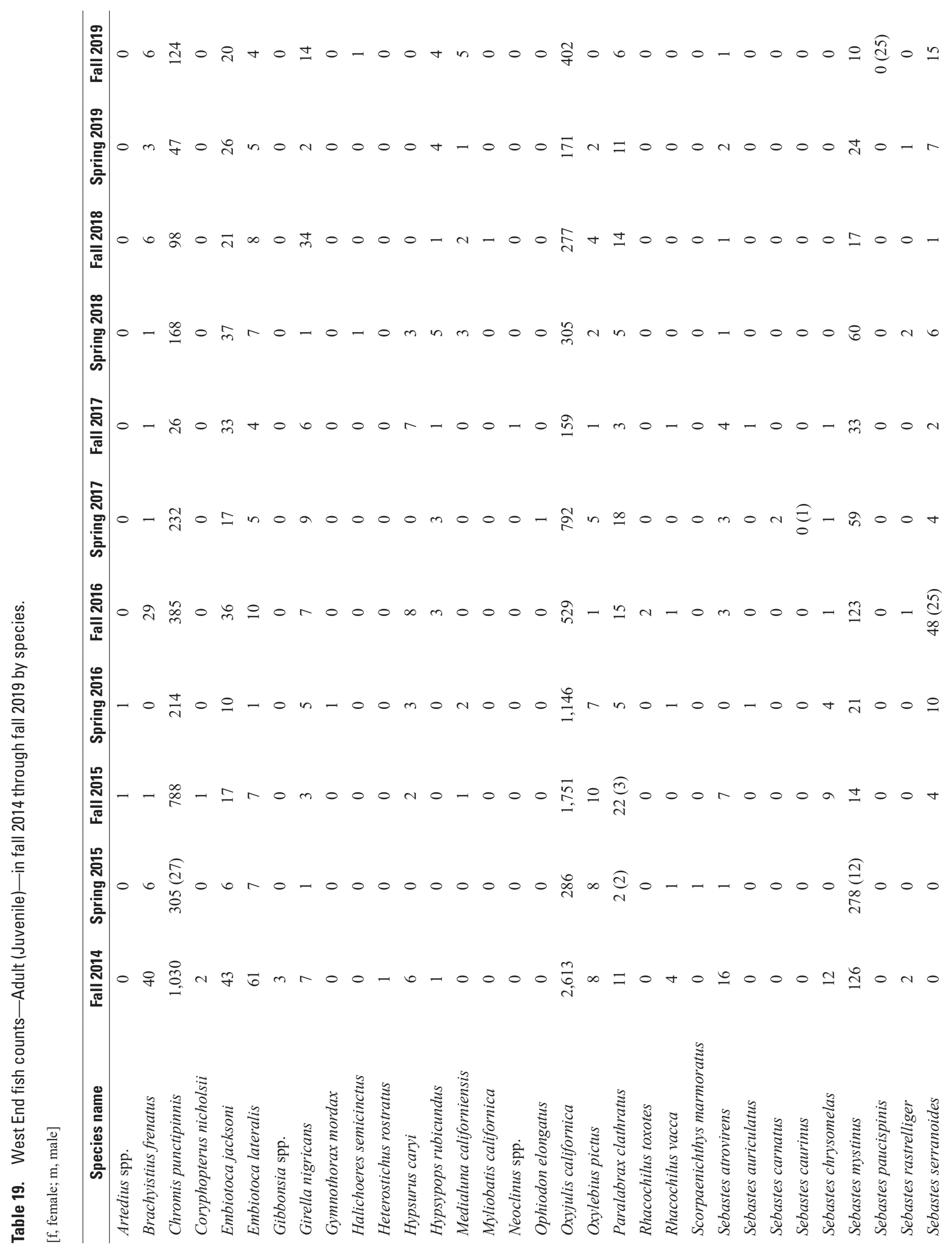




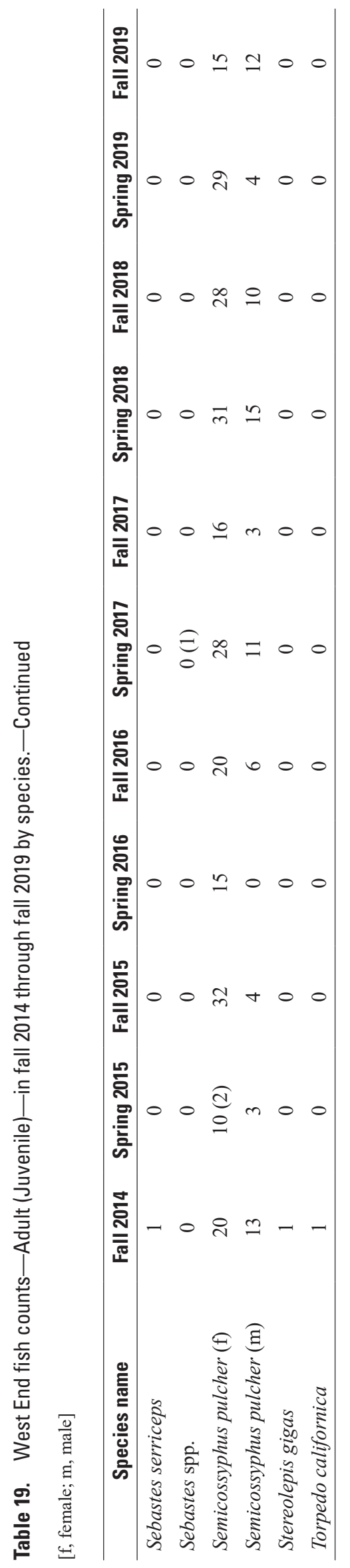




\section{Dynamic swath counted species mean count, in 20 square meters $\left(\mathrm{m}^{2}\right)$-D utch Harbor}

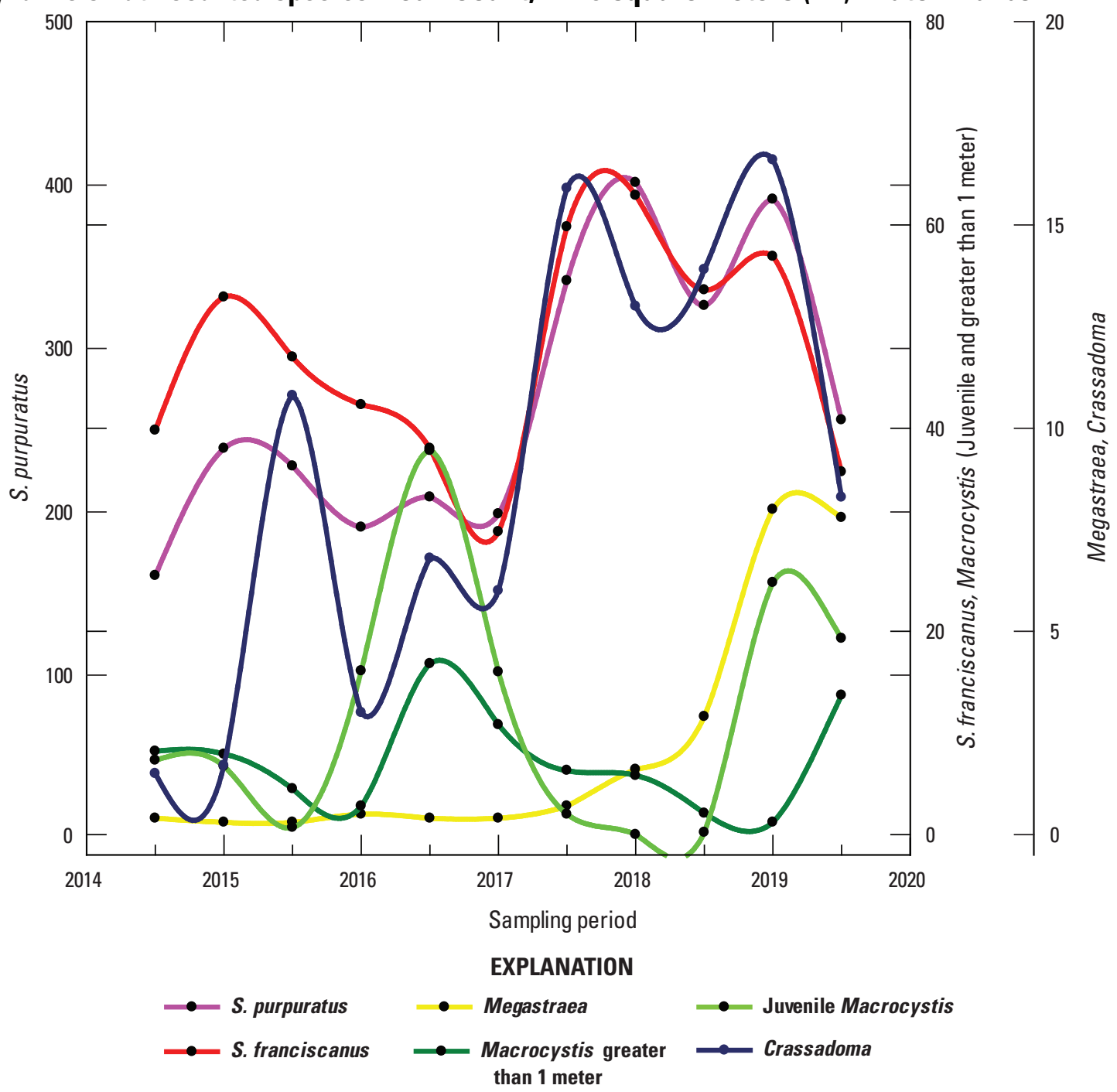

Figure 28. Mean densities of some swath-counted species that have demonstrated changing abundance at Dutch Harbor from fall 2014 to fall 2019 (note three vertical axes for densities of different species groups). 


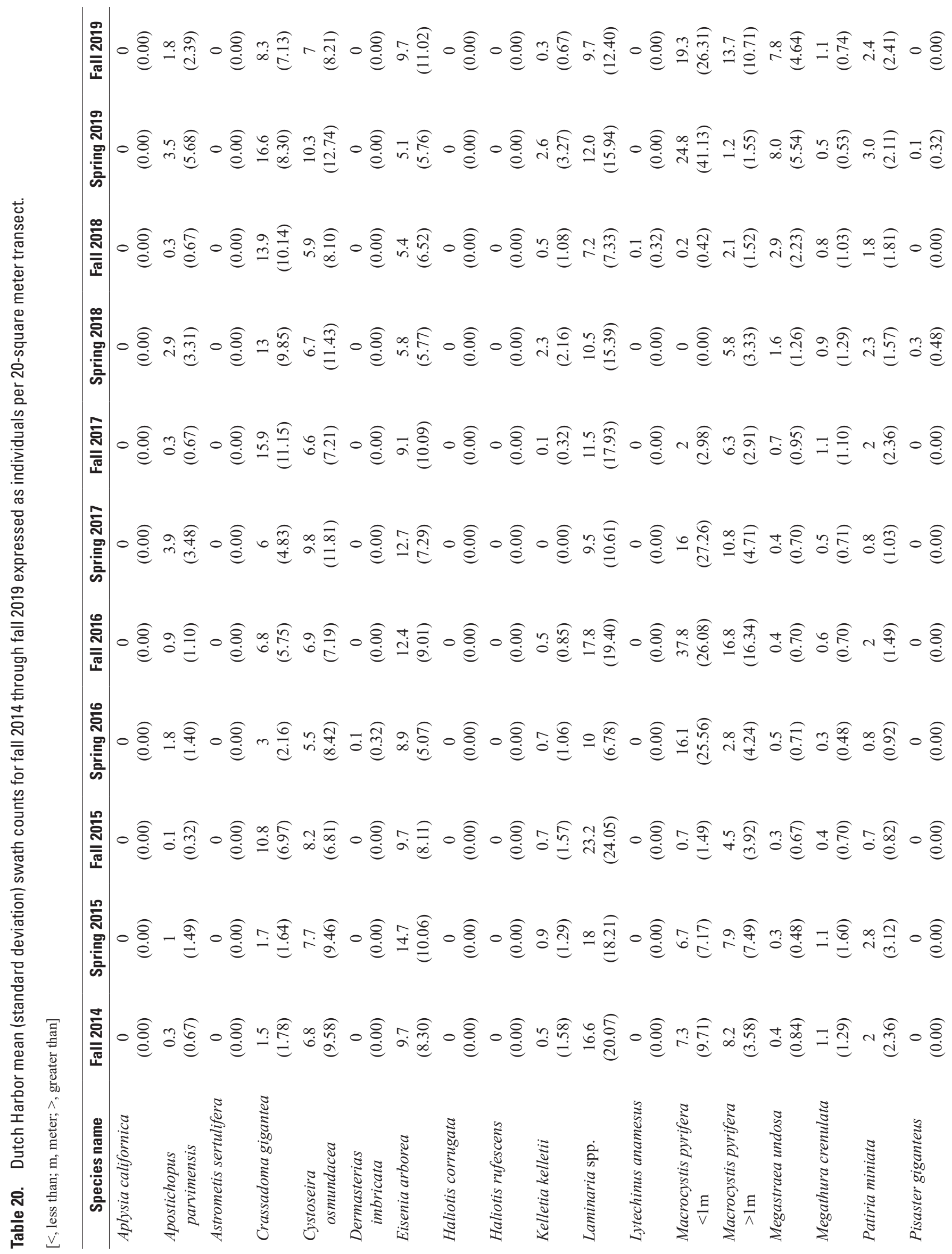




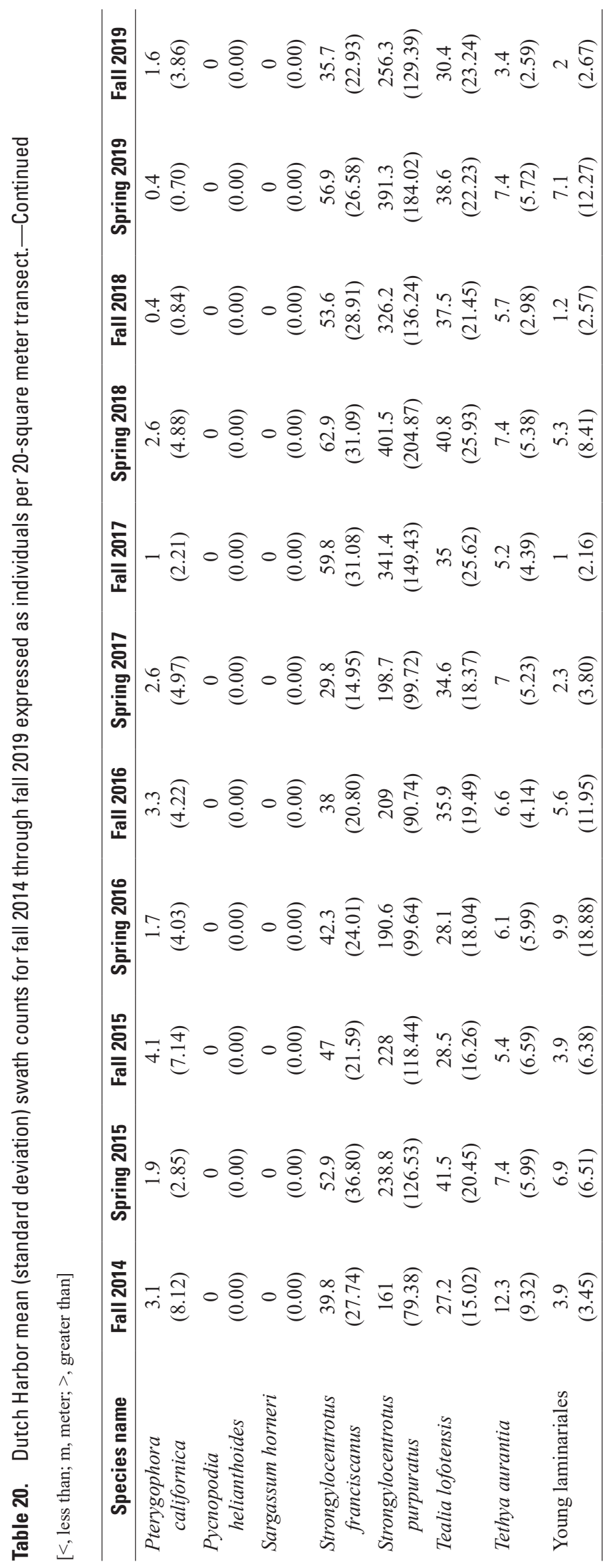


Macrocystis pyrifera was by far the most common kelp in fall 2019, with both adults and juveniles exceeding Laminaria spp. and $P$. californica, which tied for next most abundant.

Figures 29 and 30 show the stipe counts and holdfast diameters of M. pyrifera at Dutch Harbor since fall 2014. This supersite had the largest recruitment into the adult giant kelp population in 3 years. The size structure, in terms of both stipe counts and holdfast diameter, is very similar to that seen in spring 2017.

Sizes of invertebrates measured on the swaths at Dutch Harbor are summarized in table 21. Counts of the C. gigantea fell considerably in fall 2019, but neither their mean nor their maximum size changed from the previous surveys, suggesting that any decline was not due to a size-selective agent such as sea otter foraging. As mentioned previously, counts of $M$. undosa fell slightly in fall 2019, ending a trend of increase during the last several seasons. Although the mean and maximum size showed little change, there were fewer small and large individuals than in the previous sample (fig. 31). Counts of K. kelletii, Megathura crenulata (the giant keyhole limpet), and P. miniata continued to be too low or variable to draw conclusions from the size data.

The size distribution of S. purpuratus showed little change from the previous year, with almost all the samples both years ranging from 10 to $60 \mathrm{~mm}$ (fig. 32). Dutch Harbor was, again, the supersite with the most $S$. purpuratus in the largest size bin (table 9). In fall 2019, the $S$. franciscanus size distribution was strongly unimodal, centered at $54 \mathrm{~mm}$. More than 30 percent of the sample was between 50 and $56 \mathrm{~mm}$ and none exceeded $80 \mathrm{~mm}$ (fig. 33). The proportions of individuals in the three size classes strongly resembled those at West End, with most in the middle class and very few in the large class (table 10).

Tealia lofotensis remained the most common species in the $1-\mathrm{m}^{2}$ quadrat counts (table 22). Again, this season $T$. aurantia and S. montereyensis were the only other species counted in these quadrats and they remained present at low numbers.

Like in previous sampling periods, the Dutch Harbor RPC quadrats continued to be dominated by non-motile invertebrates and encrusting algae (fig. 21). This is the only supersite where invertebrates make up a large component of cover. Of the cover taxa recorded, encrusting coralline algae dominated, followed by Laminaria spp. and the tube-building polychaete, Diopatra ornata. Pink encrusting bryozoans and C. osmundacea also were common components of cover (table 23). Combined, two species of small sea cucumber, Pachythyone rubra and Cucumaria piperata, ranked higher than Laminaria spp.

Dutch Harbor continued to have the greatest number of fish species and the highest fish density of all sites (table 13). Chromis punctipinnis and O. californica accounted for most of the fish seen but Sebastes serranoides (olive rockfish), $S$. mystinus (blue rockfish), and S. pulcher were all common species there (table 24). Juvenile S. pulcher, which generally only recruit to SNI in warm-water years (Cowen, 1985), were observed in low numbers in fall 2019.

\section{Daytona 100}

Mean counts of some of the most dynamic swath-counted species measured at Daytona 100 since fall 2014 are shown in figure 34. Both urchin species fell in abundance in this period. Strongylocentrotus purpuratus, which had risen to mean densities of greater than 1,000 per $20-\mathrm{m}^{2}$ swath, fell approximately 20 percent in fall 2019, whereas $S$. franciscanus, which has exhibited a general downward trend during the last 5 years, declined by another 49 percent. The supersite still maintained kelp and urchin dominated areas. Strongylocentrotus purpuratus remained the most common swath-counted organism at Daytona. Though still the second most common swath species, $C$. osmundacea declined somewhat after it more than doubled in density during the previous 2 years. Density of the understory kelp E. arborea remained static during the last few surveys after having fallen to less than 25 percent of densities it had in 2016. Megastaea undosa declined 24 percent in fall 2019 after gradually increasing from near-zero densities over a 3-year period. Table 25 shows mean counts of these and the other swath counted species at Daytona 100 since fall 2014.

Although the density of M. pyrifera was at a 5-year low in spring 2019, a small recruitment restored densities of adult plants in fall 2019 to levels similar to those seen the previous two fall surveys. Half the sampled plants were fairly young, with only a few stipes and holdfast diameters less than $15 \mathrm{~cm}$ (figs. 35 and 36).

A summary of the sizes of non-echinoid invertebrate species observed at Daytona 100 is shown in table 26. Kelletia kelletii appear to have last recruited at this supersite in spring 2018 (fig. 37). Like at Nav Fac 100, the Daytona 100 population, in fall 2019 , seems to be in decline due to dispersion or mortality.

Megastraea undosa had a narrower size distribution at this supersite than the prior 3 years. No recruitment class is evident in the size frequency plots and only one individual exceeded 90-mm shell diameter (fig. 38). Even so, the distribution from this supersite is skewed more toward larger individuals ( 28 percent were larger than $75 \mathrm{~mm}$ ) than those from the other supersites (less than 5 percent were larger than $75 \mathrm{~mm}$ ).

Tethya aurantia, which has consistently been counted in $1 \mathrm{~m}^{2}$ quadrats at the supersite, was the only species counted in the quadrats in fall 2019 (table 27).

Strongylocentrotus purpuratus size data from Daytona 100 appears to have two modes of small urchins less than 20 $\mathrm{mm}$ in test diameter (fig. 39). This supersite and Nav Fac 100 have the highest proportion of this species in the small size classes and the lowest numbers of large urchins (table 9). The size distribution of the declining $S$. franciscanus population 


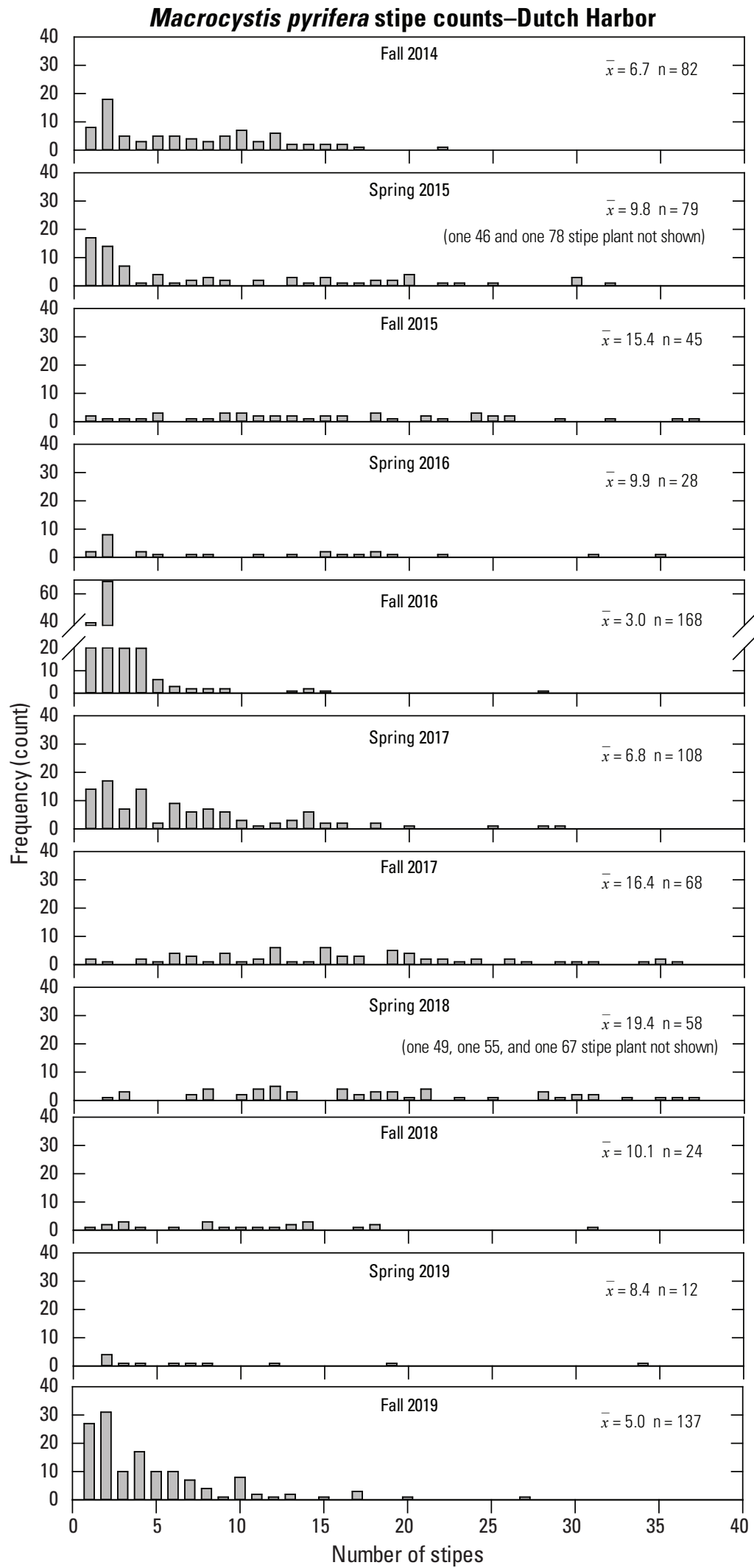

Figure 29. Dutch Harbor Macrocystis pyrifera (greater than $1 \mathrm{~m}$ tall) counts by season: Fall 2014-spring 2019 ( $\bar{x}$ is mean count, $\mathrm{n}$ is number of individuals). 


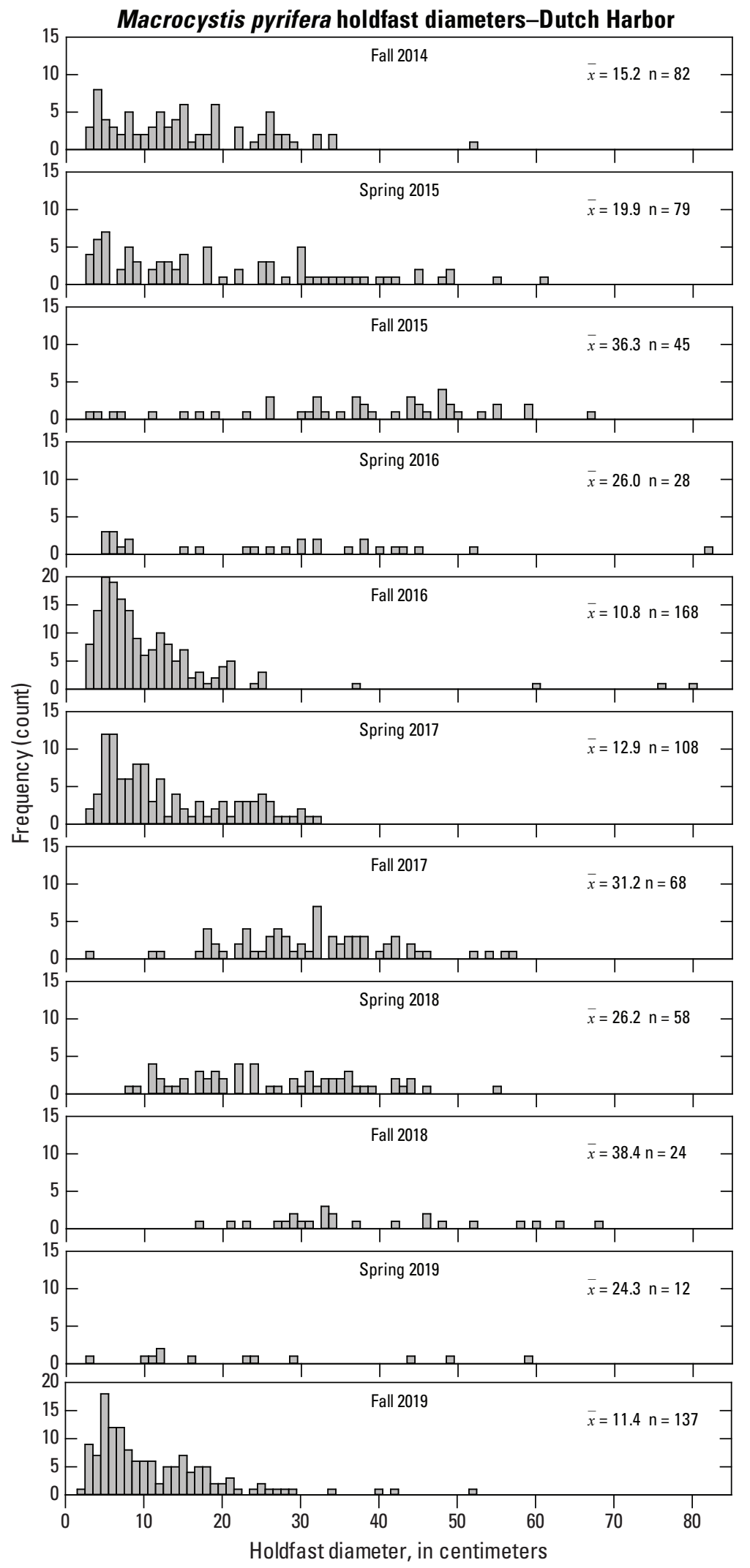

Figure 30. Dutch Harbor Macrocystis pyrifera (greater than $1 \mathrm{~m}$ tall) holdfast diameters by season: Fall 2014-fall 2019 (Note different frequency scales. $\bar{x}$ is mean diameter, $\mathrm{n}$ is number of individuals). 
Table 21. Sizes of invertebrates measured on swaths at Dutch Harbor, fall 2014 through fall 2019.

[Strongylocentrotus spp. excluded. See figures 32 and 33 for purple and red urchin size data. Abbreviations: N, sample size; Min, minimum; -, no data; Max, maximum]

\begin{tabular}{|c|c|c|c|c|c|c|c|}
\hline \multirow[b]{2}{*}{ Size } & \multicolumn{7}{|c|}{ Species name } \\
\hline & $\begin{array}{c}\text { Crassadoma } \\
\text { gigantea }\end{array}$ & $\begin{array}{c}\text { Dermasterias } \\
\text { imbricata }\end{array}$ & $\begin{array}{c}\text { Kelletia } \\
\text { kelletii }\end{array}$ & Megastraea undosa & $\begin{array}{c}\text { Megathura } \\
\text { crenulata }\end{array}$ & $\begin{array}{l}\text { Patiria } \\
\text { miniata }\end{array}$ & $\begin{array}{c}\text { Pisaster } \\
\text { giganteus }\end{array}$ \\
\hline \multicolumn{8}{|c|}{ Year 1: Fall 2014} \\
\hline $\mathrm{N}$ & 16 & 0 & 5 & 4 & 11 & 20 & 0 \\
\hline Min & 19 & - & 65 & 25 & 66 & 27 & - \\
\hline Max & 113 & - & 75 & 90 & 117 & 94 & - \\
\hline Mean & 59.2 & - & 71.4 & 63.8 & 100 & 60.3 & - \\
\hline \multicolumn{8}{|c|}{ Year 1: Spring 2015} \\
\hline $\mathrm{N}$ & 17 & 0 & 9 & 3 & 11 & 28 & 0 \\
\hline Min & 25 & - & 40 & 39 & 90 & 36 & - \\
\hline Max & 115 & - & 98 & 75 & 162 & 90 & - \\
\hline Mean & 60.9 & - & 76.3 & 52 & 124.8 & 62 & - \\
\hline \multicolumn{8}{|c|}{ Year 2: Fall 2015} \\
\hline $\mathrm{N}$ & 108 & 0 & 7 & 3 & 4 & 4 & 0 \\
\hline Min & 20 & - & 31 & 28 & 54 & 40 & - \\
\hline Max & 100 & - & 108 & 99 & 148 & 70 & - \\
\hline Mean & 58.8 & - & 55.3 & 54 & 102.2 & 56.8 & - \\
\hline \multicolumn{8}{|c|}{ Year 2: Spring 2016} \\
\hline $\mathrm{N}$ & 30 & 1 & 7 & 5 & 3 & 8 & 0 \\
\hline Min & 15 & 80 & 30 & 45 & 109 & 21 & - \\
\hline Max & 95 & 80 & 90 & 120 & 115 & 85 & - \\
\hline Mean & 67.4 & 80.5 & 56.7 & 77 & 111.3 & 55.5 & - \\
\hline \multicolumn{8}{|c|}{ Year 3: Fall 2016} \\
\hline $\mathrm{N}$ & 68 & 0 & 5 & 4 & 6 & 16 & 0 \\
\hline Min & 19 & - & 27 & 17 & 102 & 24 & - \\
\hline Max & 112 & - & 80 & 80 & 125 & 80 & - \\
\hline Mean & 61 & - & 49.8 & 49 & 116.3 & 56.4 & - \\
\hline \multicolumn{8}{|c|}{ Year 3: Spring 2017} \\
\hline $\mathrm{N}$ & 60 & 0 & 0 & 4 & 5 & 8 & 0 \\
\hline Min & 15 & - & - & 40 & 75 & 23 & - \\
\hline Max & 110 & - & - & 50 & 120 & 73 & - \\
\hline Mean & 63 & - & - & 45 & 101.4 & 56.4 & - \\
\hline \multicolumn{8}{|c|}{ Year 4: Fall 2017} \\
\hline $\mathrm{N}$ & 158 & 0 & 1 & 8 & 11 & 20 & 0 \\
\hline Min & 26 & - & 47 & 37 & 28 & 20 & - \\
\hline Max & 113 & - & 47 & 81 & 125 & 91 & - \\
\hline Mean & 65 & - & 47 & 52 & 95.8 & 61.3 & - \\
\hline \multicolumn{8}{|c|}{ Year 4: Spring 2018} \\
\hline $\mathrm{N}$ & 130 & 0 & 23 & 16 & 9 & 23 & 3 \\
\hline Min & 21 & - & 24 & 24 & 70 & 7 & 55 \\
\hline Max & 120 & - & 113 & 82 & 115 & 92 & 110 \\
\hline Mean & 59.9 & - & 51.4 & 50.3 & 91.9 & 60.1 & 77.3 \\
\hline
\end{tabular}


Table 21. Sizes of invertebrates measured on swaths at Dutch Harbor, fall 2014 through fall 2019._-Continued

[Strongylocentrotus spp. excluded. See figures 32 and 33 for purple and red urchin size data. Abbreviations: N, sample size; Min, minimum; -, no data; Max, maximum]

\begin{tabular}{|c|c|c|c|c|c|c|c|}
\hline \multirow[b]{2}{*}{ Size } & \multicolumn{7}{|c|}{ Species name } \\
\hline & $\begin{array}{c}\text { Crassadoma } \\
\text { gigantea }\end{array}$ & $\begin{array}{c}\text { Dermasterias } \\
\text { imbricata }\end{array}$ & $\begin{array}{r}\text { Kelletia } \\
\text { kelletii }\end{array}$ & Megastraea undosa & $\begin{array}{c}\text { Megathura } \\
\text { crenulata }\end{array}$ & $\begin{array}{l}\text { Patiria } \\
\text { miniata }\end{array}$ & $\begin{array}{l}\text { Pisaster } \\
\text { giganteus }\end{array}$ \\
\hline \multicolumn{8}{|c|}{ Year 5: Fall 2018} \\
\hline $\mathrm{N}$ & 188 & 0 & 5 & 46 & 9 & 18 & 0 \\
\hline Min & 24 & - & 38 & 35 & 102 & 40 & - \\
\hline \multicolumn{8}{|c|}{ Year 5: Spring 2019} \\
\hline $\mathrm{N}$ & 166 & 0 & 26 & 84 & 5 & 27 & 1 \\
\hline Min & 24 & - & 29 & 28 & 67 & 26 & 45 \\
\hline Max & 125 & - & 84 & 92 & 114 & 101 & 45 \\
\hline Min & 32 & - & 69 & 36 & 91 & 30 & - \\
\hline Max & 119 & - & 82 & 90 & 125 & 108 & - \\
\hline Mean & 73.1 & - & 73.3 & 60.6 & 107.4 & 64.2 & - \\
\hline
\end{tabular}

continues to show loss of large individuals. It has been several years since there have been more than a few small red urchins in the size sample (fig. 40). Like the trend seen at all the supersites, more than 90 percent of the sample is now made up of the middle size class (table 10).

Encrusting coralline algae continued to be the most common cover species at Daytona 100 in fall 2019. The fucalian alga, $C$. osmundacea, was the second most common following declines in the brown alga, $D$. binghamiae (table 28). The small holothurian, P. rubra, was the third most common cover species. Figure 21, which shows cover categories over time, indicates that an expansion in the cover of encrusting coralline algae came primarily as a result of a decline in cover by brown algae. The distribution of cover categories is very similar to that from 2018.

Daytona was similar in number of fish species to the previous few surveys, this time ranking just above West End and Nav Fac. Although benthic fish densities were second only to Dutch Harbor, midwater fish densities were fairly low in fall 2019, resulting in an overall density like West End and the lowest total fish count since spring 2016. As usual, most of the fish counted there were of the schooling species C. punctipinnis and O. californica, with $P$. clathratus and $S$. pulcher making up most of the remainder (table 29).

\section{Long-term Patterns}

Though $S$. purpuratus densities had recently been increasing, there was a slight decline at all the supersites in fall 2019. The mean density at Daytona 100 remained more than 1,000 S. purpuratus per swath, however, and it is unknown whether the declines observed were more than noise in a trend toward higher densities. Dutch Harbor densities of $S$. purpuratus were at record highs in spring surveys in 2018 and 2019, and the densities at West End, in spring 2019, were the highest since 2001. Strongylocentrotus franciscanus densities also declined at all supersites in fall 2019. At Daytona 100, this decline was a continuation of a trend apparent over the last several years. Figure 41 shows mean $S$. purpuratus and S. franciscanus densities since the original monitoring project was established in 1980 (appendix 1). In figure 41, and the following figures showing long-term data, Daytona 100 and Nav Fac 100 are represented only by their long-established subsites (original five $20-\mathrm{m}^{2}$ swaths), and data from the additional 50-m transects that were added in 2014 are not included.

Nav Fac first became heavily grazed following a large recruitment of $S$. purpuratus in 1991. The corresponding rapid loss of kelps can be seen in figure 42. Several abrupt, but brief, declines in $S$. purpuratus density are apparent in figure 41.

Between 2003 and 2015, the site consisted of distinct patches of algal and urchin dominated areas. There was a precipitous loss of $S$. purpuratus there in 2015, which was followed by a pulse of fleshy red algae, a moderate Macrocystis recruitment, 


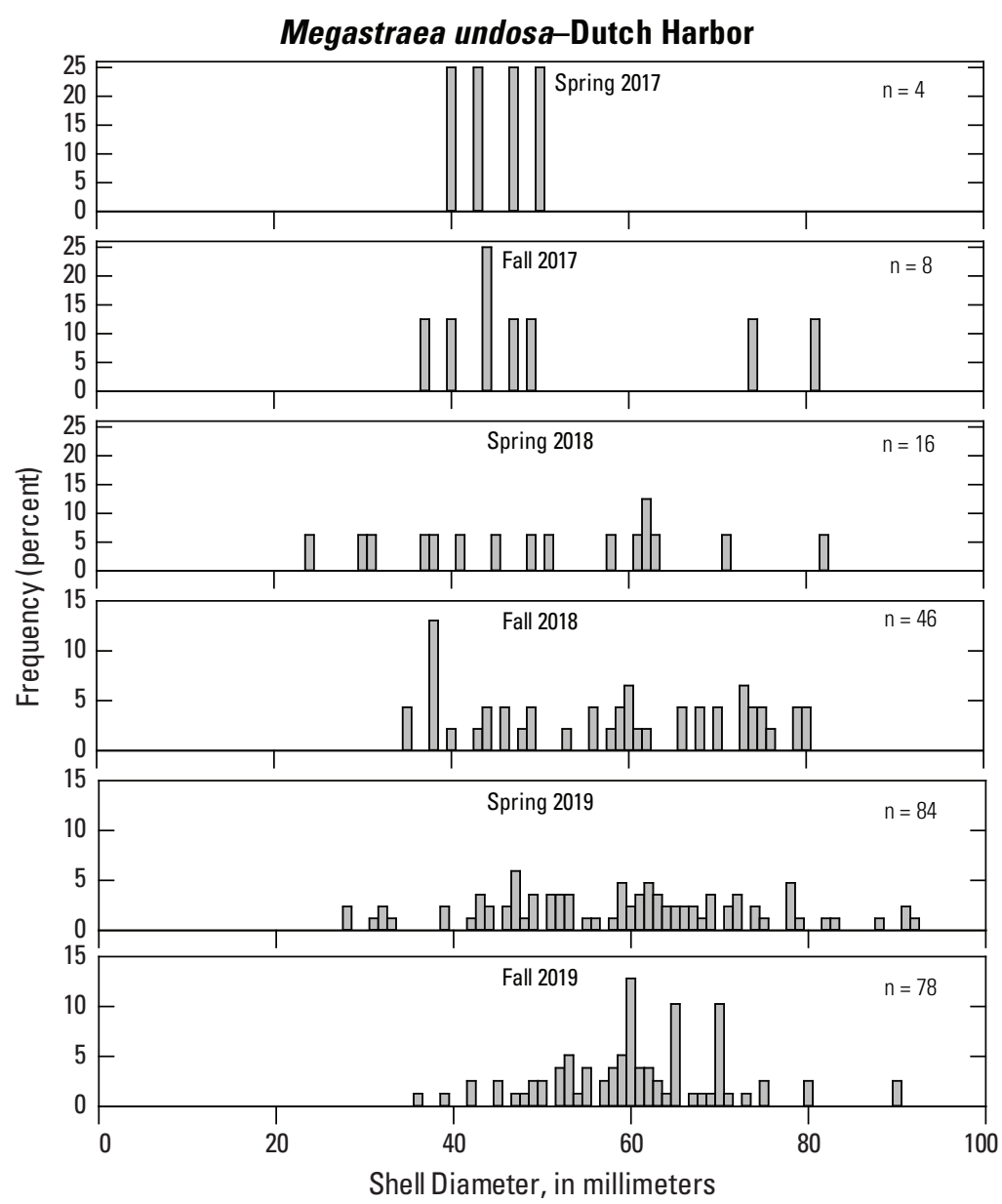

Figure 31. Dutch Harbor size distribution of Megastraea undosa (wavy turban snails) in spring 2017-fall 2019 (n=number of individuals).

and increasing density of C. osmundacea. In 2018-19, C. osmundacea, understory kelp, primarily P. californianus, and annual brown algae dominated.

Daytona 100 followed a similar trajectory in that it first became urchin dominated in 1995, and dynamic swings in urchin abundance since then (fig. 41) were met with varying response from fleshy red algae, understory kelp, and Macrocystis (fig. 43). These algae and C. osmundacea persisted but had a patchy distribution when urchin numbers rebounded. Daytona continued to be a patchwork of kelp and urchin dominated areas in 2019.

At Dutch Harbor, recruitment pulses of M. pyrifera followed by attrition, senescence, and new recruitment occurred in cyclic patterns of 2- to 3-year durations for two and a half decades. These recruitments appear as repeating peaks and troughs in figure 44. After 2007, however, there was an interruption to this pattern. Higher counts of understory kelp and higher cover of fleshy red algae occurred during this time. In 2016, the first large M. pyrifera recruitment in several years was observed in the fall, following the El Niño storms of the previous winter. This disturbance seems to have reinitiated the cycle.

Following the loss of urchins at West End in 2001 (fig. 41), M. pyrifera and understory kelps recruited heavily, and at this site, giant kelp demonstrated a pattern of recruitment and attrition similar to, though more extreme than, that seen at Dutch Harbor. The magnitude of successive recruitments at West End, however, waned as understory kelp numbers and fleshy red algal benthic cover increased (fig. 45). This site is the most exposed to swell and perhaps, because these lower growing forms are better able to survive winter storms, they may have been able to outcompete $M$. pyrifera there. After 2009, West End M. pyrifera densities remained low until 2016, when M. pyrifera underwent a modest recruitment like Dutch Harbor. Although considerably smaller than previous recruitment pulses at this site, it was the largest in several years and corresponded with a decline in red algal cover. 


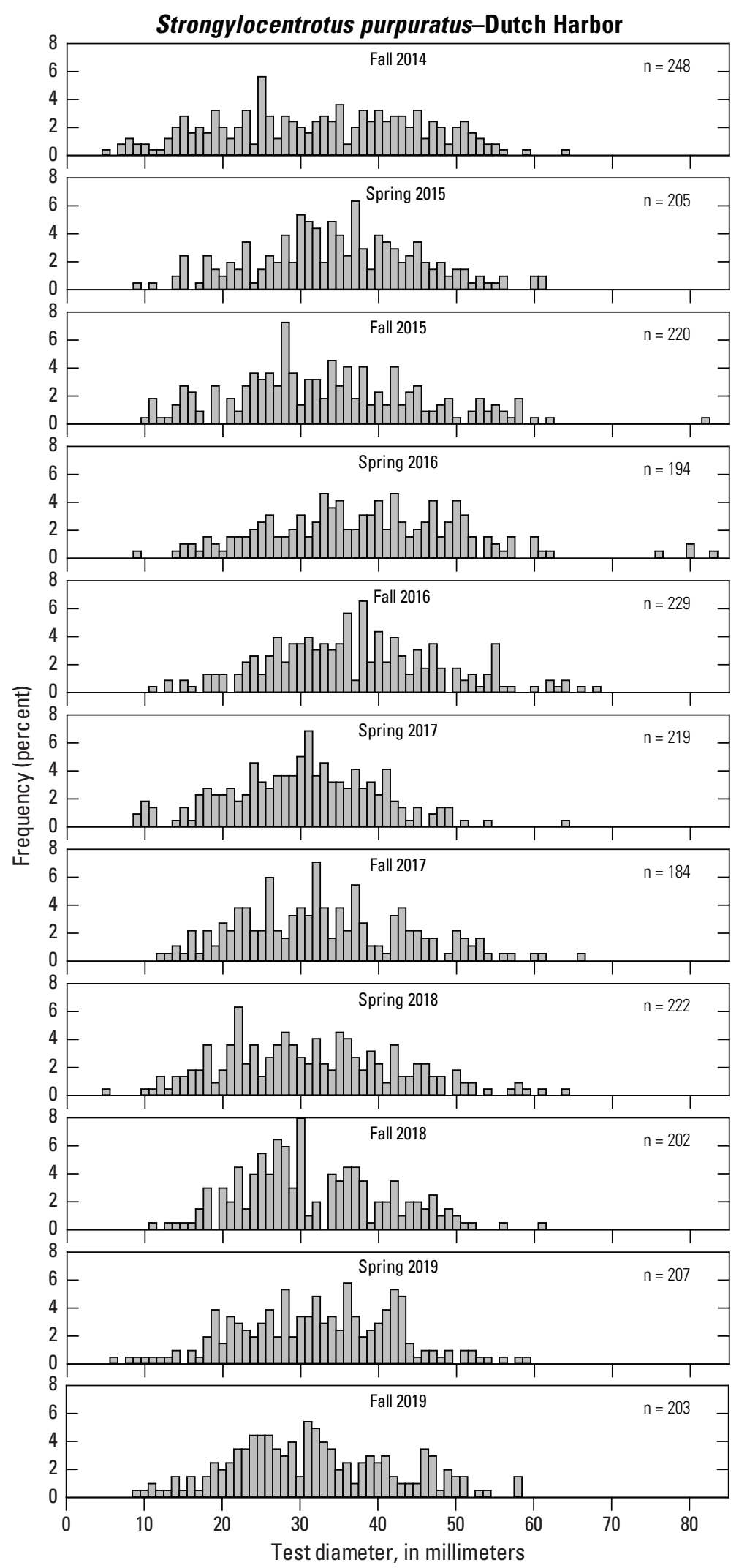

Figure 32. Dutch Harbor size structure of Strongylocentrotus purpuratus (purple urchins) fall 2014-fall 2019 (n=number of individuals). 


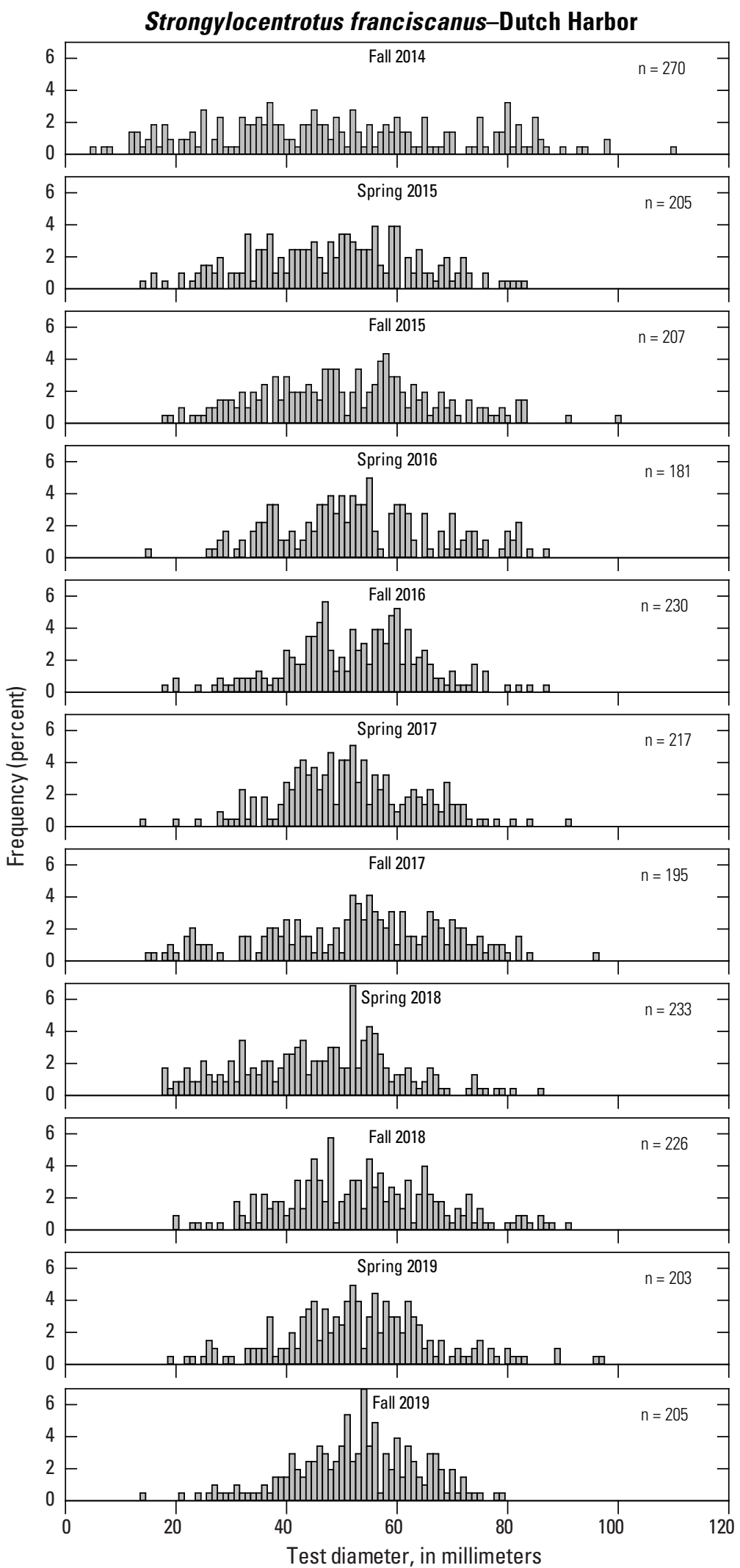

Figure 33. Dutch Harbor size structure of Strongylocentrotus franciscanus (red urchins) in fall 2014-fall 2019 ( $n=$ number of individuals). 
64 Kelp Forest Monitoring at Naval Base Ventura County, San Nicolas Island, California

Table 22. Dutch Harbor mean (and standard deviation) of the species counted in twenty 1-m² quadrats for fall 2014 through fall 2019.

\begin{tabular}{|c|c|c|c|c|c|c|c|c|c|c|c|}
\hline Species name & $\begin{array}{l}\text { Fall } \\
2014\end{array}$ & $\begin{array}{c}\text { Spring } \\
2015\end{array}$ & $\begin{array}{l}\text { Fall } \\
2015\end{array}$ & $\begin{array}{c}\text { Spring } \\
2016\end{array}$ & $\begin{array}{c}\text { Fall } \\
2016\end{array}$ & $\begin{array}{c}\text { Spring } \\
2017\end{array}$ & $\begin{array}{c}\text { Fall } \\
2017\end{array}$ & $\begin{array}{c}\text { Spring } \\
2018\end{array}$ & $\begin{array}{l}\text { Fall } \\
2018\end{array}$ & $\begin{array}{c}\text { Spring } \\
2019\end{array}$ & $\begin{array}{l}\text { Fall } \\
2019\end{array}$ \\
\hline Lithopoma gibberosa & $\begin{array}{c}0.1 \\
(0.22)\end{array}$ & $\begin{array}{c}0.0 \\
(0.00)\end{array}$ & $\begin{array}{c}0.0 \\
(0.00)\end{array}$ & $\begin{array}{c}0.0 \\
(0.00)\end{array}$ & $\begin{array}{c}0.0 \\
(0.00)\end{array}$ & $\begin{array}{c}0.1 \\
(0.22)\end{array}$ & $\begin{array}{c}0.0 \\
(0.00)\end{array}$ & $\begin{array}{c}0.0 \\
(0.00)\end{array}$ & $\begin{array}{c}0.0 \\
(0.00)\end{array}$ & $\begin{array}{c}0.0 \\
(0.00)\end{array}$ & $\begin{array}{c}0.0 \\
(0.00)\end{array}$ \\
\hline Cypraea spadicea & $\begin{array}{c}0.0 \\
(0.00)\end{array}$ & $\begin{array}{c}0.1 \\
(0.45)\end{array}$ & $\begin{array}{c}0.1 \\
(0.22)\end{array}$ & $\begin{array}{c}0.1 \\
(0.31)\end{array}$ & $\begin{array}{c}0.0 \\
(0.00)\end{array}$ & $\begin{array}{c}0.0 \\
(0.00)\end{array}$ & $\begin{array}{c}0.0 \\
(0.00)\end{array}$ & $\begin{array}{c}0.1 \\
(0.22)\end{array}$ & $\begin{array}{c}0.0 \\
(0.00)\end{array}$ & $\begin{array}{c}0.0 \\
(0.00)\end{array}$ & $\begin{array}{c}0.0 \\
(0.00)\end{array}$ \\
\hline Kelletia kelletii & $\begin{array}{c}0.0 \\
(0.00)\end{array}$ & $\begin{array}{c}0.1 \\
(0.45)\end{array}$ & $\begin{array}{c}0.0 \\
(0.00)\end{array}$ & $\begin{array}{c}0.0 \\
(0.00)\end{array}$ & $\begin{array}{c}0.0 \\
(0.00)\end{array}$ & $\begin{array}{c}0.0 \\
(0.00)\end{array}$ & $\begin{array}{c}0.0 \\
(0.00)\end{array}$ & $\begin{array}{c}0.0 \\
(0.00)\end{array}$ & $\begin{array}{c}0.0 \\
(0.00)\end{array}$ & $\begin{array}{c}0.1 \\
(0.22)\end{array}$ & $\begin{array}{c}0.0 \\
(0.00)\end{array}$ \\
\hline Norrisia norrisi & $\begin{array}{c}0.1 \\
(0.45)\end{array}$ & $\begin{array}{c}0.0 \\
(0.00)\end{array}$ & $\begin{array}{c}0.0 \\
(0.00)\end{array}$ & $\begin{array}{c}0.0 \\
(0.00)\end{array}$ & $\begin{array}{c}0.1 \\
(0.22)\end{array}$ & $\begin{array}{c}0.1 \\
(0.22)\end{array}$ & $\begin{array}{c}0.0 \\
(0.00)\end{array}$ & $\begin{array}{c}0.0 \\
(0.00)\end{array}$ & $\begin{array}{c}0.0 \\
(0.00)\end{array}$ & $\begin{array}{c}0.0 \\
(0.00)\end{array}$ & $\begin{array}{c}0.0 \\
(0.00)\end{array}$ \\
\hline Sargassum horneri & $\begin{array}{c}0.0 \\
(0.00)\end{array}$ & $\begin{array}{c}0.0 \\
(0.00)\end{array}$ & $\begin{array}{c}0.0 \\
(0.00)\end{array}$ & $\begin{array}{c}0.0 \\
(0.00)\end{array}$ & $\begin{array}{c}0.0 \\
(0.00)\end{array}$ & $\begin{array}{c}0.0 \\
(0.00)\end{array}$ & $\begin{array}{c}0.0 \\
(0.00)\end{array}$ & $\begin{array}{c}0.0 \\
(0.00)\end{array}$ & $\begin{array}{c}0.0 \\
(0.00)\end{array}$ & $\begin{array}{c}0.0 \\
(0.00)\end{array}$ & $\begin{array}{c}0.0 \\
(0.00)\end{array}$ \\
\hline Styela montereyensis & $\begin{array}{c}0.1 \\
(0.31)\end{array}$ & $\begin{array}{c}0.0 \\
(0.00)\end{array}$ & $\begin{array}{c}0.0 \\
(0.00)\end{array}$ & $\begin{array}{c}0.1 \\
(0.45)\end{array}$ & $\begin{array}{c}0.2 \\
(0.67)\end{array}$ & $\begin{array}{c}0.2 \\
(0.49)\end{array}$ & $\begin{array}{c}0.2 \\
(0.49)\end{array}$ & $\begin{array}{c}0.1 \\
(0.31)\end{array}$ & $\begin{array}{c}0.1 \\
(0.31)\end{array}$ & $\begin{array}{c}0.1 \\
(0.31)\end{array}$ & $\begin{array}{c}0.1 \\
(0.22)\end{array}$ \\
\hline Tethya aurantia & $\begin{array}{c}0.3 \\
(0.57)\end{array}$ & $\begin{array}{c}0.4 \\
(0.68)\end{array}$ & $\begin{array}{c}0.1 \\
(0.31)\end{array}$ & $\begin{array}{c}0.2 \\
(0.41)\end{array}$ & $\begin{array}{c}0.1 \\
(0.22)\end{array}$ & $\begin{array}{c}0.2 \\
(0.37)\end{array}$ & $\begin{array}{c}0.1 \\
(0.31)\end{array}$ & $\begin{array}{c}0.2 \\
(0.41)\end{array}$ & $\begin{array}{c}0.3 \\
(0.44)\end{array}$ & $\begin{array}{c}0.2 \\
(0.37)\end{array}$ & $\begin{array}{c}0.1 \\
(0.31)\end{array}$ \\
\hline Tealia lofotensis & $\begin{array}{c}0.4 \\
(0.75)\end{array}$ & $\begin{array}{c}0.6 \\
(0.89)\end{array}$ & $\begin{array}{c}0.7 \\
(1.03)\end{array}$ & $\begin{array}{c}0.6 \\
(0.94)\end{array}$ & $\begin{array}{c}0.6 \\
(1.05)\end{array}$ & $\begin{array}{c}0.7 \\
(0.93)\end{array}$ & $\begin{array}{c}0.8 \\
(0.85)\end{array}$ & $\begin{array}{c}0.5 \\
(0.76)\end{array}$ & $\begin{array}{c}0.3 \\
(0.55)\end{array}$ & $\begin{array}{c}0.6 \\
(0.89)\end{array}$ & $\begin{array}{c}0.8 \\
(1.16)\end{array}$ \\
\hline
\end{tabular}


Table 23. Dutch Harbor point contact "species" ranked by the sum of points for fall 2014 through fall 2019.

$[>$, greater than; $\mathrm{m}$, meter; $<$, less than]

\begin{tabular}{|c|c|c|c|c|c|c|c|c|c|c|c|}
\hline Species name & $\begin{array}{l}\text { Fall } \\
2014\end{array}$ & $\begin{array}{c}\text { Spring } \\
2015\end{array}$ & $\begin{array}{l}\text { Fall } \\
2015\end{array}$ & $\begin{array}{c}\text { Spring } \\
2016\end{array}$ & $\begin{array}{l}\text { Fall } \\
2016\end{array}$ & $\begin{array}{c}\text { Spring } \\
2017\end{array}$ & $\begin{array}{l}\text { Fall } \\
2017\end{array}$ & $\begin{array}{c}\text { Spring } \\
2018\end{array}$ & $\begin{array}{l}\text { Fall } \\
2018\end{array}$ & $\begin{array}{c}\text { Spring } \\
2019\end{array}$ & $\begin{array}{l}\text { Fall } \\
2019\end{array}$ \\
\hline Encrusting coralline algae & 182 & 129 & 187 & 128 & 151 & 122 & 167 & 139 & 137 & 167 & 148 \\
\hline Laminaria spp. & 45 & 57 & 46 & 47 & 43 & 40 & 58 & 50 & 43 & 38 & 53 \\
\hline Cystoseira osmundacea & 38 & 27 & 38 & 27 & 33 & 43 & 56 & 45 & 32 & 55 & 43 \\
\hline Pachythyone rubra & 13 & 29 & 25 & 19 & 35 & 44 & 69 & 36 & 28 & 11 & 35 \\
\hline Cucumaria piperata & 24 & 39 & 23 & 17 & 19 & 30 & 31 & 22 & 33 & 31 & 20 \\
\hline Rhodymenia californica & 64 & 42 & 14 & 24 & 29 & 44 & 19 & 5 & 9 & 16 & 15 \\
\hline Calliarthron spp. & 27 & 34 & 18 & 19 & 18 & 16 & 15 & 9 & 9 & 12 & 19 \\
\hline Eisenia arborea & 16 & 15 & 9 & 14 & 23 & 19 & 17 & 4 & 10 & 10 & 8 \\
\hline Aglaophenia spp. & 6 & 1 & 6 & 3 & 14 & 16 & 16 & 10 & 24 & 5 & 32 \\
\hline Encrusting red algae & 8 & 11 & 14 & 9 & 8 & 11 & 13 & 9 & 13 & 11 & 14 \\
\hline Crisia spp. & 6 & 11 & 5 & 16 & 3 & 13 & 15 & 18 & 5 & 11 & 14 \\
\hline Dictyota binghamiae & 5 & 24 & 0 & 14 & 21 & 14 & 0 & 1 & 8 & 19 & 7 \\
\hline Kelp holdfast & 5 & 2 & 18 & 21 & 13 & 10 & 8 & 6 & 8 & 3 & 0 \\
\hline Corynactis californica & 12 & 9 & 7 & 6 & 13 & 9 & 7 & 4 & 1 & 4 & 2 \\
\hline Cellaria spp. & 0 & 5 & 10 & 5 & 7 & 0 & 13 & 12 & 7 & 3 & 12 \\
\hline Astrangia lajollaensis & 4 & 8 & 3 & 5 & 7 & 6 & 6 & 9 & 10 & 8 & 6 \\
\hline Pterygophora californica & 8 & 15 & 8 & 3 & 4 & 4 & 2 & 0 & 2 & 0 & 0 \\
\hline Acarnus erithacus & 9 & 3 & 3 & 4 & 2 & 3 & 3 & 4 & 6 & 2 & 3 \\
\hline Hippodiplosia insculpta & 1 & 1 & 1 & 5 & 0 & 4 & 9 & 3 & 4 & 0 & 7 \\
\hline Nienburgia andersoniana & 1 & 4 & 1 & 2 & 4 & 9 & 1 & 4 & 0 & 3 & 1 \\
\hline Diatom film & 0 & 0 & 0 & 0 & 0 & 0 & 0 & 0 & 0 & 28 & 0 \\
\hline Serpulorbis squamiger & 2 & 2 & 2 & 1 & 0 & 4 & 2 & 5 & 4 & 2 & 2 \\
\hline Bossiella spp. & 3 & 8 & 3 & 1 & 3 & 0 & 3 & 0 & 1 & 3 & 1 \\
\hline Eupentacta quinquesemita & 0 & 5 & 0 & 0 & 5 & 2 & 2 & 0 & 3 & 6 & 1 \\
\hline Abietinaria spp. & 0 & 1 & 2 & 0 & 3 & 5 & 3 & 2 & 3 & 2 & 2 \\
\hline Lagenocella spp. & 1 & 1 & 2 & 6 & 4 & 0 & 3 & 2 & 3 & 0 & 1 \\
\hline Orange encrusting sponge & 0 & 4 & 1 & 2 & 6 & 1 & 4 & 3 & 1 & 0 & 0 \\
\hline Bugula spp. & 2 & 3 & 3 & 4 & 1 & 0 & 2 & 0 & 1 & 1 & 5 \\
\hline Hymenamphiastra cyanocrypta & 1 & 2 & 0 & 0 & 0 & 1 & 2 & 6 & 6 & 0 & 3 \\
\hline Urticina/Tealia spp. & 3 & 1 & 0 & 7 & 2 & 2 & 0 & 0 & 1 & 0 & 3 \\
\hline Anthopleura sola & 2 & 4 & 0 & 3 & 4 & 2 & 0 & 1 & 0 & 2 & 0 \\
\hline
\end{tabular}


Table 23. Dutch Harbor point contact "species" ranked by the sum of points for fall 2014 through fall 2019._Continued

$[>$, greater than; m, meter; $<$, less than]

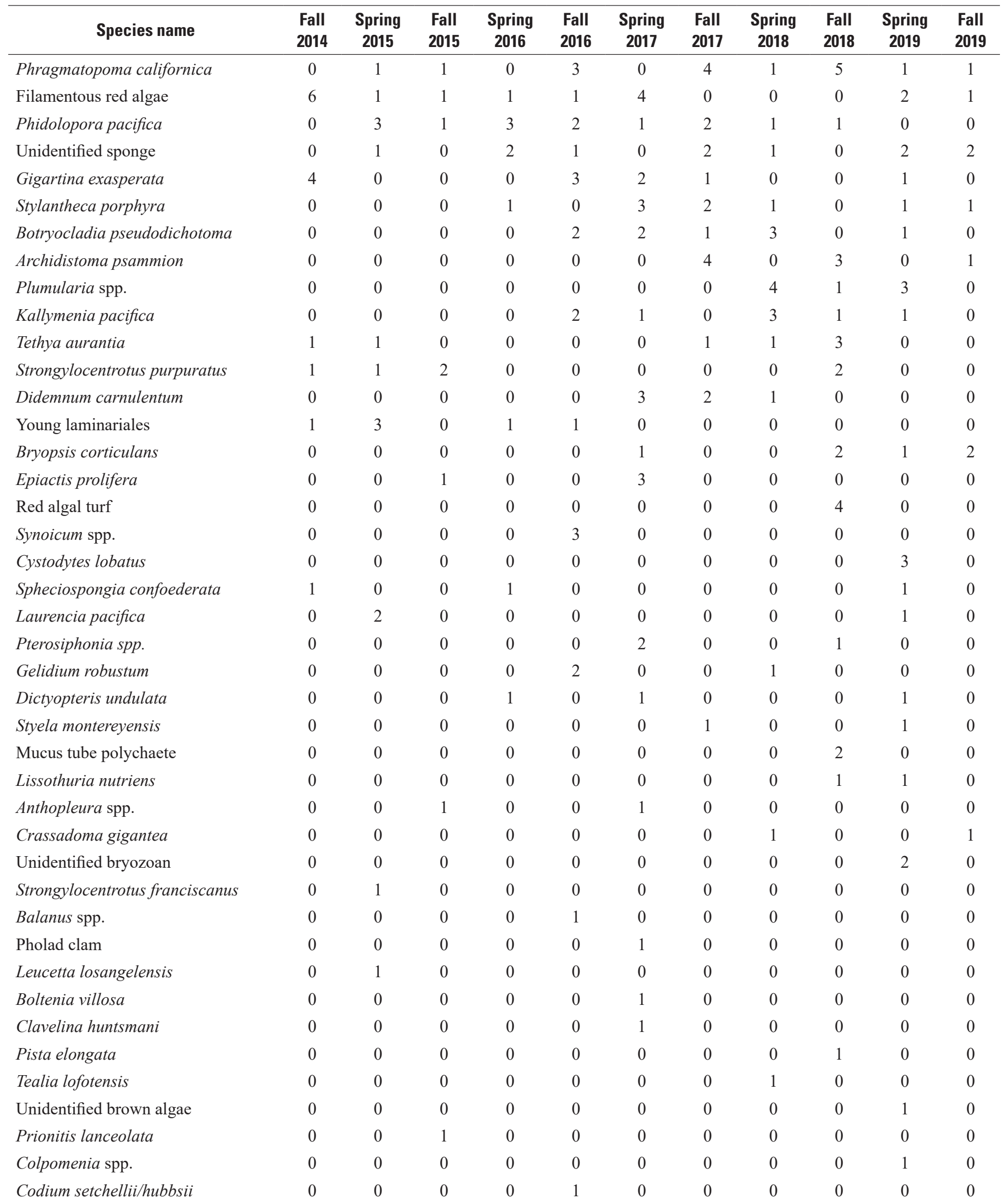


Table 23. Dutch Harbor point contact "species" ranked by the sum of points for fall 2014 through fall 2019._Continued

[>, greater than; $\mathrm{m}$, meter; $<$, less than]

\begin{tabular}{|c|c|c|c|c|c|c|c|c|c|c|c|}
\hline Species name & $\begin{array}{l}\text { Fall } \\
2014\end{array}$ & $\begin{array}{c}\text { Spring } \\
2015\end{array}$ & $\begin{array}{l}\text { Fall } \\
2015\end{array}$ & $\begin{array}{c}\text { Spring } \\
2016\end{array}$ & $\begin{array}{l}\text { Fall } \\
2016\end{array}$ & $\begin{array}{c}\text { Spring } \\
2017\end{array}$ & $\begin{array}{l}\text { Fall } \\
2017\end{array}$ & $\begin{array}{c}\text { Spring } \\
2018\end{array}$ & $\begin{array}{l}\text { Fall } \\
2018\end{array}$ & $\begin{array}{c}\text { Spring } \\
2019\end{array}$ & $\begin{array}{l}\text { Fall } \\
2019 \\
\end{array}$ \\
\hline Codium fragile & 1 & 0 & 0 & 0 & 0 & 0 & 0 & 0 & 0 & 0 & 0 \\
\hline Callophyllis flabellulata & 0 & 0 & 0 & 0 & 0 & 1 & 0 & 0 & 0 & 0 & 0 \\
\hline Desmarestia ligulata & 0 & 0 & 0 & 0 & 1 & 0 & 0 & 0 & 0 & 0 & 0 \\
\hline
\end{tabular}


Table 24. Dutch Harbor fish counts_Adult (Juvenile)—in fall 2014 through fall 2019 by species.

[f, female; $\mathrm{m}$, male]

\begin{tabular}{|c|c|c|c|c|c|c|c|c|c|c|c|}
\hline Species name & $\begin{array}{l}\text { Fall } \\
2014\end{array}$ & $\begin{array}{c}\text { Spring } \\
2015\end{array}$ & $\begin{array}{l}\text { Fall } \\
2015\end{array}$ & $\begin{array}{c}\text { Spring } \\
2016\end{array}$ & $\begin{array}{l}\text { Fall } \\
2016 \\
\end{array}$ & $\begin{array}{c}\text { Spring } \\
2017\end{array}$ & $\begin{array}{l}\text { Fall } \\
2017\end{array}$ & $\begin{array}{c}\text { Spring } \\
2018\end{array}$ & $\begin{array}{l}\text { Fall } \\
2018 \\
\end{array}$ & $\begin{array}{c}\text { Spring } \\
2019\end{array}$ & $\begin{array}{r}\text { Fall } \\
2019 \\
\end{array}$ \\
\hline Artedius spp. & 0 & 0 & 0 & 0 & 0 & 0 & 0 & 0 & 2 & 0 & 0 \\
\hline $\begin{array}{l}\text { Brachyistius } \\
\quad \text { frenatus }\end{array}$ & 52 & 5 & 18 & 2 & 31 & 0 & 3 & 10 & 5 & 4 & 10 \\
\hline $\begin{array}{l}\text { Caulolatilus } \\
\text { princeps }\end{array}$ & 0 & 0 & 0 & 1 & 0 & 0 & 4 & 0 & 0 & 4 & 4 \\
\hline $\begin{array}{c}\text { Cephaloscyllium } \\
\text { ventriosum }\end{array}$ & 0 & 0 & 0 & 4 & 0 & 0 & 0 & 0 & 0 & 0 & 0 \\
\hline $\begin{array}{l}\text { Chromis } \\
\quad \text { punctipinnis }\end{array}$ & 4,044 & $\begin{array}{l}1,435 \\
(405)\end{array}$ & 1,581 & 1,461 & $\begin{array}{c}1,711 \\
(70)\end{array}$ & 1,110 & 976 & 1,193 & 1,427 & 2,647 & $\begin{array}{c}1,007 \\
(55)\end{array}$ \\
\hline $\begin{array}{l}\text { Coryphopterus } \\
\text { nicholsii }\end{array}$ & 36 & 12 & 11 & 1 & 8 & 10 & 8 & 2 & 6 & 14 & 8 \\
\hline $\begin{array}{r}\text { Embiotoca } \\
\text { lateralis }\end{array}$ & 43 & $\begin{array}{l}21 \\
(3)\end{array}$ & 27 & 15 & 19 & 12 & 24 & 26 & 17 & 14 & 8 \\
\hline Gibbonsia spp. & 1 & 0 & 0 & 0 & 0 & 0 & 0 & 0 & 1 & 0 & 0 \\
\hline Girella nigricans & 53 & 27 & 39 & 18 & 28 & 48 & 105 & 23 & 45 & 26 & 65 \\
\hline $\begin{array}{l}\text { Halichoeres } \\
\text { semicinctus }\end{array}$ & 0 & 0 & 4 & 2 & 0 & 0 & 2 & 0 & 0 & 2 & 0 \\
\hline $\begin{array}{l}\text { Heterostichus } \\
\quad \text { rostratus }\end{array}$ & 0 & 0 & 0 & 0 & 0 & 0 & 0 & 0 & 0 & 0 & 1 \\
\hline Hypsurus caryi & 0 & 0 & 3 & 2 & 8 & 3 & 33 & 10 & 2 & 2 & 4 \\
\hline $\begin{array}{l}\text { Hypsypops } \\
\quad \text { rubicundus }\end{array}$ & $\begin{array}{l}17 \\
(4)\end{array}$ & 14 & $\begin{array}{l}23 \\
(1)\end{array}$ & 18 & $\begin{array}{l}26 \\
(1)\end{array}$ & 17 & 28 & 18 & 33 & 26 & $\begin{array}{l}18 \\
(1)\end{array}$ \\
\hline $\begin{array}{l}\text { Ophiodon } \\
\text { elongatus }\end{array}$ & 3 & 0 & 1 & 2 & 0 & 0 & 0 & 0 & 0 & 0 & 0 \\
\hline $\begin{array}{l}\text { Orthonopias } \\
\text { triacis }\end{array}$ & 0 & 0 & 0 & 0 & 0 & 0 & 0 & 0 & 0 & 0 & 1 \\
\hline $\begin{array}{l}\text { Oxyjulis } \\
\quad \text { californica }\end{array}$ & 3,742 & $\begin{array}{c}1,816 \\
(57)\end{array}$ & 1,068 & 237 & $\begin{array}{c}622 \\
(125)\end{array}$ & 548 & 239 & 683 & 130 & 137 & 244 \\
\hline Oxylebius pictus & 74 & $\begin{array}{l}50 \\
(1)\end{array}$ & 46 & 13 & 25 & 11 & 46 & 12 & 34 & 37 & $\begin{array}{l}24 \\
(1)\end{array}$ \\
\hline $\begin{array}{l}\text { Paralabrax } \\
\text { clathratus }\end{array}$ & 111 & $\begin{array}{c}41 \\
(29)\end{array}$ & 69 & 3 & 40 & 48 & 38 & 26 & 48 & 26 & 23 \\
\hline $\begin{array}{l}\text { Rhacochilus } \\
\text { toxotes }\end{array}$ & 7 & 0 & 1 & 1 & 1 & 0 & 7 & 1 & 1 & 1 & 1 \\
\hline Rhacochilus vacca & 17 & 6 & 27 & 8 & 17 & 10 & 13 & 13 & 14 & 5 & 8 \\
\hline Sardinops sagax & 0 & 0 & 170 & 0 & 0 & 0 & 0 & 0 & 0 & 0 & 0 \\
\hline $\begin{array}{l}\text { Scomber } \\
\quad \text { japonicus }\end{array}$ & 40 & 0 & 0 & 5 & 0 & 0 & 0 & 0 & 0 & 0 & 0 \\
\hline
\end{tabular}


Table 24. Dutch Harbor fish counts_Adult (Juvenile)—in fall 2014 through fall 2019 by species._Continued

[f, female; $m$, male]

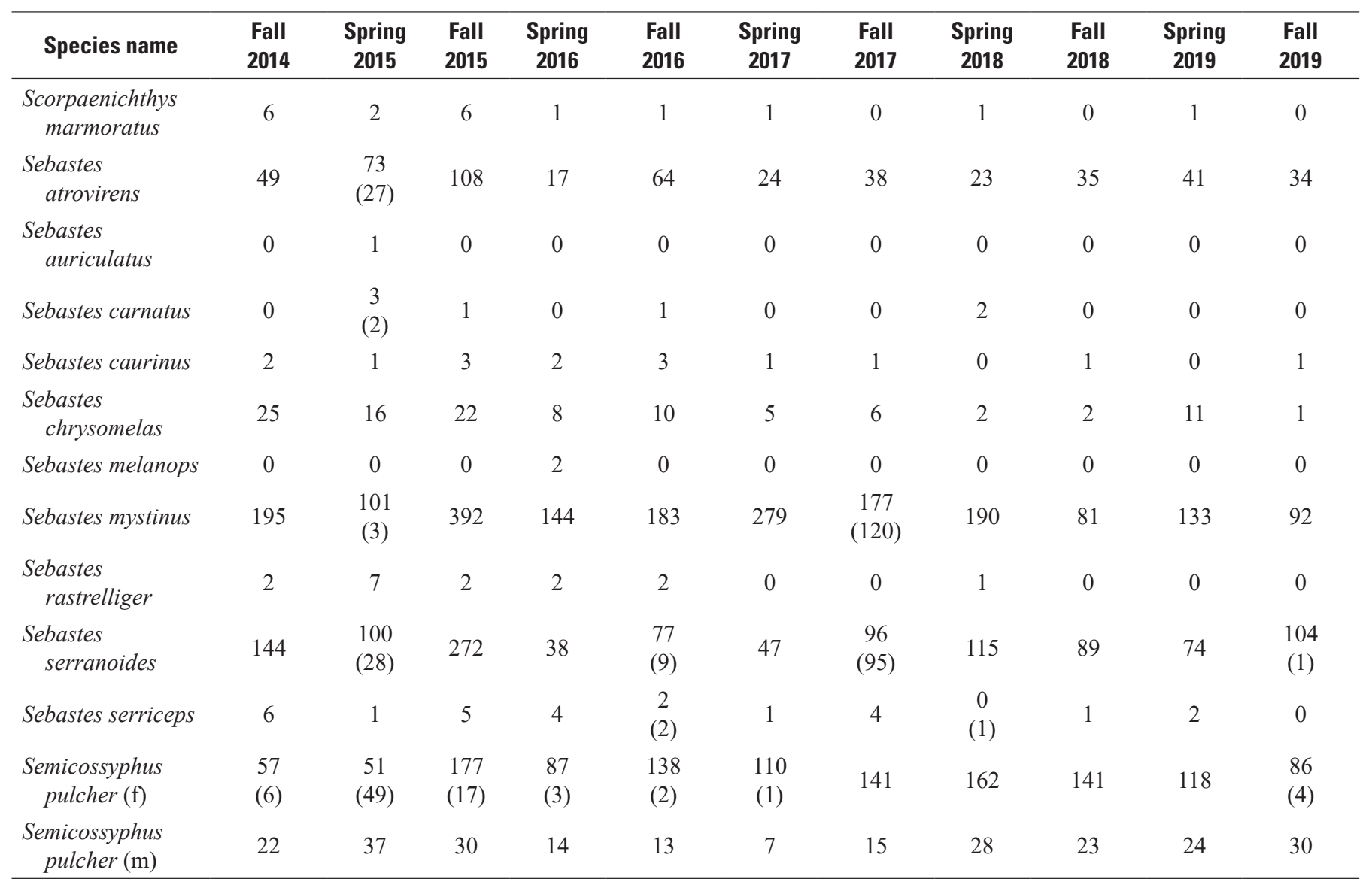


Dynamic swath counted species mean count, in 20 square meters $\left(\mathrm{m}^{2}\right)$-Daytona 100

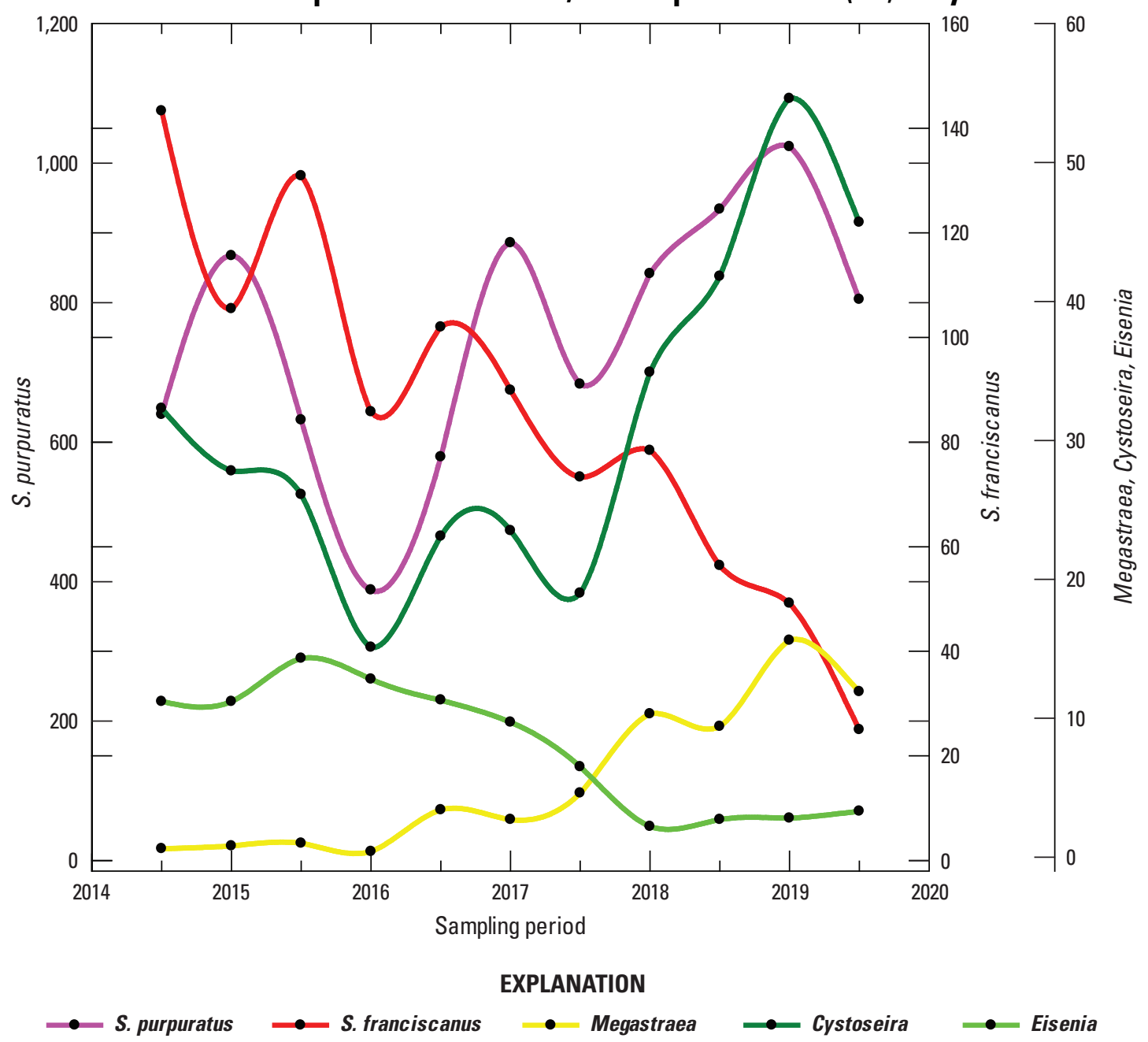

Figure 34. Mean densities of some swath-counted species that have demonstrated changing abundance at Daytona 100 from fall 2014 to fall 2019 (note three vertical axes for densities of different species groups). 


$$
\text { |ำ }
$$

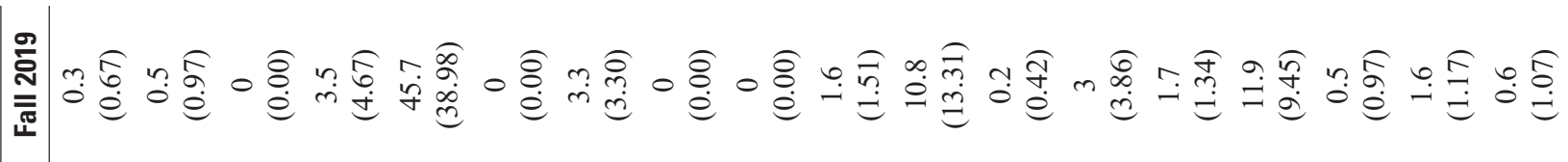

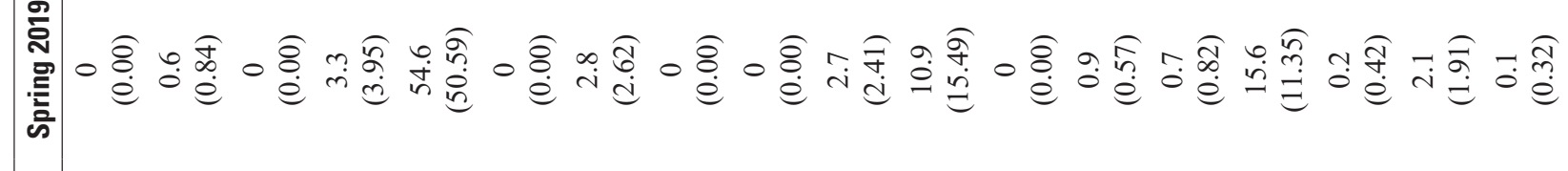

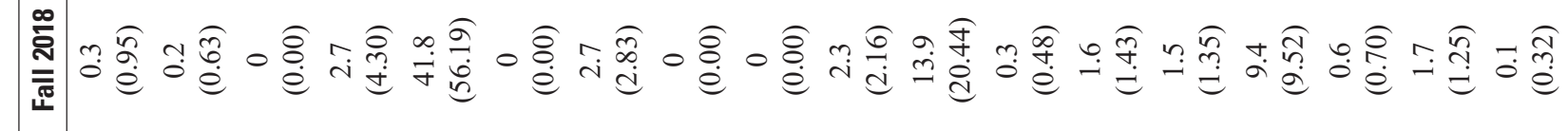

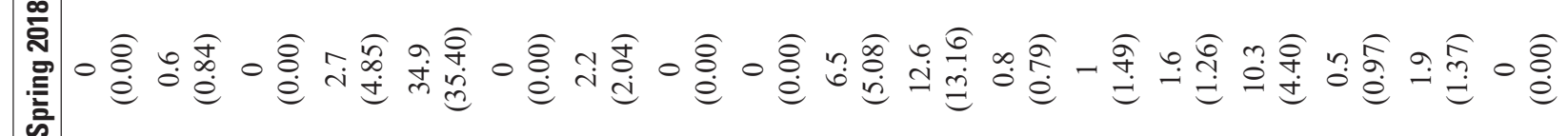

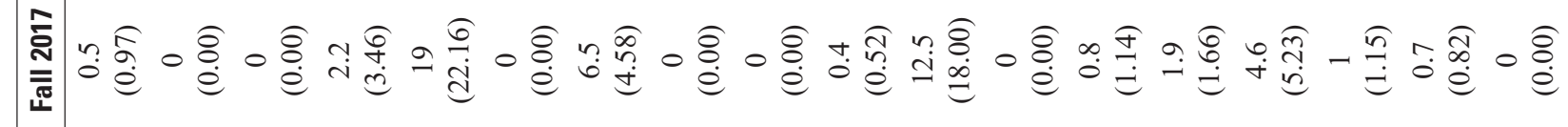

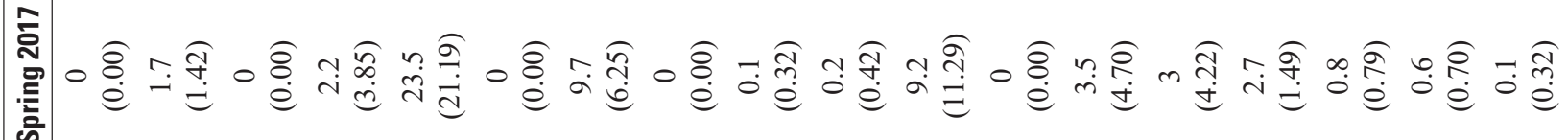

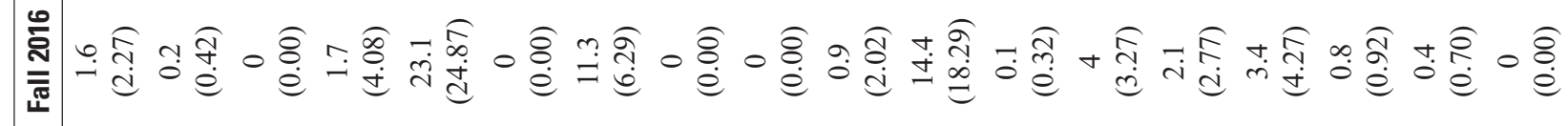

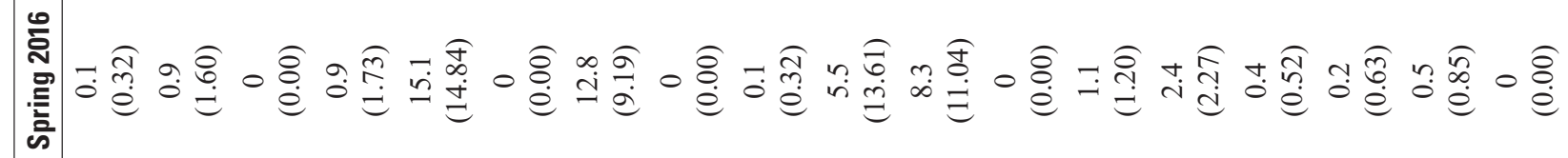

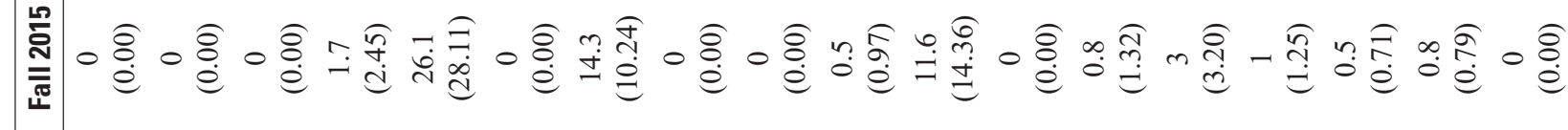

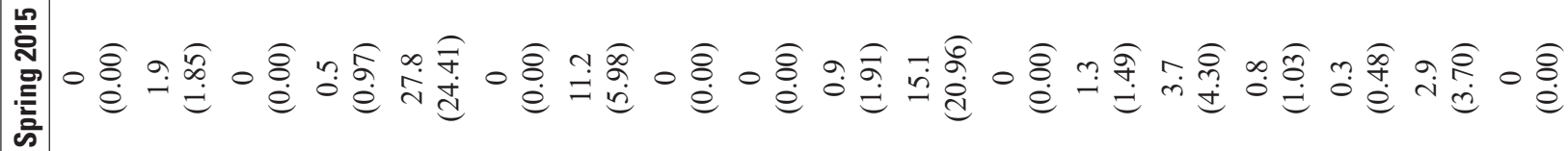

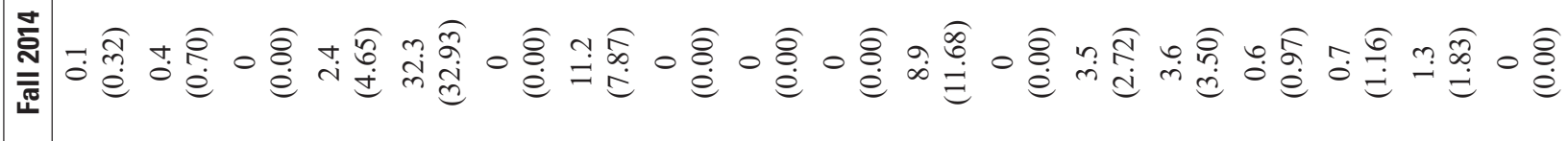




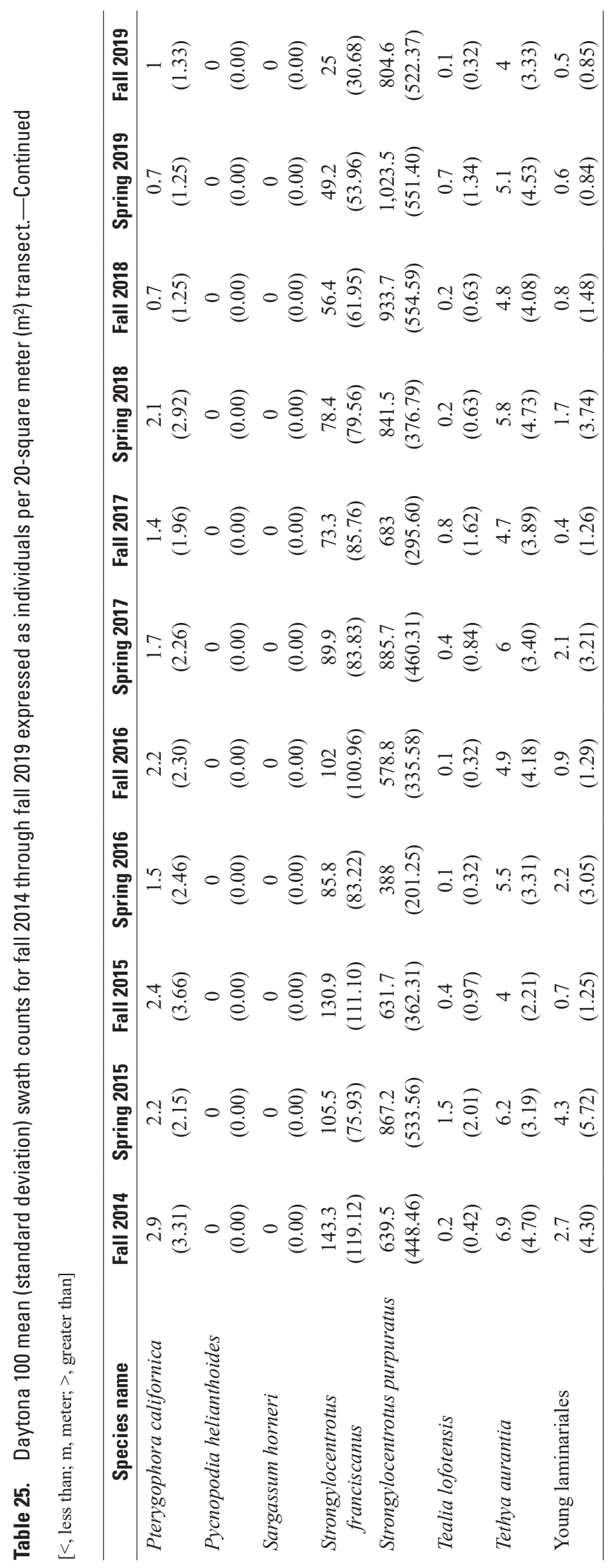




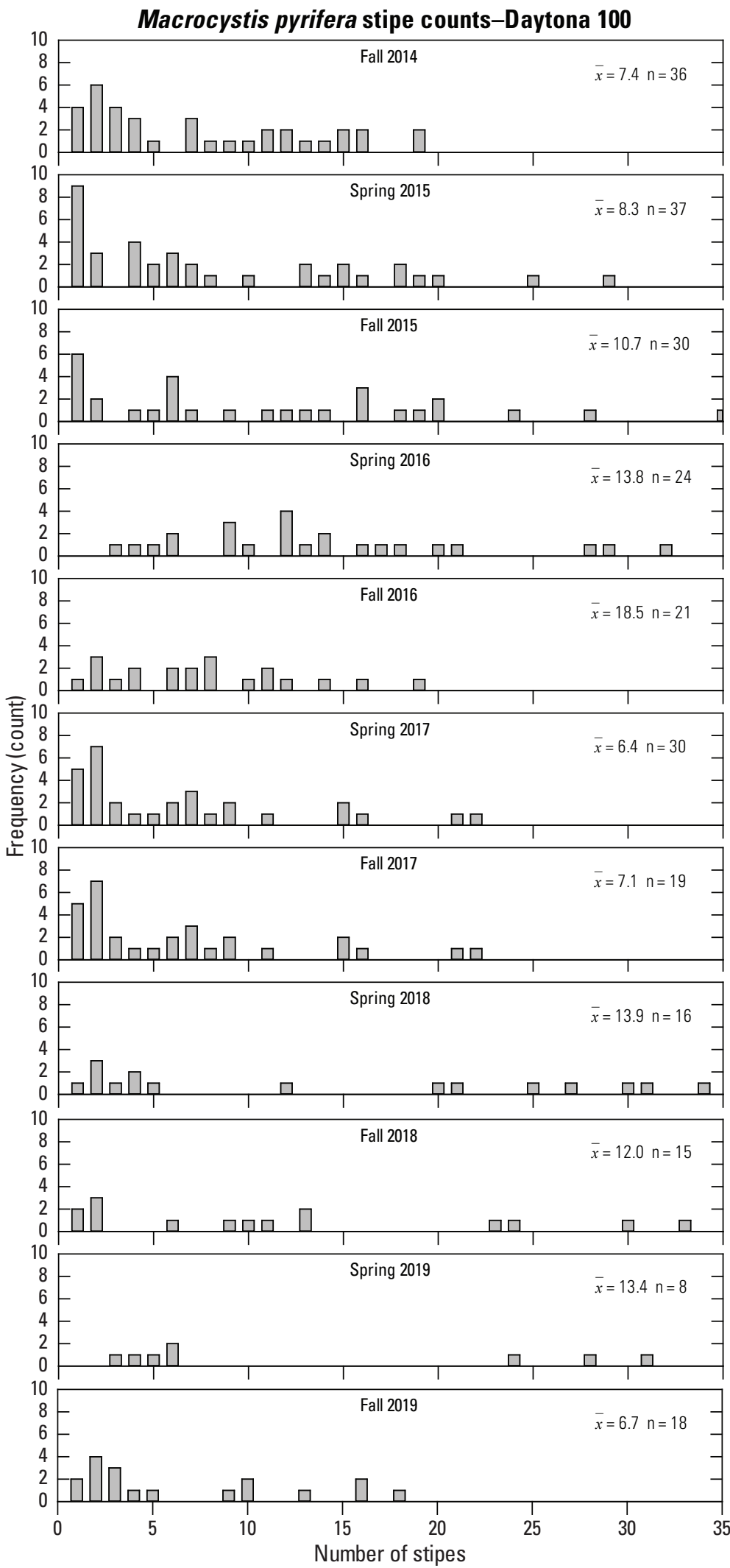

Figure 35. Daytona 100 Macrocystis pyrifera (greater than $1 \mathrm{~m}$ tall) stipe counts by season: Fall 2014-fall 2019 ( $\bar{x}$ is mean count, $\mathrm{n}$ is number of individuals). 


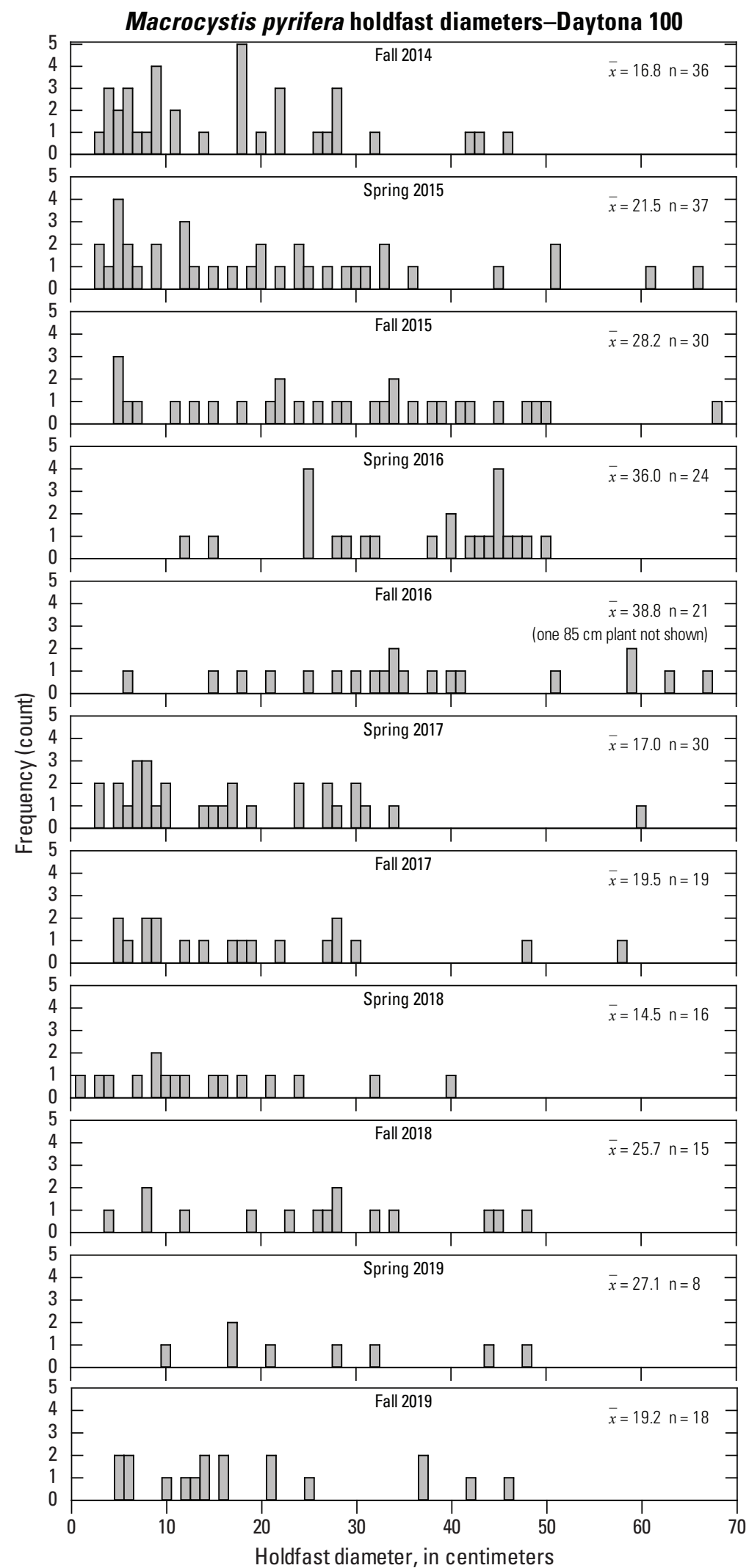

Figure 36. Daytona 100 Macrocystis pyrifera (greater than $1 \mathrm{~m}$ tall) holdfast diameters by season: Fall 2014-fall 2019 ( $\bar{x}$ is mean diameter, $\mathrm{n}$ is number of individuals). 
Table 26. Sizes of invertebrates measured on swaths at Daytona 100, fall 2014 through fall 2019.

[Strongylocentrotus spp. excluded. See figures 39 and 40 for purple and red urchin size data. Abbreviations: N, sample size; Min, minimum; - , no data; Max, maximum]

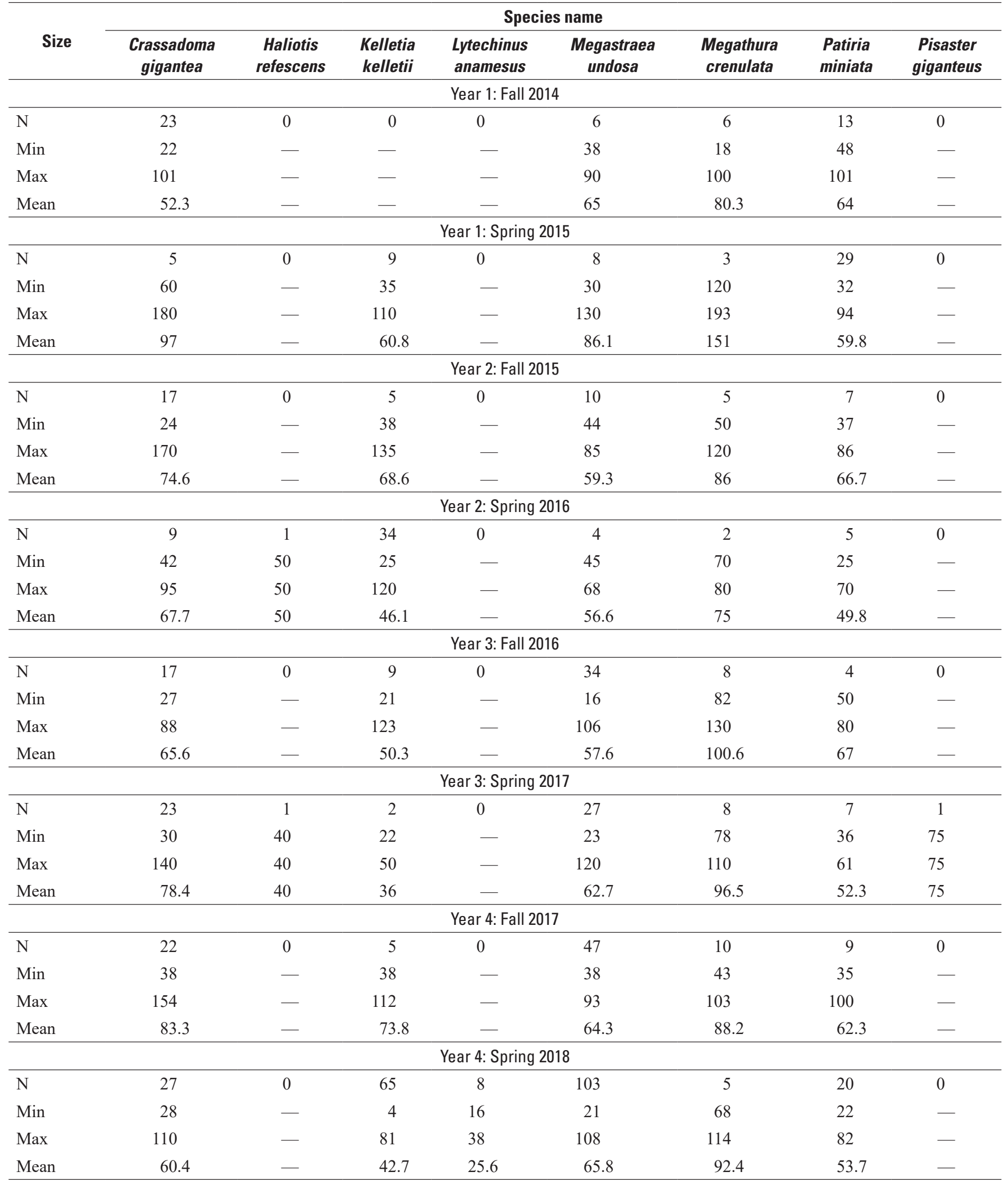




\section{Kelp Forest Monitoring at Naval Base Ventura County, San Nicolas Island, California}

Table 26. Sizes of invertebrates measured on swaths at Daytona 100, fall 2014 through fall 2019.—Continued

[Strongylocentrotus spp. excluded. See figures 39 and 40 for purple and red urchin size data. Abbreviations: N, sample size; Min, minimum; -, no data; Max, maximum]

\begin{tabular}{|c|c|c|c|c|c|c|c|c|}
\hline \multirow[b]{2}{*}{ Size } & \multicolumn{8}{|c|}{ Species name } \\
\hline & $\begin{array}{c}\text { Crassadoma } \\
\text { gigantea }\end{array}$ & $\begin{array}{c}\text { Haliotis } \\
\text { refescens }\end{array}$ & $\begin{array}{c}\text { Kelletia } \\
\text { kelletii }\end{array}$ & $\begin{array}{l}\text { Lytechinus } \\
\text { anamesus }\end{array}$ & $\begin{array}{c}\text { Megastraea } \\
\text { undosa }\end{array}$ & $\begin{array}{c}\text { Megathura } \\
\text { crenulata }\end{array}$ & $\begin{array}{l}\text { Patiria } \\
\text { miniata }\end{array}$ & $\begin{array}{c}\text { Pisaster } \\
\text { giganteus }\end{array}$ \\
\hline $\mathrm{N}$ & 27 & 0 & 23 & 0 & 94 & 6 & 17 & 1 \\
\hline Min & 20 & - & 31 & - & 32 & 88 & 34 & 78 \\
\hline \multicolumn{9}{|c|}{ Year 5: Spring 2019} \\
\hline $\mathrm{N}$ & 33 & 0 & 27 & 0 & 156 & 2 & 15 & 1 \\
\hline Min & 40 & - & 31 & - & 24 & 91 & 25 & 92 \\
\hline Max & 180 & - & 91 & - & 101 & 121 & 84 & 92 \\
\hline Min & 30 & - & 48 & - & 40 & 92 & 21 & 58 \\
\hline Max & 120 & - & 81 & - & 95 & 120 & 90 & 120 \\
\hline Mean & 74.7 & - & 65.5 & - & 67.7 & 107 & 58.9 & 76.3 \\
\hline
\end{tabular}




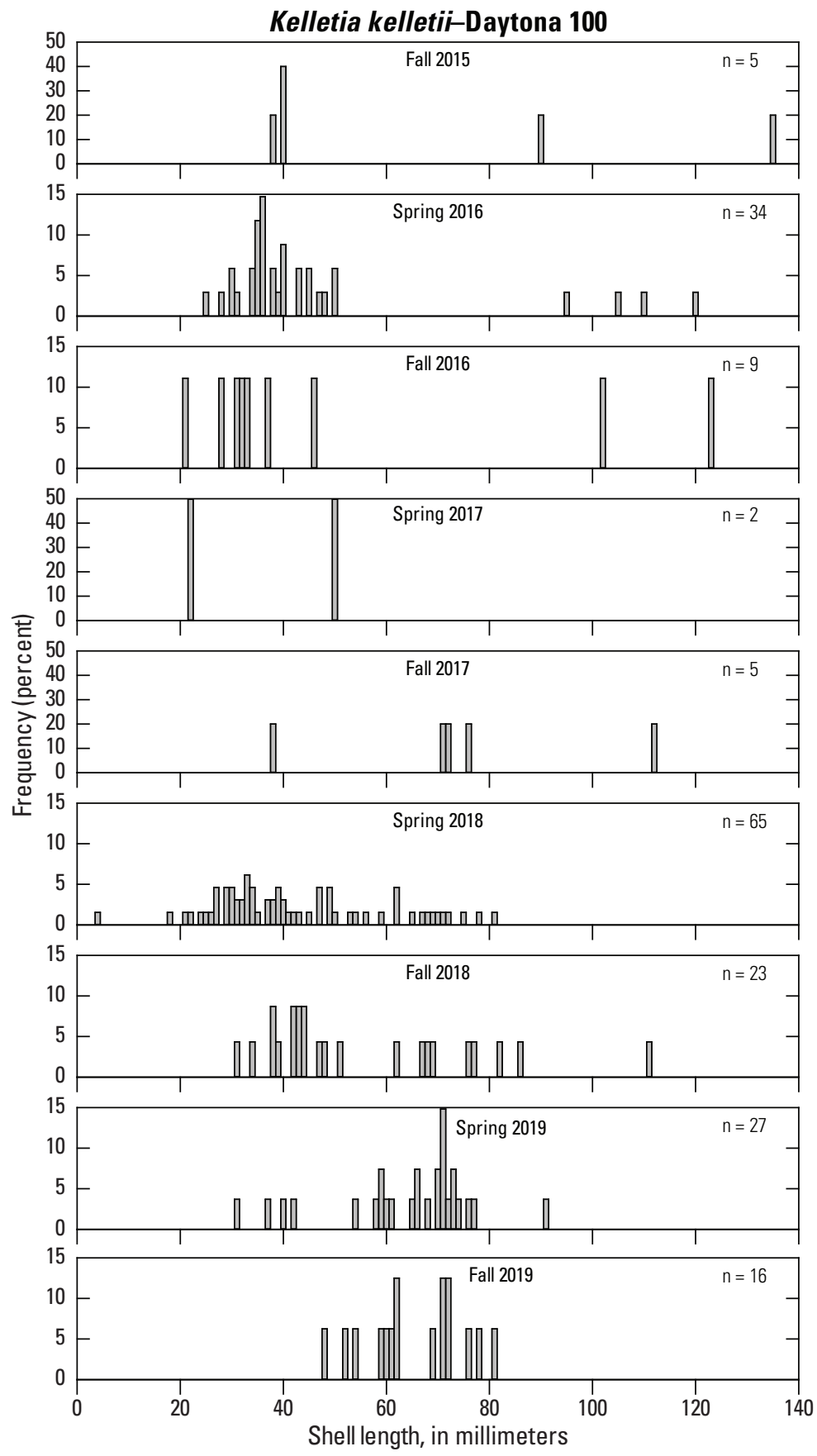

Figure 37. Size structure of Kelletia kelletii (Kellet's whelk) at Daytona 100 fall 2015-fall 2019 ( $n=$ number of individuals). 


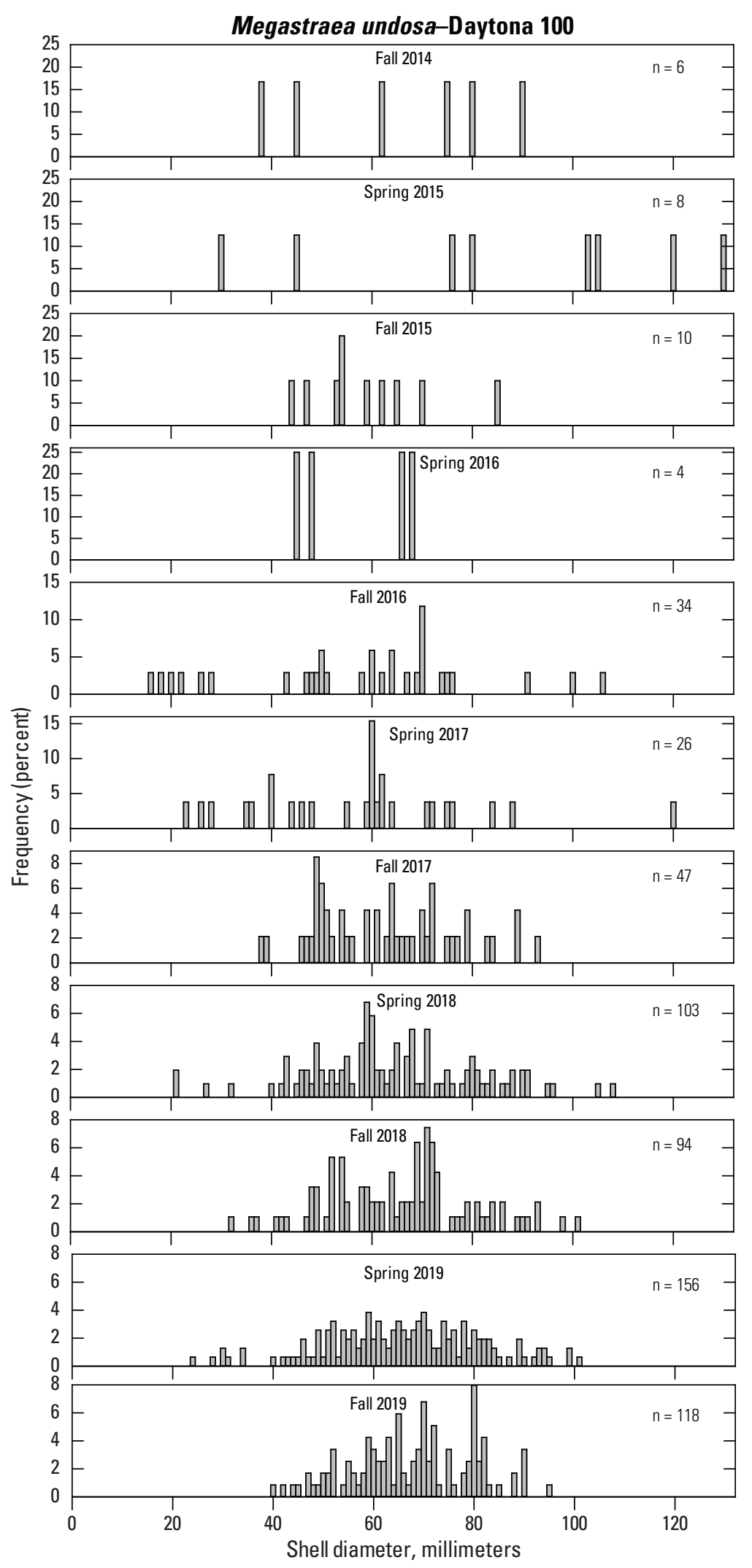

Figure 38. Daytona 100 size structure of Megastraea undosa (wavy turban snails) in fall 2014-fall 2019 (Note different frequency scales. $n=$ number of individuals). 
Table 27. Daytona 100 mean of the species counted in twenty 1-m² quadrats for fall 2014 through fall 2019.

\begin{tabular}{|c|c|c|c|c|c|c|c|c|c|c|c|}
\hline Species name & $\begin{array}{l}\text { Fall } \\
2014\end{array}$ & $\begin{array}{c}\text { Spring } \\
2015\end{array}$ & $\begin{array}{l}\text { Fall } \\
2015\end{array}$ & $\begin{array}{c}\text { Spring } \\
2016\end{array}$ & $\begin{array}{l}\text { Fall } \\
2016\end{array}$ & $\begin{array}{c}\text { Spring } \\
2017\end{array}$ & $\begin{array}{l}\text { Fall } \\
2017\end{array}$ & $\begin{array}{c}\text { Spring } \\
2018\end{array}$ & $\begin{array}{l}\text { Fall } \\
2018\end{array}$ & $\begin{array}{c}\text { Spring } \\
2019\end{array}$ & $\begin{array}{c}\text { Fall } \\
2019\end{array}$ \\
\hline Lithopoma gibberosa & $\begin{array}{c}0.0 \\
(0.00)\end{array}$ & $\begin{array}{c}0.0 \\
(0.00)\end{array}$ & $\begin{array}{c}0.0 \\
(0.00)\end{array}$ & $\begin{array}{c}0.0 \\
(0.00)\end{array}$ & $\begin{array}{c}0.0 \\
(0.00)\end{array}$ & $\begin{array}{c}0.0 \\
(0.00)\end{array}$ & $\begin{array}{c}0.0 \\
(0.00)\end{array}$ & $\begin{array}{c}0.0 \\
(0.00)\end{array}$ & $\begin{array}{c}0.0 \\
(0.00)\end{array}$ & $\begin{array}{c}0.0 \\
(0.00)\end{array}$ & $\begin{array}{c}0.0 \\
(0.00)\end{array}$ \\
\hline Cypraea spadicea & $\begin{array}{c}0.0 \\
(0.00)\end{array}$ & $\begin{array}{c}0.0 \\
(0.00)\end{array}$ & $\begin{array}{c}0.1 \\
(0.22)\end{array}$ & $\begin{array}{c}0.0 \\
(0.00)\end{array}$ & $\begin{array}{c}0.2 \\
(0.37)\end{array}$ & $\begin{array}{c}0.0 \\
(0.00)\end{array}$ & $\begin{array}{c}0.1 \\
(0.22)\end{array}$ & $\begin{array}{c}0.0 \\
(0.00)\end{array}$ & $\begin{array}{c}0.0 \\
(0.00)\end{array}$ & $\begin{array}{c}0.0 \\
(0.00)\end{array}$ & $\begin{array}{c}0.0 \\
(0.00)\end{array}$ \\
\hline Kelletia kelletii & $\begin{array}{c}0.0 \\
(0.00)\end{array}$ & $\begin{array}{c}0.0 \\
(0.00)\end{array}$ & $\begin{array}{c}0.0 \\
(0.00)\end{array}$ & $\begin{array}{c}0.0 \\
(0.00)\end{array}$ & $\begin{array}{c}0.1 \\
(0.31)\end{array}$ & $\begin{array}{c}0.1 \\
(0.22)\end{array}$ & $\begin{array}{c}0.0 \\
(0.00)\end{array}$ & $\begin{array}{c}0.0 \\
(0.00)\end{array}$ & $\begin{array}{c}0.0 \\
(0.00)\end{array}$ & $\begin{array}{c}0.1 \\
(0.22)\end{array}$ & $\begin{array}{c}0.0 \\
(0.00)\end{array}$ \\
\hline Norrisia norrisi & $\begin{array}{c}0.0 \\
(0.00)\end{array}$ & $\begin{array}{c}0.1 \\
(0.22)\end{array}$ & $\begin{array}{c}0.0 \\
(0.00)\end{array}$ & $\begin{array}{c}0.1 \\
(0.22)\end{array}$ & $\begin{array}{c}0.0 \\
(0.00)\end{array}$ & $\begin{array}{c}0.1 \\
(0.22)\end{array}$ & $\begin{array}{c}0.2 \\
(0.49)\end{array}$ & $\begin{array}{c}0.1 \\
(0.31)\end{array}$ & $\begin{array}{c}0.0 \\
(0.00)\end{array}$ & $\begin{array}{c}0.0 \\
(0.00)\end{array}$ & $\begin{array}{c}0.0 \\
(0.00)\end{array}$ \\
\hline Sargassum horneri & $\begin{array}{c}0.0 \\
(0.00)\end{array}$ & $\begin{array}{c}0.0 \\
(0.00)\end{array}$ & $\begin{array}{c}0.0 \\
(0.00)\end{array}$ & $\begin{array}{c}0.0 \\
(0.00)\end{array}$ & $\begin{array}{c}0.0 \\
(0.00)\end{array}$ & $\begin{array}{c}0.0 \\
(0.00)\end{array}$ & $\begin{array}{c}0.0 \\
(0.00)\end{array}$ & $\begin{array}{c}0.0 \\
(0.00)\end{array}$ & $\begin{array}{c}0.0 \\
(0.00)\end{array}$ & $\begin{array}{c}0.0 \\
(0.00)\end{array}$ & $\begin{array}{c}0.0 \\
(0.00)\end{array}$ \\
\hline Styela montereyensis & $\begin{array}{c}0.0 \\
(0.00)\end{array}$ & $\begin{array}{c}0.0 \\
(0.00)\end{array}$ & $\begin{array}{c}0.0 \\
(0.00)\end{array}$ & $\begin{array}{c}0.1 \\
(0.22)\end{array}$ & $\begin{array}{c}0.0 \\
(0.00)\end{array}$ & $\begin{array}{c}0.0 \\
(0.00)\end{array}$ & $\begin{array}{c}0.0 \\
(0.00)\end{array}$ & $\begin{array}{c}0.0 \\
(0.00)\end{array}$ & $\begin{array}{c}0.0 \\
(0.00)\end{array}$ & $\begin{array}{c}0.0 \\
(0.00)\end{array}$ & $\begin{array}{c}0.0 \\
(0.00)\end{array}$ \\
\hline Tethya aurantia & $\begin{array}{c}0.1 \\
(0.31)\end{array}$ & $\begin{array}{c}0.3 \\
(0.57)\end{array}$ & $\begin{array}{c}0.3 \\
(0.64)\end{array}$ & $\begin{array}{c}0.5 \\
(0.83)\end{array}$ & $\begin{array}{c}0.2 \\
(0.37)\end{array}$ & $\begin{array}{c}0.3 \\
(0.64)\end{array}$ & $\begin{array}{c}0.2 \\
(0.37)\end{array}$ & $\begin{array}{c}0.3 \\
(0.55)\end{array}$ & $\begin{array}{c}0.2 \\
(0.52)\end{array}$ & $\begin{array}{c}0.2 \\
(0.37)\end{array}$ & $\begin{array}{c}0.1 \\
(0.22)\end{array}$ \\
\hline Tealia lofotensis & $\begin{array}{c}0.0 \\
(0.00)\end{array}$ & $\begin{array}{c}0.0 \\
(0.00)\end{array}$ & $\begin{array}{c}0.0 \\
(0.00)\end{array}$ & $\begin{array}{c}0.0 \\
(0.00)\end{array}$ & $\begin{array}{c}0.0 \\
(0.00)\end{array}$ & $\begin{array}{c}0.0 \\
(0.00)\end{array}$ & $\begin{array}{c}0.0 \\
(0.00)\end{array}$ & $\begin{array}{c}0.0 \\
(0.00)\end{array}$ & $\begin{array}{c}0.0 \\
(0.00)\end{array}$ & $\begin{array}{c}0.0 \\
(0.00)\end{array}$ & $\begin{array}{c}0.0 \\
(0.00)\end{array}$ \\
\hline
\end{tabular}




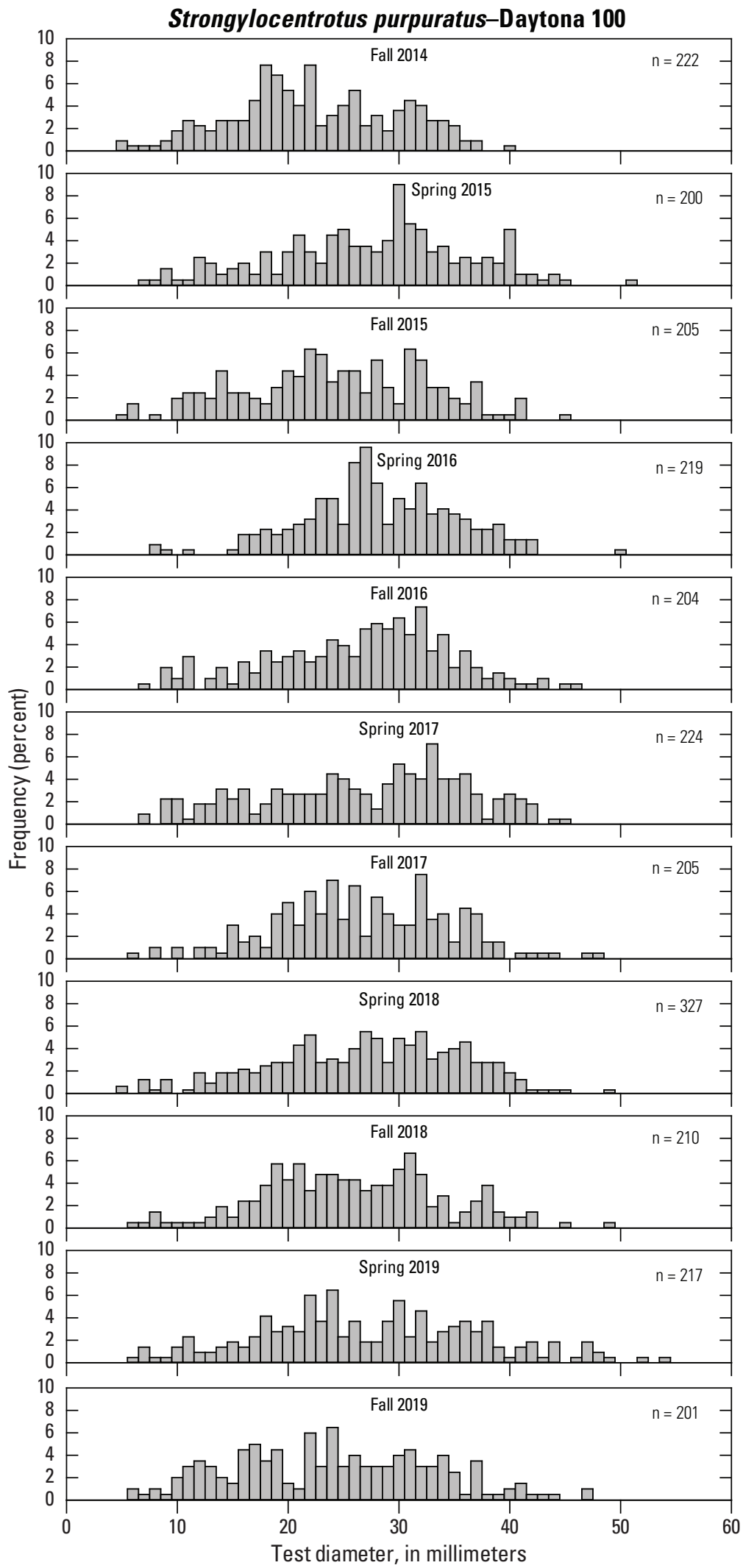

Figure 39. Daytona 100 size structure of Strongylocentrotus purpuratus (purple urchins) in fall 2014-fall 2019 (n=number of individuals). 


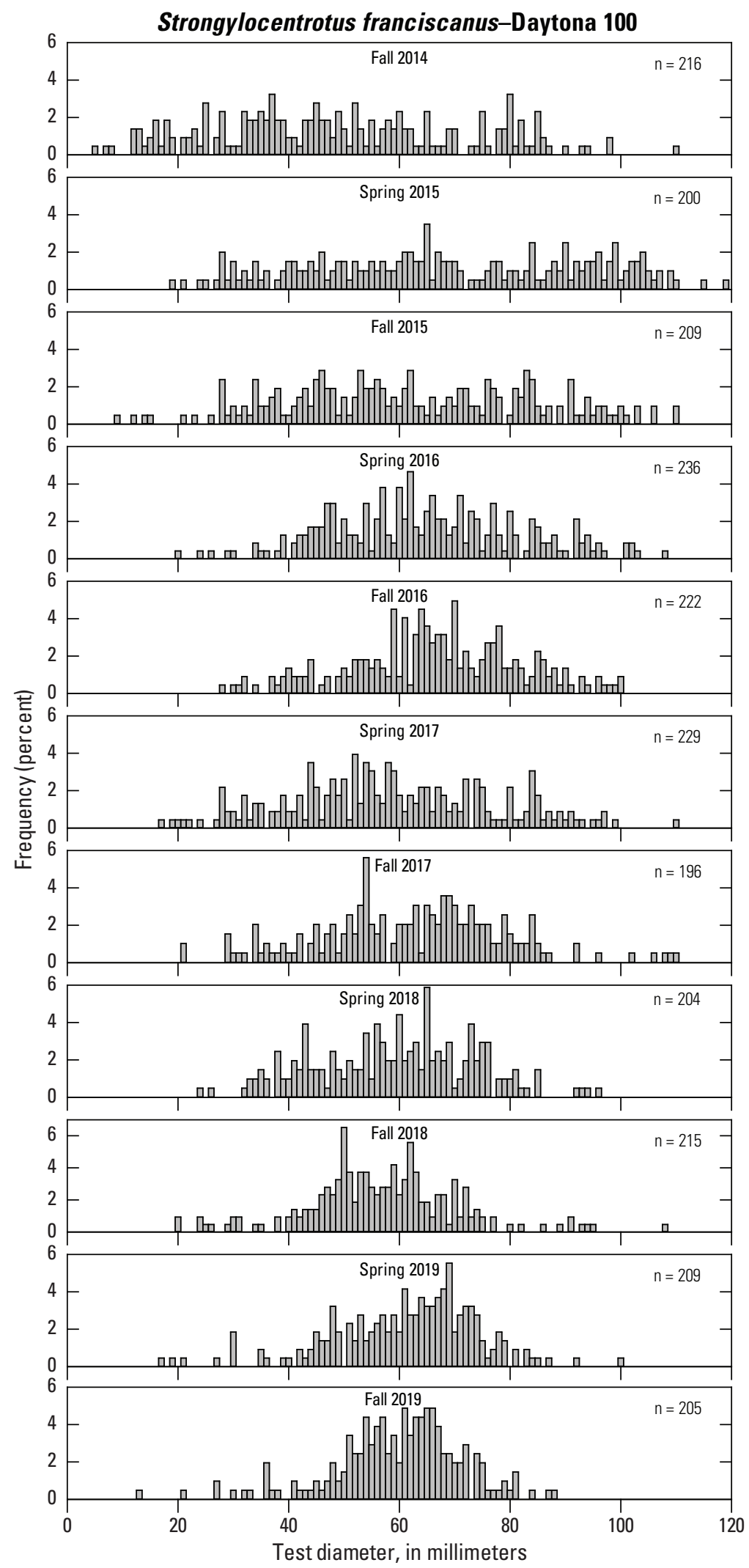

Figure 40. Daytona 100 size structure of Strongylocentrotus franciscanus (red urchins) in fall 2014-fall 2019 ( $\mathrm{n=number}$ of individuals). 
Table 28. Daytona 100 point contact "species" ranked by the sum of points for fall 2014 through fall 2019.

[ $>$, greater than; $\mathrm{m}$, meter; $<$, less than]

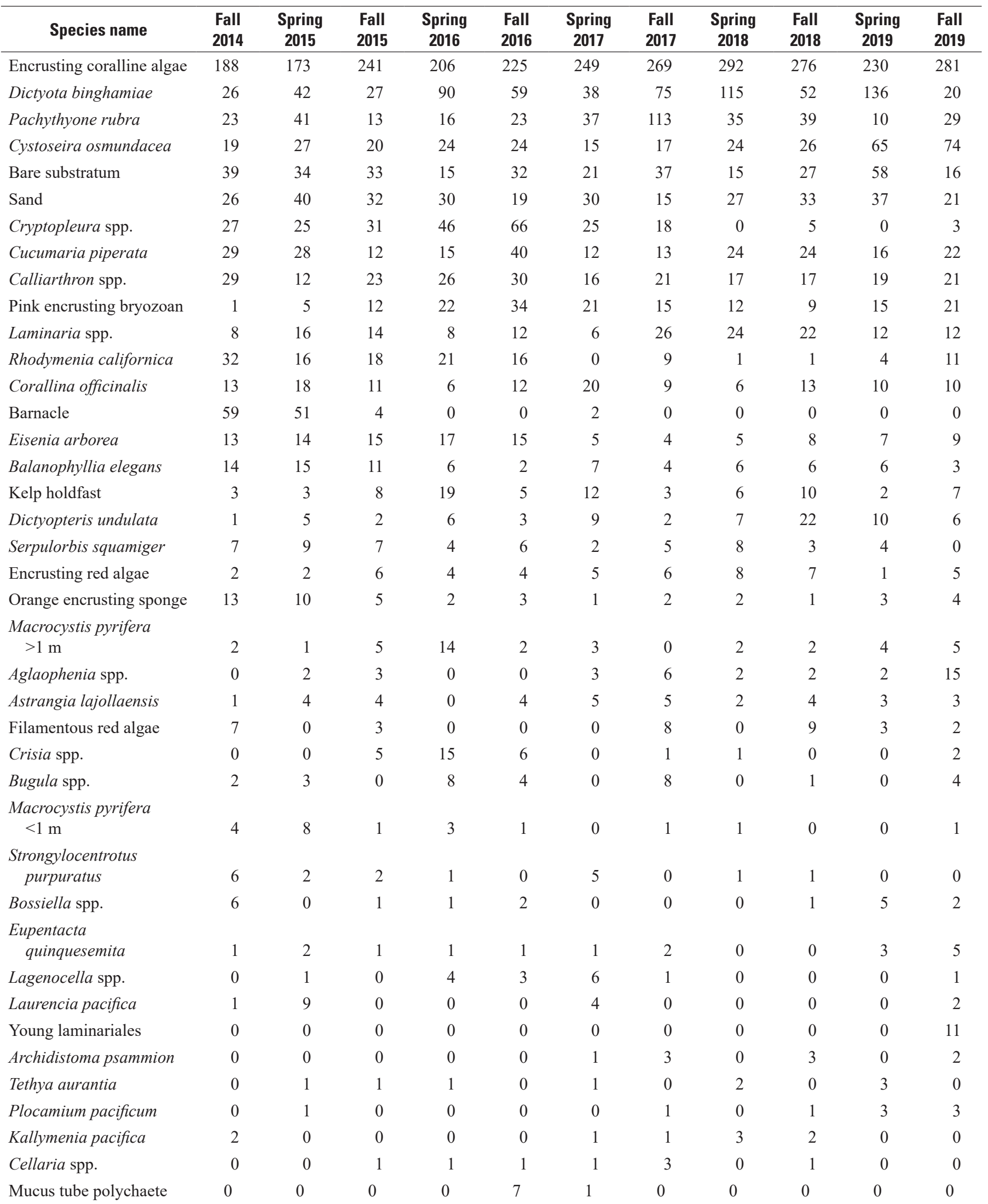


Table 28. Daytona 100 point contact "species" ranked by the sum of points for fall 2014 through fall 2019.-Continued

$[>$, greater than; $\mathrm{m}$, meter; $<$, less than]

\begin{tabular}{|c|c|c|c|c|c|c|c|c|c|c|c|}
\hline Species name & $\begin{array}{l}\text { Fall } \\
2014\end{array}$ & $\begin{array}{l}\text { Spring } \\
2015\end{array}$ & $\begin{array}{l}\text { Fall } \\
2015\end{array}$ & $\begin{array}{l}\text { Spring } \\
2016\end{array}$ & $\begin{array}{l}\text { Fall } \\
2016\end{array}$ & $\begin{array}{l}\text { Spring } \\
2017\end{array}$ & $\begin{array}{l}\text { Fall } \\
2017\end{array}$ & $\begin{array}{l}\text { Spring } \\
2018\end{array}$ & $\begin{array}{l}\text { Fall } \\
2018\end{array}$ & $\begin{array}{c}\text { Spring } \\
2019\end{array}$ & $\begin{array}{l}\text { Fall } \\
2019\end{array}$ \\
\hline Pterygophora californica & 0 & 0 & 0 & 0 & 2 & 0 & 1 & 1 & 0 & 2 & 2 \\
\hline $\begin{array}{l}\text { Strongylocentrotus } \\
\text { franciscanus }\end{array}$ & 1 & 0 & 3 & 0 & 1 & 0 & 0 & 1 & 1 & 0 & 0 \\
\hline Corynactis californica & 0 & 3 & 0 & 1 & 0 & 0 & 0 & 0 & 0 & 1 & 1 \\
\hline Diopatra ornata & 1 & 0 & 0 & 0 & 1 & 0 & 1 & 0 & 2 & 0 & 1 \\
\hline Hippodiplosia insculpta & 0 & 0 & 0 & 3 & 0 & 1 & 0 & 0 & 0 & 0 & 2 \\
\hline Dodecaceria spp. & 1 & 2 & 1 & 1 & 0 & 0 & 1 & 0 & 0 & 0 & 0 \\
\hline Filamentous green algae & 1 & 0 & 1 & 3 & 1 & 0 & 0 & 0 & 0 & 0 & 0 \\
\hline Abietinaria spp. & 0 & 0 & 1 & 0 & 0 & 0 & 0 & 1 & 1 & 0 & 2 \\
\hline Metandrocarpa dura & 0 & 0 & 0 & 4 & 0 & 0 & 0 & 0 & 1 & 0 & 0 \\
\hline Didemnum carnulentum & 1 & 1 & 0 & 2 & 0 & 0 & 0 & 0 & 0 & 0 & 1 \\
\hline Nienburgia andersoniana & 0 & 1 & 0 & 2 & 1 & 0 & 1 & 0 & 0 & 0 & 0 \\
\hline Acarnus erithacus & 0 & 1 & 0 & 0 & 2 & 0 & 0 & 0 & 1 & 0 & 0 \\
\hline Sargassum muticum & 0 & 0 & 1 & 0 & 0 & 0 & 0 & 1 & 0 & 1 & 1 \\
\hline Synoicum spp. & 0 & 0 & 0 & 0 & 0 & 0 & 0 & 0 & 0 & 3 & 0 \\
\hline Pholad clam & 0 & 0 & 0 & 0 & 1 & 1 & 0 & 0 & 0 & 1 & 0 \\
\hline $\begin{array}{r}\text { Spheciospongia } \\
\text { confoederata }\end{array}$ & 2 & 1 & 0 & 0 & 0 & 0 & 0 & 0 & 0 & 0 & 0 \\
\hline Lissothuria nutriens & 0 & 0 & 0 & 0 & 0 & 0 & 0 & 0 & 2 & 1 & 0 \\
\hline Bryopsis corticulans & 0 & 0 & 0 & 0 & 0 & 2 & 0 & 0 & 0 & 0 & 1 \\
\hline Anthopleura sola & 0 & 0 & 0 & 0 & 0 & 0 & 1 & 0 & 0 & 1 & 0 \\
\hline Balanus spp. & 0 & 0 & 0 & 0 & 0 & 0 & 0 & 0 & 1 & 1 & 0 \\
\hline Cucumaria salma & 0 & 1 & 0 & 0 & 0 & 0 & 0 & 0 & 0 & 1 & 0 \\
\hline Cystodytes lobatus & 0 & 0 & 0 & 1 & 0 & 0 & 0 & 1 & 0 & 0 & 0 \\
\hline Plumularia spp. & 0 & 0 & 0 & 0 & 0 & 0 & 0 & 0 & 0 & 1 & 1 \\
\hline Colpomenia spp. & 1 & 0 & 0 & 0 & 0 & 0 & 1 & 0 & 0 & 0 & 0 \\
\hline Dodecaceria fewkesi & 0 & 0 & 0 & 0 & 0 & 0 & 0 & 0 & 0 & 1 & 0 \\
\hline $\begin{array}{l}\text { Phragmatopoma } \\
\text { californica }\end{array}$ & 0 & 0 & 0 & 0 & 0 & 0 & 0 & 1 & 0 & 0 & 0 \\
\hline $\begin{array}{l}\text { Hymenamphiastra } \\
\text { cyanocrypta }\end{array}$ & 0 & 0 & 0 & 0 & 0 & 1 & 0 & 0 & 0 & 0 & 0 \\
\hline Unidentified sponge & 0 & 0 & 0 & 0 & 0 & 0 & 0 & 0 & 0 & 1 & 0 \\
\hline Stylantheca porphyra & 0 & 0 & 0 & 1 & 0 & 0 & 0 & 0 & 0 & 0 & 0 \\
\hline Phidolopora pacifica & 0 & 1 & 0 & 0 & 0 & 0 & 0 & 0 & 0 & 0 & 0 \\
\hline Leucosolenia eleanor & 0 & 0 & 0 & 0 & 0 & 0 & 0 & 0 & 1 & 0 & 0 \\
\hline Spirobranchus spinosus & 0 & 0 & 0 & 0 & 0 & 0 & 1 & 0 & 0 & 0 & 0 \\
\hline Crassadoma gigantea & 0 & 0 & 0 & 0 & 1 & 0 & 0 & 0 & 0 & 0 & 0 \\
\hline Taonia lennebackerae & 1 & 0 & 0 & 0 & 0 & 0 & 0 & 0 & 0 & 0 & 0 \\
\hline Polysiphonia spp. & 0 & 0 & 0 & 0 & 0 & 0 & 1 & 0 & 0 & 0 & 0 \\
\hline Codium setchellii/hubbsii & 0 & 1 & 0 & 0 & 0 & 0 & 0 & 0 & 0 & 0 & 0 \\
\hline Pterosiphonia spp. & 0 & 0 & 0 & 0 & 1 & 0 & 0 & 0 & 0 & 0 & 0 \\
\hline Red algal turf & 0 & 0 & 0 & 0 & 0 & 1 & 0 & 0 & 0 & 0 & 0 \\
\hline Opuntiella californica & 0 & 0 & 0 & 0 & 0 & 0 & 1 & 0 & 0 & 0 & 0 \\
\hline Gigartina exasperata & 1 & 0 & 0 & 0 & 0 & 0 & 0 & 0 & 0 & 0 & 0 \\
\hline
\end{tabular}


Table 29. Daytona 100 fish counts-Adult (Juvenile) —in fall 2014 through fall 2019 by species.

[f, female; m, male]

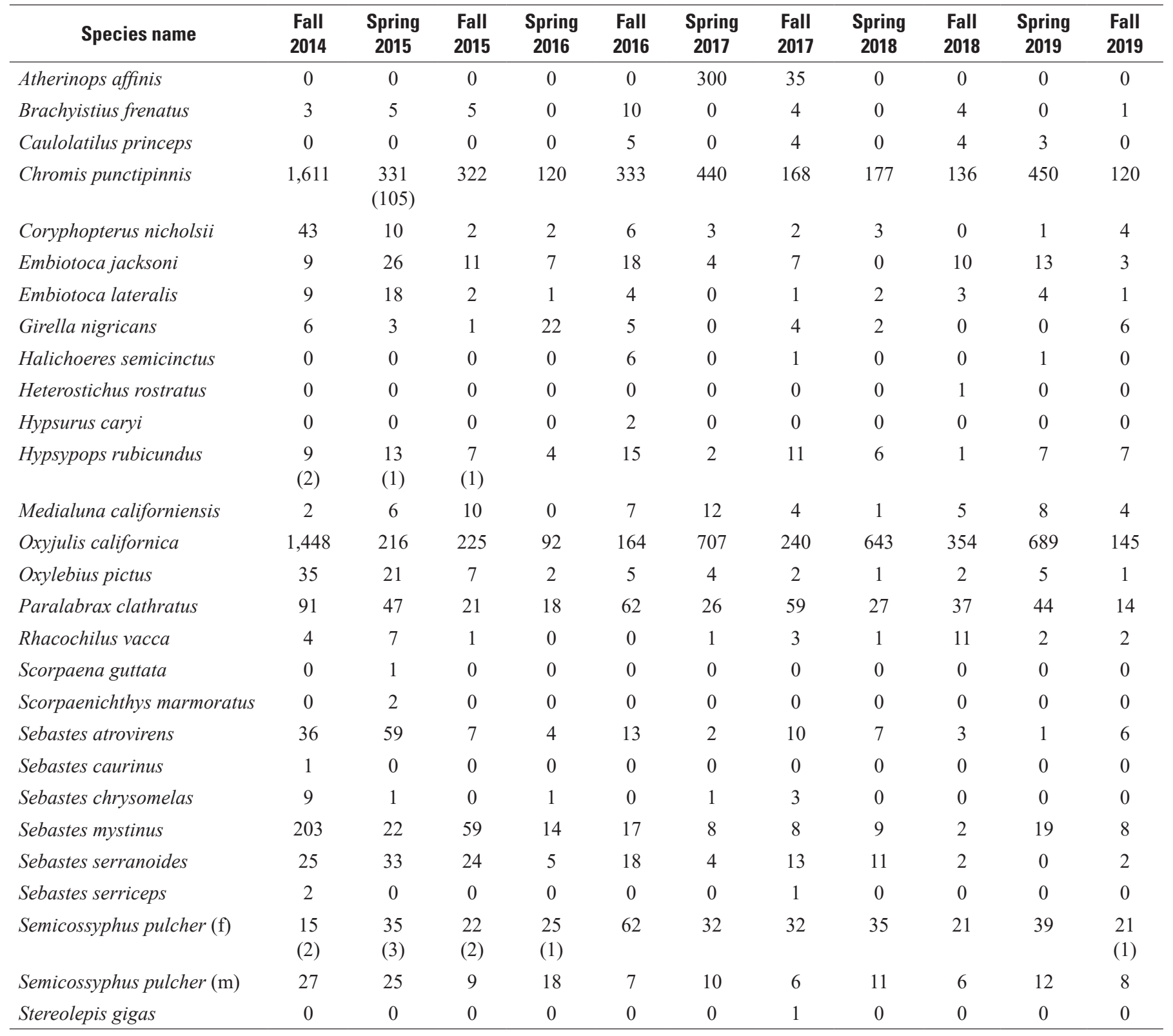



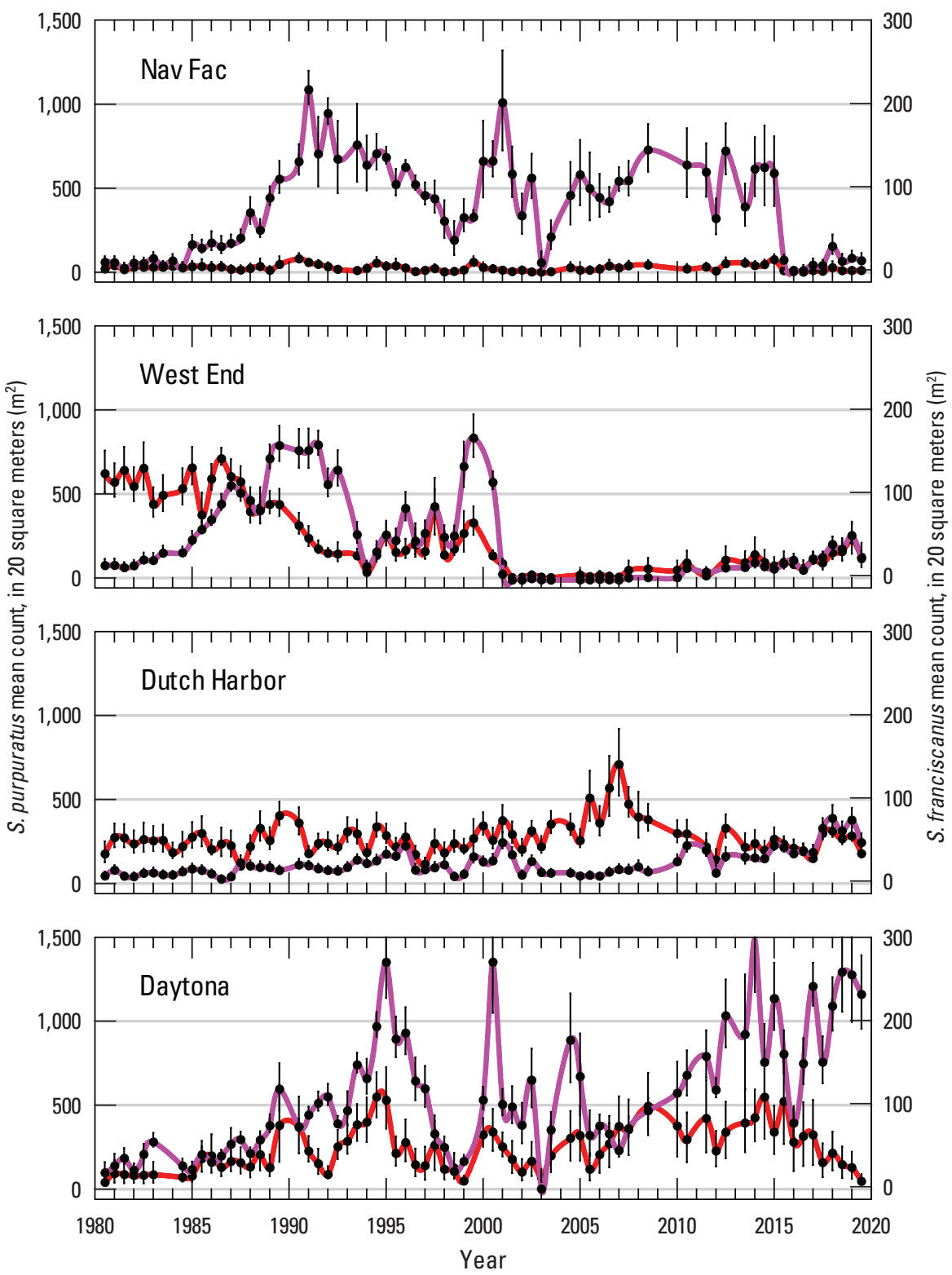

EXPLANATION

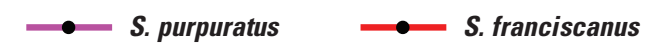

Figure 41. Long-term trends in red and purple sea urchin abundance. Swath means plus or minus 1 standard error (Only data from the original five transects at Nav Fac and Daytona are used to show long-term trends. Strongylocentrotus purpuratus and $S$. franciscanus are shown on different scales). 


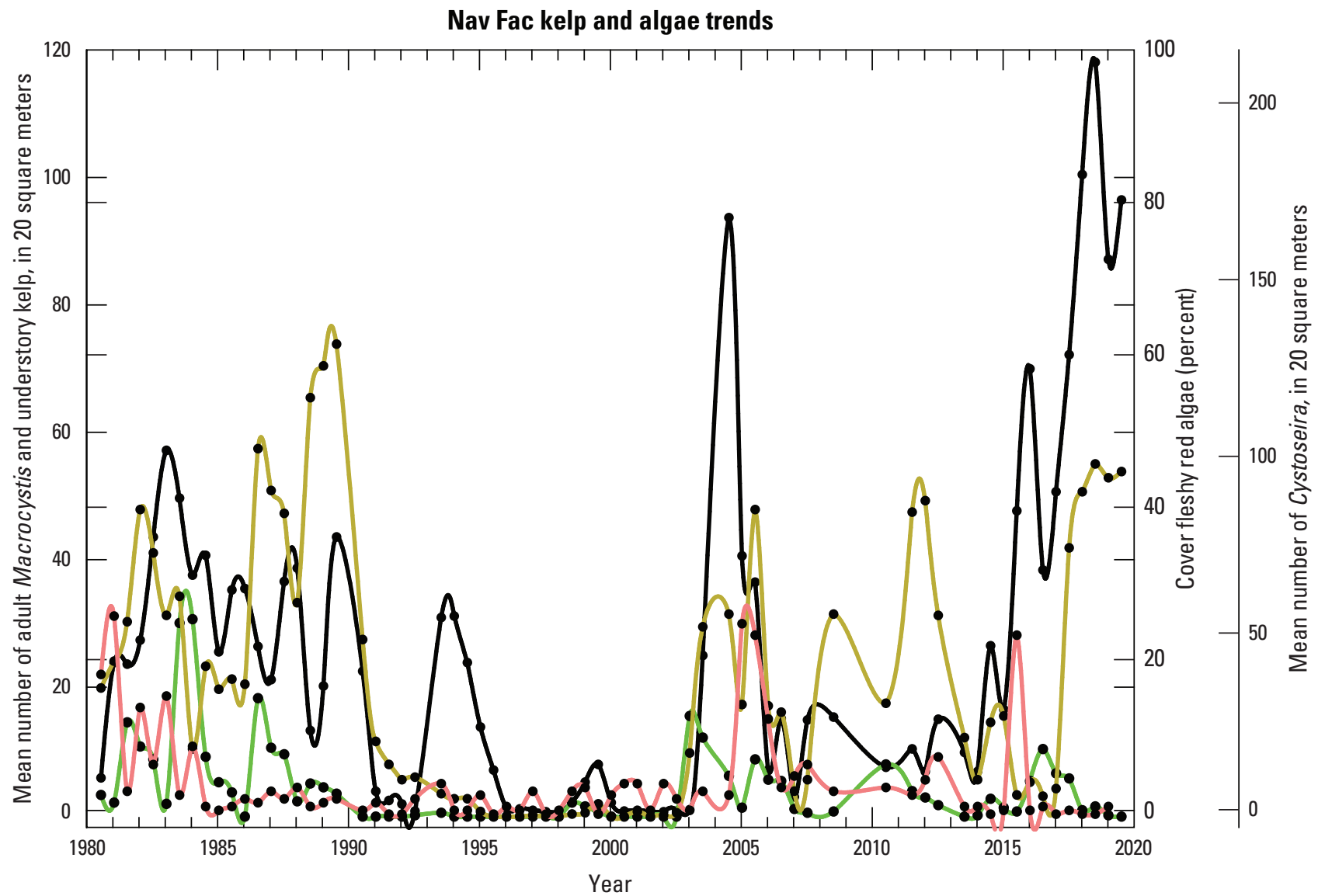

EXPLANATION

\section{$\longrightarrow$ Macrocystis $\longrightarrow$ Cystoseira $\quad \longrightarrow$ Understory kelp $\quad \bullet$ Fleshy red algae (percent cover)}

Figure 42. Macrocystis pyrifera (greater than 1 meter tall), understory kelp, and Cystoseira counts and fleshy red algae cover trends over time at Nav Fac (Only data from the original five transects are used to show long-term trends. Kelp and Cysteseira counts and cover of fleshy red algae shown on different axes). 


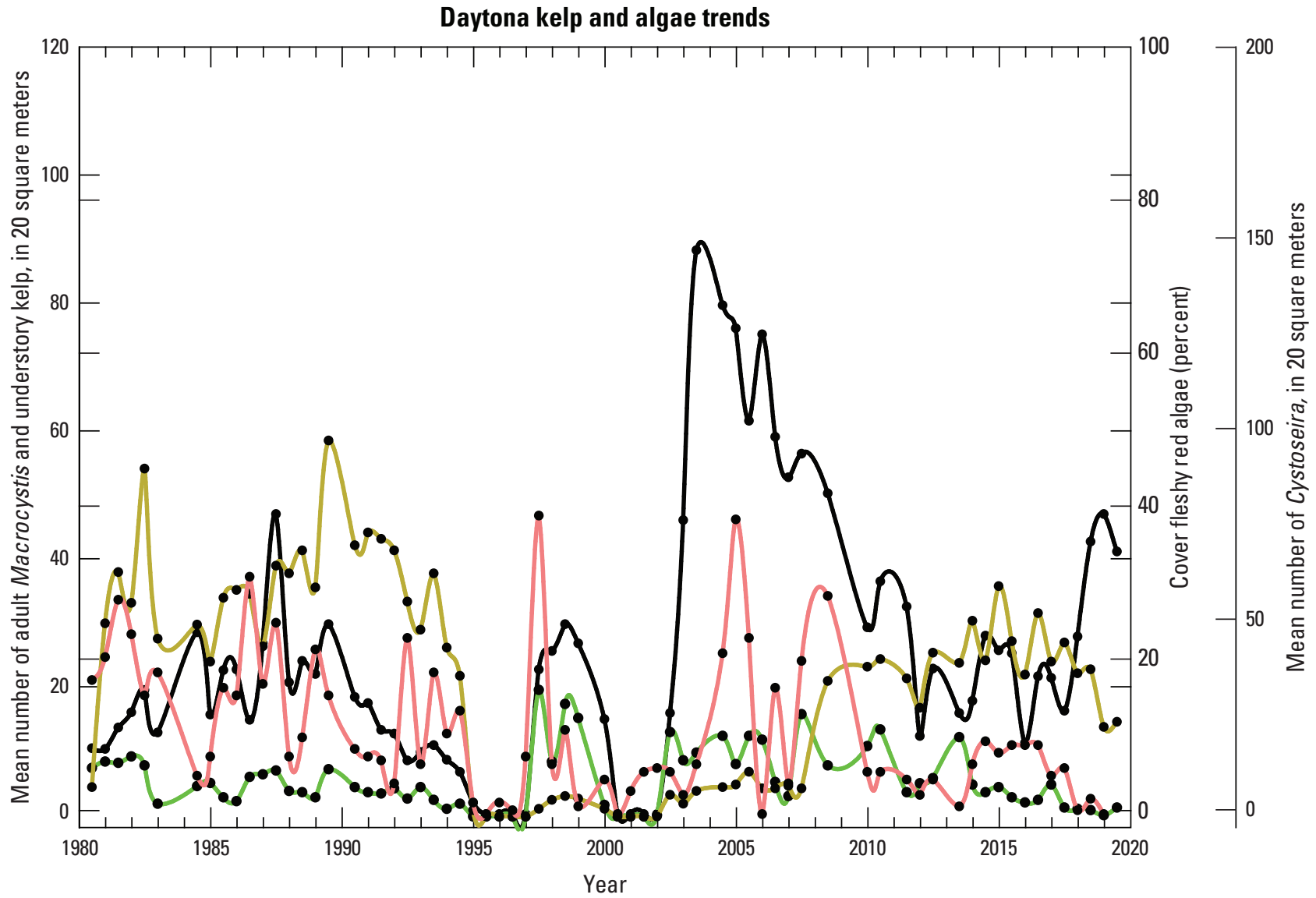

EXPLANATION

Figure 43. Macrocystis pyrifera (greater than 1 meter tall), understory kelp, and Cystoseira counts and fleshy red algae cover trends over time at Daytona (Only data from the original five transects are used to show long-term trends. Kelp and Cysteseira counts and cover of fleshy red algae shown on different axes). 


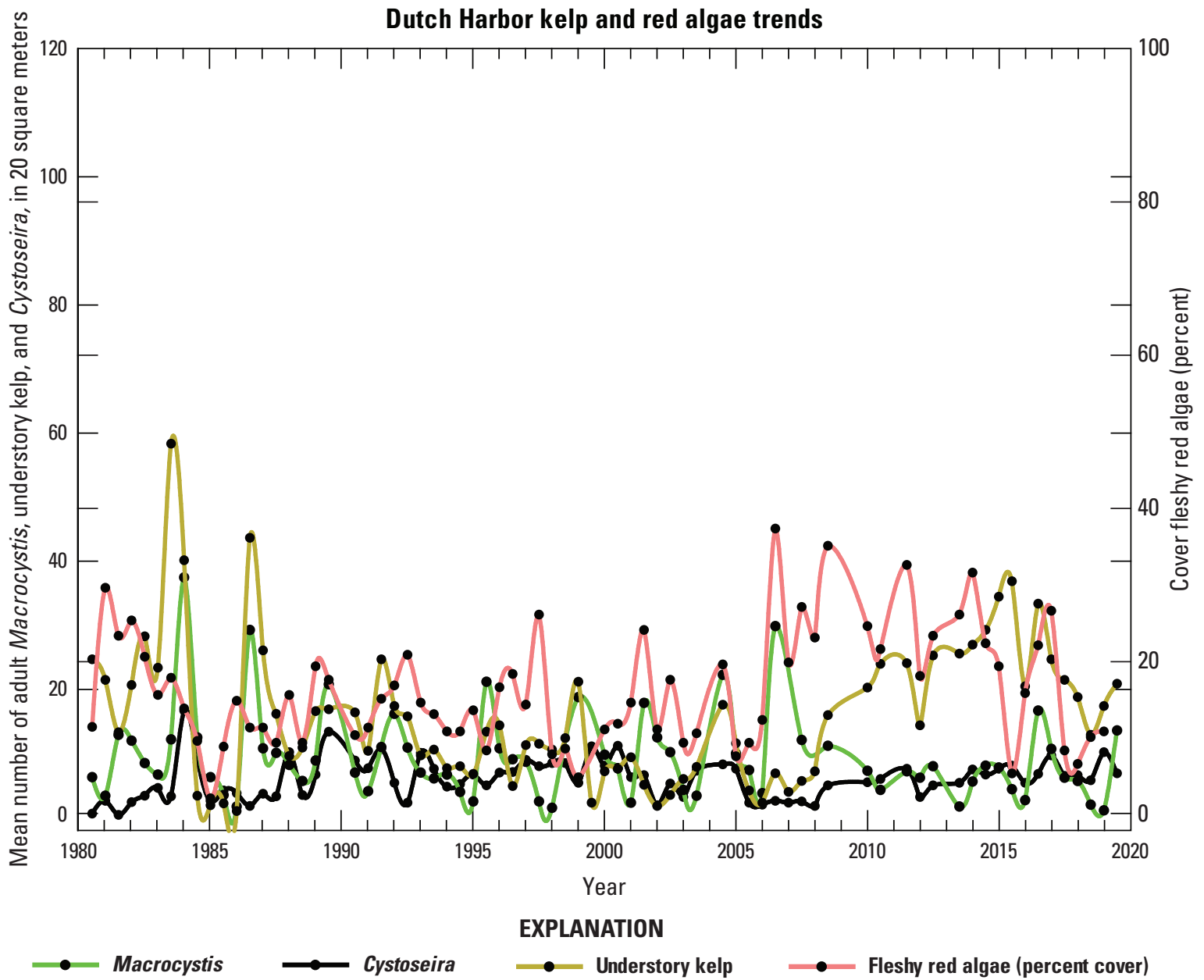

Figure 44. Macrocystis pyrifera (greater than 1 meter tall), understory kelp, and Cystoseira counts and fleshy red algae cover trends over time at Dutch Harbor (Cover of fleshy red algae shown on different axis). 


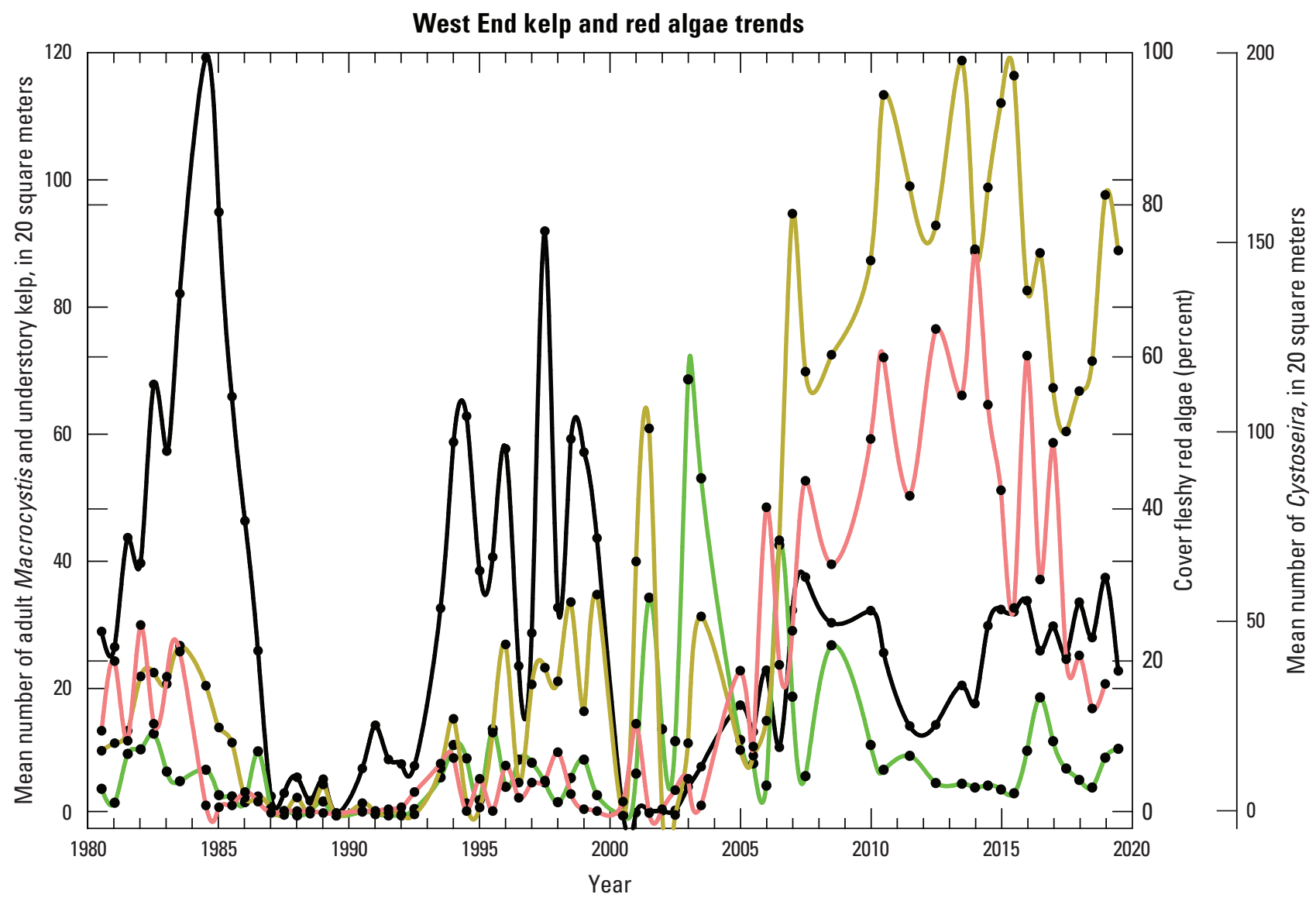

EXPLANATION

$\bullet$ Macrocystis $\longrightarrow$ Cystoseira $\quad \longrightarrow$ Understory kelp $\quad \bullet$ Fleshy red algae (percent cover)

Figure 45. Kelp (Macrocystis pyrifera greater than 1 meter tall and understory species) and fleshy red algae cover trends over time at West End (Kelp and Cysteseira counts and cover of fleshy red algae shown on different axes). 
Sea star wasting syndrome has devastated multiple species of sea stars along hundreds of miles of the Pacific coast of North America. Three asteroid species that were affected by the disease show very different histories of abundance over time at SNI. Pisaster giganteus, an important predator on snails, barnacles, and bivalves, shows a complex pattern of abundance with a few brief synchronous declines among the sites until 2014 when densities at all sites dropped simultaneously (fig. 46). A slight uptick in the abundance of this species was apparent at Daytona 100 in fall 2019. Pycnopodia helianthoides, a voracious predator on an assortment of invertebrate taxa, and the only sea star thought to have some potential for control of sea urchin populations in this system (Tegner and Dayton, 1981; Duggins, 1983), was not observed at our sites at SNI until the early 1990s. It is unknown whether it is a periodic member of the SNI nearshore community because of infrequent recruitment success or whether it was eliminated by a prior disease outbreak before sampling began in 1980. After appearing in 1991, it was frequently seen at low densities at all sites but most predictably at Dutch Harbor (fig. 47). In 2014, it disappeared from all sites and none have been observed since. Finally, $P$. miniata, which is a scavenger, experienced a large decline at all sites in the early 1980s, apparently, as a result of a disease event (fig. 48). This decline was not well synchronized among sites, however, lagging by 2 years or more between reductions observed at Nav Fac and other sites. Beginning in the early 1990s, it returned in moderate densities before eventually reaching higher numbers in the mid-2000s. It declined at all sites about 6 months later than the other two sea star species mentioned previously but has since returned to moderate densities like those seen in the 1990s.

Long-term changes in the densities of the herbivorous gastropod, $M$. undosa show interesting trends. Densities of M. undosa have mostly been substantially higher at Nav Fac than at other sites. Though there were several unsynchronized peaks and falls in abundance among the sites prior to 2002, all sites had minimal numbers of this snail between 2002 and 2015. The decline and subsequent low levels of this species suggests a catastrophic event occurred in 2001-02 (fig. 49); in fact, north facing beaches on SNI were littered with $M$. undosa shells in the early 2000s. Recovery began at Nav Fac in fall 2015 and somewhat later at the other sites. It could be that predation by sea stars was partly responsible for maintaining low densities of $M$. undosa and that the recovery of the snail was made possible by sea star declines.

\section{Conclusions and Management Considerations}

Despite negative trends observed elsewhere along the west coast of North America, kelp forests at San Nicolas Island (SNI) appear to have been fairly stable during the last few years. In an analysis of long-term data from around the world, Krumhansl and others (2016) concluded that kelp forests, in 38 percent of the ecoregions examined, were in decline. More recent data, following warm water anomalies and sea star declines that occurred in the northeastern Pacific in 2014-16 (Schultz and others, 2016; Harvell and others, 2019; Rogers-Bennett and Catton, 2019), have shown that sea urchin recruitment and loss of predators has led to urchin barrens in central and northern California and Oregon. The proliferation of sea urchins and resulting declines in kelp forests have been observed even in established sea otter areas like the Monterey Peninsula (Smith and others, 2021). This phenomenon has not been documented at long-term sites at SNI except for the legacy site, Sandy Cove (Kenner, unpub. data, 2020). Beas-Luna and others (2020) conducted a metaanalysis of several kelp forest monitoring programs from western North America and although long-term National Park Service and U.S. Geological Survey data from the California Channel Islands were not included, they concluded that the increase in sea urchins and resulting decline in kelp apparent to the north was not observed in the Southern California Bight during this period. Why southern California kelp forests were more resilient is unclear but may in part be due to the patchy nature of sea urchin recruitment and possibly the presence of non-asteroid urchin predators in the system, such as the spiny lobster, Panulirus interruptus, and sheephead, S. pulcher.

At SNI, there was a decline in the proportion of large $S$. franciscanus at all sites except Dutch Harbor during the last few years, and there was a decline in their density at Daytona 100. This trend was likely the result of sea otter foraging. Strongylocentrotus franciscanus are a preferred prey species of sea otters which, since their return to the island, have been concentrated primarily in the waters off the west end. In the last few years, sea otters have been more frequently observed at other parts of the island (Yee and others, 2020). It is likely that size selective foraging by sea otters has led to the shifting size proportions observed. Dutch Harbor, the only supersite where this shift was not observed, has abundant crevices where larger urchins may have found protection.

During the four decades we have monitored the subtidal sites around SNI, several El Niño events have battered the kelp beds with violent storms and subjected them to unusually warm water. Diseases have decimated sea star, abalone, and sea urchin populations at different times and at different scales around the island, sometimes resulting in dramatic localized community shifts. Fisheries for red sea urchins, spiny lobster, and some finfishes have exploited the area with unknown consequences. Sargassum horneri, an invasive brown alga that can seasonally dominate the algal community, 
became established at one of the sites. Sea otters, meanwhile, expanded in number and distribution, returning their considerable influence on the nearshore ecosystem to areas they had been absent from for more than a century.

The canceled survey trips in spring and fall 2020 represent missed opportunities in the long-term monitoring timeline. The cancellations are not unique, however. Prior to 2014, there were a few other survey trips missed due to weather, funding, or mechanical problems. In 2009, the spring and fall trips were cancelled. We cannot be certain what may have been missed during these gaps in the data record, but based on the data we have collected, we can conclude that most changes are gradual. Occasionally changes have been abrupt, such as the loss of sea urchins at the West End sites and their transition to a kelp dominated state, but such examples are rare.

Continued challenges to the nearshore rocky reef ecosystems appear certain in the coming years as new physical and biological changes affect the system. Warming seas, ocean acidification, rising sea level, and more violent storms are likely, in addition to new invasive species and disease outbreaks. Sea otters also will have dramatic direct and indirect effects on community structure and composition as the island population grows toward carrying capacity.

Each of the SNI sites we monitor have their own character resulting from such physical factors as wave exposure, bottom relief and substrate hardness, as well as site-specific stochastic ecological history. It is only through long-term studies such as this that we can gain an appreciation for what is an expected response to disturbance and what changes could be cause for concern. Thus, continued monitoring of this system represents an opportunity to build a real understanding of the factors that drive ecosystem dynamics around SNI, to understand the role of top predators in ecosystem functionality, and to elucidate the ecosystem components that create resiliency to new and emerging threats.

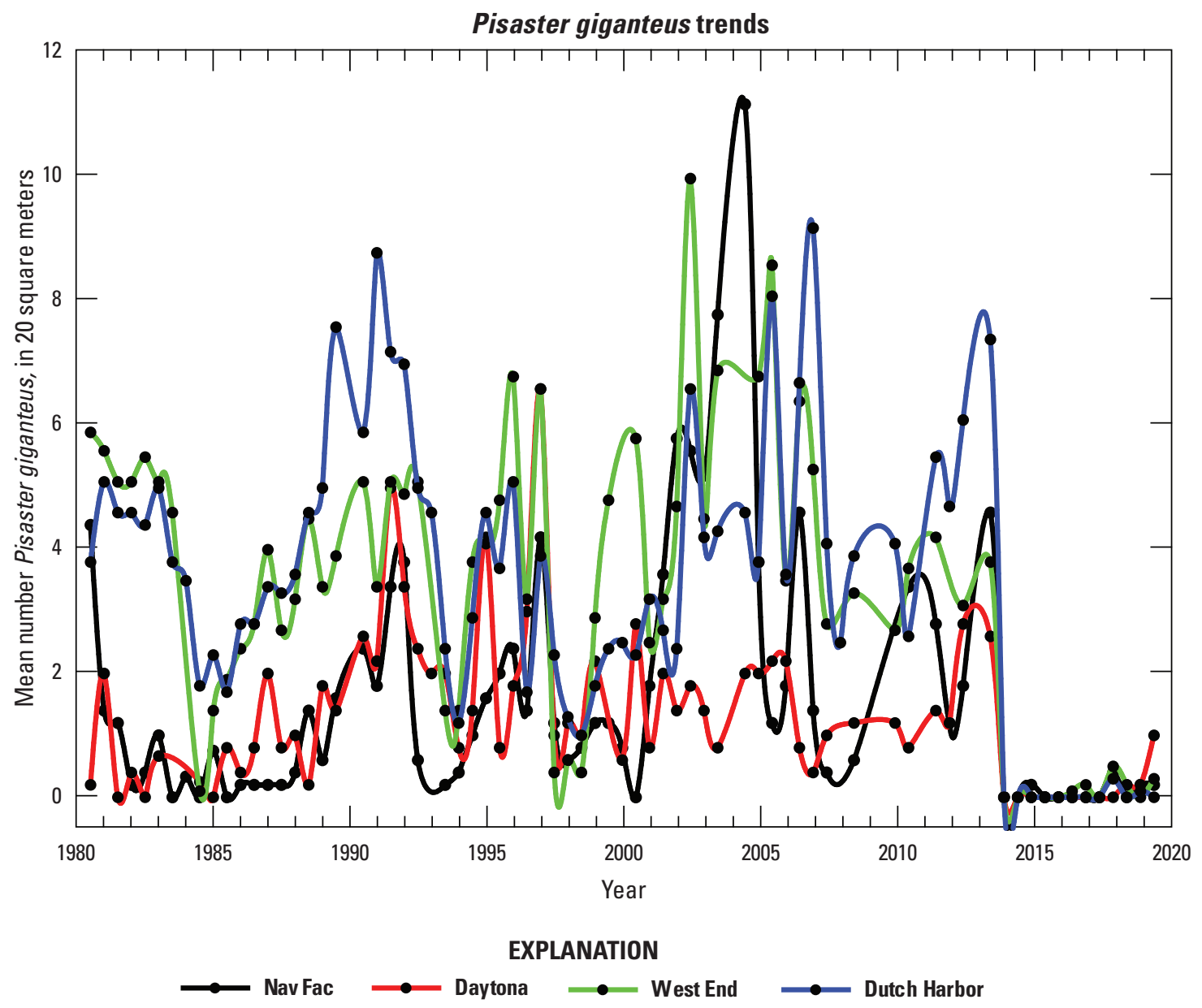

Figure 46. Pisaster giganteus trends over time at West End, Dutch Harbor, and the original five swaths of Nav Fac and Daytona from fall 1980 to fall 2019. 


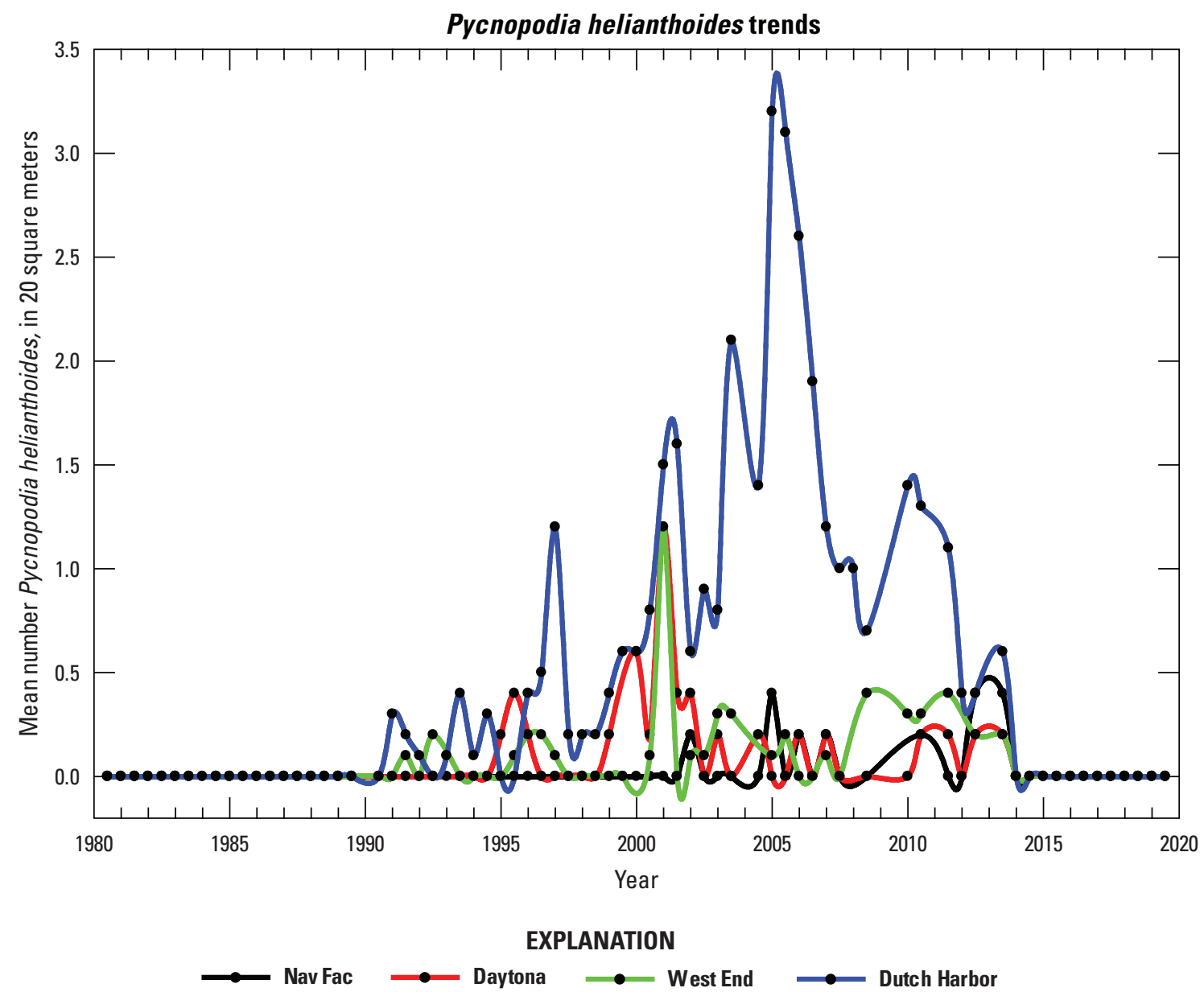

Figure 47. Pycnopodia helianthoides trends over time at West End, Dutch Harbor, and the original five swaths of Nav Fac and Daytona from fall 1980 to fall 2019. 


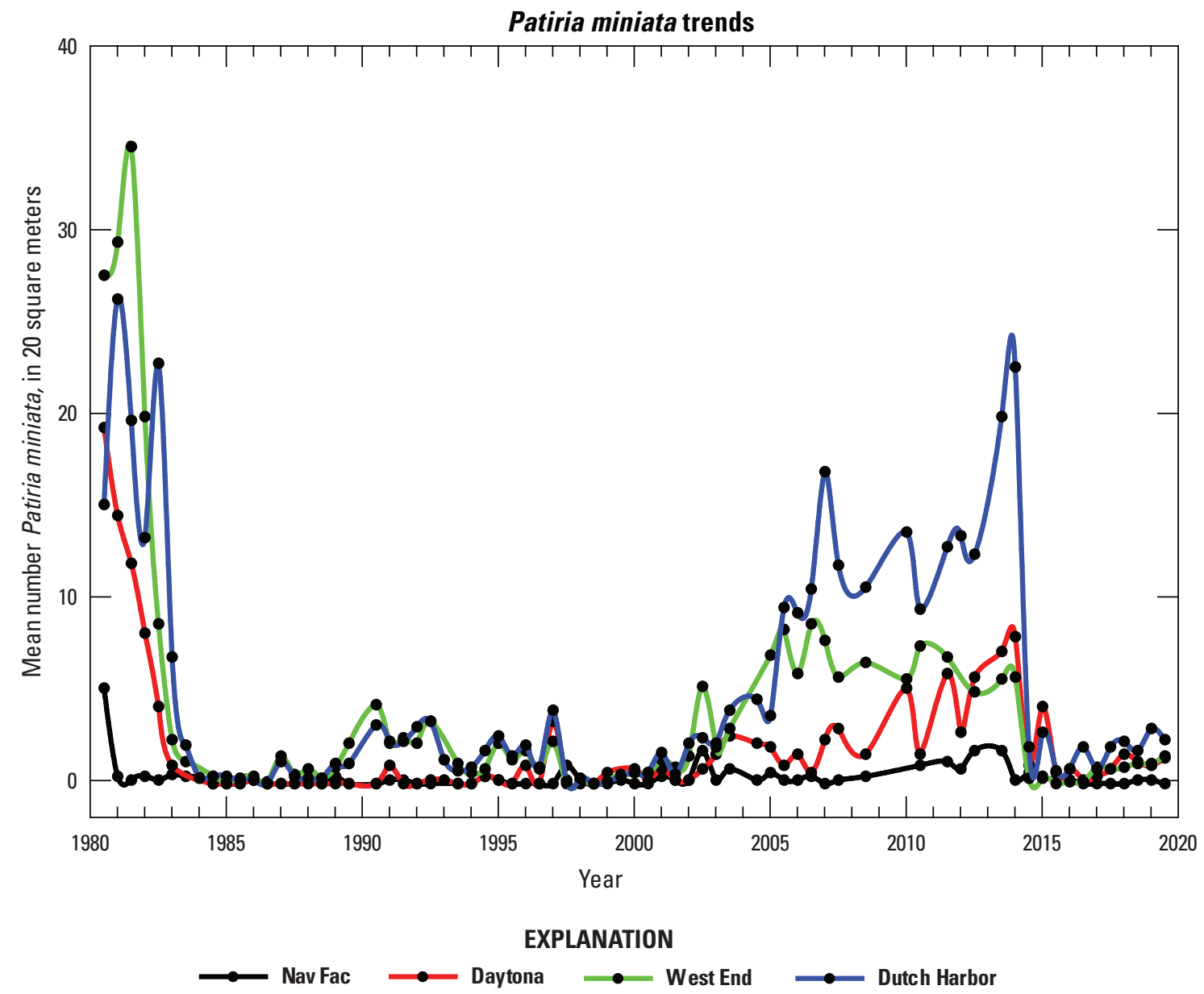

Figure 48. Patiria miniata trends over time at West End, Dutch Harbor, and the original five swaths of Nav Fac and Daytona from fall 1980 to fall 2019. 


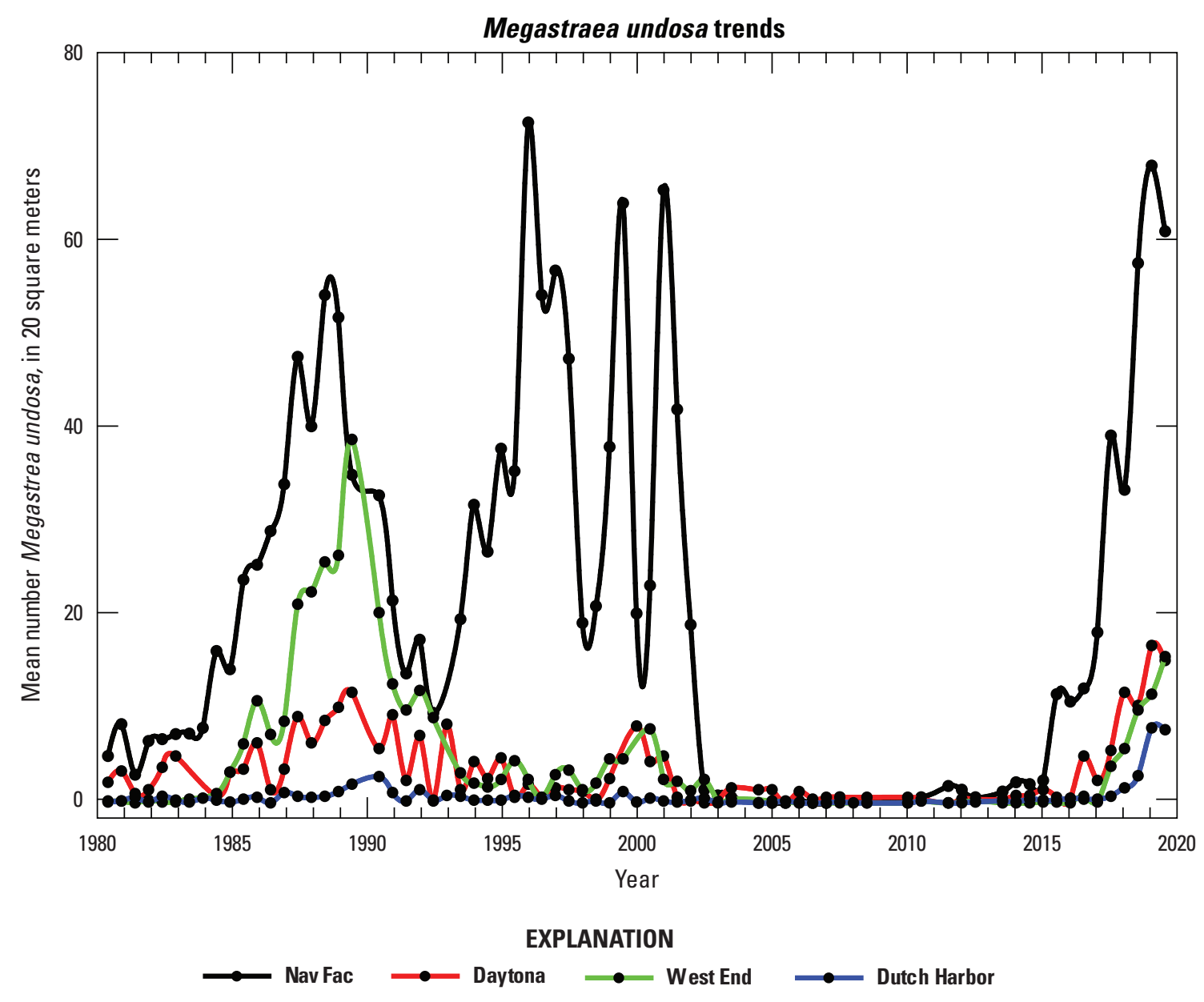

Figure 49. Megastaea undosa trends over time at West End, Dutch Harbor, and the original five swaths of Nav Fac and Daytona from fall 1980 to fall 2019. 


\section{References Cited}

Abbott, I.A., and Hollenberg, G.J., 1976, Marine algae of California: Stanford, Calif., Stanford University Press, 844 p.

Beas-Luna, R., Micheli, F., Woodson, C.B., Carr, M., Malone, D., Torre, J., Boch, C., Caselle, J.E., Edwards, M., Freiwald, J., Hamilton, S.L., Hernandez, A., Konar, B., Kroeker, K.J., Lorda, J., Montaño-Moctezuma, G., and TorresMoye, G., 2020, Geographic variation in responses of kelp forest communities of the California Current to recent climatic changes: Global Change Biology, v. 26, no. 11, p. 6457-6473, https://doi.org/10.1111/gcb.15273.

Carswell, L.P., Speckman, S.G., and Gill, V.A., 2015, Shellfish fishery conflicts and perceptions of sea otters in California and Alaska, chap. 12 of Larson, S.E., Bodkin, J.L., and VanBlaricom, G.R., eds., Sea otter conservation: Boston, Academic Press, p. 333-368, https://doi.org/10.1016/B978-012-801402-8.00012-3.

Cowen, R.K., 1985, Large scale pattern of recruitment by the labrid, Semicossyphus pulcher-Causes and implications: Journal of Marine Research, v. 43, no. 3, p. 719-742, https://doi.org/10.1357/002224085788440376.

Cowen, R.K., 1990, Sex change and life history patterns of the labrid, Semicossyphus pulcher, across an environmental gradient: Copeia, v. 3, p. 787-795, https://doi.org/ $10.2307 / 1446444$.

Dayton, P.K., 1985, Ecology of kelp communities-Annual Review of Ecology and Systematics: Scripps Institution of Oceanography, v. 16, no. 1, p. 215-245, https://doi.org/ 10.1146/annurev.es.16.110185.001243.

Dayton, P.K., Tegner, M.J., Edwards, P.B., and Riser, K.L., 1998, Sliding baselines, ghosts, and reduced expectations in kelp forest communities: Ecological Applications, v. 8, no. 2, p. 309-322, https://doi.org/10.1890/1051-0761(1998)008 [0309:SBGARE]2.0.CO;2.

Duggins, D.O., 1983, Starfish predation and the creation of mosaic patterns in a kelp-dominated community: Ecology, v. 64, no. 6, p. 1610-1619, https://doi.org/10.2307/1937514.

Duggins, D.O., Simenstad, C.A., and Estes, J.A., 1989, Magnification of secondary production by kelp detritus in coastal marine ecosystems: Science, v. 245, no. 4914, p. 170-173, https://doi.org/10.1126/science.245.4914.170.

Ebert, T.A., 1968, Growth rates of the sea urchin Strongylocentrotus purpuratus related to food availability and spine abrasion: Ecology, v. 49, no. 6, p. 1075-1091, https://doi.org/10.2307/1934491.

Ebert, T.A., 1977, An experimental analysis of sea urchin dynamics and community interactions on a rock jetty: Journal of Experimental Marine Biology and Ecology, v. 27, no. 1, p. 1-22, https://doi.org/10.1016/0022-0981(77)90050-8.
Ebert, T.A., and Russell, M.P., 1992, Growth and mortality estimates for red sea urchin Strongylocentrotus franciscanus from San Nicolas Island, California: Marine Ecology Progress Series, v. 81, no. 1, p. 31-41, https://doi.org/ 10.3354/meps081031.

Estes, J.A., and Duggins, D.O., 1995, Sea otters and kelp forests in Alaska - Generality and variation in a community ecological paradigm: Ecological Monographs, v. 65, no. 1, p. 75-100, https://doi.org/10.2307/2937159.

Harrold, C., and Pearse, J.S., 1987, The ecological role of echinoderms in kelp forests, in Jangoux, M., and Lawrence, J.M., eds., Echinoderm studies v. 2: CRC Press, p. 137-233.

Harrold, C., and Reed, D.C., 1985, Food availability, sea urchin grazing, and kelp forest community structure: Ecology, v. 66, no. 4, p. 1160-1169, https://doi.org/10.2307/1939168.

Harvell, C.D., Montecino-Latorre, D., Caldwell, J.M., Burt, J.M., Bosley, K., Keller, A., Heron, S.F., Salomon, A.K., Lee, L., Pontier, O., Pattengill-Semmens, C., and Gaydos, J.K., 2019, Disease epidemic and a marine heat wave are associated with the continental-scale collapse of a pivotal predator (Pycnopodia helianthoides): Science Advances, v. 5, no. 1, 8 p., https://doi.org/10.1126/sciadv.aau7042.

Kenner, M.C., 1992, Population dynamics of the sea urchin Strongylocentrotus purpuratus in a Central California kelp forest-Recruitment, mortality, growth, and diet: Marine Biology, v. 112, no. 1, p. 107-118, https://doi.org/10.1007/ BF00349734.

Kenner, M.C., 2016, Kelp forest monitoring at Naval Base Ventura County, San Nicolas Island, CA fall 2015 and spring 2016-Second Annual Report. A report to the US Navy: Santa Cruz, Calif., University of California, 68 p.

Kenner, M.C., and Tinker, M.T., 2018, Stability and change in kelp forest habitats at San Nicolas Island: Western North American Naturalist, v. 78, no. 4, p. 633-643, https://doi.org/ 10.3398/064.078.0407.

Krumhans1, K.A., Okamoto, D.K., Rassweiler, A., Novak, M., Bolton, J.J., Cavanaugh, K.C., Connell, S.D., Johnson, C.R., Konar, B., Ling, S.D., Micheli, F., Norderhaug, K.M., Pérez-Matus, A., Sousa-Pinto, I., Reed, D.C., Salomon, A.K., Shears, N.T., Wernberg, T., Anderson, R.J., Barrett, N.S., Buschmann, A.H., Carr, M.H., Caselle, J.E., Derrien-Courtel, S., Edgar, G.J., Edwards, M., Estes, J.A., Goodwin, C., Kenner, M.C., Kushner, D.J., Moy, F.E., Nunn, J., Steneck, R.S., Vásquez, J., Watson, J., Witman, J.D., and Byrnes, J.E.K., 2016, Global patterns of kelp forest change over the past half-century: Proceedings of the National Academy of Sciences of the United States of America, v. 113, no. 48, p. 13785-13790, https://doi.org/10.1073/pnas.1606102113.

Lafferty, K.D., 2004, Fishing for lobsters indirectly increases epidemics in sea urchins: Ecological Applications, v. 14, no. 5, p. 1566-1573, https://doi.org/10.1890/03-5088. 
Marks, L.M., Salinas-Ruiz, P., Reed, D.C., Holbrook, S.J., Culver, C.S., Engle, J.M., Kushner, D.J., Caselle, J.E., Freiwald, J., Williams, J.P., Smith, J.R., Aguilar-Rosas, L.E., and Kaplanis, N.J., 2015, Range expansion of a non-native, invasive macroalga Sargassum horneri (Turner) C. Agardh, 1820 in the eastern Pacific: BioInvasions Records, v. 4, no. 4, p. 243-248, https://doi.org/10.3391/bir.2015.4.4.02.

Miller, K.A., Engle, J.M., Uwai, S., and Kawai, H., 2007, First report of the Asian seaweed Sargassum filicinum Harvey (Fucales) in California, USA: Biological Invasions, v. 9, no. 5, p. 609-613, https://doi.org/10.1007/s10530006-9060-2.

Miller, R.J., Lafferty, K.D., Lamy, T., Kui, L., Rassweiler, A., and Reed, D.C., 2018, Giant kelp, Macrocystis pyrifera, increases faunal diversity through physical engineering: The Royal Society, v. 285, no. 1874, 8 p., https://doi.org/10.1098/ rspb.2017.2571.

Rogers-Bennett, L., and Catton, C.A., 2019, Marine heat wave and multiple stressors tip bull kelp forest to sea urchin barrens: Scientific Reports, v. 9, no. 15050, p. 1-9, https://doi.org/10.1038/s41598-019-51114-y.

Rogers-Bennett, L., Haaker, P.L., Huff, T.O., and Dayton, P.K., 2002, Estimating baseline abundances of abalone in California for restoration: California Cooperative Oceanic Fisheries Investigations Reports, v. 43, p. 97-111.

Russell, M.P., 1987, Life history traits and resource allocation in the purple sea urchin Strongylocentrotus purpuratus (Stimpson): Journal of Experimental Marine Biology and Ecology, v. 108, no. 3, p. 199-216, https://doi.org/10.1016/ 0022-0981(87)90085-2.

Schiel, D.R., and Foster, M.S., 2015, The biology and ecology of giant kelp forests: Oakland, Calif., USA, University of California Press, 416 p., https://doi.org/10.1525/california/97 80520278868.001.0001.

Schultz, J.A., Cloutier, R.N., and Côté, I.M., 2016, Evidence for a trophic cascade on rocky reefs following sea star mass mortality in British Columbia: Peer J Life \& Environment, https://doi.org/10.7717/peerj.1980.

Smith, J.G., Tomoleoni, J., Staedler, M., Lyon, S., Fujii, J., and Tinker, M.T., 2021, Behavioral responses across a mosaic of ecosystem states restructure a sea otter-urchin trophic cascade: Proceedings of the National Academy of Sciences v. 118, no. 11, 7 p., https://doi.org/10.1073/pnas.2012493118.

Steneck, R.S., Graham, M.H., Bourque, B.J., Corbett, D., Erlandson, J.M., Estes, J.A., and Tegner, M.J., 2002, Kelp forest ecosystems-Biodiversity, stability, resilience and future: Environmental Conservation, v. 29, no. 4, p. 436-459, https://doi.org/10.1017/S0376892902000322.
Sullaway, G.H., and Edwards, M.S., 2020, Impacts of the non-native alga Sargassum horneri on benthic community production in a California kelp forest: Marine Ecology Progress Series, v. 637, p. 45-57, https://doi.org/10.3354/ meps13231.

Tegner, M.J., and Dayton, P.K., 1981, Population structure, recruitment and mortality of two sea urchins (Strongylocentrotus franciscanus and S. purpuratus) in a kelp forest: Marine Ecology Progress Series, v. 5, no. 3, p. 255-268, https://doi.org/10.3354/meps005255.

Tegner, M.J., and Dayton, P.K., 1991, Sea urchins, El Niños, and the long term stability of Southern California kelp forest communities: Marine Ecology Progress Series, v. 77, no. 1, p. 49-63, https://doi.org/10.3354/meps077049.

U.S. Navy, 2015, Integrated natural resources management plan for Naval Base Ventura County, San Nicolas Island, California: U.S. Navy, December 2010, updated December 2015.

U.S. Fish and Wildlife Service, 2012, Final supplemental environmental impact statement on the translocation of southern sea otters: Ventura, Calif., Ventura Fish and Wildlife Office, $348 \mathrm{p}$.

VanBlaricom, G.R., Ruediger, J.L., Friedman, C.S., Woodard, D.D., and Hedrick, R.P., 1993, Discovery of withering syndrome among black abalone Haliotis cracherodii leach, 1814, populations at San Nicolas Island, California: Journal of Shellfish Research, v. 12, no. 2, p. 185-188.

Wilmers, C.C., Estes, J.A., Edwards, M., Laidre, K.L., and Konar, B., 2012, Do trophic cascades affect the storage and flux of atmospheric carbon? An analysis of sea otters and kelp forests: Frontiers in Ecology and the Environment, v. 10, no. 8, p. 409-415, https://doi.org/10.1890/110176.

Yee, J.L., Tomoleoni, J.A., Kenner, M.C., Fujii, J., Bentall, G.B., Tinker, M.T., and Hatfield, B.B., 2020, Southern (California) sea otter population status and trends at San Nicolas Island, 2017-2020: U.S. Geological Survey OpenFile Report 2020-1115, 38 p., https://doi.org/10.3133/ ofr20201115. 


\section{Appendix 1. Sampling History}

In 1980, in anticipation of the translocation of sea otters to San Nicolas Island (SNI), U.S. Fish and Wildlife Service biologists, in cooperation with University of California Santa Cruz, established the SNI Subtidal Baseline project, a kelp forest monitoring program with the intention of documenting resulting ecosystem changes at the island (Kenner and others, 2013). Six permanent sites were initially installed: Nav Fac, West End Urchin, West End Kelp, West Dutch Harbor, East Dutch Harbor, and Daytona Beach. A seventh site, Sandy Cove, was added in 1986. At these sites, kelps and a suite of motile macroinvertebrates were counted on fixed transects, the amount of exposed substrate and the cover of algae and sessile invertebrates were measured at fixed locations, and midwater and benthic fish were counted on transects. Responsibility for monitoring the sites was given to the U.S. Geological Survey (USGS) in 1996. The sites have been monitored twice annually in spring and fall, with a few exceptions, since their inception.

In 2014, the U.S. Navy contracted with the USGS to monitor the biota of four rocky reef sites around SNI (fig. 1 in the main body of the report). The purpose of this project was to continue to expand the 33-year dataset of subtidal monitoring at SNI but with modifications to the protocols so that these data were comparable with those from the other Channel Islands. To achieve this, the six original USGS sites were expanded or combined, and a few changes were made to data collection, including the addition of some invertebrates to the transect counts and the collection of size data on fish and some invertebrates. This project allows installation managers to characterize the long-term status and trends of communities and populations that occur within SNI's rocky reef and kelp forest habitat and their importance in the ecology of the Channel Islands. This perspective also will help them to understand the potential effects of future perturbations such as disease events or changing environmental conditions.
The original sites consisted of a 50-meter (m) main transect with five $10-\mathrm{m}$ by $2-\mathrm{m}$ benthic band transects (swaths), ten 1-square meter $\left(\mathrm{m}^{2}\right)$ random point contact (RPC) quadrats and five 50-m fish transects. For better comparability to kelp forest monitoring conducted at other Channel Islands, four of the sites were expanded to twice their original size. With the goal to retain compatibility with more than three decades of previously collected data, the four new "supersites" were expanded to consist of a main transect with two 50-m subsections, each with the associated five swaths and ten RPC quadrats. The West End supersite was created by combining the West End Urchin and West End Kelp sites, which were already physically connected. The Dutch Harbor supersite was created by combining the East Dutch Harbor and West Dutch Harbor sites, which were about $140 \mathrm{~m}$ apart and roughly paralleled each other on two lobes of a reef separated by a sand channel. Nav Fac 100 and Daytona 100 were created by adding new segments to the existing Nav Fac and Daytona sites. Except in the case of Dutch Harbor, where these segments are on adjacent reefs, the 50-m main transects are connected in a linear fashion with the $50-\mathrm{m}$ end of one connecting to the $0-\mathrm{m}$ end of the other.

The expansion of sites for this project did not include additional fish transects. Therefore, because the supersites at West End and Dutch Harbor were formed by combining existing sites, they each have 10 fish transects, whereas Nav Fac 100 and Daytona 100 each have only 5 fish transects.

\section{References Cited}

Kenner, M.C., Estes, J.A., Tinker, M.T., Bodkin, J.L., Cowen, R.K., Harrold, C., Hatfield, B.B., Novak, M., Rassweiler, A., and Reed, D.C., 2013, A multi-decade time series of kelp forest community structure at San Nicolas Island, California (USA): Ecology, v. 94, no. 11, p. 2654, https://doi.org/10.1890/13-0561R.1. 
For more information concerning the research in this report, contact the

Director, Western Ecological Research Center

U.S. Geological Survey

3020 State University Drive East

Sacramento, California 95819

https://www.usgs.gov/centers/werc

Publishing support provided by the U.S. Geological Survey

Science Publishing Network, Sacramento Publishing Service Center 
